\title{
THE SWAMP DARTERS OF THE SUBGENUS HOLOLEPIS (PISCES, PERCIDAE)
}

\author{
BRUCE B. COLLETTE, \\ Ichthyological Laboratory, Fish and Wildlife Service, \\ U.S. National Museum, W ashington 25, D. C,
}

\section{INTRODUCTION}

The object of this paper is to clarify the relationships within and among the darters of the subgenus Hololepis, genus Etheostoma.

Hubbs and Cannon (1935) thoroughly reviewed the darters of the nominal genera Hololepis and Villora on the basis of the specimens then available. Extensive collecting in recent years has greatly increased available material and necessitates a modification of some of their conclusions.

Bailey (1951), in Bailey, Winn, and Smith, 1954; and in Bailey and Gosline, 1955 reduced the many nominal genera of darters to three. These are Percina, Ammocrypta, and Etheostoma. He based this decision on "evidence that the characters employed to define and delimit the groups... are highly variable both intraspecifically and interspecifically, are subject to complete overlap from group to group, and are commonly the product of convergent evolution" (Bailey, Winn, and Smith, 1954, page 141). Bailey utilized some of the former genera as subgenera (Bailey and Gosline, 1955: Fig. $1)$. Although it would be better to have data published before nomenclatorial changes are made, I will follow his use of the name Hololepis as a subgenus of Etheostoma. However, I can not agree with his implication that the subgenus Villora Hubbs and Cannon be made a synonym of Hololepis (See Collette and Yerger, 1962). Upon replacing Etheostoma edwini in the subgenus Villora, the subgenus Hololepis constitutes a group of eight forms of small specialized swamp darters. Four of these forms are found in the swamps, lakes, and backwaters of the Coastal Plain, one in the lowlands of the Mississippi Basin, and the other three are limited to the backwaters of Piedmont streams along the Atlantic Coast.

\section{ACKNOWLEDGMENTS}

This study was begun at the suggestion of Edward C. Raney and completed under his guidance in partial fulfillment of the requirements for the degree of Doctor of
Philosophy at Cornell University. In addition to his constant interest, Dr. Raney provided support through National Science Foundation Grants 2893 and 9038.

The section on pored lateral-line scales in Etheostoma fusiforme was submitted as a minor problem in limnology to Clifford O. Berg to whom I express my appreciation for his comments and interest. The New York State Museum and Science Service provided support for field work on the Long Island populations of E. fusiforme through a Graduate Student Honorarium.

This study could not have been satisfactorily completed without the use of specimens from a number of museums and universities. Appreciation is expressed to the following persons and their institutions for having loaned specimens under their care and for making facilities at their institutions available: Joseph R. Bailey, Duke University (DU); Reeve M. Bailey, University of Michigan Museum of Zoology (UMMZ); James E. Böhlke, Academy of Natural Sciences of Philadelphia (ANSP); Frank B. Cross, Museum of Natural History, University of Kansas (KU); Harry W. Freeman, University of South Carolina (specimens transferred to Cornell University); Shelby D. Gerking, University of Indiana (UI); Robert H. Gibbs, Jr., Boston University (BU); A. Frederick Hemphill, Spring Hill College, Alabama (UAIC); Clark Hubbs, University of Texas (TNHC); Robert H. Kanazawa, Ernest A. Lachner, Leonard P. Schultz and W. Ralph Taylor, Fish Division, United States National Museum (USNM); Y. J. McGaha, University of Mississippi (UM); Romeo Mansueti, Maryland Department of Research and Education (M); George A. Moore, Oklahoma State University (OAM); E. E. Prather, Alabama Polytechnic Institute (API); Edward C. Raney, Cornell University (CU); C. Richard Robins, University of Miami Marine Laboratory (UMML); Donald C. Scott, University of Georgia (UG); Philip W. Smith, Illinois Natural History Survey 
(INHS); Royal D. Suttkus, Tulane University (TU); Ralph M. Wetzel, University of Connecticut (UCF); William S. Woolcott, University of Richmond (UR); Ralph W. Yerger, Florida State University (FSU); Museum of Comparative Zoology, Harvard University (MCZ); New York State Museum (NYSM); and the Florida State Museum, University of Florida (UF).

I am also indebted to the following individuals who assisted me in collecting Hololepis: Benjamin Bouck, Sara E. Collette, William P. Davis, Robert W. Ficken, Harvey Fischer, Oliver S. Flint, Neal R. Foster, Thomas H. Frazzetta, Frederick R. Gehlbach, Robert H. Gibbs, Jr., Theodore O. Hendrickson, Harold H. Howard, Darrell E. Louder, William A. Lund, Robert V. Miller, Rudolph J. Miller, Edmund Morgan, Herman Mueller, Thomas L. Poulson, John S. Ramsey, Robert Risebrough, Thomas Savage, Lester L. Short, Jr., Fred Sibley, Royal D. Suttkus, John Swineford, and John S. Willis.

Darrell E. Louder, North Carolina Wildlife Resources Commission, has aided immeasurably by collecting specimens of $E$. fusiforme fusiforme from the North Carolina Bay Lakes for me. Daniel M. Cohen, Robert H. Gibbs, Jr., Ernest A. Lachner, William A. Lund, and Royal D. Suttkus have made many valuable suggestions. Rudolph J. Miller kindly drew the figures of the genital papillae and the distribution of the breeding tubercles (Fig. 1). Douglass M. Payne made the photographs. Sara E. Collette typed several early drafts of the paper and Alice B. Holland typed the final draft.

\section{Characters STUdied AND Their SignificANCE}

Counts were made in accordance with the methods outlined by Hubbs and Lagler (1947, 1958) and Hubbs and Cannon (1935) except as modified below. Each group of characters will be discussed to give my interpretation of their relative value in this study.

Lateral-line scales: The total number of lateral-line scales was valuable in distinguishing some species and also in separating races of E. serriferum. The number of pored lateral-line scales was especially valuable in the recognition of subspecies of $E$. fusiforme. However, it is subject to develop- mental variation which made its use somewhat complicated as discussed under development and geographic variation in $E$. fusiforme. The number of unpored lateralline scales was not studied separately because it is merely an expression of the same factors represented by the total and pored lateralline scales. Hubbs and Cannon (1935), Bailey (1950), and Bailey and Frey (1951) used the ratio of pored to unpored lateralline scales. The value of this ratio is negated by the extreme variation of the pored lateralline scales in E. fusiforme. In the other species it merely reflected the number of pored scales and therefore seemed unnecessary.

Scale rows above and below the lateral line: This character was of value in studying the neotenic populations of E. fusiforme and is further discussed under geographic variation in E. fusiforme. The two species of the subgenus Villora have fewer scales below the lateral line than the species of the subgenus Hololepis, since the scales are generally larger in Villora. E. serriferum has more scales both above and below the lateral line than the other species of the subgenus Hololepis.

Fin Rays: The number of first dorsal spines and second dorsal rays was of little taxonomic value. The high number of spines and rays in E. serriferum is an indication of its relatively primitive position in the subgenus Hololepis. Several populations of E. fusiforme, including the Nantucket population named as fusiforme insulae by Hubbs and Cannon (1935), had abnormally low dorsal spine counts. The low number of anal rays in $E$, zoniferum helped show its position as a specialized offshoot of E. gracile but proved of little value otherwise. The number of anal spines proved significant in the E. collis group although Hubbs and Cannon stated that it was consistently two. All $E$. collis and one third of the related $E$. saludae, had only one anal spine. The vast majority of specimens of the other species of Hololepis had two anal spines although a few unusual specimens had one or three. There were modal differences between species in the numbers of pectoral rays but the character holds no promise of value in future work. Pelvic elements were I, 5 in all species of Hololepis, with only a few specimens having I, 4 or I, 6. For ease of physical 
handling, the pectoral and pelvic fins were counted on the right side. Segmented caudal rays were also counted but proved of no systematic value.

Branchiostegal Rays: These were counted on the right side. Virtually all the specimens examined had six branchiostegals, with a few deviations to five or seven.

Cephalic Pores: As pointed out by Hubbs and Cannon (1935), the arrangement and number of pores in the various canals on the head of the species of Hololepis are of great systematic importance. The preoperculomandibular pores (operculomandibular pores of Hubbs and Cannon) show strong modes at ten pores for the $E$. gracile group and at nine for the other species of Hololepis. E. serriferum and E. saludae usually have both interorbital pores present while most specimens of the other species of Hololepis usually lack these pores. There was no appreciable intra-specific variation in these two canals. The coronal pore is usually present in Hololepis but several populations of Etheostoma fusiforme fusiforme from the North Carolina Bay Lakes either lack the pore entirely or have it poorly developed. Studies of the relative development of the coronal pore may be of systematic value as mentioned under variation in E. f. fusiforme. Development also complicated the use of the supratemporal canal as a systematic character. Most E. fusiforme, serriferum, and gracile had this canal complete with the left and right branches uniting in a median pore at the occiput. Individuals of the E. collis group were about equally divided between complete and incomplete supratemporal canals, a feature which I consider specialized. The general picture of the growth of this canal is discussed under development in section IV. The infraorbital pores showed a number of different patterns which were modally species specific. E. serriferum (six pores) and E. gracile (eight pores) have complete infraorbital canals. The other species of Hololepis have incomplete canals with the anterior portion of the canal sepaated from the posterior portion. The northern subspecies of E. fusiforme has $2+3$ (posterior plus anterior portion) pores while the southern subspecies has $1+3$ pores with many interesting variations which are discussed fully under geographic variation in E. fusiforme. For ease of handling, pore counts of the infraorbital and preoperculomandibular canals were made on the right side of the specimens.

Condition of the Preopercle: The right side of the preopercle was examined for serrae. The condition was recorded as $\mathrm{S}$ (serrate), PS (partially serrate, or E (entire or non-serrate). Hubbs and Cannon (1935) stated that E. serriferum could be distinguished from the other species of Hololepis by the presence of serrations on its preopercle. The presence of a few preopercular serrations in some specimens of Etheostoma fusiforme barratti led some workers to believe that these specimens might represent hybrids between $E$. serriferum and E. f. barratti. Bailey (1950) used the presence of many preopercular serrations in specimens of barratti from the French Broad River as a diagnostic character of his Hololepis barratti appalachia. As discussed under geographic variation in E. fusiforme, the presence of these serrations varies in a roughly clinal manner, the percentage of individuals with them increasing from north to south.

Squamation: The parietal, interorbital, breast, opercle, preopercle, and nape were examined for the development of squamation. The number of scales was counted in the interorbital region while the area covered and the type of scales were recorded in the other areas. The interorbital region is defined as the area between the orbits anterior to the nares and posterior to a line between the eyes at the level of the coronal pore, where the parietal area begins. In $E$, serriferum and E. fusiforme, the skin with contained scales was dissected off and the scales were removed and counted under magnification. The scales were frequently small, imbedded, and sometimes in a number of vertical layers, making counting difficult. This scale count allowed the separation of races in E. serriferum and subspecies in $E$. fusiforme. As with the other squamation examinations, only adult specimens were used since these regions are less scaled or naked in juveniles.

The area covered by scales in the other regions was estimated to the nearest $10 \%$ ( similar to the method used by Lagler and Bailey, 1947). The amount of imbedding was recorded: $\mathrm{X}$ (posterior edges of the scales completely exposed), PX (scales with 
their posterior margins partly exposed), or I (scales completely imbedded in the epidermis). The type of ctenoid or cycloid scales was recorded: $T$ (ctenoid scales with at least one spine on the posterior margin), or C (cycloid scales, completely lacking ctenii). When two conditions were present in a given region, both symbols were recorded, separated by a diagonal. Thus the formula for a region might be: $50 \% \mathrm{I} / \mathrm{PX}$ $\mathrm{C} / \mathrm{T}$ meaning half the region was covered by scales of which some were imbedded and others partly exposed and some were cycloid and others ctenoid. These symbols are used in the squamation tables to save space.

The parietal region is the area from the interorbital region posterior to the supratemporal canal bounded laterally by the light line that runs just above the lateral canal. This definition excludes the single row of scales usually present beween the lateral canal and the light line. The nape region is a roughly triangular area with its base at the supratemporal canal and its apex at the origin of the first dorsal fin. The breast region is the triangular area starting on a line just anterior to the origin of the pelvic fins and extending forward to immediately behind the union of the gill covers. The opercular and preopercular regions include the surfaces of those bones and were examined on the right side.

Breeding Tubercles: Specimens were examined for breeding tubercles while counts were being made. The specimens showing maximum development of tubercles were selected for study. Breeding males of all species of the subgenus Hololepis have tubercles on the rays of the anal and pelvic fins, although the number and exact distribution of the tubercles varies between and within species. In the descriptions of breeding tubercles of each species, the rays of the anal and pelvic fins are numbered, starting behind the spines. Tubercle distributions of several species are pictured (Fig. 1).

The use of breeding tubercles as a systematic character in darters has been totally neglected. There are literature reports of breeding tubercles in nine species of darters while I have found them in more than 40 species in a study that has not been completed. As in the Cyprinidae and Catostomidae, tubercle patterns characterize some taxonomic groups. Two instances of tubercle pattern pertinent to this study are: (1) the subgenus Villora differs from the subgenus Hololepis in lacking breeding tubercles; and (2) the close relationship of E. gracile and E. zoniferum is demonstrated by their being the only species of Hololepis to have accessory breeding tubercles on their lower jaws.

Genital Papillae: As pointed out by Hubbs and Cannon (1935), breeding female $E$. serriferum possess flattened and bilobed genital papillae as contrary to the conical pointed genital papillae present in the other species of the subgenus Hololepis. As noted under the subgeneric diagnosis, Hololepis can be distinguished from Villora by its elongate genital papilla. Drawings of the different types of genital papillae are presented (Fig. 1) to supplement text descriptions.

Sex: Dissections were made on a relatively few specimens to verify external sex determinations. Thereafter sex was determined externally by the enlargement of the female genital papilla and by the more pigmented venter and dorsal, anal, and pelvic fins of the males. These characters allowed the determination of sex in specimens as small as $20 \mathrm{~mm}$. Smaller specimens were listed as juveniles.

Measurements: Due to the great abundance of other characters, and to the statement by Hubbs and Cannon (1935) about the slight value of morphometrics in Hololepis, only the standard length was taken. Standard length is particularly important in Hololepis because variation in several characters is correlated with specimen size (Section IV, development).

Range: Figures 3, 5, and 8 show the distribution of each form (based upon specimens personally examined) in relation to the Fall Line which is important in limiting the distribution of all the species of the subgenus Hololepis, except E. gracile. When several collections were available from a small area, all were not plotted. Collections of all specimens examined are given by museum number, county, and state for the various drainages. More complete locality data are given for rare forms, range extensions, or other reasons. Complete data for most collections examined may be found in my thesis (Collette, 1960).

Ecology and Habits: To become more familiar with Hololepis I have made several 
hundred collections in 21 of the 27 states where they are found. I have maintained E. serriferum, gracile, fusiforme fusiforme, and $f$. barratti in aquaria for varying lengths of time to obtain some understanding of their feeding, courtship, and other behavior.

Synonymies: I have attempted to examine all references that mention any of the Hololepis in any manner. The synonymies under each form include all references since the publication of Hubbs and Cannon's (1935) revision and all significant ones prior to that time.

Sampling: I made complete counts on a.

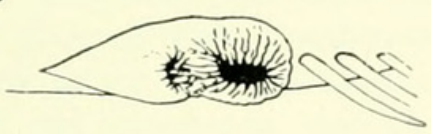

b.

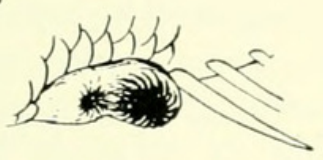

C.

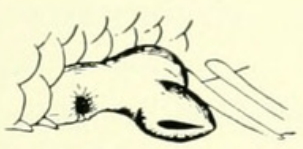

d.

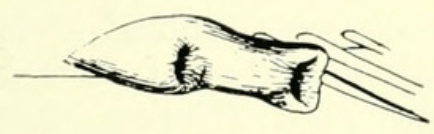

e.

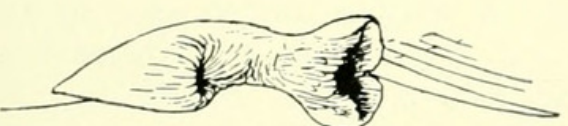

f.

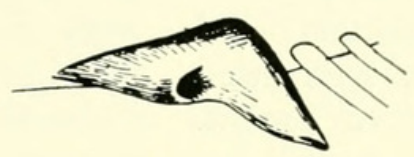

g.

h.
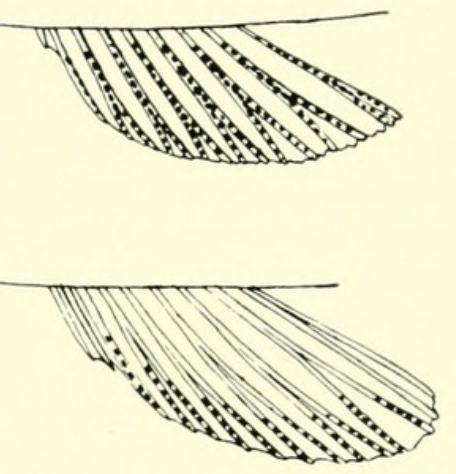

i.

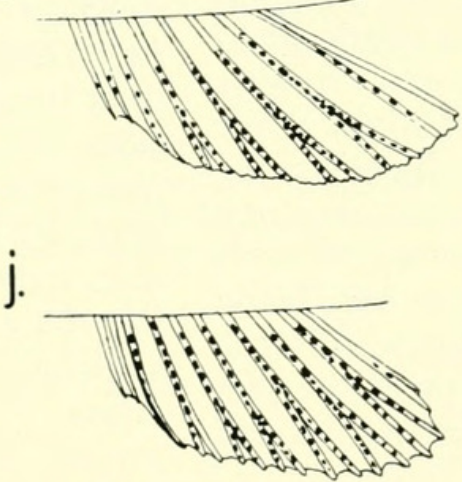

k.

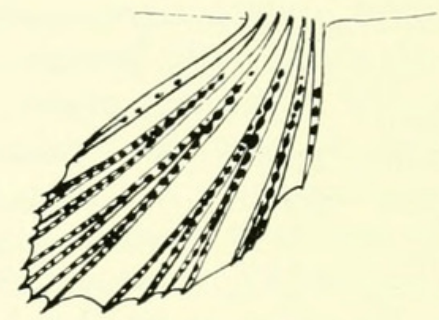

I.

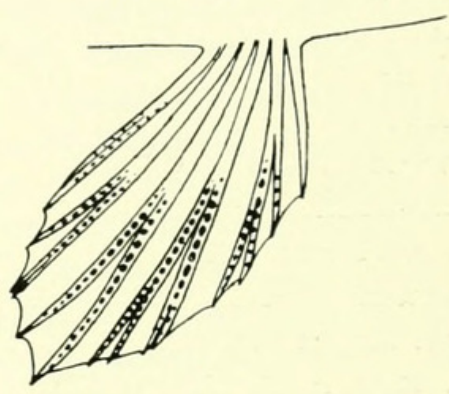

$\mathrm{m}$.

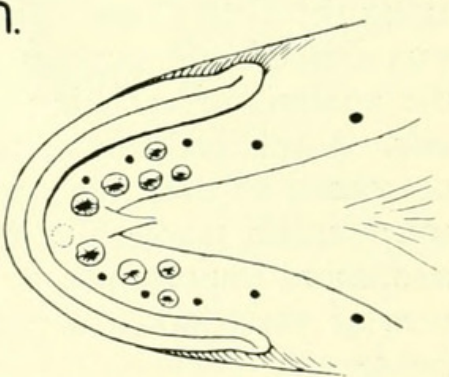

Figure. 1. Genital papillae and breeding tubercles in some of the species of the subgenera Hololepis and Villora. a. Etheostoma edwini. Genital papilla of $38.1 \mathrm{~mm}$ female taken on March 26. (CU 29754, Ga., Apalachicola dr.) b. Etheostoma edwini. Genital papilla of $38.5 \mathrm{~mm}$ female taken on March 26. (CU 29754, Ga., Apalachicola dr.) c. Etheostoma gracile. Genital papilla of $40.4 \mathrm{~mm}$ female taken on March 7. (TNHC 2750, Tex. San Jacinto dr.) d. Etheostoma serriferum. Genital papilla of $42.3 \mathrm{~mm}$ female taken on March 24. (CU 29976, Va., Chowan dr.) e. Etheostoma serriferum. Genital papilla of $56.6 \mathrm{~mm}$ female taken on March 31. (CU 15614, N. C., Cape Fear dr. f. Etheostoma f. fusiforme. Genital papilla of $37.0 \mathrm{~mm}$ female taken on April 19. (CU 31847, N. Y., L. Yaphank). g. Etheostoma c. collis. Breeding tubercles on the anal fin of $34.4 \mathrm{~mm}$ male taken on March 22. (CU 11988, N. C., Yadkin-Pee Dee dr.) h. Etheostoma gracile. Breeding tubercles on the anal fin of $36.4 \mathrm{~mm}$ male taken on March 8. (TNHC 2575, Tex., Neches or Trinity dr.) i. Etheostoma serriferum. Breeding tubercles on the anal fin of $36.0 \mathrm{~mm}$ male taken on March 23. (CU 30122, S. C., Pee Dee dr.) j. Etheostoma f. fusiforme. Breeding tubercles on the anal fin of $36.0 \mathrm{~mm}$ male taken on April 19 . (CU 31847, N. Y., Lake Yaphank) k. Etheostoma gracile. Breeding tubercles on the right pelvic fin of $37.2 \mathrm{~mm}$ male taken on April 15. (OAM 4192, Okla., Red dr.) 1. Etheostoma serriferum. Breeding tubercles on the right pelvic fin of $43.9 \mathrm{~mm}$ male taken on March 23. (CU 30122, S. C., Pee Dee dr.) m. Etheostoma gracile. Breeding tubercles on the chin of $37.2 \mathrm{~mm}$ male taken on April 15. (OAM 4192, Okla., Red dr.)

(Drawings by Rudolph J. Miller) 
virtually all the specimens at the beginning of this study. In a few cases, where a large series was available from a single locality, some specimens were omitted. As the study progressed and certain characters were shown to be either constant or to vary within a narrow range with no significant geographical variation, counts were made only on part of the available specimens. Thus, fewer counts were made on pectoral and pelvic fin rays, branchiostegals, segmented caudal rays, and coronal pore development. The number of specimens examined for squamation is less than for meristic counts because only adult specimens could be used (Section IV, development).

Presentation of Results: Only characters that are virtually constant for the subgenus are given in the subgeneric diagnosis. Counts that show significant interspecific, but relatively little intraspecific variation are presented in the species comparisons tables (Tables 38-49). The two species of the subgenus Villora are also included in these tables for comparison. Characters showing geographic variation are presented in tables by species or species groups. In these tables populations are listed down the page in geographic order from north to south along the Atlantic Coast and from east to west along the Gulf Coast. The Mississippi River was divided into sections and subsections for the analysis of variation in Etheostoma gracile. A relatively large number of tables is presented so that the reader may see clearly why certain taxonomic decisions were made and, more importantly, so that the entire picture of variation in a particular species can be seen.

\section{Causes of VARIATION}

In any variational study, it is necessary to examine the types of variation present and to consider the factors that may be involved in causing them. While all types of variation are interesting from an evolutionary point of view, it is desirable to eliminate non-genetic sources of variation for taxonomic purposes. The following sections consider variation due to asymmetry, sexual dimorphism, year classes and development.

Left and Right Sides: As has frequently been done by ichthyologists, Hubbs and Cannon (1935) in their revision of Hololepis sometimes made counts on the left side, sometimes on the right side, and sometimes on both sides. Nowhere do they mention why they feel this is justified or even the fact that they are doing it. However, by comparing the number of specimens they examined with the number of counts of median and bilateral structures, I found that for median counts, they gave counts for up to the number of specimens examined while for bilateral counts, they gave up to twice as many counts as specimens examined. I do not feel that this is proper for two reasons. Firstly, as stated clearly by Hubbs and Hubbs (1945, page 300): "Since many superficial as well as internal characters are often more or less different on the two sides, it is obviously a wise policy in systematic studies to count or measure given characters consistently on one side, or to study both sides." Secondly, even if there are no differences between sides, use of both sides can lead to misinterpretations unless the two sides are independent, which seems quite unlikely.

In order to interpret some of Hubbs and Cannon's conclusions, the possibility of leftright correlation was examined using collections of Etheostoma f. fusiforme made in two Long Island, N. Y. ponds. Pored and total lateral-line scales were counted on both sides of these fish and the left side was plotted against the right (Collette, 1960: Figs. 1-2). With regard to the pored lateralline scales, the percent of individuals having the same count on each side was $23 \%$, a difference of plus or minus one or two scales 30 and $34 \%$, and a difference of greater than two scales 8 and $4 \%$. For the total lateral-line scales, the percentages were $19 \%$ no difference, 24 and $25 \%$ with a difference of plus or minus one or two scales, and 11 and $11 \%$ with a difference greater than two scales between sides. This means that if both sides were counted and put into a single frequency distribution, the sample size would appear to be doubled with the probability that the range would not be increased nearly as much as if the sample size had really been doubled. In the case of three of Hubbs and Cannon's subspecies of $E$. fusiforme ( $f$. insulae from Nantucket Island, f. metaegadi from Cape Cod, and $f$. atraquae from the Potomac River), each of which is based upon a single sample, the supposed subspecies appears more homo- 
geneous and therefore more different from other populations of the species than is really the case. (The validity of these forms are discussed at length under geographic variation in E. fusiforme.)

Sexual Dimorphism and Year Class Variation: The variation due to sexual dimorphism and year class differences is frequently not considered in taxonomic studies. Inspection of the data showed that such variation could be significant only in the number of lateral-line scales. Table 1 shows comparisons between males and females in the number of pored and total lateral-line scales. Samples for single localities were used for all but one species. A sufficiently large sample of $E$. saludae was not available, so it was necessary to lump all the samples. This should not introduce error due to geographic variation because this species has a restricted range. No significant differences are apparent between the sexes in these characters (Table 1 ).

Little material of different year classes from single localities is available. Three year classes of E. collis collis from the Yadkin River and year classes of E. fusiforme fusiforme from two of the North Carolina Bay Lakes and a Long Island pond were employed in comparisons. The relative contributions of sexual dimorphism and year class variation were analyzed by the use of an $\mathrm{R}$ X 2 table with disproportionate subclass numbers (Snedecor, 1956). The preliminary analyses of variance show that there is no significant variation due to sexual dimorphism or year class variation for E. c. collis $(\mathrm{F}=1.782$ for pored lateral-line scales and 1.636 for total) or for E. f. fusiforme from Lake Yaphank ( $\mathrm{F}=0.938$ and 1.027$)$ and Jones Lake ( $\mathrm{F}=0.931$ and 1.834). There are also no significant differences in pored lateral-line scales between different year classes in White Lake $(\mathrm{F}=2.219)$. There is a significant difference at the $99 \%$ level $(\mathrm{F}=4.116)$ in total lateral-line scales (Table 2). To determine whether this was due to sexual dimorphism or year class variation the analysis was completed. Table 2 presents the means for year classes and sexes, the preliminary analysis, and the completed analysis. The difference between sexes is significant at the $95 \%$ level. This is not deemed important taxonomically because the total number of lateral-line scales in E. fusiforme is not a significant character in analyzing geographic variation.

Development: The development of squa-

TABLE 1.

Variation between sexes in pored and total lateral-line scales in Etheostoma (Hololepis) species

\begin{tabular}{|c|c|c|c|c|c|c|c|c|}
\hline $\begin{array}{l}\text { Species } \\
\text { Locality }\end{array}$ & & \multicolumn{2}{|c|}{$\begin{array}{l}\text { serriferum } \\
\text { Pee Dee }\end{array}$} & \multicolumn{3}{|c|}{$\begin{array}{l}\text { gracile } \\
\text { Red }\end{array}$} & \multicolumn{2}{|c|}{$\begin{array}{l}\text { f. barratti } \\
\text { Savannah }\end{array}$} \\
\hline \multicolumn{9}{|c|}{ Pored Lateral-line Scales } \\
\hline Sex & \multicolumn{2}{|r|}{ M } & $\mathrm{F}$ & M & \multicolumn{2}{|l|}{$\mathrm{F}$} & M & $\mathrm{F}$ \\
\hline & \multicolumn{2}{|r|}{23} & 22 & 21 & \multicolumn{2}{|c|}{26} & 33 & 44 \\
\hline Range & \multicolumn{2}{|r|}{$29-38$} & $28-39$ & $17-25$ & \multicolumn{2}{|c|}{$15-23$} & $20-37$ & $18-34$ \\
\hline$\overline{\mathrm{x}}$ & \multicolumn{2}{|r|}{32.8} & 34.9 & 20.0 & \multicolumn{2}{|c|}{18.3} & 26.3 & 25.0 \\
\hline \multicolumn{9}{|c|}{ Total Lateral-line Scales } \\
\hline & \multirow{3}{*}{\multicolumn{2}{|c|}{$\begin{array}{l}24 \\
50-60 \\
54.1\end{array}$}} & 23 & 21 & \multirow{3}{*}{\multicolumn{2}{|c|}{$\begin{array}{l}26 \\
42-50 \\
46.9\end{array}$}} & 33 & 47 \\
\hline Range & & & 48-62 & $45-53$ & & & $51-62$ & $50-63$ \\
\hline$\overline{\mathrm{x}}$ & & & 54.4 & 48.1 & & & 56.2 & 54.8 \\
\hline Species & \multirow{2}{*}{\multicolumn{4}{|c|}{$\begin{array}{l}\text { fusiforme fusiforme } \\
\text { Chowan Chesapeak }\end{array}$}} & \multirow{2}{*}{\multicolumn{2}{|c|}{$\begin{array}{l}\text { saludae } \\
\text { All specimens }\end{array}$}} & \multirow{2}{*}{\multicolumn{2}{|c|}{$\begin{array}{l}\text { c. collis } \\
\text { Yadkin }\end{array}$}} \\
\hline Locality & & Chowan & Chesapea & & & & & \\
\hline \multicolumn{9}{|c|}{ Pored Lateral-line Scales } \\
\hline Sex & M & $\mathrm{F}$ & M & $\mathrm{F}$ & M & $\mathrm{F}$ & M & $\mathrm{F}$ \\
\hline $\mathrm{N}$ & 31 & 54 & 39 & 21 & 26 & 56 & 17 & 14 \\
\hline Range & $11-17$ & $11-19$ & $13-23$ & $14-24$ & $11-23$ & $5-29$ & $9-23$ & $11-24$ \\
\hline$\overline{\mathrm{x}}$ & 14.2 & 14.6 & 17.9 & 18.0 & 17.2 & 16.7 & 15.5 & 15.5 \\
\hline \multicolumn{9}{|c|}{ Total Lateral-line Scales } \\
\hline & 31 & 56 & 39 & 23 & 29 & 54 & 17 & 13 \\
\hline Range & $41-54$ & $42-54$ & $46-58$ & $48-58$ & $36-47$ & $37-50$ & $42-49$ & $40-47$ \\
\hline$\overline{\mathrm{x}}$ & 48.3 & 48.4 & 51.6 & 51.2 & 41.2 & 42.1 & 44.8 & 44.1 \\
\hline
\end{tabular}


TABLE 2.

Variation of total lateral-line scales between year classes and sexes in Etheostoma f. fusiforme from White Lake, N.C.

\begin{tabular}{|c|c|c|c|c|c|c|c|}
\hline$\frac{\text { Year }}{1947}$ & \multicolumn{2}{|c|}{$\mathrm{n}_{1}$ Male } & \multicolumn{2}{|c|}{$\mathrm{n}_{2}{ }_{\text {Female }}^{\mathrm{F}_{2}}$} & $\begin{array}{c}\text { W } \\
17.7183\end{array}$ & $\begin{array}{c}\mathrm{D} \\
0.55\end{array}$ & $\begin{array}{c}\text { WD } \\
9.7451\end{array}$ \\
\hline $\begin{array}{l}1947 \\
1958 \\
1959\end{array}$ & $\begin{array}{l}37 \\
11 \\
13\end{array}$ & $\begin{array}{l}49.51 \\
48.64 \\
48.54\end{array}$ & $\begin{array}{l}34 \\
37 \\
31\end{array}$ & $\begin{array}{l}50.06 \\
49.38 \\
51.32\end{array}$ & $\begin{array}{r}17.7183 \\
8.4792 \\
9.1591\end{array}$ & $\begin{array}{l}0.55 \\
0.74 \\
2.78\end{array}$ & $\begin{array}{r}9.7451 \\
6.2746 \\
25.4623\end{array}$ \\
\hline & 61 & & 102 & & & & 41.4820 \\
\hline
\end{tabular}

Preliminary Analysis of Variance of Original Data

\begin{tabular}{lrccc}
\hline Source of Variation & d.f. & Sum of Squares & Mean Square & F \\
\hline Treatments & 5 & 119.341 & 23.868 & $4.116^{* *}$ \\
$\quad$ Years & 2 & 38.408 & 19.204 & \\
Sexes & 1 & 41.975 & 41.975 & \\
Error & 157 & 872.377 & 5.556 & \\
Total & 162 & 991.718 & & \\
\hline \multicolumn{5}{c}{ Completed Analysis } \\
\hline Sexes & 1 & 48.669 & 24.334 & $1.380^{*}$ \\
Years & 2 & 18.039 & 9.020 & 2.890 N.S. \\
Interaction & 2 & 32.112 & 16.056 & \\
Error & 157 & 872.377 & 5.556 & \\
Total & 162 & 991.718 & & \\
\hline
\end{tabular}

(Analysis of variance with an $R \times 2$ table and disproportionate subclass numbers, ${ }^{*}$ is significant at the $95 \%$ level, ** at the $99 \%$ level)

mation, pored lateral-line scales, supratemporal canal, infraorbital canal, and coronal pore proved to be important in studying variation in Hololepis. This was especially true in understanding the extreme variation in number of pored lateral-line scales in Etheostoma fusiforme fusiforme from the North Carolina Bay Lakes and in E. f. barratti from Crystal Lake, Georgia. While specific information on development will be found under each species, I think it will be of value to briefly state the over-all pattern of development as I understand it.

Scales first appear on the caudal peduncle at the base of the caudal fin when the fish are about $15 \mathrm{~mm}$ SL. They then extend forward along the lateral line and spread dorsally and ventrally from the lateral line. The breast, belly, nape and head are the last regions to develop scales. Areas that have ctenoid scales in the adult develop scales faster than areas that have imbedded cycloid scales in the adult. The pattern of scale development is thus very similar to that given for Micropterus dolomieui (Everhart, 1949), Pomoxis nigromaculatus (Ward and Leonard, 1954), Perca flavescens (Pycha and Smith, 1955), etc.

Pored lateral-line scales do not develop until after the body squamation is virtually complete. Two lateral ridges form on each of the most anterior scales in the lateral line. These ridges grow higher and then meet over the middle of the scale to form the pore. The number of pored scales increases rapidly through $5-10 \mathrm{~mm}$ until the definitive number is reached by about $25 \mathrm{~mm} \mathrm{SL}$ (Figs. 11, 12). Populations of some species (e.g., E. fusiforme) are neotenic in retaining a reduced number of pored scales.

The supratemporal canal is incomplete in juveniles of all species of Hololepis, and becomes complete in adults of most species by the two branches growing together leaving a median pore as a vestige of their former separation. An incomplete supratemporal canal may be characteristic of populations of a species, an entire species, or larger categories. The infraorbital canal grows posteriorly from its origin behind the nostril and anteriorly from its junction with the lateral canal. In some species the canal is interrupted while in others the two portions grow together to form a complete canal. The coronal pore grows posteriorly from the connection between the supraorbital canals. Specimens sufficiently small were not available for a study of the development of the other canals.

It is apparent that one of the features of 
evolution in the darters is the relative completeness of development of some of the characters mentioned above. Independently in many different lines of darters, various primitive characters have been repressed. Thus in the subgenus Nothonotus, E. tippecanoe stands out as the most advanced species being the smallest in size, having the belly squamation reduced, and having an incomplete lateral line. Microperca, the most advanced subgenus of Etheostoma, shows the effects of incomplete development in almost all characters: dorsal spines, anal rays, lateral-line scales, pored lateral-line scales, size, etc. The three species of Microperca can be ranked phylogenetically by the amount of development of various characters: the most primitive (E. proeliare) has 2-7 pored scales and the preopercle and opercle are scaly. The two more advanced species lack pored scales and scales in those areas. E. fonticola, the most advanced species, has the anal spines reduced to one. The same type of situation is shown in Hololepis in section VI, evolutionary relationships.

\section{Subgeneric Diagnosis} Hololepis Agassiz, 1863

Hololepis Agassiz, in Putnam, 1863: 4 (type species Boleosoma barratti Holbrook, 1855 , by subsequent designation of Jordan and Gilbert, 1877: 93 ).

Copelandellus Jordan and Evermann,1896: 1100 (type species Poecilichthys quiescens Jordan, 1884, by original designation) .

Lateral line arched upward anteriorly and always incomplete; pored lateral-line scales 0 to 45 ; unpored 12 to 52 ; total 35 to 66; infraorbital canal complete or incomplete; interorbital pores 0,1 , or 2 ; supratemporal canal usually complete in adults; coronal pore usually present; preoperculomandibular pores 6 to 12 , usually 9 or 10 ; vomer and palatine toothed; preopercle entire, partially serrate, or serrate, entire in most species; branchiostegal membranes narrowly conjoined; branchiostegal rays usually 6 ; opercle, preopercle, breast, nape, interorbital, and parietal regions naked to fully covered with imbedded cycloid to exposed ctenoid scales; belly covered at least in part with unspecialized cycloid or ctenoid scales; flesh opaque; body rather compressed and elongate to somewhat stocky; vertebrae 35 to
41; premaxillary frenum broad; first dorsal fin moderately high, with 7 to 13 spines which lack thickened, fleshy tips; anal spines 2 in most species, the first somewhat shorter and thicker than the second, the second equal to one-half to three-quarters of the length of the first anal ray; pelvic fins closely approximated, separated by one-half to three-quarters of the fin base; pectoral rays 10 to 15 ; second dorsal rays 8 to 17 ; anal rays 4 to 10 ; genital papilla of breeding female modified into an elongate and either cylindrical or somewhat flattened and bilobed tube; breeding tubercles present in breeding males on the anal fin rays and the undersides of the pelvic fin rays; maximum size of males equal to or less than that of females; habitat slow-moving waters such as lakes, swamps, and the backwaters of streams.

The subgenus Hololepis appears to be most closely related to the subgenus Microperca, and to some species of Oligocephalus (e.g., Etheostoma exile). The subgenus Hololepis is distinguished from Microperca by a more complete lateral line; more lateralline scales; the presence of a premaxillary frenum; and the absence of the peculiar flap on the pelvic fins of breeding male Microperca. Etheostoma (Hololepis) collis and saludae are the species of Hololepis that resemble most the species of Microperca in body shape, coloration, male breeding pigmentation, reduced number of pored lateralline scales, and having forms with both one and two anal spines. Microperca, while distinguishable as a subgenus, appears to be further along on the same phyletic line as Hololepis.

From the subgenus Villora, Hololepis is distinguished by a more highly arched and less complete lateral line; an elongate genital papilla in breeding females as contrasted with the low tube crowned with villi in Villora; presence of nuptial tubercles on the pelvic and anal fins of breeding males; lack of a strongly developed black humeral spot; maximum size of males less than that of females; and a habitat of slow, muddy waters ( see also diagnosis of Villora in Collette and Yerger, 1962).

Etheostoma (Oligocephalus) exile shows a number of similarities to the species of the subgenus Hololepis. These include compressed body form; arching of the lateral line, incomplete development of the lateral 
line, and slow water habitat. On the other hand, male $E$. exile have much more brilliant breeding colors than do any of the species of the subgenus Hololepis and apparently lack breeding tubercles.

I think that the phyletic line that goes from Hololepis through E. collis and E. saludae, culminating in Microperca, probably has its origin somewhere in Oligocephalus, perhaps near E. exile.

\section{Evolutionary Relationships in HOLOLEPIS}

The characters used to delimit subspecies, species, species groups, subgenera, and genera in the darters show many cases of convergent and divergent evolution as noted by Bailey (in Bailey, Winn and Smith, 1954, p. 141). Characters which can be considered as generalized in the darters include: serrate preopercle; conical genital papilla; deep compressed body; relatively large body size; gill membranes separate; most areas of the body covered with ctenoid scales; lateral line complete and not arched; ten preoperculomandibular pores; infraorbital canal complete with eight pores; supratemporal canal complete; interorbital pores present; two anal spines; 41-45 vertebrae; sexual dimorphism and sex recognition weakly developed; females equal to or larger in size than males; non-territorial; eggs scattered over wide area; no parental care; habitat of large streams (modified from Hubbs and Cannon, 1935; Bailey and Gosline, 1955; Winn, 1958; etc.).

Of the species in the subgenus Hololepis, E. serriferum is the most primitive in virtually all characters. It is the largest species of the subgenus, has a serrate preopercle, interorbital pores present, infraorbital canal complete (although pores reduced to six); and has a more complete lateral line, more dorsal spines and rays, more scales below the lateral line, more lateral-line scales, and a scalier nape, parietal, and interorbital than the other Hololepis. Its only real specialization is the bilobed genital papilla of the breeding female although it also shows a reduction in the number of preoperculomandibular pores (to nine) and infraorbital pores.

Etheostoma gracile and E. zoniferum share a number of characters which indicate that they are closely related. These include ten preoperculomandibular pores; in- terorbital pores absent; naked breast, parietal, and interorbital; green vertical bars on the sides in life; rows of red spots in the dorsal fins of breeding males; the presence of accessory breeding tubercles on the chins of breeding males; and territorial behavior. There is a combination of primitive characters (ten POM pores) with specialized ones (INT absent, breast and nape naked, territorial behavior). Most of the characters that differentiate E. zoniferum from E. gracile indicate that it is an offshoot of $E$. gracile. This is especially true of the most important differentiating character which is the incomplete infraorbital canal in zoniferum. E. zoniferum also shows a reduction in the number of anal rays, scales above and below the lateral line, pored lateral-line scales, squamation of the breast and preopercle, and usually has the supratemporal canal incomplete. Only in the more extensive opercular squamation does zoniferum appear less specialized than gracile. Apparently, zoniferum differentiated from gracile after isolation in the Alabama and Tombigbee Rivers, east of the range of the widespread gracile.

Etheostoma fusiforme is the most widespread species of Hololepis. It shows a few more advanced characters over the $E$. gracile group such as having the preoperculomandibular pores reduced to nine, and the infraorbital canal interrupted with $1+3$ or $2+$ 3 pores. In several other characters it is slightly more primitive than the $E$. gracile group. It has slightly more lateral-line scales and vertebrae; scalier interorbital, parietal and breast; the occurrence of individuals with partially serrate preopercles; and territoriality is absent. In all respects but one, E. fusiforme fusiforme is clearly a specialized offshoot of E. f. barratti. It has fewer pored lateral-line scales, a lower percentage of individuals with partially serrate preopercles, and a reduced squamation, especially in the interorbital and parietal regions. E. $f$. barratti, however, has a higher percentage of individuals with $1+3$ infraorbital pores while $f$. fusiforme usually has $2+3$. Some of these characters show clinal variations. The extent of squamation and the percentage of individuals with partially serrate preopercles increases toward the south. Other characters have a much more complex vari- 
ation as discussed at length under geographic variation in E. fusiforme.

The Etheostoma collis group is the most specialized in the subgenus. Here the pored lateral-line scales are further reduced in number; the supratemporal canal is frequently incomplete; there are fewer vertebrae, fewer lateral-line scales; and one anal spine is frequently absent. The three forms of this group have deserted the lowland habitat characteristic of the other Hololepis for backwaters of Atlantic Piedmont streams. E. saludae is clearly the most primitive of the three since it retains the interorbital pores and only about a third of the specimens have the anal spines reduced to one. E. saludae and E. collis lepidinion are scalier than E. c. collis, especially in the nape and breast regions. Etheostoma c. collis is the most specialized Hololepis. It has one anal spine; no interorbital pores; infraorbital $1+3$; breast, nape, parietal, and interorbital naked. There is still some doubt in my mind as to the taxonomic categories to use for the E. collis group. There may be one species with three subspecies, three species, or two species with the Roanoke-Neuse River form a subspecies of E. collis. In two respects, E. saludae is intermediate between E. c. collis and E. c. lepidinion: number of infraorbital pores and squamation of the nape. On the basis of one anal spine and the absence of interorbital pores, I have decided to consider the Roanoke-Neuse and Pee Dee-Catawba forms as conspecific, thus making lepidinion a subspecies of $E$. collis.

Thus it is apparent that the species of Hololepis form four species groups, and within each of these groups there are specialized and generalized characters so that these four lines are offshoots of some more primitive stock. The intra-group relationships are clearer: E, serriferum is the most primitive Hololepis; E. zoniferum is a specialized derivative of E. gracile; E. fusiforme fusiforme has undergone a reduction in squamation and other characters in developing from E. f. barratti; E. saludae has given rise to $E$. collis lepidinion which has subsequently differentiated into $E$. collis collis, probably the most advanced of the Hololepis.

\section{Species AcCounts \\ Etheostoma serriferum (Hubbs and Cannon)}

Boleichthys fusiformis-Driver, 1942:285 (range in key partly serriferum).

Hololepis serrifer-Hubbs and Cannon, 1935:31-36, pl. I, (original description); Fowler, 1945:40, 139 (N.C.), 196 (S.C.); Freeman, 1952a:37 (Congaree and Wateree r., Richland Co., S.C.); Bailey and Frey, 1951:191, 203 (Ellis L., N.C.); Anderson and Freeman, 1957: 106 (Congaree R., S.C.); Randall, 1958:342 (Catawba-Wateree R., S.C.).

Etheostoma serriferum-Bailey and Gosline, 1955:20, 44 (number of vertebrae); Eddy, 1957:219-220; Moore, 1957:197; Collette, 1961:2051.

Misidentifications-Etheostoma fusiforme barratti as Hololepis serrifer, Fowler, 1945: 252 (Savannah R., Ga.).

Types-Holotype, UMMZ 107053; 52 mm male; N.C., Wake Co., Buffalo Cr.;

\section{Key to the Species and Subspecies of the Subgenus HoLOLEPIS}

1. Infraorbital canal complete

Infraorbital canal interrupted

2. Preopercle strongly serrate; infraorbital pores 6

Preopercle entire; infraorbital pores 8

E. serriferum

. Preopercle entire; infraorbital pores 8 mital pores absent

Preoperculomandibular pores 10 ; interorbital pores absent; anal spines 2 E. zoniferum Preoperculomandibular pores 9 ; interorbital pores 0 , 1 , or 2 ; anal spines 1 or $2 \quad 4$

4. Interorbital pores absent; breast squamation $100 \%$; interorbital with $0-37$ scales

Interorbital pores 0,1 , or 2 ;

5. Interorbital with $0-12$ scales, usually $0-4$;infraorbital pores usually $(80 \%) 2+3$ E. fusiforme fusiforme Interorbital with $1-36$ scales, usually 5-20; infraorbital pores usually $(70 \%) 1+3$

6. Anal spines 1 or 2 ; interorbital pores present E. fusiforme barratti

7. Anal spines 1; interorbital pores usually absent squamation $10-80 \%$; nape squamation $70-100 \%$; infraorbital pores usually E. saludae $1+4$ E. collis LEPIDINION Breast naked; nape squamation $0-40 \%$; infraorbital pores usually $1+3$ E. collis collis 
Wendell; Brimley and Harris; Nov. 19, 1925. Paratypes: all other specimens examined by Hubbs and Cannon (1935:31-33).

Diagnosis-Differs from the other species of Hololepis by having a completely serrate preopercle. The female has a flattened bilobed genital papilla. There are two intense black spots at the base of the caudal with a pair of fainter spots above and below them. E. serriferum has more second dorsal rays (mode: 14, $\overline{\mathrm{x}}:$ 13.6) than other species of Hololepis (modes: 11 or 12, $\overline{\mathrm{x}}$ : 10.6-12.4) and more scales below the lateral line (mode: 12, $\overline{\mathrm{x}}: 11.8$ ) than other species of Hololepis (mode: 8 or $9, \overline{\mathrm{x}}:$ 8.1-8.9). Both interorbital pores are usually present as in E, saludae. Parietal region completely covered with scales. Infraorbital canal complete as in $E$. zoniferum but usually with only six pores instead of eight. Maximum size: males$52.1 \mathrm{~mm}$ (CU 29981, Roanoke R.) and females-57.4 (CU 35059, Santee R.).

Coloration-The first dorsal fin of the female is clear or has small melanophores concentrated on or near the spines and between their bases. The second dorsal fin is indistinctly barred and may have pigment at the base of the membranes. The anal either lacks pigment or has melanophores concentrated on the rays in groups, which give a barred appearance. Both pectoral and pelvic fins are clear or have melanophores outlining the rays. The caudal is barred; pigment is also present on the proximal portion of the membranes in some specimens. The belly and breast are usually immaculate, but sometimes have a few scattered large melanophores. The cheek has a few large melanophores. All four orbital bars are present but not especially prominent; the supraorbital extends onto the eye. The pored portion of the lateral line appears as a narrow light line. A pair of intense black spots occur above and below the midcaudal base. Faint spots are found at both the dorsal and ventral bases of the caudal in most specimens. Black lateral blotches are usually fused into a band below the lateral line. Some specimens have uniformly tan sides without lateral blotches. Dorsal saddles and blotches are absent. The genital papilla is usually immaculate but may have some pigment posteriorly. Figure 2 shows a female.

The cheek and first dorsal fin of the nonbreeding male are colored like those of the female but have a few more melanophores. The anal fin has scattered melanophores on the membranes and rays; there are fewer on the rays. The belly and breast vary from

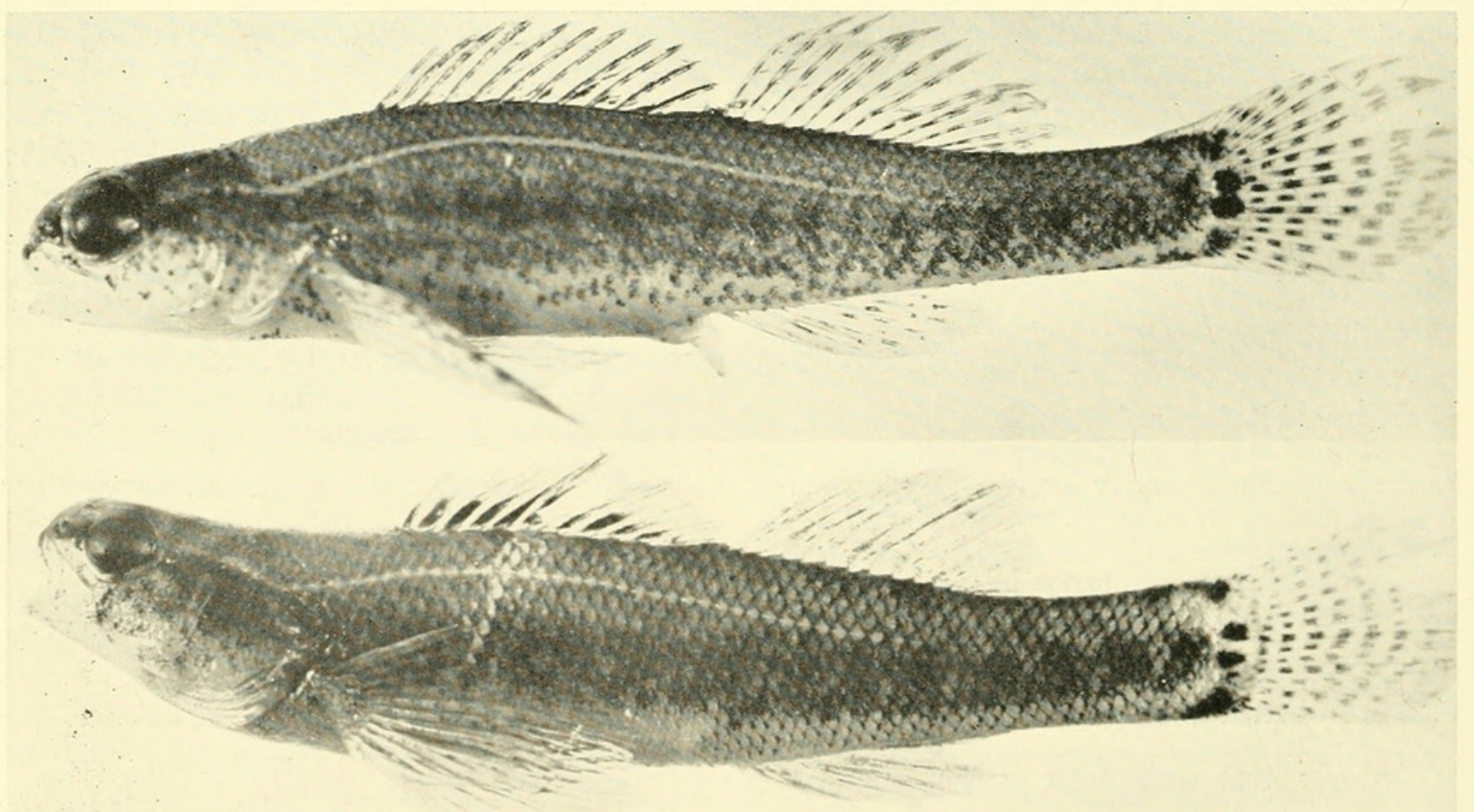

Figure 2. Breeding patterns of Etheostoma serriferum. (upper) female; CU 29989; $41.0 \mathrm{~mm}$; S.C., Chesterfield Co., Pee Dee dr.; Mar. 29. 1956. (lower) male; CU 29981; $56.0 \mathrm{~mm}$; N.C., Martin Co., Roanoke dr.; Mar. 24, 1956. (Photographs by Douglass M. Payne) 
immaculate to an overall sprinkling of small melanophores. The orbital bars are more prominent in some non-breeding males than in females. The narrow light line along the pored portion of the lateral line appears more prominent in the male because of the darker sides. Melanophores usually form a band that encircles the base of the genital papilla.

In the breeding male the pectoral and caudal fins, basi-caudal spots, sides, dorsal surface, and the genital papilla are similar to the non-breeding male; other areas are darker. The basal portion of the first dorsal fin is almost solid black. A narrow clear band borders the membranes between the last spines. The membranes of the second dorsal fin are covered with large melanaphores which do not form rectangular blotches as they do in E. saludae and collis. The anal and pelvic fins and the belly and breast are uniformly covered with small melanophores. The suborbital bars are less prominent than in the female because the cheeks are darker. The light line along the pored portion of the lateral line is interrupted by some pigment on the distal parts of the scales. The breeding pattern of a male is shown in Figure 2. Hubbs and Cannon (1935:36) used Jordan's (1890:120) description for life colors. The description mentions red on various areas of the body which does not at all agree with my observations.

Breeding Tubercles-Breeding tubercles are present on the anal rays and the lower surface of the pelvic rays. In a $40.2 \mathrm{~mm}$ male taken on March 24-25 (UG 152) from the Ogeechee River, breeding tubercles occur on the distal one third of anal rays one through four, the distal quarter of pelvic rays one through three, and the distal eighth of pelvic ray number four. In a male taken on March 30 (CU 15636, \#2) from the Pee Dee River, tubercles are present on the distal two thirds of the anal rays, mostly on the main branches, and on the distal one third of the pelvic rays, mostly on the smaller branches. At maximum development the tubercles are moderately large. Figure 11 shows their distribution on the pelvic fin of a $43.9 \mathrm{~mm}$ male taken on March 23 (CU 30122) and Figure 1i shows the tubercles on the anal fin of a $36.0 \mathrm{~mm}$ male from the same collection.
Genital Papilla-The other species of the subgenus Hololepis have a moderately elongate tube with a sharp or blunt end, but in E. serriferum the females have the tip of the tube flattened and bilobed. The long axis of the opening of the papilla is perpendicular to the papilla, while in other species of Hololepis the opening is parallel to the papilla. Figure 1d shows the papilla of a female taken on March 24 from the Chowan River (CU 29976). Figure le shows the most extreme development of a papilla noted in E. serriferum: a female $(56.6 \mathrm{~mm}$ ) from the Cape Fear River taken on March 31 (CU 15614).

Habitat-E. serriferum prefers slightly more open, better oxygenated, and less sluggish waters than most species of Hololepis. In collections containing both E. fusiforme and $E$. serriferum, the former species is limited to the backwaters of streams, while the latter is usually found in clumps of weeds in the middle of the stream. The larger, less compressed body of $E$. serriferum perhaps permits this species to resist the force of the current more efficiently than E. fusiforme. However, both species have been taken together in some lakes (e.g., Ellis Lake, N. C. ).

At 16 localities where I collected E. serriferum, the current was slow (5), slow to moderate (3), and moderate ( 8 ); the bottom composed partly of sand in 13 collections, mud and/or silt (8), detritus (4), and clay (3); the vegetation ranged from sparse emergents along the shore to dense stands of aquatic plants (in Ellis Lake); the water was usually clear and stained brown; the width of the streams varied from 5 to 30 feet (also taken in two lakes); and the shore was wooded or open.

Species Associates-Examination of my field notes for 16 North Carolina collections which contained $E$. serriferum shows the following to be frequent associates (number of collections present with serriferum given in parentheses): Apbredoderus sayanus (11); Etheostoma f. fusiforme or f. barratti (8); Esox a. americanus (8); Gambusia affinis bolbrooki (7); Chaenobryttus gulosus (7); Enneacanthus gloriosus (6); Notemigonus crysoleucas (6); and Lepomis macrocbirus (6). All the associated species can tolerate the sluggish, acid, brown-stained waters characteristic of the Atlantic Coastal Plain. 
Habits-Specimens kept in aquaria have acted much like E. fusiforme (q.v.). They rested upon the bottom most of the time and darted forward after food such as white worms, tubificid worms, or pieces of earthworms. Occasionally they swam up into the plants and rested there. As with E. fusiforme, there was never any indication of any territoriality.

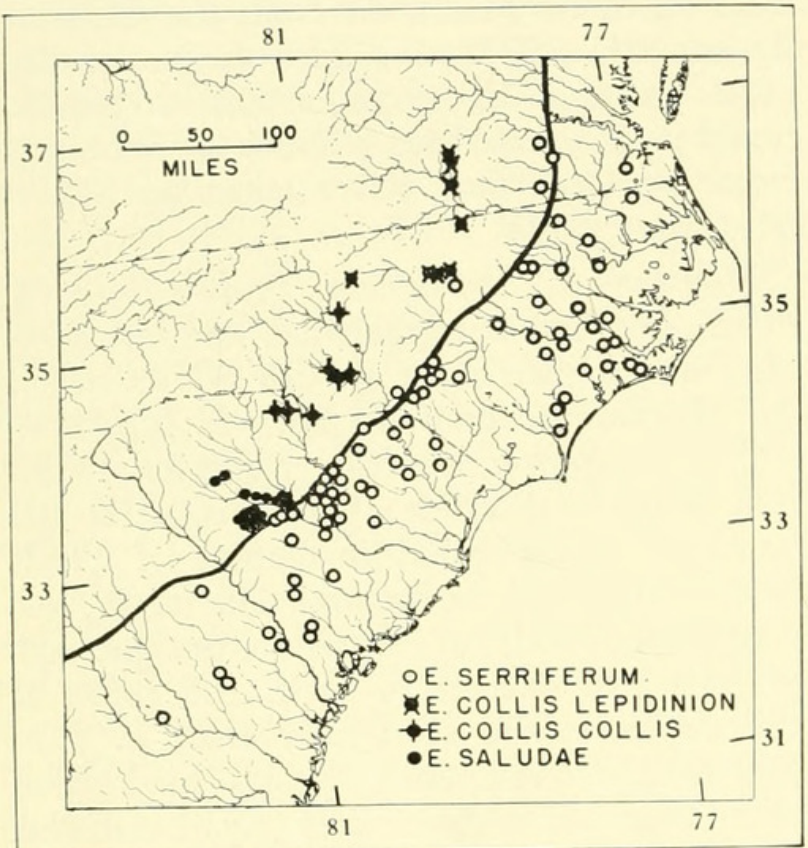

Figure 3. The distribution of Etheostoma serriferum, $E$. collis, and $E$. saludae in relation to the Fall Line. (Based upon specimens examined.

Distribution-Found along the Atlantic Coastal Plain, usually below the Fall Line, from the Dismal Swamp of southeastern Virginia to the Altamaha River of Georgia. This extends the range given by Hubbs and Cannon (1935) south by three river systems. It has been taken above the Fall Line in Mud Creek, a tributary of the Cape Fear River, at Durham, N. C. However, Mud Creek is like a typical sluggish Coastal Plain stream. Another typical Coastal Plain species, Aphredoderus sayanus, was also taken here. Figure 3 shows the distribution of $E$. serriferum collections examined.

This distribution coincides with that of Chologaster cornutus. Woods and Inger (1957:249-250) commented that there appeared to be no reason why Chologaster should not range into the Okefenokee Swamp or west into Alabama. Several species with similar habitat requirements, such as Gambusia affinis, Apbredoderus sayanus, and Elassoma do range westward on the Gulf side of the former Mississippi Embayment to beyond the Mississippi River. (They also erroneously listed Umbra pygmaea in this category. Briggs (1958) and Miller (1958:196) gave the southern distribution as northeastern Florida.) Woods and Inger (1957) concluded that Chologaster did once extend west as far as the Mississippi and that during some period of drought during late or even post-glacial times the habitat dried up. The other species named have apparently been able to make their way back into this area but Chologaster has not done so. Whether this situation is true for $E$, serriferum is even more problematical than for Chologaster.

Geographic Variation-Tables 3-9 give the frequency distribution of the characters examined by river systems. Characters which showed no appreciable variation are presented only in the species comparisons tables. These include: number of anal spines (two except for one Neuse specimen with one); supratemporal canal complete (except one Neuse and two Santee specimens); infraorbital canal complete, pelvic elements I, 5 (except for one Santee specimen with I, 6); opercular and preopercular squamation 100-X-T; coronal pore present; pectoral rays $11-13$, usually 12 ; and branchiostegals $5-7$, usually 6 .

There seem to be two poorly defined groups based on the number of pored lateralline scales (Table 3). Populations in the five northern drainages, Nansemond through Neuse-Ellis Lake, have fewer pored scales ( $\bar{x}: 30.00-32.39)$ than the southern eight populations; Cape Fear through the Altamaha ( $\bar{x}$ :over 33.75$)$. The total lateral-line scales (Table 4) show a similar trend; the northern group has slightly fewer scales than the southern group.

The mode of dorsal spines is eleven except for the Edisto population, which has a mode of ten (Table 5). Seven populations have modal values of 14 rays in the second dorsal fin (Table 5); the Ellis-Neuse population has a mode of 13 , as do also the small samples from the Tar, Combahee, Savannah, Ogeechee, and Altamaha. The modal number of anal rays is seven, except for small samples from the Tar, Savannah, Ogeechee, and Altamaha, where the modes are at six (Table 6). 

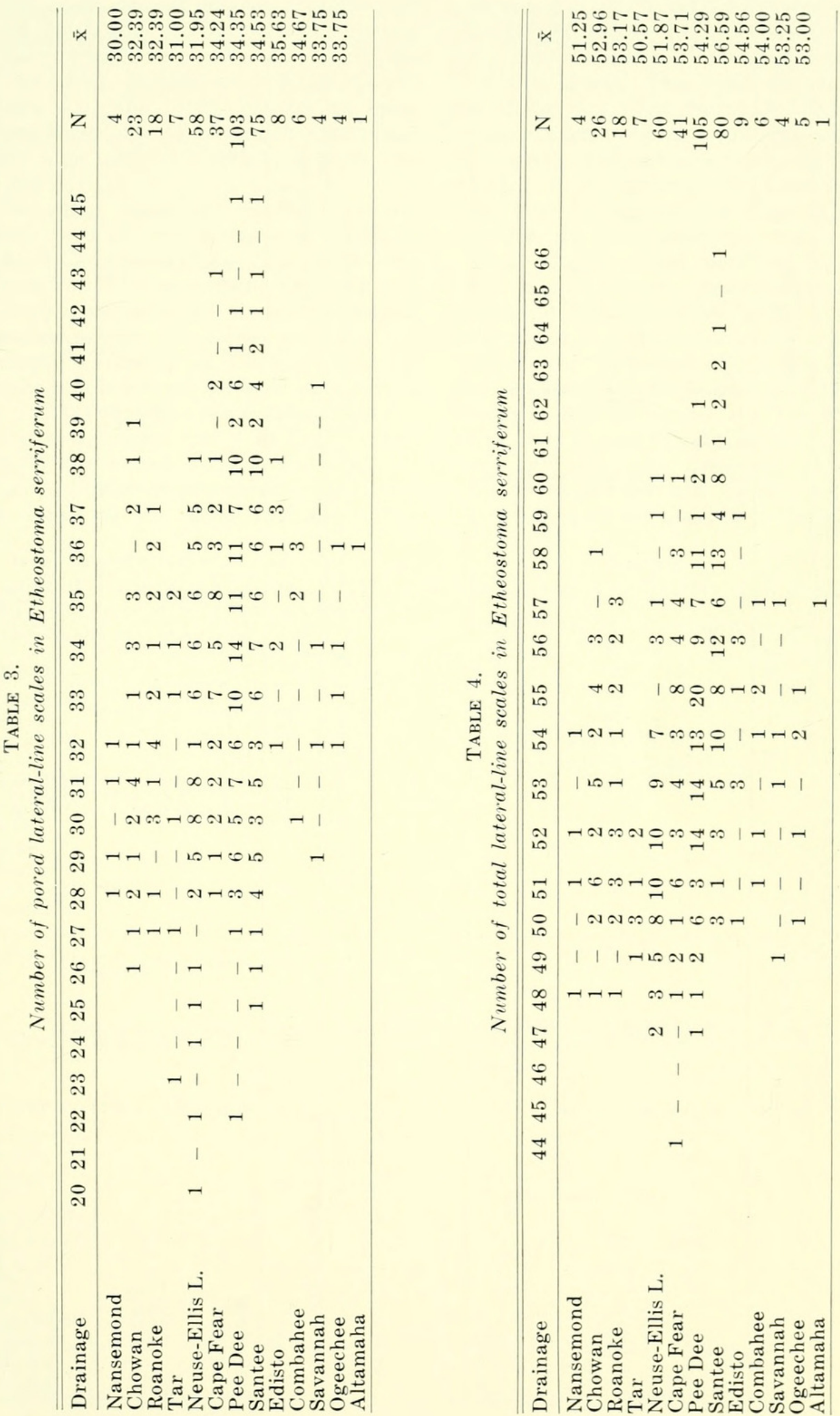

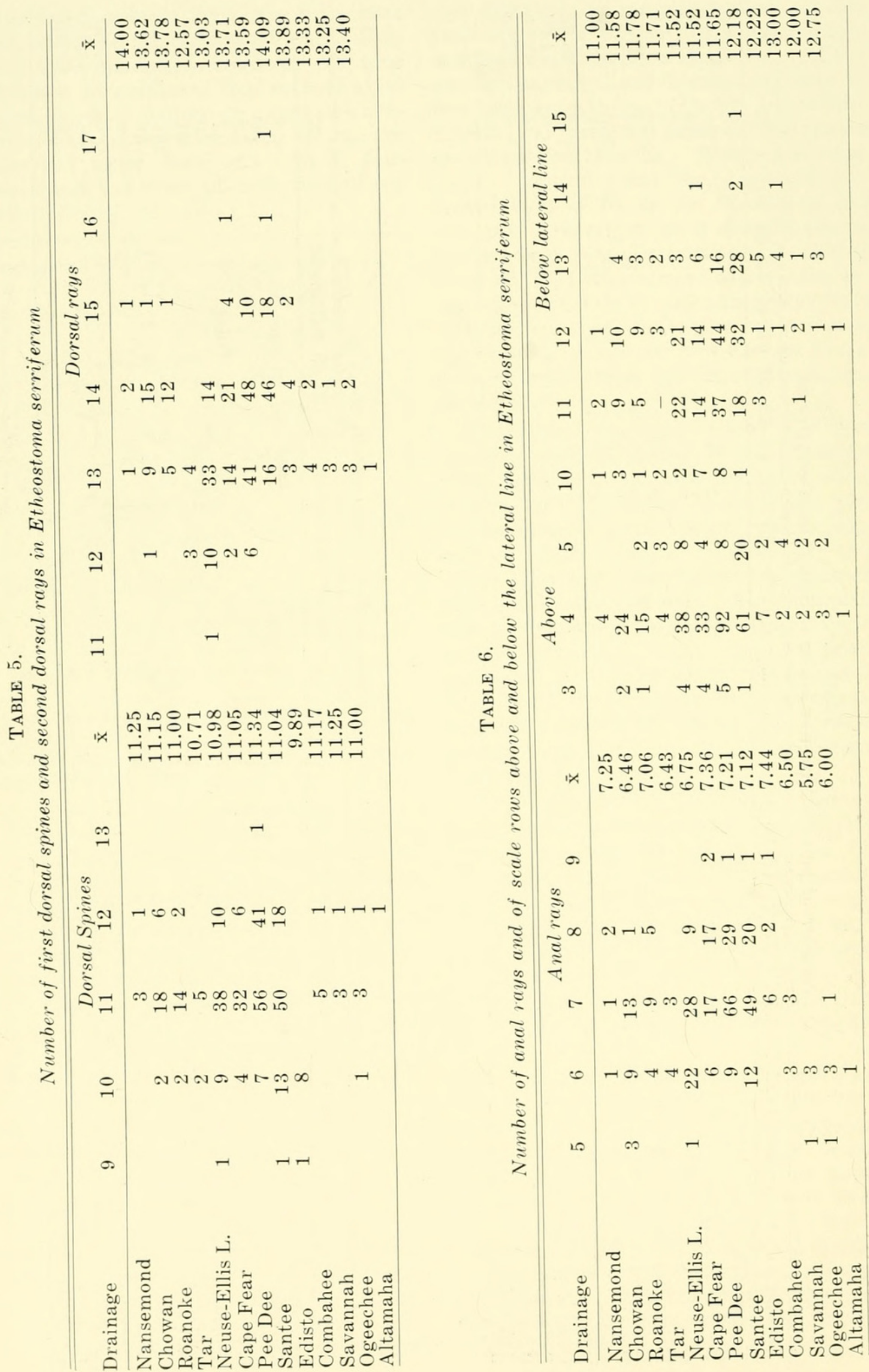
The mode of the number of scale rows above the lateral line is four (range three to five) (Table 6); below the lateral line 12 in most populations (range 10-15) (Table 6). The modal number of infraorbital pores is six, of preoperculomandibular pores nine, and of interorbital pores two (Table 7 ).

The nape, breast and parietal are completely covered with scales with modes of $\mathrm{X}-\mathrm{T}, \mathrm{I}-\mathrm{C}$, and $\mathrm{I} / \mathrm{PX}-\mathrm{C} / \mathrm{T}$, respectively (Table 8 ). The interorbital squamation in E. serriferum shows the greatest geographic variation (Table 9). The northern five drainages (Nansemond, Chowan, Roanoke, Tar, and Ellis-Neuse) have fewer scales in the region ( $\bar{x}: 9.50-13.81)$ than the eight southern drainages ( $\overline{\mathrm{x}}: 17.00-23.25)$. This reduced squamation is correlated with the reduced number of pored and total lateralline scales in the same drainages. This same trend is shown in E. fusiforme, except that the geographic break between the subspecies of E. fusiforme comes between the Cape Fear and Pee Dee, rather than between the Neuse and Cape Fear. The break between subspecies of E. collis also occurs in this region, although I am not yet certain whether it is between the Roanoke and Cape Fear or between the Cape Fear and Pee Dee; the latter seems more likely.

This roughly clinal north-south difference, coupled with the lesser differences in pored and total lateral-line scales, indicates differentiation at the racial level.

Specimens Examined-Complete locality data are listed for the Nansemond drainage (northern limit of range), the Tar drainage (new record), and for the Savannah, Ogeechee, and Altamaha drainages (southern limit of range and new locality records). Other collections are listed by drainage, state,

TABLE 7.

Number of pores in infraorbital (INF), preoperculomandibular (POM), and interorbital (INT) canals in Etheostoma serriferum

\begin{tabular}{|c|c|c|c|c|c|c|c|c|c|c|c|c|}
\hline \multirow[b]{2}{*}{ Drainage } & \multicolumn{5}{|c|}{ INF } & \multicolumn{4}{|c|}{ POM } & \multicolumn{3}{|c|}{ INT } \\
\hline & 4 & 5 & 6 & 7 & 8 & 7 & 8 & 9 & 10 & 0 & 1 & 2 \\
\hline Nansemond & & & 3 & 1 & & & & 4 & & & & 4 \\
\hline Chowan & & 1 & 21 & 4 & & & 2 & 24 & & 1 & 6 & 19 \\
\hline Roanoke & & & 15 & 3 & & & & 18 & & & 1 & 17 \\
\hline Tar & & & 6 & & & & & 5 & 2 & 1 & - & 6 \\
\hline Neuse-Ellis L. & & & 40 & 10 & 1 & & 1 & 47 & 2 & 3 & 9 & 37 \\
\hline Cape Fear & 1 & 2 & 35 & 4 & & & 5 & 35 & & 1 & 7 & 32 \\
\hline Pee Dee & & 2 & 87 & 15 & 1 & 2 & 8 & 93 & & 15 & 20 & 70 \\
\hline Santee & & $\overline{1}$ & 63 & 14 & 3 & & 8 & 71 & 2 & 12 & 19 & 50 \\
\hline Edisto & & & 7 & 2 & & & & 9 & & & 2 & 7 \\
\hline Combahee & & & 4 & 2 & & & & 6 & & & 1 & 5 \\
\hline Savannah & & & 3 & 1 & & & & 4 & & & 2 & 2 \\
\hline Ogeechee & & & 5 & & & & & 5 & & & & 5 \\
\hline Altamaha & & & 1 & & & & & 1 & & & & 1 \\
\hline
\end{tabular}

TABLE 8.

Squamation of nape, breast, and parietal regions in Etheostoma serriferum

\begin{tabular}{|c|c|c|c|c|c|c|c|c|c|c|c|c|}
\hline \multirow[b]{2}{*}{ Drainage } & \multicolumn{3}{|c|}{$\begin{array}{c}\text { Nape } \\
\text { PX }\end{array}$} & \multicolumn{4}{|c|}{ Breast } & \multicolumn{5}{|c|}{ Parietal } \\
\hline & PX-T & $\begin{array}{l}\mathrm{PX} / \\
\mathrm{X}-\mathrm{T}\end{array}$ & $\mathrm{X}-\mathrm{T}$ & $\mathrm{I}-\mathrm{C}$ & $\begin{array}{c}\mathrm{I} / \mathrm{PX}- \\
\mathrm{C} / \mathrm{T}\end{array}$ & $\begin{array}{l}\mathrm{PX}- \\
\mathrm{C} / \mathrm{T}\end{array}$ & $\begin{array}{l}\mathrm{PX} / \\
\mathrm{X}-\mathrm{T}\end{array}$ & $\mathrm{I}-\mathrm{C}$ & $\begin{array}{c}\mathrm{I} / \mathrm{PX}- \\
\mathrm{C} / \mathrm{T}\end{array}$ & PX-T & $\begin{array}{l}\mathrm{PX} \\
\mathrm{X}-\mathrm{T}\end{array}$ & $\mathrm{X}-\mathrm{T}$ \\
\hline Nansemond & 1 & - & 3 & 4 & & & & & 4 & & & \\
\hline Chowan & & & 10 & 13 & 2 & & & & 12 & - & 3 & \\
\hline Roanoke & & & 12 & 12 & 3 & & & & 8 & 4 & 3 & \\
\hline Tar & 2 & 4 & - & 6 & & & & & 6 & & & \\
\hline Neuse-Ellis L. & & 4 & 12 & 18 & 7 & & & & 19 & 5 & 1 & \\
\hline Cape Fear & & 1 & 9 & 13 & 7 & - & 1 & & 10 & 3 & 6 & 3 \\
\hline Pee Dee & & & 12 & 12 & 8 & 2 & & 1 & 11 & 3 & 6 & 1 \\
\hline Santee & & 1 & 10 & 14 & 6 & 1 & & 1 & 8 & 6 & 3 & 3 \\
\hline Edisto & & & 9 & 4 & 5 & & & & 1 & - & 1 & 7 \\
\hline Combahee & & 3 & 3 & 4 & 2 & & & & & 1 & 2 & 3 \\
\hline Savannah & & & 3 & 3 & & & & & 3 & 1 & & \\
\hline Ogeechee & & & 4 & 4 & & & & & & 4 & & \\
\hline Altamaha & & & 1 & & 1 & & & & & & 1 & \\
\hline
\end{tabular}




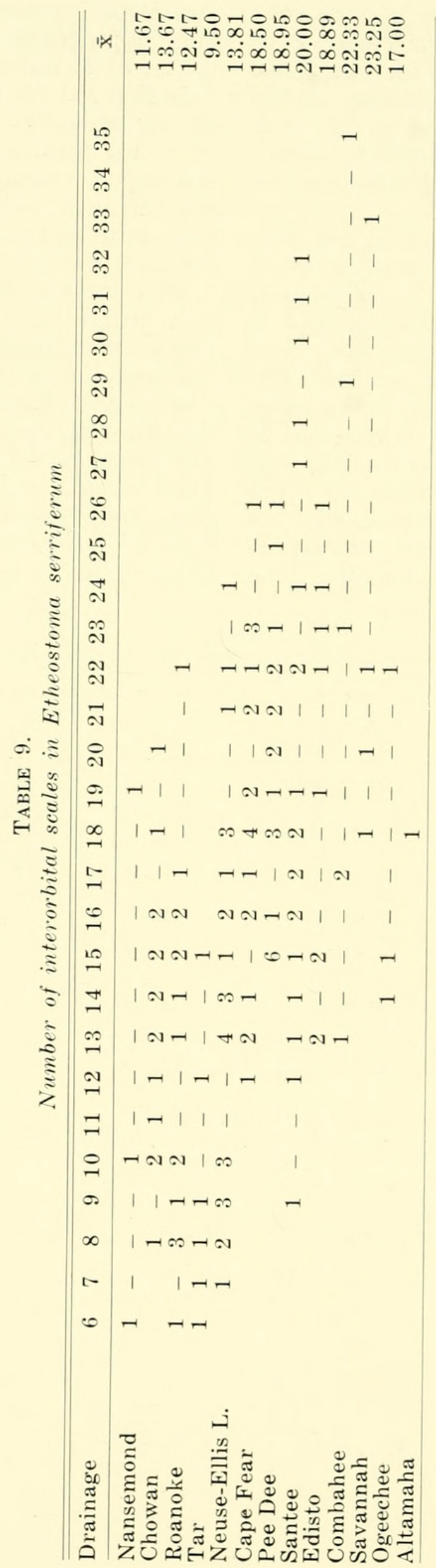


county, and museum number. Complete data on almost all specimens examined are in Collette (1960). A total of 447 specimens from 112 collections was examined.

Nansemond Dr., Va.-Nansemond Co. : CU 9920 (4, 34-41); trib. of Nansemond R. 2 mi $\mathbf{N}$ of Suffolk on US $460^{\circ}$ March 29. 1941

Chowan Dr.. 26 specimens. Va.-Dinwiddie Co. CU 11781. Greensville Co.: CU 20623, 29976. Sussex Co.: CU 16881. N.C.-Gates Co.: CU $9 \$ 92,30141$.

Roanoke Dr. 18 specimens. N.C.-Bertie Co. CU 29979. Martin Co.: CU 25241, 29981. Northhampton Co.: CU 17017.

Tar Dr.. N.C.-Edgecomb Co.: USNM 179732 $(1,26)$ : Fishing Cr., Tarboro: Sept. 19.1959. Nash Co.: DU uncat. $(4,42-46)$ : Little Sapony Cr. $3.6 \mathrm{mi}$. W of Nashville on US 64: June 1 , 1950 . DU uncat. $(2.43-46)$ : Little Sapony Cr. $2.3 \mathrm{mi}$. S of Nashville on NC 58: June 1,1950 . Neuse-Ellis Lake Dr., 94 specimens, N.C.Carteret Co. : DU uncat. Craven Co.: USNM 53041 : CU 9878, 9814. 16821. 29982. 29984; out of UMMZ 161986: DU uncat. Johnston Co. ISNM 179730. Lenoir Co: CD 9723, 9748 On slow Co. : CU 9752. 30573. Pitt Co.: DU uncat Wayne Co.: CU 33105. Wilson Co.: CU 10636 Wake Co.: UMMZ 107053 (1. 52): Buffalo Cr. Wendell: Nov. 19, 1925: holotype of Hololepis serrifer

Cape Fear Dr., 60 specimens. N.C.-Bladen Co. CU 34529. Brunswick Co.: CT 4090. Cumberland Co: CU 14100.30134 Duplin Co. : CU 30557 Durham Co.: DU uncat. : CU 34517. Hoke Co. CU 15614. 25948. 26109. 33102. Moore Co.: CU 25262, 32170: USNM 93193. New Hanover Co. USVI 9313293133 \&6163 paratypes of Hololepi serrifer. USNM 170975. 94348. Pender Co.: CU 29986,30052 . 33103, 33104.

Pee Dee Dr.. 134 specimens, N.C.-Moore Co. DU uncat. : CU 11147, 32706, 35134. Richmond Co.: CU 19571. Richmond-Scotland cos. : TG 460 Scotland Co. : CU 25965. S.C.-Chesterfield Co. CU 15636. 29989. 29990. Clarendon Co. : CU 15202 . 15359. Darlington Co. : CU 15721, 28206. 30122. Dillon Co.: CU 15867. Florence Co.: CL 1918. Lee Co. : CU 28220. Marion Co. : CU 25225. Marlboro Co. : ANSP 61027-9. Sumter-Lee $\cos$. CI 15225

Santee Dr.. 80 specimens, S.C.-Calhoun Co. CU 35051. Kershaw Co. : CU 35042, 35061. 35056 35059. 35060. 35064. 3505. 35047. Lexington Co. CU 35058 35050 35063 Richland Co. CU $35049.35054 .35046,35057,35043,35053$ $\begin{array}{lll}\text { CU } 35049.35054,35046, & 35057 . \\ 35044.35062,35052, & 35048, & 35045 .\end{array}$

Edisto Dr.. 9 specimens, S.C.-Aiken-Lexington cos. : CU 35041. Bamburg Co. : CU 35065. 35066. Combahee Dr. 6 specimens. S.C.-Allendale Co. CU 15322. Bamburg Co.: CU 19194. Hampton Co. : CU 32672. Jasper Co.: CU 32661.

Savannah Dr.. Ga.-Richmond Co.: CU 30321 (1.39) : Boggy Gut Cr., trib. of Brier Cr.. 22.5 mi. SW of Augusta on US 1: March 24, 1950. Sereven Co.: CU 30621 (2, 45): trib. of Savannah R., $12.9 \mathrm{mi}$. SW of Savannah R.. Dec. 28,1949 UG 240A $(1,50)$; Blue Sp.. Black Cr.. 6 mi. NE of Newington: 'Jan. 31. 1952. Oggeechee Dr.. Ga.-Candler Co.: UG 152 (2. 40 44) : March 24-25. 1950 and $\mathrm{UG} 152 \mathrm{~A}(1,30)$ March 24-25, 1950 and out of UG $152 \mathrm{~B} \quad(1,29)$ Aug. 8, 1958: Canoochee R. 4 mi. W of Metter on Ga 46. Emmanuel Co.: UG 554 (1.44) : Canoochee R., $8 \mathrm{mi}$. S of Twin City ; Aug. 8. 1958.

Altamaha Dr.. Ga.-Telfair Co. : CU 17257 (1, 45) : Little Öcmulgee R., $1.2 \mathrm{mi}$. N of McRae on US 319 ; March 25, 1950.

\section{Etheostoma gracile (Girard)}

Boleosoma gracile-Girard, 1859:103 (original description)

Poecilichtbys butlerianus-Hay, 1882:6162 (original description).

Poecilichthys palustris-Gilbert, 1884: 209-210 (original description).
Boleichthys fusiformis-Forbes, 1907: $281 ; 287,291-292$, map XV (in part) (ecology, Ill.); Forbes, 1909:390, 401, 403, 417, 421, 425, 432, tables I-VI, map XCVIII, pl. XXV (in part) (ecology and distribution, Ill.); Forbes and Richardson, 1909, 1920:315, map 98 (in part) (description and distribution, Ill.); Forbes, 1914:17, map 48 (in part), fig. 30 (distribution in Ill., not given by Hubbs and Cannon, 1935, in their synonymy); Thompson and Hunt, 1930:33, 45 (ecology, Champaign Co., Ill.); Driver, 1942:285 (in key, in part)

Hololepis fusiformis-Luce, 1933:120 (Ill.); O'Donnell, 1935:489-490 (in part) (III.) .

Hololepis gracilis-Hubbs and Cannon, 1935; Baker, 1939a:36-37 and 1939b:45 (Reelfoot Lake, Tenn.); Kuhne, 1939:93, fig. 63: Lamb, 1941:45 (San Jacinto R., Tex.); Fowler, 1945:40 (Ala., Pearl, Trinity, Nueces r.), 369-370 (La.); Gerking, 1945:16, 95 (distribution in Ind.); Hubbs, 1946:39 (Okla.); Moore and Poole, 1948: 37 (McCurtain Co., Okla.); Baughman, 1950:247 (Tex.); Hall, 1951:17 (Lake Murray, Carter and Love cos., Okla.) ; Cross and Moore, 1952:409 (Poteau River in Okla. and Ark.).

Boleichthys gracilis-Blatchley, 1938:9899 (Ind.); Driver, 1950:298 (in key).

Boleichthys fusiformis gracilis-Schrenkeisen, 1938:235.

Etheostoma gracile-Hubbs, 1952:486 (Tex.); Moore, 1952:11 (Okla.); Jurgens and Hubbs, 1953:4 (Tex.); Knapp, 1953: 126, 128 (Tex.), fig. 166; Cross, 1954:478479 (Kan.); Bailey and Gosline, 1955:20, 44 (number of vertebrae); Gerking, 1955: 84 (Ind.); Gunning and Lewis, 1955:557 (IIl.); Linder, 1955a:28-29 (in aquaria); Linder, 1955b:176 (Blue R., Okla.); Eddy, 1957:219, fig. 545; Hubbs, 1957a:9 (Tex.); Hubbs, 1957b:93, 98 (distribution in Tex.); Moore, 1957:197-198; Bridges, 1958:3, 9 (poisoned in Ill. farm ponds); Hancock and Sublette, 1958:49 (La.); Hubbs, 1958: 11 (Tex.); Blair, 1959 (Okla., distribution, ecology); Boudreaux, Strawn, and Callas, 1959:8, 10 (poisoned in Tex.): Cook, 1959: 35, 38, 200, 207-208 (Miss.); Hubbs, 1959: 50, 52 (artificial hybridization with Percina sciera and Etheostoma proeliare); Riggs and Bonn, 1959:167 (Lake Texoma, Okla.); Collette, 1961:2051. 
Types-Hubbs and Cannon (1935) selected USNM 1328, $36 \mathrm{~mm}$ SL, as lectotype of Boleosoma gracile; from Rio Seco, near Fort Inge, Texas, collected by Dr. Kennerly. They listed two extant paratypes: MCZ 113, from the lectotype locality, and USNM 1329, from Leona River, near Fort Inge, Texas, also collected by Dr. Kennerly. The holotype of Poecilichthys butlerianus is USNM 32224 , $43 \mathrm{~mm} \mathrm{SL}$, from a pool along the Big Black River, near Vaughan's Station, Yazoo Co., Mississippi. Hubbs and Cannon selected USNM 34983, $30 \mathrm{~mm}$ SL, from Switz City Swamp, Indiana, as lectotype of Poecilichthys palustris.

Diagnosis-Similar to E. zoniferum in usually having: ten preoperculomandibular pores; interorbital pores absent; naked breast and nape; and green vertical bars on the sides in life. Differs from E. zoniferum primarily in having the infraorbital canal complete with eight pores. Also differs in having more anal rays ( $\mathrm{x}: 6.7)$, more scales above the lateral line (mode: $4, \overline{\mathrm{x}}: 3.7$ ) and below the lateral line (mode:9, $\overline{\mathrm{x}}: 8.9$ ). Maximum size of males $43.4 \mathrm{~mm} \mathrm{SL}$ and females $46.4 \mathrm{~mm}$ (TNHC 578, Neches River, Tex.).

Coloration-In the non-breeding female, groups of medium sized melanophores are present on the membrane at the base of the first dorsal fin and small melanophores are found on the distal margin of the membranes between the last three dorsal spines. Medium melanophores are scattered on the membranes of the second dorsal fin and do not form the rectangular blotches present in $E$. saludae and E. collis. The pectoral fin is clear, but a few small melanophores outline the rays. The pelvic fin varies from clear to having a few melanophores on the last rays and on the membranes between them. The caudal is barred. The belly and breast are immaculate, or have a few scattered melanophores. There are a few scattered medium melanophores on the cheek. The preorbital and postorbital bars are prominent; the supraorbital and suborbital are faint. The pored portion of the lateral line usually is light, although some specimens have a few melanophores under the scales and/or along their distal edge. The median basi-caudal spot is usually prominent. Sometimes there are faint spots at the upper and lower bases of the caudal fin. The pattern of the sides varies within, as much as between, populations. Some specimens have no lateral blotches while others show, more or less clearly, eight to ten which alternate with the dorsal saddles and give the fish a variegated pattern. The eight to eleven dorsal saddles connect at the level of the lateral line and isolate central light areas. There is no pigment on the genital papilla or in an area around it. Figure 4 compares a breeding female $E$. gracile with E. zoniferum.

The pectoral and caudal fins, dorsal body surface, and genital papilla in the nonbreeding male are colored like the female. The dorsal fins are darker than those of the female. The anal fin is covered with large melanophores which tend to fuse. The pelvic fins have many melanophores between the last two rays and fewer between the anterior rays. The breast and belly usually are covered with small melanophores. The orbital bars and lateral blotches appear less prominent in the non-breeding male because the cheek and sides are darker than in the female. The pored portion of the lateral line has more pigment on the distal than on the proximal parts of some scales. The non-pigmented area around the genital papilla is smaller than in the females and appears more prominent, because of the darker venter.

In the breeding male, the pectoral and caudal fins, pored portion of the lateral line, orbital bars, basi-caudal spots, sides, dorsal surface, and genital papilla are colored like the non-breeding male; the other regions are darker. Most of the basal third of the first dorsal fin is solid black. The second dorsal and anal fins show a lesser tendency toward melanophore fusion. The pelvic fins, breast, and belly are densely speckled with small melanophores. The cheek is usually darker. Figure 4 compares the pattern of breeding male E. gracile and E. zoniferum.

In life, E. gracile and E. zoniferum differ from the other species of the subgenus Hololepis in having vertical green bars on their sides. Males of both species have a submarginal red-orange band in the first dorsal fin which intensifies at breeding season. Hubbs and Cannon (1935) quoted Jordan and Evermann (1896) to the effect that the spinous dorsal in life is usually bright blue. This is an obvious reference to the 
color of a breeding male Etheostoma exile which Jordan confounded with E. gracile.

Breeding Tubercles-At the height of the breeding season, moderately large tubercles are present on the distal half of the anal rays (Fig. 1h), the distal three-quarters of the lower side of the pelvic spine and rays (Fig. 1k), and in two rows of four tubercles on each ramus of the lower jaw (Fig. $1 \mathrm{~m})$. The earliest that tubercles were ob-
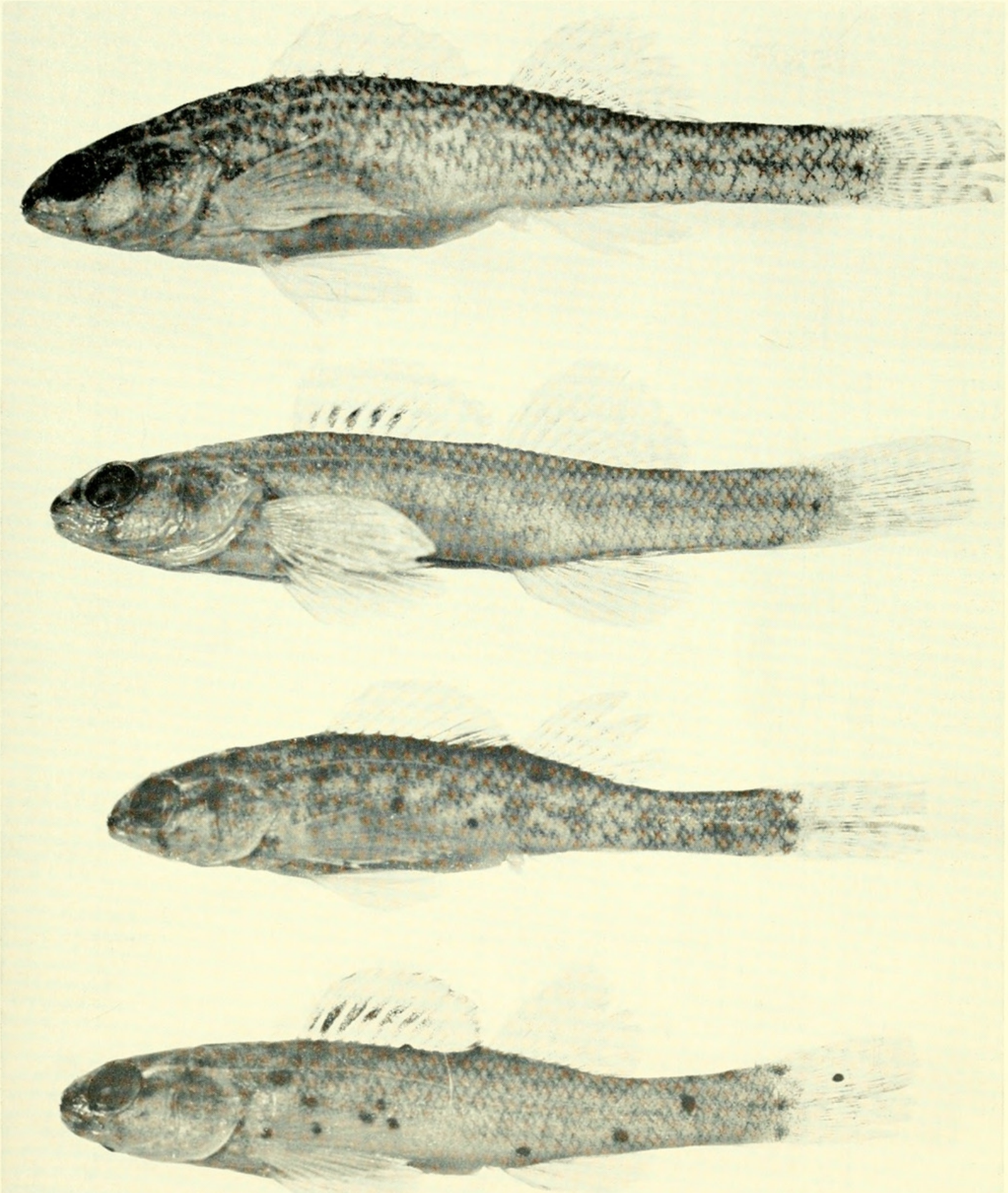

Figure 4. Breeding patterns of Etheostoma gracile and E. zoniferum. (from top to bottom) E. gracile female; UMMZ 161034; $42.7 \mathrm{~mm}$; Tenn., Haywood Co., OhioArkansas dr.; Apr. 2, 1949. E. gracile male; TNHC 2957; 38.7 mm; Tex., Montgomery Co., San Jacinto dr.; Mar. 7, 1952. E. zoniferum female; UMMZ 163758; $35.3 \mathrm{~mm}$; Ala., Greene Co., Tombigbee dr.; Apr. 16, 1941. E. zoniferum male; UMMZ 163758; $36.5 \mathrm{~mm}$; Ala., Greene Co., Tombigbee dr.; Apr. 16, 1941. (Photographs by Douglass M. Payne) 
136

Tulane Studies in Zoology

Vol. 9

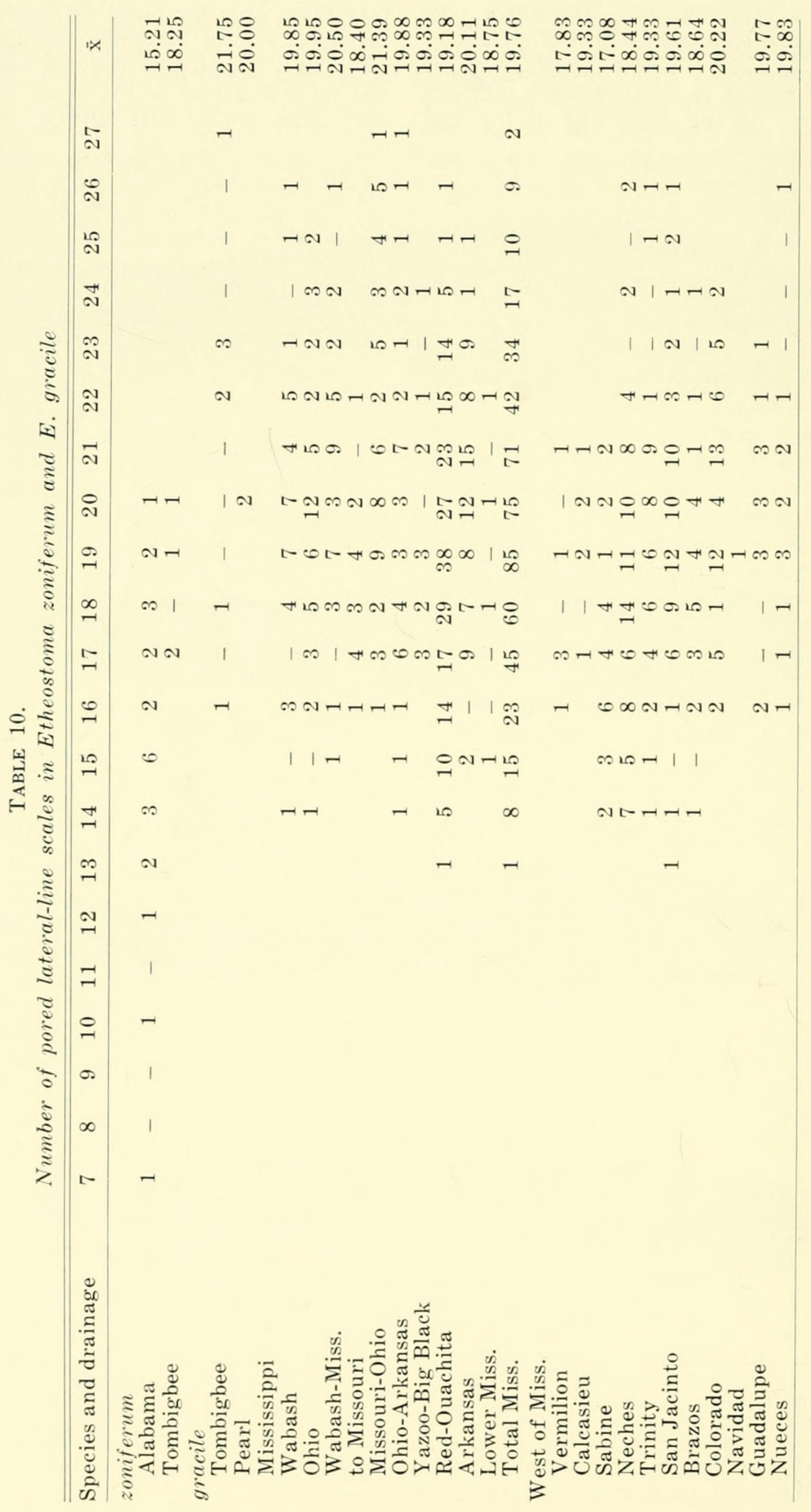


served was February 19 (TNHC 4994; 1, $39.4 \mathrm{~mm}$; Red River, Tex.). The latest that breeding tubercles were found was April 19 (UK 2418; 3, 33.6-39.6 mm; Red River, Okla.). The maximum development appears to take place in mid-March in Texas, where collections taken from throughout the year have been examined.

Genital Papilla-The genital papilla of the breeding female is a moderately elongate tube with a somewhat blunt end. A 36.7 $\mathrm{mm}$ female (UMMZ 162897) taken from the Yazoo River of Mississippi has a genital papilla which is $1.7 \times 0.7 \mathrm{~mm}$. Figure $1 \mathrm{c}$ shows the genital papilla of a $40.4 \mathrm{~mm}$ female taken on Mar. 7 (TNHC 2750, San Jacinto R.). There is a bulbous enlargement of the base of the papilla in some specimens.

Development-As in Etheostoma fusiforme, the supratemporal canal is incomplete in juveniles and the two ends of the canal fuse with age. A series of 25 Mississippi specimens (USNM 129113), ranging from 12.5 to $20.7 \mathrm{~mm}$, all have incom- plete supratemporal canals. Again, as in E. fusiforme, the transition period from incomplete to complete takes place at different sizes in different populations. This is shown by two groups of collections (UMMZ 107048, Missouri to Ohio Drainage; USNM 172570, 172495, 172523, 172481, 172576, and 172560 from the Red River Drainage). Of the thirty specimens in UMMZ 107048, five $(19.4-21.0 \mathrm{~mm})$ have incomplete supratemporal canals, while the other 25 (26.7$34.7 \mathrm{~mm}$ ) have complete canals. Eight of the Red River specimens (14.6, 14.7, 16.1, $16.5,16.5,17.1,17.4,23.4 \mathrm{~mm}$ ) have incomplete canals while the larger specimens (17.7, 17.7, 18.7, 19.1, 25.5, 27.5, 34.1, $35.4 \mathrm{~mm}$ ) have complete canals.

Development of the pored lateral-line scales is also very similar to that in E. fusiforme (q.v.) as shown in USNM 129113. Eleven specimens $(18.1-20.7 \mathrm{~mm})$ have from 10 to 16 pored lateral-line scales which is below the normal range of 13-27, mean 19.5 (Table 39). Six specimens (17.4-

TABLE 11.

Number of total lateral-line scales in Etheostoma zoniferum and E. gracile

\begin{tabular}{|c|c|c|c|c|c|c|c|c|c|c|c|c|c|c|c|c|c|}
\hline Species and drainage & 40 & 41 & 42 & 43 & 44 & 45 & 46 & 47 & 48 & 49 & 50 & 51 & 52 & 53 & 54 & 55 & $\overline{\mathrm{x}}$ \\
\hline \multicolumn{18}{|l|}{ zoniferum } \\
\hline Alabama & & 2 & 1 & - & - & 2 & 1 & 6 & 6 & 3 & 1 & - & 1 & 1 & & & 47.17 \\
\hline Tombigbee & & & & & & & & & 1 & 2 & - & 1 & & & & & 49.25 \\
\hline \multicolumn{18}{|l|}{ gracile } \\
\hline Tombigbee & & & & & & & & & & 1 & 1 & 2 & 1 & 1 & & & 51.00 \\
\hline Pascagoula & & & & & & & & & & 1 & & & & & & & \\
\hline Pearl & & & & & & & & 1 & 1 & & & & & & & & 47.50 \\
\hline \multicolumn{18}{|l|}{ Mississippi } \\
\hline Wabash & & & & & 1 & 4 & 5 & 7 & 4 & 5 & 6 & 3 & 2 & & & & 48.03 \\
\hline Ohio & & & 1 & - & 3 & 3 & 6 & 7 & 7 & 7 & 4 & 3 & 1 & - & 2 & & 47.86 \\
\hline Wabash-Miss. & & & 1 & 1 & 2 & 4 & 6 & 8 & 4 & 5 & 2 & 2 & & & & & 46.97 \\
\hline to Missouri & & & & & 1 & 1 & 1 & 3 & 1 & 1 & 2 & 3 & - & 1 & & & 48.50 \\
\hline Missouri-Ohio & & & & 1 & 3 & 2 & 5 & 4 & 7 & 6 & 4 & 10 & 1 & 5 & 1 & & 48.86 \\
\hline Ohio-Arkansas & & & 2 & 2 & 3 & 1 & 3 & 4 & 3 & 6 & 3 & 4 & 1 & & & & 47.41 \\
\hline Yazoo-Big Black & & 1 & - & - & 2 & 3 & 2 & 3 & 1 & - & - & 1 & & & & & 45.85 \\
\hline Red-Ouachita & 1 & 3 & 5 & 7 & 7 & 21 & 24 & 40 & 35 & 18 & 19 & 11 & 6 & 3 & - & 1 & 47.31 \\
\hline Arkansas & & & & & 2 & 5 & 4 & 6 & 15 & 12 & 6 & 9 & 4 & 2 & & & 48.62 \\
\hline Lower Miss. & & 1 & - & - & - & - & 1 & 2 & & & & & & & & & 45.25 \\
\hline Total Miss. & 1 & 5 & 9 & 11 & 24 & 44 & 57 & $8 \overrightarrow{4}$ & 77 & 60 & 46 & 46 & 15 & 11 & 3 & 1 & 47.70 \\
\hline \multicolumn{18}{|l|}{ West of Miss. } \\
\hline Vermilion & & & & & & 1 & 3 & - & 1 & 1 & & & & & & & 46.67 \\
\hline Calcasieu & & & 1 & 1 & - & 1 & 2 & - & - & - & 1 & & & & & & 45.33 \\
\hline Sabine & & 2 & 1 & 1 & - & 3 & 5 & 5 & 2 & 1 & 1 & 1 & - & 1 & & & 46.35 \\
\hline Neches & 1 & 4 & 6 & 9 & 3 & 11 & 8 & 12 & 16 & 5 & 3 & 1 & & & & & 45.77 \\
\hline Trinity & & 1 & 2 & 2 & 1 & 8 & 4 & 6 & 11 & 3 & - & 1 & 1 & 1 & & & 46.63 \\
\hline San Jacinto & 1 & - & 2 & 3 & 5 & 6 & 8 & 10 & 10 & 6 & 1 & 3 & 4 & 1 & - & 1 & 47.11 \\
\hline Brazos & & & & & & 2 & 3 & 3 & 2 & 3 & 2 & 3 & 2 & & & & 48.45 \\
\hline Colorado & & & & & & 3 & - & 1 & 3 & 6 & 12 & 9 & 8 & 7 & 1 & & 50.40 \\
\hline Navidad & & & & & & & & 1 & & & & & & & & & \\
\hline Guadalupe & & & & & 1 & - & 1 & - & 5 & 1 & 2 & - & 1 & & & & 48.27 \\
\hline Nueces & & & & & & & & & 2 & 1 & 1 & 3 & 3 & 2 & & & 50.83 \\
\hline
\end{tabular}




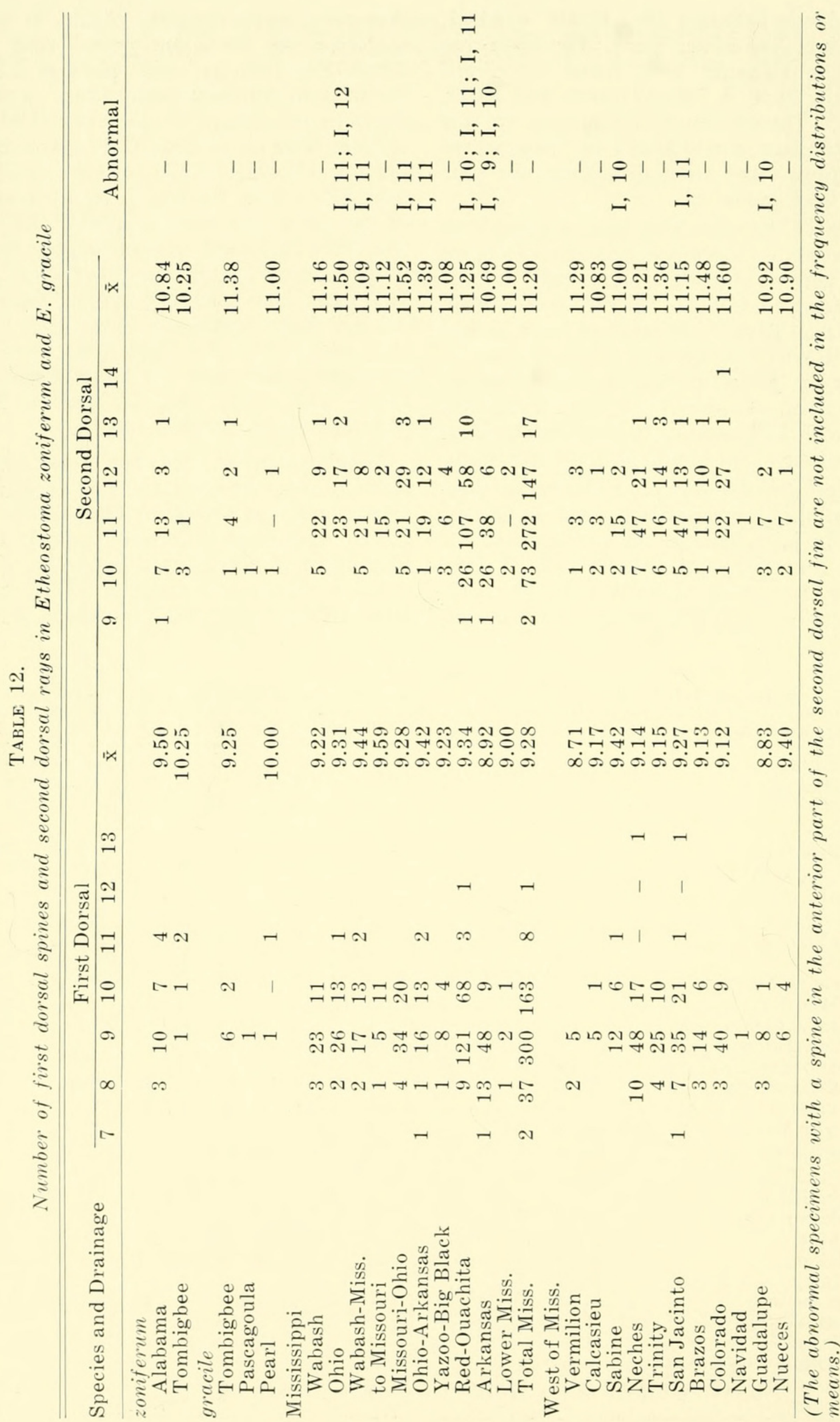


TABLE 13.

Number of anal rays in Etheostoma zoniferum and E. gracile

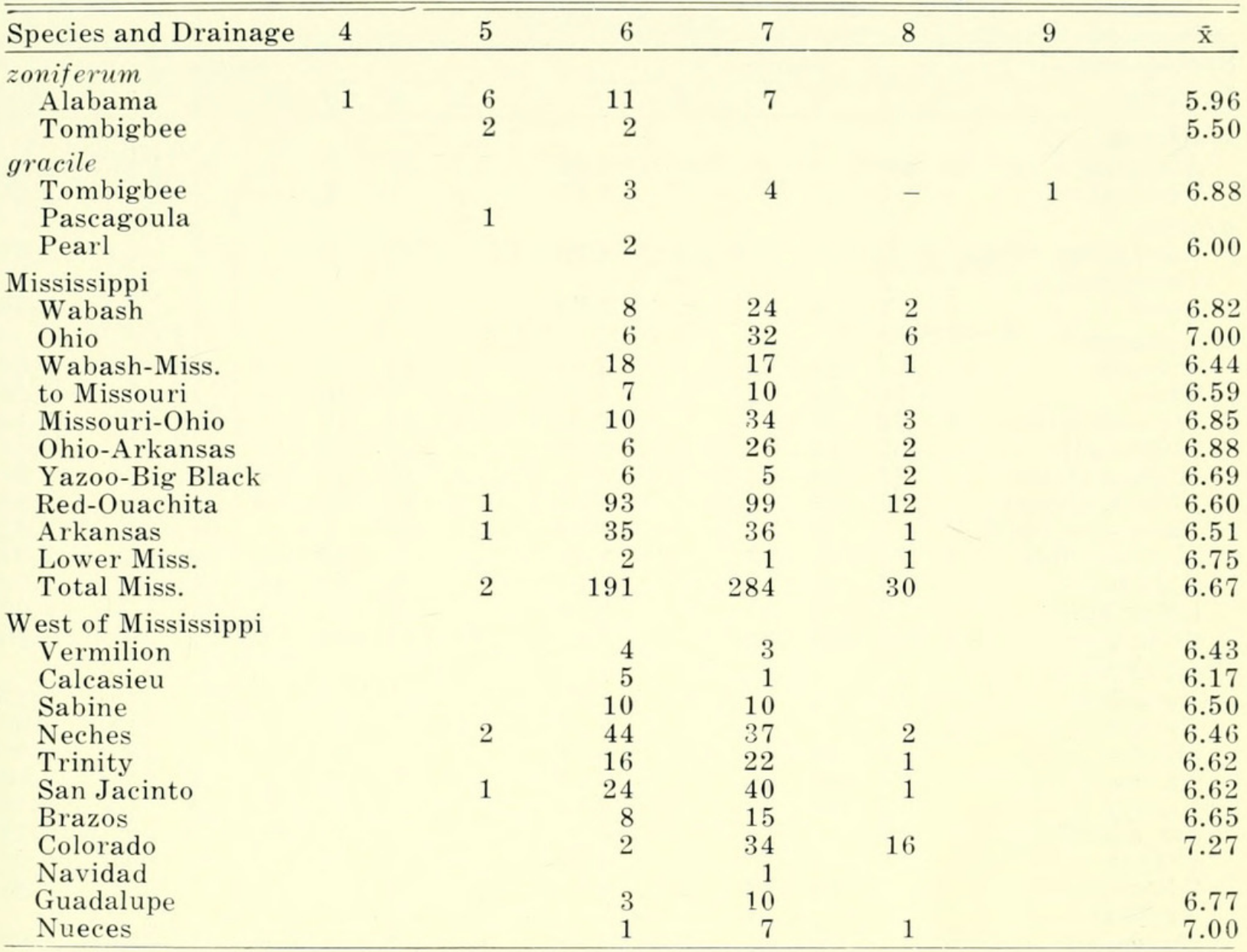

$18.0 \mathrm{~mm}$ ) have $0-13$ pored scales. Five specimens $(15.9-17.1 \mathrm{~mm})$ have either one or no pored scales, while the three smallest specimens (12.5-14.9 $\mathrm{mm}$ ) have no pored scales. From $18.0 \mathrm{~mm}$ down, all the specimens in this collection have ridges on some of the scales in the lateral line posterior to the completely pored scales. These ridges grow out from the scale and then meet over the center of the scale forming the pored lateral-line scale.

The development of squamation was also studied in this collection. The smallest $(12.5 \mathrm{~mm})$ specimen has scales on the sides of the caudal peduncle and extending forward along the lateral line. Scales are absent on the ventral part of the caudal peduncle, nape, pectoral fin base, opercle, preopercle, belly, and dorsally and ventrally from the lateral line anterior to the first dorsal fin origin. At $14.6 \mathrm{~mm}$, a few imbedded scales appear on the opercle and squamation of the ventral half of the belly begins. Between 19.0 and $20.7 \mathrm{~mm}$, squamation of the oper- cle, preopercle, and the posterior part of the belly is complete. Scales develop on the nape and the base of the pectoral fin some time after this.

The most interesting developmental feature that can be studied in this collection is the infraorbital canal. In adult E. gracile, it is complete with eight pores. In all 25 specimens in USNM 129113, this canal is incomplete. The $12.5 \mathrm{~mm}$ specimen has two pores in the anterior portion of the canal and only an open groove in the posterior portion of the canal. Most of the middle nineteeen specimens (14.6-19.0 mm) have three pores in the anterior portion and two in the posterior $(2+3$ as in E. fusiforme $)$ but there are also two specimens with $3+3$ and two with $2+4$. The largest five specimens in the collection have $3+4$. In addition, the $20.7 \mathrm{~mm}$ specimen has a groove extending between the anterior and posterior portions of the canal. This groove has lateral ridges along it which will roof over the canal in a manner similar to the development of the 
TABLE 14.

Number of scale rows above and below the lateral line in Etheostoma zoniferum and E. gracile

\begin{tabular}{|c|c|c|c|c|c|c|c|c|c|c|c|c|c|}
\hline \multirow{2}{*}{$\begin{array}{l}\text { Species and } \\
\text { Drainage }\end{array}$} & \multicolumn{6}{|c|}{ Above } & \multicolumn{7}{|c|}{ Below } \\
\hline & 2 & 3 & 4 & 5 & 6 & $\overline{\mathrm{x}}$ & 7 & 8 & 9 & 10 & 11 & 12 & $\overline{\mathrm{x}}$ \\
\hline \multicolumn{14}{|l|}{ zoniferum } \\
\hline Alabama & & 20 & 5 & & & 3.20 & 5 & 11 & 7 & 2 & & & 8.24 \\
\hline & & & & 8.25 \\
\hline $\begin{array}{l}\text { gracile } \\
\text { Tombigbee }\end{array}$ & & 8 & & & & & & & & & & & \\
\hline Pascagoula & & 1 & & & & 3.00 & & $\begin{array}{l}3 \\
1\end{array}$ & 4 & & & & 8.57 \\
\hline Pearl & & 1 & 1 & & & 3.50 & & 1 & 1 & & & & 8.50 \\
\hline \multicolumn{14}{|l|}{ Mississippi } \\
\hline Wabash & & 14 & 21 & 1 & & 3.64 & & 10 & 19 & 6 & 2 & & 9.00 \\
\hline Ohio & & 19 & 14 & 1 & & 3.47 & & 9 & 16 & 9 & & & 9.00 \\
\hline Wabash-Miss. & 1 & 23 & 8 & & & 3.22 & 1 & 11 & 17 & 5 & & & 8.76 \\
\hline to Missouri & & 2 & 14 & & & 3.88 & & 7 & 9 & & & & 8.56 \\
\hline Missouri-Ohio & & 22 & 29 & 4 & & 3.67 & 4 & 25 & 17 & 7 & 1 & & $\begin{array}{l}8.00 \\
8.56\end{array}$ \\
\hline Ohio-Arkansas & & 20 & 13 & & & 3.39 & 1 & 10 & 13 & 8 & & & 8.88 \\
\hline Yazoo-Big Black & & 7 & 5 & 1 & & 3.54 & & 4 & 7 & 1 & 1 & & 8.92 \\
\hline Red-Ouachita & 1 & 71 & 121 & 13 & & 3.71 & 10 & 56 & 80 & 45 & 10 & 1 & 8.96 \\
\hline Arkansas & & 28 & 33 & 2 & & 3.59 & & 20 & 30 & 14 & 4 & & 9.03 \\
\hline lower Miss. & & 3 & 1 & & & 3.25 & & 2 & - & 1 & 1 & & 9.25 \\
\hline total Miss. & 2 & 209 & 259 & 22 & & 3.61 & 16 & 154 & 208 & 96 & 19 & 1 & 8.90 \\
\hline \multicolumn{14}{|l|}{ West of Miss. } \\
\hline Vermilion & & 1 & 2 & & & 3.67 & & 1 & 2 & & & & 8.67 \\
\hline Calcasieu & 1 & 4 & & & & 2.80 & 1 & 2 & 2 & & & & 8.20 \\
\hline Sabine & & 5 & 15 & & & 3.75 & & 3 & 13 & 4 & & & 9.05 \\
\hline Neches & & 24 & 51 & 6 & & 3.78 & 1 & 26 & 39 & 12 & 1 & 1 & 8.86 \\
\hline Trinity & & 3 & 29 & 9 & & 4.15 & & 5 & 15 & 15 & 4 & & 9.46 \\
\hline San Jacinto & & 16 & 39 & 10 & & 3.91 & & 13 & 26 & 18 & 2 & & 9.15 \\
\hline Brazos & & 10 & 11 & & & 3.52 & & 10 & 9 & 3 & & & 8.68 \\
\hline Colorado & & 6 & 32 & 13 & 1 & 4.17 & 1 & 15 & 28 & 8 & & & 8.83 \\
\hline Navidad & & & $\begin{array}{r}1 \\
10\end{array}$ & 1 & & & & $\begin{array}{l}1 \\
3\end{array}$ & 6 & 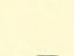 & & & \\
\hline $\begin{array}{l}\text { Guadalupe } \\
\text { Nueces }\end{array}$ & & 1 & $\begin{array}{r}10 \\
5\end{array}$ & $\begin{array}{l}1 \\
5\end{array}$ & & $\begin{array}{l}4.09 \\
4.36\end{array}$ & & $\begin{array}{l}3 \\
1\end{array}$ & $\begin{array}{l}6 \\
4\end{array}$ & $\overline{4}$ & $\begin{array}{l}2 \\
1\end{array}$ & 1 & $\begin{array}{l}9.09 \\
9.73\end{array}$ \\
\hline
\end{tabular}

pored lateral-line scales. It will be noted that development in the infraorbital canal proceeds from the pore just behind the nostril posteriorly and from the junction with the lateral canal anteriorly.

Habitat-Data on 50 University of Texas collections made available by Clark Hubbs show that most E. gracile were found in slow, moderately flowing, or quiet waters (Table 17). The type of water was about equally divided between muddy and/or murky, clear, and brown. No aquatic vegetation was present at about half the collection localities and most of the rest had only slight to moderate amounts (Myriophyllum, Potamogeton, Typha, green algae, and water lilies). Aquatic vegetation was abundant at only four localities and was composed of Ceratophyllum, rushes, and filamentous algae. The number of times each of the six elements in the bottom types-mud and/or slit, sand, detritus, gravel, clay, and bedrock -were present is given in Table 17. The most often found bottom type was mud and/or silt (present at $77 \%$ of the localities).

All E. gracile in 12 collections I made in Illinois, Indiana, Tennessee, Oklahoma, and Texas, were taken from ponds, swamps, or backwaters. Eight localities lacked aquatic vegetation. One had slight amounts of algae, another some emergents, and a third a few aquatics. The north end of Reelfoot Lake, Tennessee, had abundant aquatic vegetation, including Cabomba, Azolla, Ceratophyllum, and Ludwigia. The water was white and turbid at 11 localities; turbid and slightly stained brown in the other. At all localities, E. gracile was taken over mud, silt or detritus.

Blatchley (1938) reported the habitat of $E$. gracile in Indiana as lowland swamps and bayous; Gerking (1945) as sluggish, turbid water on a rather firm bottom of sand (or sand and mud). In Illinois, O'Donnel (1935) reported that E. gracile pre- 


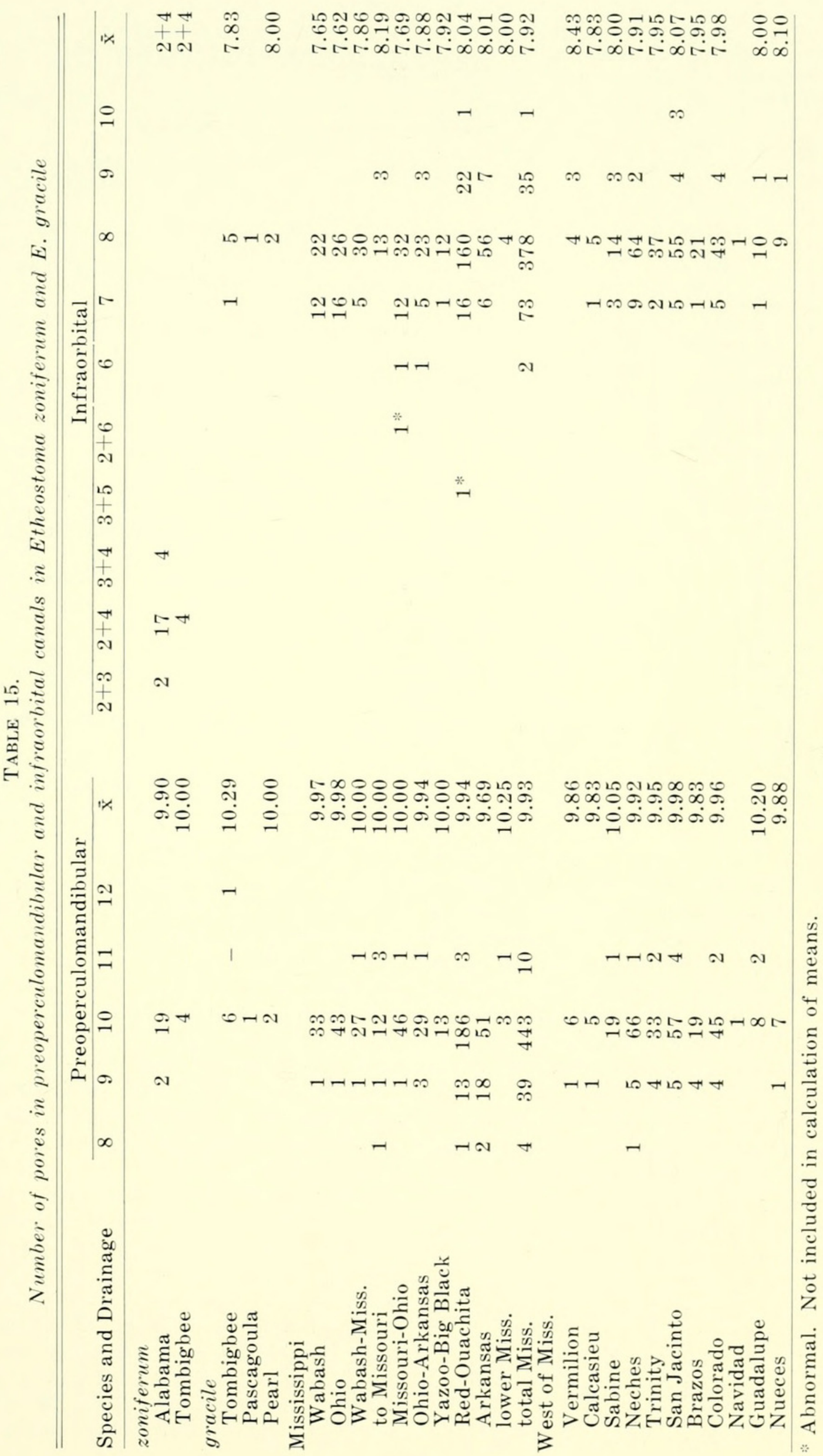




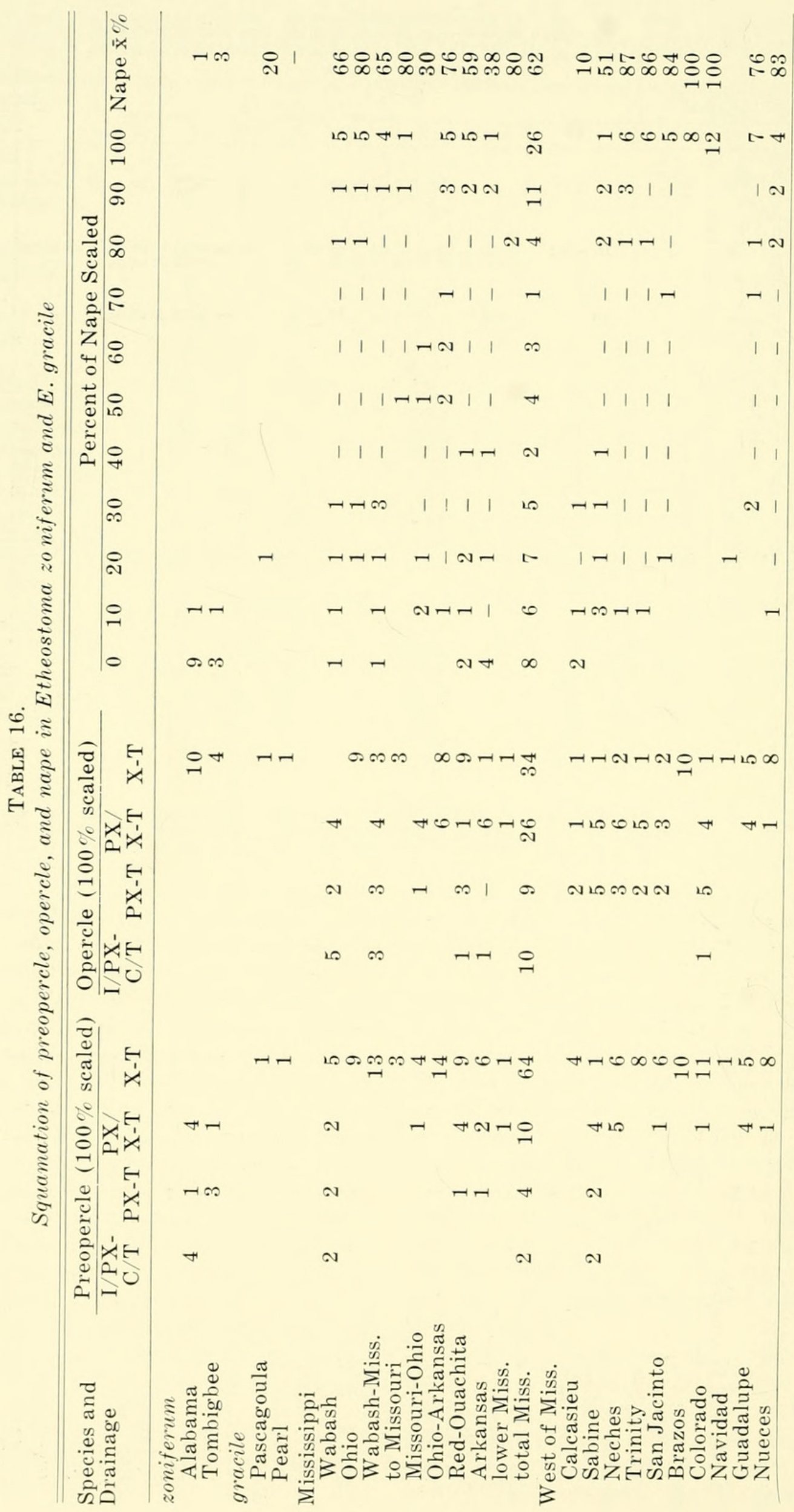


TABLE 17.

Habitat data for Etheostoma gracile collections from Texas

\begin{tabular}{|c|c|c|}
\hline Water Current & $\begin{array}{l}\text { Number of } \\
\text { collections }\end{array}$ & $\begin{array}{l}\text { Percent of } \\
\text { collections }\end{array}$ \\
\hline none & 8 & 19.0 \\
\hline slow & 8 & 19.0 \\
\hline none to moderate & 6 & 14.3 \\
\hline slow to moderate & 5 & 11.8 \\
\hline moderate & 4 & 9.5 \\
\hline none to fast & 2 & 4.8 \\
\hline slow to fast & 4 & 9.5 \\
\hline moderate to fast & 2 & 4.8 \\
\hline fast & 3 & 7.1 \\
\hline total & $\overline{42}$ & $\overline{99.8}$ \\
\hline Water Current & $\begin{array}{l}\text { Present in } \\
\text { collections }\end{array}$ & $\begin{array}{c}\text { Present in percent } \\
\text { of collections }\end{array}$ \\
\hline none & 16 & 38.1 \\
\hline slow & 25 & 59.4 \\
\hline moderate & 23 & 54.7 \\
\hline fast & 11 & 26.2 \\
\hline Aquatic Vegetation & $\begin{array}{l}\text { Number of } \\
\text { collections }\end{array}$ & $\begin{array}{l}\text { Percent of } \\
\text { collections }\end{array}$ \\
\hline none & 22 & 46.8 \\
\hline slight to moderate & 21 & 44.6 \\
\hline abundant & 4 & 8.5 \\
\hline total & 47 & $\overline{99.9}$ \\
\hline Bottom Type & $\begin{array}{l}\text { Present in } \\
\text { collections }\end{array}$ & $\begin{array}{l}\text { Present in percent } \\
\text { of collections }\end{array}$ \\
\hline mud and/or silt & 33 & 76.7 \\
\hline sand & 22 & 51.1 \\
\hline detritus & 14 & 32.6 \\
\hline gravel & 10 & 23.0 \\
\hline clay & 7 & 16.3 \\
\hline bedrock & 5 & 11.6 \\
\hline
\end{tabular}

ferred sluggish water and a mud bottom and Bridges (1958) recorded it from two farm ponds. The information presented by Forbes $(1907,1909,1914)$ and Forbes and Richardson (1909, 1920) is not reliable since they confounded Etheostoma exile, a species of cooler, cleaner waters, with $E$. gracile. However, both species prefer water with little or no flow. Forbes and Richardson (1920) found $78 \%$ of gracile-exile collections in areas of sluggish flow and Forbes (1907:303) and Forbes and Richardson (1920) reported that $66 \%$ of gracile-exile collections were made over muddy bottom. Forbes and Richardson, apparently mistakenly, reported this in their ecological table as $67 \%$ over rock and sand. Hancock and Sublette (1958) reported it from a sluggish brown-water bayou in Louisiana. Blair (1959) noted that E. gracile and E. chlorosomum are fishes of sluggish, muddy, streams and lakes in northeastern Oklahoma.
Species Associates-Forbes (1907) found a large coefficient of association between Etheostoma chlorosomum and E. gracileexile in Illinois. However, his figures are not accurate, because he confounded $E$. gracile with exile. If the northern collections of the allopatric exile could be eliminated the coefficient would be still higher. Etheostoma chlorosomum was taken in 6 out of 41 localities in the Poteau River of Oklahoma and Arkansas (Cross and Moore, 1952). At five of these localities, E. gracile was also taken. This association was also noted in several of my southern Illinois and Indiana collections. Fishes that are associated with $E$. gracile prefer or tolerate low gradient and/or silty bottoms and turbid water.

Habits-Forbes (1878) and Forbes and Richardson (1920) reported the food of a few Illinois specimens to consist of "larvae 
of gnats and of may-flies, with a few copepoda."

Forbes and Richardson reported that females taken in Illinois on April 28 contained "full-sized eggs." Hubbs and Cannon (1935) reported the breeding season in Illinois to be late March and April. Moore and Poole (1948) noted that specimens in an Oklahoma collection of E. gracile were "in breeding color" on April 19. Breeding tubercles are present in Texas specimens of E. gracile from February 19 to April 19 with their greatest development in midMarch. Therefore, the spawning season in Texas appears to be about mid-March.

The breeding behavior of E, gracile and zoniferum may differ slightly from that of E. fusiforme because these two species possess accessory breeding tubercles on the lower jaw rami. Perhaps the male rubs his chin along the nape of the female during courtship. The red in the first dorsal fin of male E. gracile and zoniferum indicates the presence of territoriality. My aquarium observations of $E$. gracile have indicated this with a dominant male occupying the corner of an aquarium where they were fed. This dominance was indicated by brighter colors and by chasing intruders. Also, pairs of male gracile have been observed spreading their dorsal fins at each other in an apparent threat posture. No specimens of E. fusiforme or E. serriferum have been seen to do this.

E. gracile does well in aquaria, specimens having been kept for several months on a diet of white worms, pieces of earthworms, frozen brine shrimp, and moistened pellets of dry food. Linder (1955a) also reported success in maintaining $E$. gracile in aquaria.

Distribution - Found along the Gulf Coastal Plain from the Tombigbee River in Mississippi west to the Nueces River of Texas and northward in the low lying areas of the former Mississippi Embayment (Fig. 5). Hubbs (1957b:98) reported E. gracile as occupying the Texan, Austroriparian, and Tamulipan biotic provinces of Texas, but absent from the Rio Grande drainage of the Tamulipan. In northeastern Oklahoma, Blair (1959) noted that E. gracile is found mostly in the sluggish, turbid streams of the Cherokee Prairie biotic province avoiding the clear, faster flowing streams of the Ozark biotic province. In Indiana it is known only from the lowland southwestern corner south of the Wisconsin glaciation (Gerking, 1945:95, map 94).

There is only one collection of E. gracile available from the Tombigbee River (UMMZ 113453, Lowndes Co., Miss.). E. zoniferum has been taken several times farther south in this river. These two are very similar to each other, so much so that I think they would probably hybridize if they came together. E. zoniferum is clearly an offshoot of $E$. gracile, and so they would not be expected to be in the same river system together. Therefore, there is a possibility that a stream capture allowed $E$. gracile to invade the upper part of the Tombigbee River. Tributaries of three different rivers approach this section of the Tombigbee; the Yalobusha, tributary to the Yazoo, the Big Black, and the Pearl. The tributary of the Big Black is the one that approaches closest to the Lowndes County locality and also there are more collections of E. gracile from it than from the other two rivers.

A better understanding of factors important in the distribution of $E$. gracile can be obtained by study of a limited area. Illinois was selected because Forbes and Richardson (1920) gave a lengthy account of the topography of the state, and because it has been well covered by collectors (INHS, UMMZ, CU). All known Illinois localities for $E$. gracile were plotted upon a map of glacial geology taken from Forbes and Richardson (1920, Map III). The collections they reported as Boleichthys fusiformis from the Rock River district of northeast Illinois refer to the superficially similar Etheostoma exile, as pointed out by Hubbs and Cannon (1935). The distribution of E. gracile in Illinois is listed below: (names from Forbes and Richardson, 1920: Atlas):

Drainage system

No. collections

Galena District, Rock River System, Lake Michigan Drainage, Mississippi Drainage none

Illinois River System _ 2

Kaskaskia River System 10

Wabash River System 20

Big Muddy River System _ 10

Saline River System $\quad 10$

Cairo District

Only two collections of E. gracile are from the Illinois River, which drains about three- 


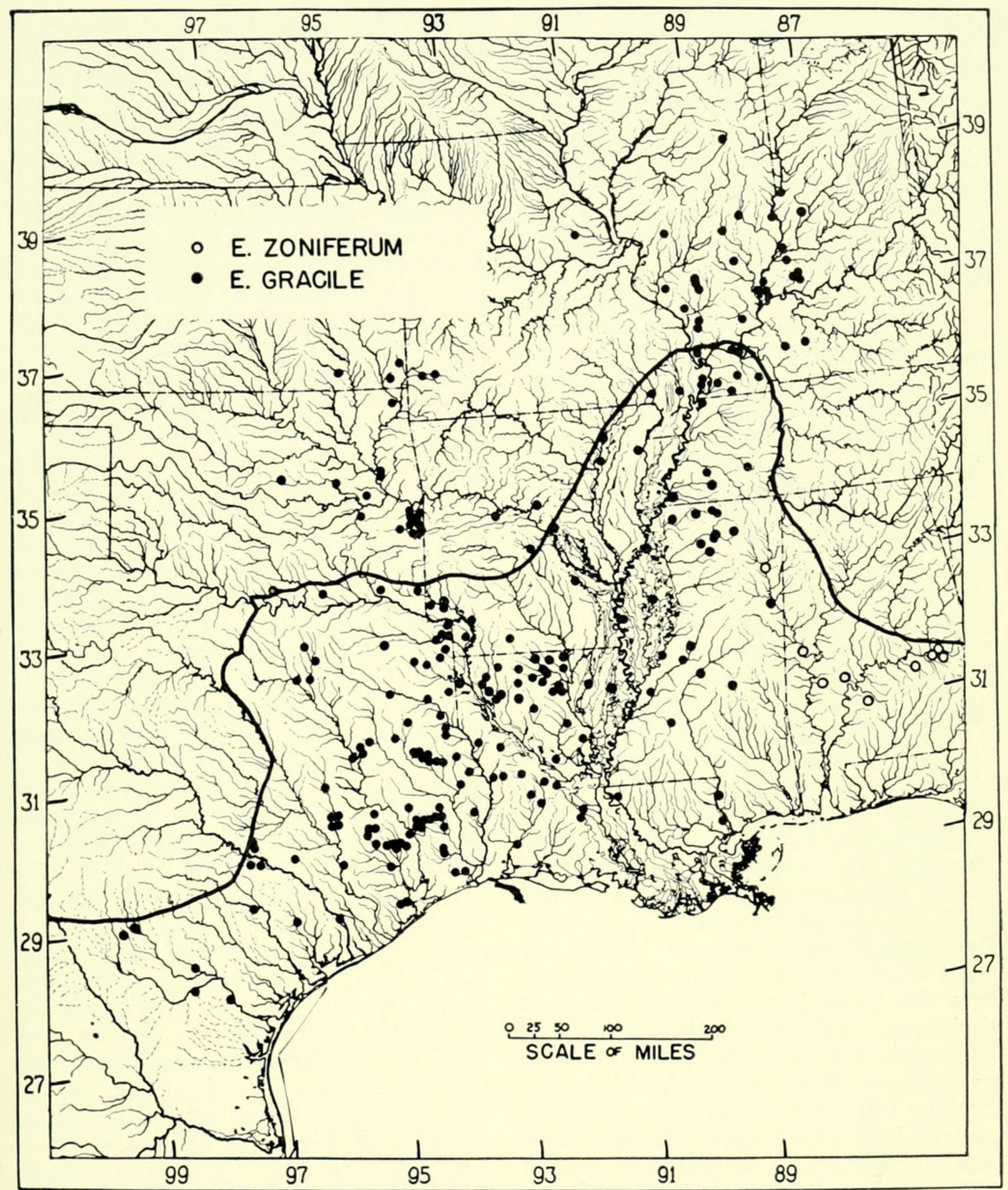

Figure 5. The distribution of Etheostoma gracile and E. zoniferum in relation to the Fall Line. (Based upon specimens examined)

sevenths of the state. This seems odd because the whole state has been covered thoroughly by collectors. Each collection is represented by only a single specimen. I have verified the identification of the Champaign Co. specimen and although the Christian Co. specimen appears to be lost (P. W.
Smith, personal communication), it was examined by Hubbs and Cannon so its actual identification is not suspect. The Champaign Co. specimen was mentioned in Thompson's field notes but no specimens have been taken in more recent collections (P. W. Smith, personal communication); 
therefore there is a possibility that the locality for the Christian Co. specimen is erroneous.

With the exception of the two abovementioned specimens and a specimen from a Madison Co. tributary of the Kaskaskia River, the remainder of the $E$. gracile collections are from only three of the nine physiographic areas of Illinois (Forbes and Richardson, 1920, Map III) :

1) Unglaciated areas (of southern Illinois only)

2) Lower Illinoisan Glaciation

3 ) Bottom lands (of Lower Illinoisan Glaciation only)

No. collections

The two Illinois River specimens came from the Wisconsin and Middle Illinoisan Glaciation area and the Madison Co. specimen came from the Middle Illinoisan Glaciation. Concerning the drainage of Illinois, Forbes (1909:381) pointed out that "...the headwaters and tributaries of its various stream systems so approach and intermingle that in times of flood they formed an interlacing network, through which it would seem that a wandering fish might have found its way in almost any direction and to almost any place." Why then is E. gracile so clearly limited to the southern part of the state? The answer lies in the glacial geology which, as Forbes (1909) pointed out, is more diversified than the topography. The Kaskaskia and Embarrass Rivers cut across the Shelbyville moraine which separates the lower Illinoisan and Wisconsin glaciations, but the distribution of $E$. gracile stops south of the moraine, although the bottomlands which are its preferred habitat continue across the moraine into the Wisconsin Glaciation for a short distance. Two physical factors seem important in limiting E. gracile distribution: current and turbidity.

Forbes (1909) presented a list of seven species tolerant of muddy bottoms and a list of thirteen species that avoid muddy bottoms. All the species in the former group are freely distributed over the lower Illinoisan Glaciation and all the species in the latter group avoid this area. The streams of the Wisconsin Glaciation are narrow and fast flowing, quickly carrying off any silt load they acquire. Forbes and Richardson
(1920) also pointed out that the soil of the lower Illinoisan Glaciation is an extremely fine-grained, light-colored clay which when washed into streams remains in suspension and renders the waters turbid for a long time. The correlation of turbid waters and muddy bottoms with $E$. gracile distribution seems to be due not to a preference of gracile for this type of habitat but to the fact that more species of fishes are present in the favorable upland habitat and have become specialized for certain ecological niches. They are therefore able to compete more successfully which leaves the muddy swamps by default to gracile and other fishes tolerant of poor conditions.

I have computed the gradient in feet per mile for streams in which $E$. gracile was collected, basing my calculations on the data of Forbes and Richardson (1920) and Luce (1933). In ten streams, the most upstream collection of gracile was found in areas having gradients of 1.0 to 6.7 feet per mile $(\mathrm{x}: 2.9 \mathrm{ft} / \mathrm{mi})$. The gradients that gracile avoids in these streams range up to $100 \mathrm{ft} /$ mi ( $\bar{x}: 18.3)$. Of course, most gracile were collected in backwaters and so were found at gradients of much less than $2.9 \mathrm{ft} / \mathrm{mi}$. It seems that the upstream spread of gracile is limited by fast water in the same way that the Atlantic Coast species of the subgenus Hololepis are limited by the Fall Line.

In Illinois and Indiana a number of species have distributions similar to that of $E$. gracile. Gunning and Lewis (1955) noted that Lepomis symmetricus, Elassoma zonatum, Chologaster agassizi, Gambusia a. affinis, and Centrarchus macropterus have their northern limit in southern Illinois. Four species are limited to the extreme southwestern tip of Indiana, in the area of the Wabash River and Ohio River flood plain (Gerking, 1945): Gambusia a. affinis, Centrarchus macropterus, and Etheostoma chlorosomum, in addition to Etheostoma gracile. Of twenty species of darters for which Gerking (1945) presented distribution maps, only E. gracile and E. chlorosomum are limited to the southwest corner of the state. Opsopoeodus emiliae also has the center of its Indiana distribution in the muddy waters of the southwestern corner of the state.

Geographic Variation-Tables 10-16 give frequency distributions of the characters 
examined and include E. zoniferum; this facilitates comparison between these closely related species. Several characters which showed little or no geographic variation are given only in the species comparisons tables (Tables 38-49); squamation of interorbital, parietal, and breast (naked); condition of preopercle (entire); coronal pore (present); interorbital pores (usually absent, rarely $1-2$ ); pectoral rays (mode usually 13, a few populations with 12); branchiostegals (usually 6, Mississippi to Missouri population with a mode of 5 ).

The number of pored and total lateralline scales showed little difference between populations (Tables 10-11). The modal number of dorsal spines was nine in all populations except for an Audrain Co., Mo. collection (UMMZ 149331) which had a mode of ten (Table 12). The modal number of second dorsal rays is 11 in all populations except Missouri to Ohio and Colorado, which have 12 (Table 12). A spine was present in the anterior part of the second dorsal fin more often in E. gracile (13 specimens) than in the other species of the subgenus Hololepis. Most specimens of $E$. gracile had two anal spines but 22 specimens had only one spine and one specimen had three (Table 42). The modal number for anal rays was either six or seven (Table 13).

By use of the number of scale rows above the lateral line (Table 14), populations of gracile may be divided into three groups: Populations east of the Mississippi with a low number (mode of three); the Mississippi, Vermilion, and Calcasieu populations with a moderate number (modes three or four); and a western group from the Sabine through the Nueces, with means greater than 3.75 (except for the Brazos) and a mode of four. In regard to the number of scale rows below the lateral line (Table 14) the Nueces population stands out with a mean of 9.73. The other populations had means from 8.5 to 9.0 , with the exception of the Trinity population, which was intermediate with a mean of 9.46 .

There were no important differences between populations in the number of head pores. Most specimens had ten preoperculomandibular pores but some individuals had as few as eight or as many as 11 (Table 15). Two anomalous specimens had incomplete
POM canals (Missouri-Ohio and Neches systems). Both had counts of $5+6$, and therefore would have had normal counts of ten if the canal had been complete. The infraorbital pores are typically eight (Table 15) but range from six to ten. The INF canal is typically complete but two individuals had $3+5$ (Red River) and $2+6$ (Missouri-Ohio drainage). Both of these would be low counts of seven if the canals were complete. The supratemporal canal is usually complete in adults but in most collections a few specimens had incomplete canals (see development).

The preopercle (POP) and opercle (OP) are completely covered with scales but the character of squamation varies (Table 16). Most specimens had POP covered with exposed ctenoid scales (X-T) but a few had the squamation less well developed. One Sabine River specimen had imbedded cycloid scales and the sample had a mode of $\mathrm{PX} / \mathrm{X}-\mathrm{T}$. The OP squamation was similar but less well developed. The mode is usually $\mathrm{X}-\mathrm{T}$ but it varied to $\mathrm{I} / \mathrm{PX}-\mathrm{T}$ in the Wabash population. The extent of the nape that was covered by scales varied from 0$100 \%$ within many populations, but the mode was usually $100 \mathrm{I} / \mathrm{PX}-\mathrm{T}$ (Table 16).

The most interesting result of comparison of populations of E. gracile is that although there is a large amount of variation within systems and within collections as in E. fusiforme, there is much less difference between populations. This is probably due to less complete isolation, than in fishes living along the Atlantic Coastal Plain.

Specimens Examined-Specimens examined are given by drainage system, state, county, and museum number, except for localities at the margins of the range and type localities of nominal species. A total of 1580 specimens from 309 collections was examined. Complete data for most of the collections are listed in Collette (1960).

Tombigbee Dr., Miss.-Lowndes Co.: UMM7 113453 (10, 28-36) ; Tombigbee R., $3 \mathrm{mi}$. W of Columbus : Aug. 18, 1931

Pascagoula Dr., Miss.-Newton Co. CU 3379 . (1. 33 ) : trib. of Leaf $R$. between Lawrence and Lake on US so: Oct. 25, 1958.

Pearl Dr., Miss.-Pearl River Co.: TU 14423 $(1,30)$; oxbow of W. Pearl R., 3.2 mi. E of Bogalusa, La. : Nov. 11, 1956. Rankin Co. USNM $129113(25,13-21)$; borrow pits on Meeks Ferry Rd. along Pearl R. : June 12, 1933. La.St. Tammany Par.: UMMZ $163687^{-}(1,40)$; ditch 1 mi. E of Pearl R. village; Apr. 15, -1951.

Mississippi River

Ohio-Wabash Dr., 40 specimens. Ind.-Gibson Co. : UMMZ 81382." Green Co.: USNM 34983 (1. $31)$; Switz City Swamp; Aug. 1883; lectotype of 
Poecilichthys palustris. Knox Co. : UI 425. Posey Co.: UI 446. I1l.-Ciawford Co.: INHS uncat. Cumberland Co.: CU 34586. Effingham Co. : UMMZ 105940 . Wayne Co.

Co.: CU 32245 ; $T$ T 19326.
Ohio Dr., 44 specimens, Ind.-Warrick Co. UMMZ 81406; UI 440, 441; CU 32246. Ку.Muhlenberg Co. : ( U 22186.

Wabash to Mississippi Dr., 38 specimens, Ill.Massac Co.: INHS 4 uncat. coll. : TU 35155. Saline Co.: INH's uncat. Ky.-Hopkins Co. USNM 63782. Marshall Co. : UMMZ 168360.

Middle Mississippi

To Missouri Dr. 17 specimens, Ill.-Champaign Co. INHS uncat Mo-Audrain Co: DMM 149331 .

Missouri to Ohio Dr., 63 specimen, Ill.-Alexander Co.: UMMZ 111594. Bond Co.: CU 34587. Jackson Co.: UMMZ 107048, 105930. Jefferson Co. : UMMZ 105866, 16s066. Mandolph Co. 131198. Perry Co.: UMMZ 130301. Randolph Co. UMMZ 163079 . Union

Ohio-Arkansas Dr., 45 specimens, Ark.-Craighead Co.: USNM 125086. Ky.-Graves Co.: USNM 63783: TU 3018. Hickman Co.: UMMZ 15781 Miss, Coahoma Co.: USNM 129185. 154781. Miss.-Coahoma Co.: Mississippi Co. Mo.-Butler Co. : UMMZ 139647. Mississippi Co. Co. CMMZ 153159. Tenn.-Chester Co. : UMMZ 168526. Haywood Co. : UMMZ 161034. Obion Co. UMMZ 105396; CU 33346. Shelby Co.: USNM 195973 .

Lower Mississippi

Yazoo-Big Black Dr., 35 specimens, Miss. Benton Co.: UMMZ 161444, 162897; UM H51-2, Copiah Co. UMMZ 170715, De Soto Co. : USNM 129013, 129593. Hinds Co.: UMMZ 170744. Holmes Co.: UMMZ 161108. Lafayette Co. : UMMZ 161392, $162923 ; 161054$. UM $51-2,55-16$. Marshall Co.: OMMZ 161054, Union Co. Sunflower Co.: Warren Co.: USNM 129110. UMMZ 144722. Warren Co. USNM 129110. USNM $32224(1,44)$; Vaughan's Station, pool along Big Black R., Aug. 20, 1881 ; holotype of Poecilichthys butlerianus; USNM 129140.

Arkansas Dr., 169 specimens, Mo.-Barton Co. UMMZ 151793, 151815. Ark.-Arkansas Co. TU 2196. Faulkner Co. : Univ. Ark. uncat. coll. Jackson Co.: UMMZ 123620. Lawrence Co. USNM 109881. Pulaski Co.: UMMZ 123262. Yel Co.: TU 24466. Okla.Craig Co. $\begin{array}{lll}\text { OAM } & 5172 .\end{array}$ Le Flore Co.: UMMZ 109427; OAM 972, 1001 , $1136,1234,1090,782,1182,1319,1343,1357$, 1403, 1390, 4473. Lincoln Co. : OAM 4529. Mc4329, 5054. Okmulgee Co. : UMMZ 107052. Osage 4329, OAM uncat Ottawa Co.: OAM 5147. Pittsburg Co.: OAM 4961. Kans.-Cherokee Co. : UMMZ $144463(2,29-30)$; Fly Cr., 4 mi. S and $3 \mathrm{mi}$ IV of Hoover at Columbus; July 26, 1946. Craw ford Co.: UK $2255(6,29-36)$; Clear Cr. and Second Cow Cr., Sec. 20, T29S, R24E; Apr. 18 , 1952. UK 2933 (4, 31-34); Cow Cr., Sec. 20 T29S, R24E; Apr. 10, 1953 . Montgomery Co. T29S, R24E; Apr. 10, 1953 . Montgomery Co. pendence and Elk City on US 160; Mar. 28, 1961 Red-Ouachita Dr., 717 specimens, Ark.-Colum bia Co.: USNM 165848. Hempstead Co.: UMMZ 123169. Howard Co.: TU 10165. Lincoln Co. UMMZ 127832. Little River Co. : UMMZ 170868 Miller Co.: UMMZ 123135, 123125. Saline Co. : S6470. Sevier Co.: TU 10165.172878 Bienville Par.: UMMZ 170842; USNM 172608, Bossier Par. 17.6002 , Caddo Par.: CU 32249 172661, 172883, 173002. Caddo Par. : CU 14372 . Catahoula Par. TU 4343. Claibourne Par. : UMMZ 161294. Grant Par, TU 907, 2096, 4296. Jackson and Bienville par. : USNM 172576. Lincoln Par. : UMMZ 161310 ; USNM 172495, 172623, 172523, 172745, 161310 ; 172934 . Madison Par.: USNM 172732 . 172889, 172934. Madison Par.: OU. Ouchita Par. : UMMZ 170780, 170804; USNM 172762. St. Landry Par.: TU 961, 1021. Union Par.: TU 14355 USNM 172481, 172560, 172570, 172677, 172692, $172709,172812,172833,172861,172911,172953$. 172709, 172812, 172833 , 'USNM 172648, 172988. Webster Par.: TU 1355 ; UNM 172648,172988 . Okla.-Bryan Co.: OAM 4192. Choctaw Co.: OAM UK 2418 ; OAM $2165,3074,3004,5169$; CU
17890, 33746. Tex.-Bowie Co.: OAM uncat. ; TNHC 3529, 3930, 4992. Bowie and Cass cos. TNHC 3179. Cass Co. : TNHC 3508, 3542, 3952 4044, 4092. Franklin Co.: TU 14070. Harrison Co.: TNHC 2048. Morris Co. : TNHC 3845 . Red River Co.: TNHC 4994.

Calcasieu Dr. 6 specimens: La.-Allen Par. Calcasieu Dr., 6 specimens 172116 ; TU 14050 . Calcasieu Par. ANSP 55538. Vernon Par.: UMMZ 170594; TU 14090.

Sabine Dr., 34 specimens; La.-Sabine Par. TU 976, 4564. Vernon Par.: TU 14360. Tex.Harrison-Panola cos. : TNHC 3217. Newton Co. TNHC 3300. Panola Co: CU 34909. Sabine Co. TNHC 465. Shelby Co. : TNHC 3387. ShelbyTNHC 465. Shelby Co. : TNHC 3387. Shelby-

UMMZ 170038.

Neches Dr., 129 specimens, Tex.-Cherokee Co. TNHC 3809. Hardin Co.: TNHC 488, 578; TU $21651,22214,21417$. Nacogdoches Co. : UMMZ 170469 ; TNHC 363, 371, 202. 400, 1061, 1231 , 1776,556 ; TU 14037. Polk Co. : UMMZ 170446 TNHC 2419, 2575, 2696. Rusk Co. : CU 34590 Sabine Co.: UMMZ 170502. San AugustineNacogdoches cos.: UMMZ 170480. Tyler Co. TNHC 2943; TU 14085, 21373, 21464, 21718 , TNHC

Sabine Lake Dr. (Neches plus Sabine), 4 specimens, Tex. - Jefferson Co.: TNHC 4181; TU

Trinity Dr., 44 specimens, Tex.-Anderson Co.: TU 3801 Collin Co: TNHC 3434, 3739. Freestone Co. : CU 33819. Kaufman Co.: TNHC 4008. Madison-Walker cos. : TU 4899. Polk Co. : TNHC $509,1345,1601,2029,2720,2757$. San Jacinto Co. UMMZ 170429

San Jacinto-Galveston Bay Dr., 68 specimens, Tex.-Harris Co.: UMMZ 86325, $170399,158845$. Liberty Co. : TNHC 1587. Montgomery Co. : UMMZ 147541: TNHC 1165, 1394, 1146, 1204, $1219,1476,1517,2004,2957$; TU 14065. Walker Co, TNHC $1006,1793,2750$.

Brazos Dr., 23 specimens, Tex.-Brazos Co.: UMMZ 129938, 129863, 129804, 129749. Robertson Co. : CU 33333. Waller Co.: TNHC 4267. Colorado Dr., 52 specimens, Tex.-Bastrop Co. : 2541 . Wharton Co.: UMMZ 170310

Vavidad Dr. Tex.-Lavaca Co. TNHC 1264 Navidad Dr., Tex.-Lavaca Co. S TNHC 1264
$(1,40)$; Navidad R., 2 mi. NW Seclusion; May 5,1951

Guadalupe Dr., Tex.-Gonzales Co.: USNM 166171 (16, 22-41) ; Guadalupe R., L. Belmont, 2 mi. above Wrights Camp ; Apr. 17, 1952.

Nueces Dr., Tex.-Live Oak Co.: Lake Corpus Christi State Park. TNHC 4975 (1, 37); Feb. 1954 and TNHC $4974(1,41)$; Dec. 11, 1956. McMullen Co.: TNHC 1766 (6, 34-38); Nueces R 10 mi. IV Sutton: Dec, 6, 1947. TNHC 3005 (i, 38) : 8.6 mi. N Tilden, San Miguel Cr. ; Jan. 15,1952 . Uvalde Co.: USNM $1328(1,36)$; lectotype and MCZ $113(1,36)$; paratype; Rio Seco near Ft. Inge; and USNM 1329 (1, 31); Leona R. near F. Inge; paratype of Boleosoma gracile.

\section{Etheostoma zoniferum (Hubbs and Cannon)}

Hololepis zonifer-Hubbs and Cannon, 1935; 47-50, pl. I-III (original description); Fowler, 1945: 40 (Ala. R. after Hubbs and Cannon).

Etheostoma zoniferum-Bailey and Gosline, 1955:20, 44 (number of vertebrae); Eddy, 1947:219; Moore, 1957:198; Cook, 1959:35, 200, 208 (Miss.); Collette, 1961: 2051.

Types-Holotype, UMMZ 88803, $31 \mathrm{~mm}$ female; Ala., Pools of Catoma Cr., $5 \mathrm{mi}$. SW of Montgomery; Sept. 18, 1929; Creaser and Becker. Paratype, UMMZ 88822; Ala., Lowndes Co.; Pools of Big Swamp Cr., 25 
mi. SW of Montgomery; Sept. 18, 1929; Creaser and Becker.

Diagnosis-E. zoniferum differs from its close relative $E$. gracile primarily in having the infraorbital canal incomplete with $2+4$ pores. It also has fewer anal rays (mode: 6, $\bar{x}: 5.9$ ), fewer scale rows above the lateral line (mode: $3, \overline{\mathrm{x}}: 3.2$ ) and below the lateral line (mode: $8, \overline{\mathrm{x}}: 8.2$ ). Maximum size of males - $36.6 \mathrm{~mm}$ and females $35.0 \mathrm{~mm}$ (Tombigbee R., UMMZ 163758).

Coloration-No specimens of non-breeding adult males or females were available. The patterns of breeding E. zoniferum are like those of breeding E. gracile; the patterns of the non-breeding individuals are probably also similar. The pattern of the non-breeding female zoniferum is probably like that of the breeding female zoniferum, as is usual in the subgenus Hololepis.

There are a few scattered medium-sized melanophores on the first dorsal fin membranes in the breeding female. Small melanophores are concentrated on the distal portions of the posterior membranes. The second dorsal rays are barred and large melanophores are scattered on the membranes, especially on the basal eighth of the fin. Melanophores outline the anal rays, and a few are present on the posterior membranes. The pectoral rays also are outlined. The pelvic fin is clear. The caudal fin is barred. The breast and belly are immaculate, with a few melanophores sometimes present posteriorly on the belly. Large melanophores are scattered on the cheek. All four orbital bars are present; the suborbital is the most prominent; the supraorbital extends onto the eye. The pored portion of the lateral line stands out as a narrow light line, but pigment is sometimes present on the distal margin of the pored scales. The median basi-caudal spot is prominent and indistinct spots are present at the upper and lower bases of the caudal fin. The sides are brown with blotches more or less apparent. The dorsal saddles are indistinct. The genital papilla is unpigmented. Figure 4 compares the patterns of breeding females of E. zoniferum and gracile.

The pectoral and caudal fins, basi-caudal spots, dorsal body surface, and genital papilla in the breeding male are colored like the respective parts of breeding females; other areas are darker. Melanophores are concentrated in the lower two-thirds of the first dorsal fin except for a narrow light basal area. The barring of the rays of the second dorsal fin is somewhat obscured by the greatly increased number of melanophores on the membranes. The anal and pelvic fins and the belly and breast are uniformly covered with small melanophores. The suborbital bar appears less distinct in the male because the cheek is darker. There is more pigment on the posterior portions of the pored lateral-line scales than in the female. The sides are more uniformly brown. The patterns of breeding males of E. zoniferum and gracile are compared in Figure 4.

In life, E. zoniferum is quite colorful. R. M. Bailey's field notes on UMMZ 158228 described the male as having a sub-terminal orange band on the first dorsal. The top of the head was a greenish-olive. The lower fins were white. The back was creamcolored and barred with brownish-grey. The lateral bands were greyish-blue.

Carl L. Hubbs' field notes on UMMZ 163758 described the male as having red spots forming a series along the light streak in the first dorsal fin. The red was rather indistinct forward and stronger posteriorly, and the spots were smaller posteriorly. There was a trace of these marks in the female. The first dorsal fin of the male was sooty. The body of the male had deep metallic blue-green lateral bars. The color has completely faded out in the preserved specimens.

Genital Papilla.-The genital papilla in the breeding female is like that of E. gracile (Fig. 1c).

Breeding Tubercles-Tubercles are present on the anal fin rays and on the rami of the lower jaw. None have been seen on the pelvic fin rays, probably because of lack of material taken at the height of the breeding season. A few small tubercles are present on the distal parts of the anal fin rays, especially on the distal third of the third ray. In a $38 \mathrm{~mm}$ male taken on April 16 (UMMZ 163758) from the Tombigbee River, there are four low tubercles in a row on the ramus of the right half of the lower jaw but none are discernible on the left half. This incomplete development of the jaw tubercles is taken as further evidence that the tubercles of this specimen either 
have not reached, or are past, maximum development. The distribution of tubercles on the chin and anal fin is like that in $E$. gracile (Fig. 1h, m).

Development-There is little information on the change of characters with age in $E$. zoniferum. The supratemporal canal seems to show the same changes as in E. fusiforme. Eight specimens smaller than $25.9 \mathrm{~mm}$ had incomplete supratemporal canals, sixteen between 26.0 and $29.9 \mathrm{~mm}$ were equally divided between complete and incomplete, and the five available specimens $30.0 \mathrm{~mm}$ and larger had complete canals. None of the available specimens were small enough to detect any other changes with age.

Habitat-Hubbs and Cannon (1935) described the habitat at the first two !ocalities from which the species was known as pools in creek bed; water: clear, murky; bottom: gravel, mud; depth to four feet; vegetation: sparse Chara; temperature: moderate, warm.

Distribution-Found only in the Alabama and Tombigbee Rivers below the Fall Line (Fig. 5). I do not know why it is not distributed still farther south in these two river systems. Both E. gracile and zoniferum have been taken in the Tombigbee River in the state of Mississippi. Further collecting is desired in order to find out if they occur together.

Geographic Variation-Tables 10-16 compare the Alabama and Tombigbee populations of E. zoniferum with the populations of E. gracile. On the basis of the small samples now available, there seem to be no differences between the populations of the two rivers. Tables 38-49 compare E. zoniferum with the other species of the subgenus Hololepis.

\footnotetext{
Specimens Examined-Alabama R., Ala.-Macon Co. : UMMZ $111223(2,22-23)$; $3 \mathrm{mi}$. E of Tuskegee; June 3, 1931. UMMZ 124012 (14,24-28) and USNM 117546 (1, 27); Slough Lake. Tuskegee, East Opintoloco Cr., Sept. 13, 1937. UMMZ $124020 \quad(2,30-34)$; Big Swamp, Tuskegee; Sept. 13,1937 . API $566(2,26)$ Slough Lake. SE of Tuskegee, Opintoloco Cr. Sept. 13, 1937. API $567(1,37)$ : Watering $\mathrm{Br}$. Tuskegee; Oct. 3, 1939 . Montgomery Co. : UMMZ $88803(1,30)$ : pools of Catoma Cr., $5 \mathrm{mi}$. SW of Montgomery ; Sept. 18, 1929; holotype of Hololepis zonifer. UMMZ 158228 (1, 27); cr. $19 \mathrm{mi}$ SE of Montgomery on US 231; Sept. 4, 1939 Wilcox Co.: UAIC 526 (1, 26); Chilatchee Cr. near Alberta: Aug. 30,1956 . UAIC $536(1,29)$ : Prairie Cr., $13 \mathrm{mi}$. E of Camden and $0.5 \mathrm{mi}$. W of Oak Hill near Ala. 10; Aug. 30, 1956.

Tombigbee R., Ala.-Marengo Co.: UAIC 428 $(1,28)$; Beaver Cr., $10 \mathrm{mi}$. SW of Linden (near Ala. 79 and $10 \mathrm{mi}$. N of jet with Ala. 10);

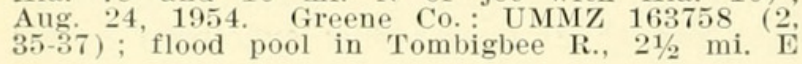

of Epes: April 16, 1941. Miss-Monroe Co.: UMMZ $157751 \quad(1,28)$; Tombigbee R., 21/2 $\mathrm{mi}$. W of Amory ; Aug. 16, 1939 .

\section{Etheostoma fusiforme fusiforme (Girard)}

Boleosoma fusiforme-Girard, 1854:41 (original description).

Hololepis fusiformis_Putnam, 1863:4 (original description of Hololepis by Agassiz); Cope, 1864:233 (diagnosis of the species of Hololepis); Greeley, 1939:43 (Long Island, N. Y.); Webster, 1942:127, 196, 203 (Pataganset Lake, Conn.); Cronk, 1950:d (Long Island); Everhart, 1950:43-44 (Me.); Raney, 1950:177-178, 186, 190 (James R., Va.); Smith, 1950: (fish fauna of N. J. lakes and ponds); Smith, 1953a: (N. J.); Smith, 1953b:168 (acidwater fishes of southern N. J.) ; Stroud, 1955:7, 353 (Ames Long Pd., Mass.); Fletcher, 1957:202-203 (N. J. specimens spawned in aquarium); Mullan and Tompkins, 1959:132.

Hololepis erochrous-Cope, 1864:232 (original description); Fowler, 1940:23 (Bucks Co., Pa.); Fowler, 1952:124 (locality records, N. J.).

Boleichthys fusiformis-Smith, 1907:267268 (in part, N. C.); Fowler, 1911:13 (ecology, Del.); Schrenkeisen, 1938:234 (brief description); Fowler, 1935:6 (in part, general distribution); Driver, 1942: 285 (in key, in part); Driver, 1950:298 (in key).

Copelandellus quiescens-Smith, 1907: 268-269 (in part, ecology and spawning, N. C. ).

Hololepis fusiformis erochrous-Hubbs and Cannon, 1935:72-77, pl. I, III (description, range, synonymy); Mansueti, 1951: 301-302 (ecology, Md.); Harmic, 1952:12 (Del.); Mansueti and Elser, 1953:118 (ecology, Chambers Lake, Md.); Truitt, 1953:1 (in Md. pond after rotenone application).

Hololepis fusiformis atraquae-Hubbs and and Cannon, 1935:68-72, pl. I, III (original description); Fowler, 1945:40 (Potomac R.) .

Hololepis fusiformis insulae-Hubbs and Cannon, 1935:83-86, pl. I, III (original description).

Hololepis fusiformis metae-gadi--Hubbs and Cannon, 1935:81-86, pl. I, III (original description). 
Hololepis fusiformis fusiformis-Hubbs and Cannon, 1935:77-81, pl. I, III (description, range, synonymy); Gordon, 1937:102, 116 (N. H.); Bailey, 1938:150-151, 156161, 176-177, 183 (Merrimack River watershed, N. H.); Bailey and Oliver, 1939:152, 179, fig. 78 (N. H.); Cooper, 1939:55 (Me.); Carpenter and Siegler, 1947:77 (N.H.) ; Harrington, 1947:191 (fry in N. H.).

Hololepis thermophilus-Hubbs and Cannon, 1935:63-67, pl. I, III (original description); Fowler, 1945:40 (Neuse R.); Frey, 1951:9, 37-41 (N. C. Bay Lakes).

Hololepis thermophilus thermophilusBailey and Frey, 1951:191-204, pl. 1-8 (comparison with $H$. thermophilus oligoporus).

Hololepis thermophilus oligoporus-Bailey and Frey, 1951:191-204, pl. 1-8 (original description).

Etheostoma fusiforme fusiforme-Bailey and Gosline, 1955:20, 44 (number of vertebrae); Collette, 1961:2051.

Etheostoma fusiforme erochroum-Bailey and Gosline, 1955:20, 44 (number of vertebrae).

Etheostoma fusiformis-Smith, 1957: (N. J.), 125-126 (food of Esox niger).

Etheostoma thermophilum-Moore, 1957: 198.

Etheostoma fusiforme-Eddy, 1957:219, 222, fig. 546; Moore, 1957:198; Collette, 1958:77 (ecology, Me.); Behnke and Wetzel, 1960:143 (Conn.).

Etheostoma barratti-Eddy, 1957:220 (range, in part); Knapp, 1953-128 (range, in part).

Types-Hubbs and Cannon (1935) selected USNM 1188, a $33 \mathrm{~mm}$ female, as the lectotype from a series of syntypes (USNM 94686 ) collected by S. F. Baird in a tributary of the Charles River at Framingham, Mass. Other paratypes of the same original lot are MCZ 24589 (4 specimens) and UMMZ 86582 (1 specimen).

Diagnosis-Distinguished from the other species of the subgenus Hololepis by a combination of the following characters: two anal spines; interorbital pores absent; usually nine preoperculomandibular pores; infraorbital canal incomplete; breast entirely scaled. Distinguished from E. f. barratti by the following: preopercle usually entire ( $90 \%$ of specimens examined); infraorbital usually $2+3(80 \%)$; fewer interorbital scales $(0-12, \overline{\mathrm{x}}: 2.0)$; parietal less completely scaled (usually $0-20 \%, \overline{\mathrm{x}}: 9.5 \%$ ). Maximum size of males $44.1 \mathrm{~mm}$, females $49.3 \mathrm{~mm}$ (CU 33194, N. Y., Suffolk Co., Lower Lake Yaphank).

Coloration-The patterns in this form are extremely variable. Much of this variation is associated with the color of the water from which the specimens were taken, darker stained waters generally produce darker fish, etc. The following description is based upon "typical" specimens and the most common variations from the "typical" pattern.

In the female small melanophores are concentrated on the posterior edge of the first dorsal spines and a few scattered melanophores may be present at the base of the membranes. Some large melanophores are scattered over the membranes of the second dorsal fin. The anal rays are barred; some specimens have a few melanophores on the membranes. The pelvic rays bear a few scattered melanophores. The pectoral and caudal fins are barred. The belly and breast vary from being immaculate to having scattered melanophores. The cheek has a few scattered large melanophores. All four orbital bars are present; the suborbital is usually the most prominent; the supraorbital extends onto the eye and the suborbital sometimes does so. The pored portion of the lateral line appears as a narrow light line which is interrupted by some pigment underneath the scales. There is usually a prominent black basi-caudal spot just below the center of the caudal base; the dorsal and ventral basi-caudal spots are usually faint. The sides have 8-13 indistinct dark brown or black blotches below the lateral line, which tend to fuse into a dark lateral band. Some specimens, especially from New Jersey and Delaware, have this lateral band exceptionally prominent in contrast to the upper part of the body which is a light tan. Approximately 12 dorsal saddles alternate with the lateral blotches in some specimens. The genital papilla is usually unpigmented, but small melanophores often encircle the anal region. Figure 6 compares breeding females from five localities.

In the non-breeding male the pectoral, pelvic, and caudal fins, orbital bars, basicaudal spots, genital papilla and dorsal body 

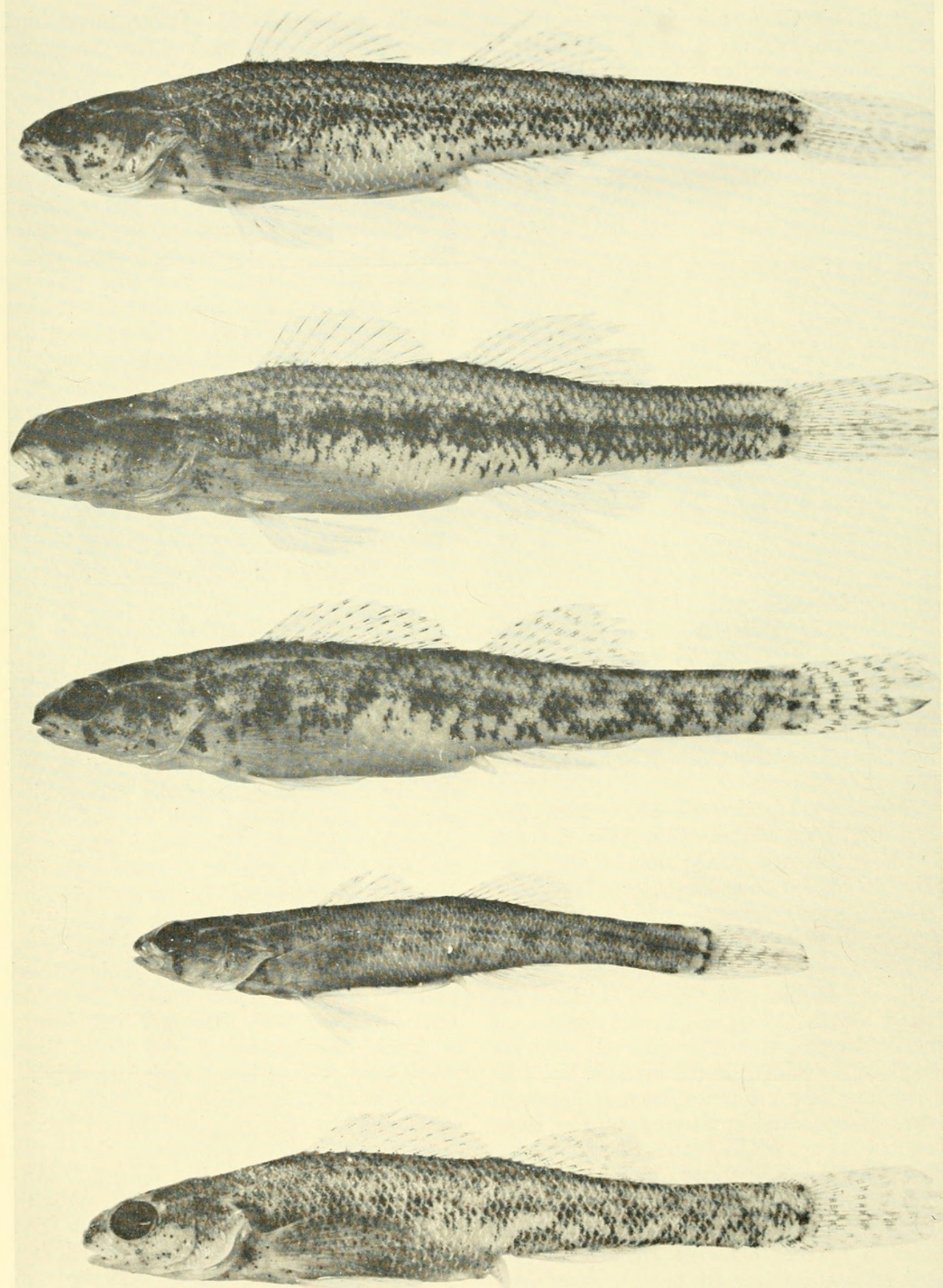

Figure 6. Breeding patterns of female Etheostoma fusiforme fusiforme. (from top to bottom) CU 31847; 38.5 mm; N.Y., Suffolk Co., Lake Yaphank; Apr. 19, 1958. CU 32725; $38.0 \mathrm{~mm}$; N.J., Atlantic Co., Great Egg Harbor dr.; May 16, 1959. CU 31640; 37.9 mm; N.C., Northampton Co., Roanoke dr.; Apr. 4, 1958. CU 25304; $28.4 \mathrm{~mm}$; N.C., Bladen Co., Jones Lake; Aug. 24-26, 1947. CU 14302; 35.7 mm; N.C., Columbus Co., Waccamaw dr.; Mar. 29, 1949. (Photograph by Douglass M. Payre) 
surface are colored like the female; the other areas are darker. The dorsal and anal fins have varying numbers of melanophores scattered on the membranes. The belly and breast range from immaculate to being covered with small melanophores. The cheek is darker than that of the female. The narrow light line is interrupted more than it is in the females. Most non-breeding males tend to have the body more uniformly pigmented, obscuring the lateral blotches.

In the breeding male the pectoral and caudal fins, pored portion of the lateral line, basi-caudal spots, genital papilla, and dorsal body surface all have the same melanophore distribution as the non-breeding male; other regions are darker. The large number of melanophores present on the dorsal fins coalesce, in specimens from some localities, and form a solid black band (Fig. 7). The pigmentation is most intense on the first three or four interspinous membranes. The anal and pelvic fins have large melanophores scattered over their membranes; these are usually more prominent on the anal. The cheek, belly, and breast are much darker than in the female and non-breeding male. The sides are similar to the non-breeding male, but with lateral blotches obscure in some specimens. Figure 7 shows the pigment pattern of breeding males from five localities.

Genital Papilla-In the breeding female, the genital papilla is an elongate tube with a slit opening on the anterior side (Fig. 1f). The papilla is a conical tube either with or without a bulbous enlargement similar to that usually present in E. gracile (Fig. 1h). The tip is more pointed than in the other species of the subgenus Hololepis.

Breeding Tubercles-Present on the anal rays (similar to $E$. gracile, Fig. $1 \mathrm{j}$ ) and on the undersides of the pelvic rays (Fig. $1 \mathrm{k}$ ). They seem to be less developed in E. fusiforme fusiforme than in E. f. barratti, and are present for a shorter time. Tubercles have been found on specimens from only fourteen collections and in some series, small tubercles were present on only one or two specimens. This may be because most collections were either made before or after the spawning season. In the southern part of the range, tubercles have been found on: March 25 (Ellis Lake, CU 29983); March 28 and 29 (Waccamaw R., DU B-49-12 and CU 14302); April 4 (Roanoke R., CU
31640); and March 27 (Chowan R., CU 16880). Tubercles have been found on specimens from a number of New Jersey collections made on May 17 and 18, 1958 and 1959 (CU 31083, 32739, 31797, 31787 , 31791, 31794, 32744). One specimen taken on March 27 in Lake Yaphank, N. Y., (CU 31850 ) had tubercles on the anal fin while most males in an April 19 collection (CU 31847) had tubercles on both anal and pelvic fins.

Development-Two characters clearly change with age in E. fusiforme fusiforme: the condition of the supratemporal canal and the number of pored lateral-line scales. The supratemporal canal is incomplete in young and juveniles and normally becomes complete by maturity. Table 31 shows the development of this character in a number of E. fusiforme populations. The Long Island population may be taken as an example of normal development. In young specimens the supratemporal canal extends only part way up the side of the head, with the two sides of the canal widely separated. The two sides grow toward each other until they join and the only vestige of the former separation is the central pore. All Long Island specimens up to $21 \mathrm{~mm}$ have the supratemporal canal incomplete. Some specimens from 21-25 $\mathrm{mm}$ have the supratemporal canal complete and others incomplete. Those $25 \mathrm{~mm}$ and larger have complete supratemporal canals (incomplete canals in only four adults). The situation is more complex in the North Carolina Bay Lakes and will be discussed under geographic variation, supratemporal canal.

The second character that changes with age is the squamation. As in Perca flavescens (Pycha and Smith, 1955), Micropterus dolomieui (Everhart, 1949:113) and Pomoxis nigromaculatus (Ward and Leonard, 1954), scales first appear on the caudal peduncle at the base of the caudal fin. Later they extend forward along the lateral line and then spread dorsally and ventrally. Sixteen larvae $(9.1-11.1 \mathrm{~mm})$ taken on May 16 and 17, 1958 in New Jersey (CU 32725 and CU 32739) completely lack scales. Four specimens (13.3-14.9 mm) from Lake Ronkonkoma, N. Y., taken on July 6, 1956 (CU 30279) also lacked scales. Two specimens (13.4 mm) taken from Lake Ronkonkoma on Aug. 3, 1956 (CU 30347 ) had 

TARLE 18.
Number of total lateral-line scales in Etheostoma fusiforme

\begin{tabular}{|c|c|c|c|c|c|c|c|c|c|c|c|c|c|c|c|c|c|c|c|c|c|c|c|c|c|c|c|c|}
\hline Drainage & 40 & 41 & 42 & 43 & 44 & 45 & 46 & 47 & 48 & 49 & 50 & 51 & 52 & 53 & 54 & as & 58 & 67 & 58 & 50 & 60 & 61 & 62 & 63 & $\mathrm{~N}$ & 8 & SD & 816 \\
\hline $\begin{array}{l}\text { t. fusiforme } \\
\text { Ogunguit }\end{array}$ & & & & & & 1 & $\frac{2}{1}$ & $\frac{2}{2}$ & 3 & 1 & $\frac{2}{3}$ & 3 & i & 1 & - & 1 & & & & & & & & & 12 & $\begin{array}{l}49.08 \\
49.75\end{array}$ & $\frac{2.71}{241}$ & .25 \\
\hline & & & & & 1 & 1 & 8 & 6 & 6 & 13 & $\begin{array}{c}1 \\
13\end{array}$ & $1 \frac{2}{15}$ & 8 & 7 & 10 & 5 & 1 & & & & & & & & 3 & $\begin{array}{l}50.67 \\
50.39\end{array}$ & $2 \overline{73}$ & $\frac{10}{28}$ \\
\hline $\begin{array}{l}\text { Ierrimack } \\
\text { Ipswich } \\
\text { Nass. Bay }\end{array}$ & & & & & $\pi$ & & & 4 & 5 & 7 & $\frac{5}{7}$ & $\begin{array}{l}5 \\
3 \\
3\end{array}$ & $\begin{array}{l}5 \\
3\end{array}$ & $\frac{1}{5}$ & $\begin{array}{l}1 \\
2\end{array}$ & 三 & ${ }_{1}^{1}$ & - & 1 & & & & & & $\begin{array}{l}34 \\
27\end{array}$ & $\begin{array}{l}49.97 \\
51.48\end{array}$ & $\frac{2.12}{2.33}$ & .36 \\
\hline $\begin{array}{l}\text { Mass. Bay } \\
\text { Neponset } \\
\text { North R. }\end{array}$ & & & & & & & & $\frac{2}{1}$ & 3 & 1 & $\frac{1}{5}$ & i & 3 & $\frac{1}{1}$ & 2 & 2 & & & $x$ & & & & & & 22 & 50.06 & 2.38 & 51 \\
\hline $\begin{array}{l}\text { North R. } \\
\text { Mills R. }\end{array}$ & & & & & 2 & 3 & 3 & $\begin{array}{l}1 \\
9\end{array}$ & 20 & $\overline{17}$ & 10 & $10^{2}$ & $\begin{array}{l}1 \\
4\end{array}$ & ${ }_{1}^{1}$ & 2 & & & & & & & & & & 81 & $\begin{array}{l}50.22 \\
48.84\end{array}$ & $\begin{array}{l}1.86 \\
2.03\end{array}$ & .62 \\
\hline & 1 & 1 & 2 & 1 & 3 & 2 & $\frac{1}{3}$ & $\frac{1}{2}$ & 6 & $\frac{12}{2}$ & 12 & 17 & $2 \mathrm{i}$ & 26 & 21 & 5 & 11 & 1 & 2 & 1 & 1 & & & & 138 & 62.34 & $\frac{5.50}{250}$ & 21 \\
\hline $\begin{array}{l}\text { Weweantic R. } \\
\text { Taunton K. }\end{array}$ & & $x^{2}$ & & & 1 & i & 3 & 3 & 4 & $\frac{2}{2}$ & 2 & 1 & 1 & 2 & & & & & & & & & & & $\frac{1}{2}$ & 48.5 & 2.54 & 60 \\
\hline $\begin{array}{l}\text { Taunton IR. } \\
\text { Seekonk }\end{array}$ & & & & & & & 1 & $\overline{1}$ & 三 & $\frac{2}{4}$ & $\frac{2}{2}$ & $\frac{12}{7}$ & $\frac{5}{5}$ & $\begin{array}{l}6 \\
4\end{array}$ & $\begin{array}{l}3 \\
1\end{array}$ & 1 & - & 1 & & & & & & & $\begin{array}{l}35 \\
26\end{array}$ & $\begin{array}{l}51.34 \\
51.04\end{array}$ & $\frac{2.57}{2.05}$ & 43 \\
\hline $\begin{array}{l}\text { Pataganset L. } \\
\text { Ronkonkoma L. }\end{array}$ & & & & & & & & & & & 1 & $\overline{1}$ & $\frac{2}{5}$ & $\frac{1}{7}$ & 3 & $\overline{10}$ & $16^{3}$ & 1 & 2 & & & & & & 13 & 5462 & 2,47 & 68 \\
\hline & & & & & & & 1 & - & 3 & 1 & 4 & 11 & 25 & 26 & 29 & 23 & $\begin{array}{l}16 \\
22\end{array}$ & 13 & $\frac{1}{5}$ & $\stackrel{4}{8}$ & $\frac{3}{2}$ & & 2 & & 173 & $\begin{array}{l}55.71 \\
5+13\end{array}$ & $\begin{array}{l}2.43 \\
2.49\end{array}$ & 19 \\
\hline $\begin{array}{l}\text { Raritan } \\
\text { Coastal N.J. }\end{array}$ & & 3 & 3 & 7 & 17 & 19 & ${ }_{23}^{1}$ & $\overline{18}$ & 11 & $11^{3}$ & $\stackrel{3}{3}^{2}$ & 7 & 14 & $\frac{13}{3}$ & 1 & & 3 & & 1 & & & & & & $\begin{array}{r}56 \\
132\end{array}$ & $\begin{array}{l}52.50 \\
465\end{array}$ & $\frac{2.02}{2}$ & $\frac{27}{24}$ \\
\hline $\begin{array}{l}\text { Delaware in, } \\
\text { Ceasta }\end{array}$ & & & 2 & - & 3 & 7 & 11 & 9 & 8 & 11 & 7 & 7 & 2 & & & & & & & & & & & & 67 & 4768 & 2.72 & .24 \\
\hline $\begin{array}{l}\text { Del. Md. } \\
\text { ake Bay }\end{array}$ & & & & & & & $\frac{2}{2}$ & $\begin{array}{l}6 \\
2 \\
2\end{array}$ & ${ }_{8}^{10}$ & $\frac{10}{7}$ & $\begin{array}{l}11 \\
16\end{array}$ & 12 & ${ }_{14}^{4}$ & $11^{4}$ & $\frac{2}{8}$ & $\frac{1}{6}$ & $\frac{1}{2}$ & - & 1 & & & & & & 5 & 49.62 & $\begin{array}{l}2.40 \\
0.40\end{array}$ & .32 \\
\hline Potomac & & & & 1 & - & 3 & 6 & $\tilde{3}$ & 3 & 3 & 7 & 3 & 2 & 2 & 1 & & & & 1 & & & & & & 34 & 48.62 & 2.71 & .46 \\
\hline mond & & & & 1 & 2 & 2 & 2 & 3 & ${ }_{2}^{4}$ & 1 & 1 & 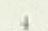 & $\sigma$ & 2 & 1 & & & & & & & & & & $\begin{array}{l}14 \\
13\end{array}$ & $\begin{array}{l}46.57 \\
49092\end{array}$ & $\begin{array}{l}160 \\
200\end{array}$ & 43 \\
\hline $\begin{array}{l}\text { Chowan } \\
\text { Chower }\end{array}$ & & 1 & 1 & 3 & 5 & $\overline{4}$ & $\overline{8}$ & 11 & $20^{2}$ & ${ }_{17}^{17}$ & 13 & 11 & 7 & 3 & $\frac{1}{2}$ & & & & & & & & & & 115 & $\begin{array}{r}7.9 .12 \\
48.38\end{array}$ & & 24 \\
\hline toanoke & & & & 1 & 1 & 5 & 2 & 15 & 19 & 16 & 7 & 15 & 8 & 6 & 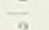 & 3 & & & & & & & & & gs & 49.17 & 244 & 25 \\
\hline $\begin{array}{l}\text { Seuse } \\
\text { allik } \mathrm{I} \text {. }\end{array}$ & & & ? & i & $\frac{1}{2}$ & $\begin{array}{l}1 \\
4\end{array}$ & $\begin{array}{l}6 \\
8\end{array}$ & 7 & 11 & 14 & $\begin{array}{l}6 \\
6 \\
6\end{array}$ & $\begin{array}{l}3 \\
3\end{array}$ & $\stackrel{2}{1}$ & $\overline{2}$ & $\frac{2}{1}$ & 1 & & & & & & & & & $\frac{50}{57}$ & $\begin{array}{l}48.28 \\
48.18\end{array}$ & $\begin{array}{l}2.72 \\
1.46\end{array}$ & .38 \\
\hline singletary L. & & & & & & - & 4 & $\frac{7}{11}$ & 6 & 7 & 12 & $\ddot{b}$ & 9 & 7 & $\frac{1}{2}$ & $\overline{1}$ & 1 & & & & & & & & 52 & 50.65 & 1.98 & .27 \\
\hline $\begin{array}{l}\text { Salters L. } \\
\text { Jones L. }\end{array}$ & & & & & 1 & $\overline{1}$ & $\frac{4}{2}$ & $\frac{11}{7}$ & 11 & $\frac{7}{7}$ & 12 & $14^{7}$ & 5 & $\frac{1}{3}$ & $\frac{2}{2}$ & $\begin{array}{l}1 \\
1\end{array}$ & $\overline{1}$ & 1 & & & & & & & 70 & $\begin{array}{r}49283 \\
49963\end{array}$ & $\begin{array}{l}2.06 \\
2.22\end{array}$ & .27 \\
\hline White L. & & & $\approx$ & & 2 & 3 & 11 & 13 & 20 & 24 & 20 & 22 & 19 & 9 & 8 & 2 & 2 & - & 1 & & & & & & 174 & 49.75 & 2.48 & 19 \\
\hline $\begin{array}{l}\text { otber Cane Fear } \\
\text { Waccamaw }\end{array}$ & & & $=$ & $\overline{4}$ & $\frac{1}{3}$ & 2 & 2 & $\frac{2}{5}$ & 7 & 4 & & 13 & & $\frac{1}{5}$ & 5 & - & 1 & & & & & & & & 71 & $\begin{array}{r}47.85 \\
45.68\end{array}$ & 3.00 & .37 \\
\hline $\begin{array}{l}\text { (. Barratti } \\
\text { Pee Dee }\end{array}$ & & & & & & & 9 & 3 & 3 & 7 & 7 & 6 & 4 & 2 & 3 & 3 & 4 & - & - & - & 1 & & & & & & & \\
\hline anter & & & & & 2 & 1 & $\mathrm{i}$ & 5 & 6 & 15 & 4 & 11 & 8 & 8 & 2 & 1 & 1 & & & - & & & & & a & & & 31 \\
\hline $\begin{array}{l}\text { Ealisto } \\
\text { Combaliee-Broad }\end{array}$ & & & & & & & & & 4 & $\frac{2}{3}$ & $\frac{1}{3}$ & $\frac{3}{2}$ & $\frac{1}{2}$ & 1 & $\frac{3}{2}$ & $\overline{1}$ & 1 & & & & & & & & 16 & 0 & $\frac{261}{2}$ & 65 \\
\hline $\begin{array}{l}\text { Savannah } \\
\text { Gaver }\end{array}$ & & & & & & 2 & 4 & 5 & 15 & 11 & 17 & 21 & 20 & 22 & 16 & $1 \frac{\hat{7}}{7}$ & 12 & 25 & 6 & 7 & 3 & 3 & 3 & 1 & 21 & 53.16 & 3.78 & 26 \\
\hline $\begin{array}{l}\text { Eeechee } \\
\text { Itamalia-Satilla }\end{array}$ & & & & & & & 1 & $\frac{2}{4}$ & 3 & $i_{1}^{2}$ & $1^{6}$ & 3 & $\frac{5}{7}$ & $\stackrel{1}{8}$ & $\frac{1}{3}$ & $=$ & $\frac{2}{2}$ & $=$ & - & 1 & & & & & 72 & 50.85 & $\frac{2.97}{2.97}$ & .57 \\
\hline & & & & 1 & 2 & 1 & 3 & $\frac{1}{5}$ & 5 & 5 & + & 5 & 6 & i & & & - & & & & & & & & 41 & $\begin{array}{l}49.10 \\
\end{array}$ & $\frac{2}{2} 72$ & 37 \\
\hline $\begin{array}{l}\text { t. Jo } \\
\text { t. Cl. }\end{array}$ & & & & & 1 & - & 2 & 1 & $\frac{2}{7}$ & 6 & 9 & 17 & 15 & 15 & 16 & 9 & 5 & 6 & 4 & 2 & 1 & & & & 108 & & 266 & 26 \\
\hline $\begin{array}{l}\text { St. Clowd } \\
\text { Orlando }\end{array}$ & & & & & $\frac{1}{7}$ & 9 & 4 & $1 \frac{2}{4}$ & 13 & 11 & 20 & 10 & 10 & 3 & $\overline{1}$ & $\frac{1}{5}$ & $\begin{array}{l}1 \\
1\end{array}$ & & & & & & & & 100 & $4 !$ & $\begin{array}{l}2.47 \\
2.86\end{array}$ & $\begin{array}{l}40 \\
28\end{array}$ \\
\hline Oklawalia-St. Jobny & & & & & 1 & 0 & 1 & $\div$ & 2 & 3 & 4 & 7 & 5 & 7 & 11 & 3 & 5 & 5 & 2 & - & 1 & & & & & & & 39 \\
\hline iobee & & & & 2 & 1 & -2 & $\frac{2}{4}$ & 1 & 3 & 4 & $\frac{9}{5}$ & 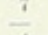 & $\frac{6}{3}$ & $\frac{6}{2}$ & 2 & - & 2 & & & & & & & & t & & & 40 \\
\hline Tamp & & & & & & & 5 & 2 & 4 & 1 & 1 & 4 & 2 & - & 2 & - & 1 & - & - & 1 & & & & & 21 & 30 & 3.49 & .76 \\
\hline chee-Waccasass & & & & & 1 & 1 & $=$ & $\frac{1}{1}$ & a & 4 & 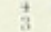 & 9 & $\stackrel{t}{0}$ & $\begin{array}{l}1 \\
9 \\
9\end{array}$ & $\begin{array}{l}1 \\
9\end{array}$ & $\overline{6}$ & 7 & $\frac{1}{3}$ & 6 & 2 & 2 & & & & 74 & 80 & 8 & 67 \\
\hline finnee & & & & & 1 & & & 3 & i & 2 & 4 & 2 & 1 & 2 & 4 & & & & & & & & & & & & & 57 \\
\hline Crys & & & 2 & 2 & 1 & 5 & 4 & 4 & 16 & & & 8 & $\frac{1}{5}$ & 4 & 1 & & & & & & & & & & & & & .45 \\
\hline ce & & & & & & & 1 & & & 9 & ${ }_{3}^{11}$ & 8 & 4 & 6 & $\frac{1}{2}$ & $\sqrt{2}$ & i & & & & & & & & & & & 31 \\
\hline lay-st, Marks & & & & 1 & - & 3 & 5 & 9 & 11 & 9 & 14 & 11 & 8 & 12 & 8 & 1 & 1 & 1 & - & - & 1 & & & & & & & ${ }_{60}^{58}$ \\
\hline & & & & & 1 & & 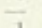 & 3 & 2 & 3 & 8 & \pm & 8 & 5 & 1 & 2 & 1 & 1 & & & & & & & 3 & & & 42 \\
\hline $\begin{array}{l}\text { Choctawhatebee-Perdido } \\
\text { Mobllemay }\end{array}$ & & & & 1 & & & & & i & 9 & + & 2 & $\frac{2}{2}$ & 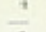 & 1 & - & 1 & - & - & - & 1 & & & & 8 & 0 & 2.43 & $\begin{array}{r}.41 \\
1.30\end{array}$ \\
\hline $\begin{array}{l}\text { Mobile Bny } \\
\text { Miss. Sound }\end{array}$ & & & & & & & & & 1 & - & 1 & 1 & $=$ & 1 & i & - & 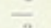 & 1 & & 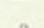 & & & & & & 52.17 & 3.06 & \\
\hline $\begin{array}{l}\text { Pear1-Pontebartrain } \\
\text { Yaxoo }\end{array}$ & & & & & & & & & & & & 2 & 4 & 6 & if & 4 & 3 & 4 & 1 & 3 & - & & & & $\begin{array}{l}39 \\
1\end{array}$ & 55.10 & 2.80 & 45 \\
\hline $\begin{array}{l}\text { Reelfoot L. } \\
\text { Red }\end{array}$ & & & & & & & & & & & & 1 & 1 & 4 & 1 & $\frac{1}{5}$ & 5 & 4 & 6 & 1 & - & - & - & 1 & 31 & 35.68 & 2.59 & 46 \\
\hline rench Brond & & & & & & 1 & 1 & - & 5 & 4 & 6 & 9 & 7 & 2 & 5 & 3 & 2 & & & & & & & & 45 & 51.78 & 2.54 & 38 \\
\hline
\end{tabular}

TABLE 19.

Number of pored lateral-line scales in Etheostoma fusiforme

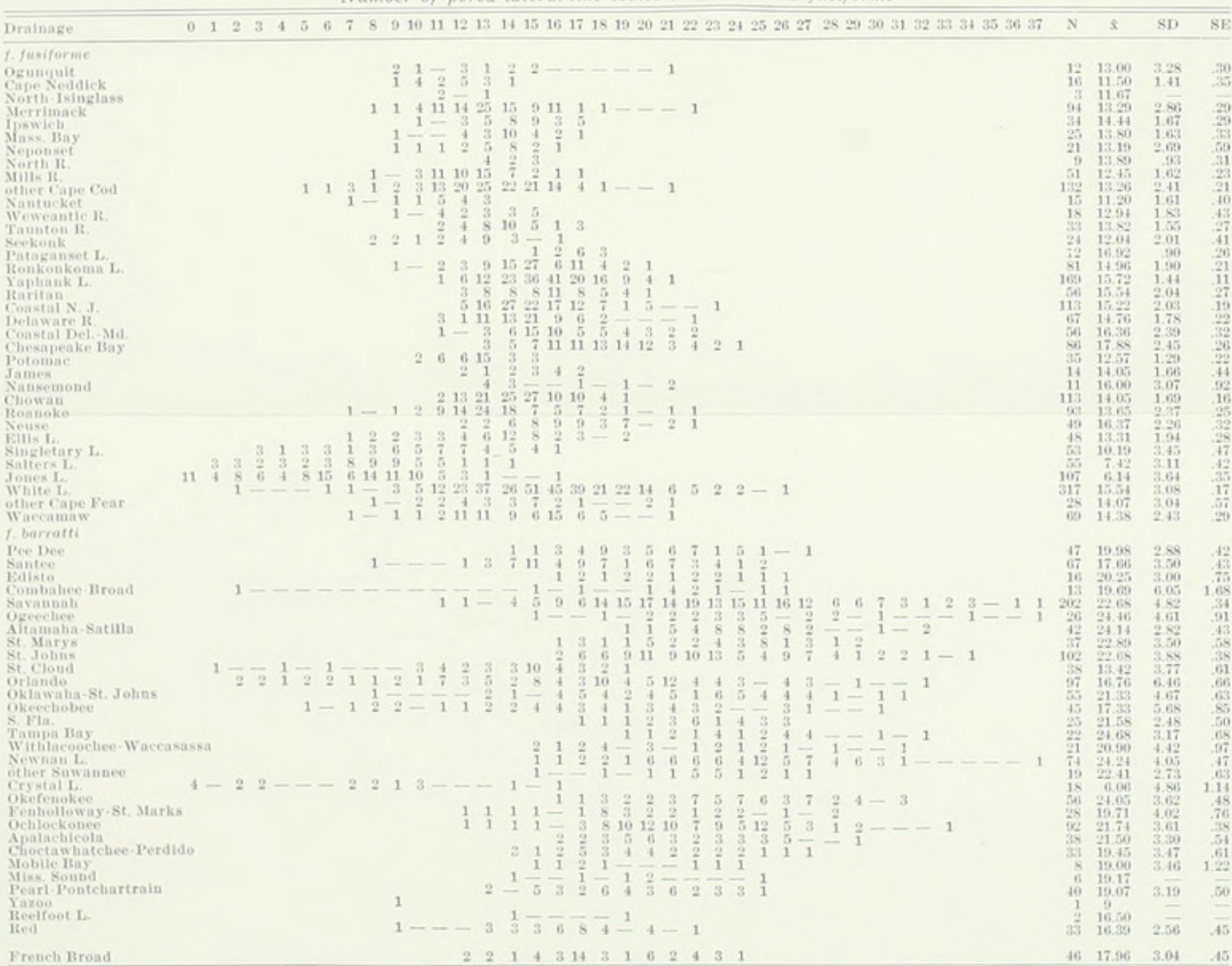



TABLE 20.

Number of first dorsal spines in Etheostoma fusiforme

\begin{tabular}{|c|c|c|c|c|c|c|c|}
\hline Drainage & 8 & 9 & 10 & 11 & 12 & 13 & $\overline{\mathrm{x}}$ \\
\hline \multicolumn{8}{|l|}{ f. fusiforme } \\
\hline Ogunquit & & 2 & 9 & - & 1 & & 10.00 \\
\hline Cape Neddick & & 2 & 3 & 1 & & & $\begin{array}{r}9.83 \\
9.00\end{array}$ \\
\hline North-Isinglass & & 3 & & & & & 9.00 \\
\hline Merrimack & & 15 & 53 & 26 & 1 & & $\begin{array}{r}10.14 \\
9.76\end{array}$ \\
\hline Ipswich & & 12 & 18 & 4 & & & 9.76 \\
\hline Mass. Bay & & 2 & 20 & 3 & 2 & & 10.19 \\
\hline Neponset & & 3 & 16 & 3 & & & 10.00 \\
\hline North & & 2 & 6 & 1 & & & 9.89 \\
\hline Mills & & 1 & 5 & 6 & & & $\begin{array}{l}10.42 \\
0.70\end{array}$ \\
\hline other Cape Cod & 5 & 49 & 66 & 16 & 2 & & $\begin{array}{l}9.72 \\
8.25\end{array}$ \\
\hline Nantucket & 12 & 4 & & & & & $\begin{array}{l}8.25 \\
9.38\end{array}$ \\
\hline Weweantic & & 14 & $\begin{array}{r}6 \\
21\end{array}$ & 1 & & & $\begin{array}{l}9.38 \\
9.89\end{array}$ \\
\hline Taunton & & 9 & $\begin{array}{l}21 \\
19\end{array}$ & 5 & & & $\begin{array}{l}9.89 \\
9.78\end{array}$ \\
\hline $\begin{array}{l}\text { Seekonk } \\
\text { Pataganset L. }\end{array}$ & & $\begin{array}{l}7 \\
5\end{array}$ & $\begin{array}{r}19 \\
8\end{array}$ & 1 & & & $\begin{array}{l}9.78 \\
9.62\end{array}$ \\
\hline Ronkonkoma L. & & 4 & 36 & 10 & 1 & & $\begin{array}{r}9.62 \\
10.16\end{array}$ \\
\hline Yaphank L. & & 13 & 19 & 1 & & & 9.64 \\
\hline Raritan & 8 & 21 & 19 & 7 & & & 9.45 \\
\hline Coastal N. J. & 4 & 34 & 62 & 19 & 2 & & 9.84 \\
\hline Delaware & & 10 & 33 & 15 & 1 & & 10.12 \\
\hline Coastal Del.-Md. & & & 2 & 4 & & & 10.67 \\
\hline Chesapeake Bay & & 8 & 47 & 20 & & & 10.16 \\
\hline Potomac & & 2 & 14 & 1 & & & 9.94 \\
\hline James & & & 14 & & & & 10.00 \\
\hline Nansemond & 1 & 8 & 3 & & & & 9.17 \\
\hline Chowan & & & 11 & 68 & 34 & 2 & 11.23 \\
\hline Roanoke & 1 & 27 & 46 & 7 & 1 & & 9.76 \\
\hline Neuse & & 13 & 27 & 8 & & & 9.90 \\
\hline Ellis L. & & 26 & 28 & 3 & & & 9.60 \\
\hline Singletary L. & 12 & 23 & 8 & & & & 8.91 \\
\hline Salters L. & 14 & 20 & 2 & & & & 8.67 \\
\hline Jones L. & 12 & 27 & 6 & & & & 8.87 \\
\hline White L. & 4 & 28 & 29 & 4 & & & 9.51 \\
\hline other Cape Fear & & 9 & 10 & 2 & & & 9.67 \\
\hline Waccamaw & 3 & 18 & 27 & 15 & & & 9.86 \\
\hline \multicolumn{8}{|l|}{ f. barratti } \\
\hline Pee Dee & 1 & 13 & 23 & 11 & 1 & & 9.96 \\
\hline Santee & 2 & 13 & 42 & 11 & 1 & & 9.94 \\
\hline Edisto & & 1 & 13 & 2 & & & 10.06 \\
\hline Combahee-Broad & & & 10 & 4 & & & 10.29 \\
\hline Savannah & & 13 & 123 & 64 & & & 10.26 \\
\hline Ogeechee & 2 & 2 & 12 & 10 & 1 & & 10.22 \\
\hline Altamaha-Satilla & & 1 & 17 & 15 & 1 & & 10.47 \\
\hline St. Marys & & 2 & 14 & 11 & & & 10.33 \\
\hline St. Johns & & 6 & 23 & 7 & 1 & & 10.08 \\
\hline St. Cloud & & 9 & 24 & 6 & & & 9.92 \\
\hline Orlando & & 2 & 14 & 3 & & & 10.05 \\
\hline Oklawaha-St. Johns & 2 & 7 & 28 & 12 & & & 10.02 \\
\hline Okeechobee & 1 & 12 & 24 & 3 & & & 9.73 \\
\hline S. Fla. & & 2 & 10 & 3 & & & 10.07 \\
\hline Tampa Bay & & 7 & 7 & 2 & & & 9.69 \\
\hline Withlacoochee-Waccasassa & & & 15 & 7 & & & 10.32 \\
\hline Newnan L. & & 3 & 14 & 9 & & & 10.23 \\
\hline Suwannee & & 1 & 15 & 3 & & & 10.11 \\
\hline Crystal L. & 1 & 4 & 7 & 3 & & & 9.80 \\
\hline Okefenokee & & 4 & 29 & 19 & & & 10.29 \\
\hline Fenholloway-St. Marks & 1 & 1 & 17 & 11 & & & 10.27 \\
\hline Ochlockonee & & 4 & 33 & 22 & 1 & & 10.33 \\
\hline Apalachicola & & 2 & 15 & 9 & 2 & & 10.39 \\
\hline Choctawhatchee-Perdido & & 5 & 15 & 14 & 2 & & 10.36 \\
\hline Mobile Bay & & 2 & 4 & 2 & & & 10.00 \\
\hline Miss. Sound & & & 6 & 1 & & & 10.14 \\
\hline Pearl-Pontchartrain & & 9 & 14 & 6 & 1 & & 9.97 \\
\hline Reelfoot L. & & 1 & - & 1 & & & 10.00 \\
\hline Red & & & 10 & 14 & 1 & & 10.64 \\
\hline French Broad & 2 & 15 & 27 & 3 & & & 9.66 \\
\hline
\end{tabular}


TABLE 21.

Number of second dorsal rays in Etheostoma fusiforme

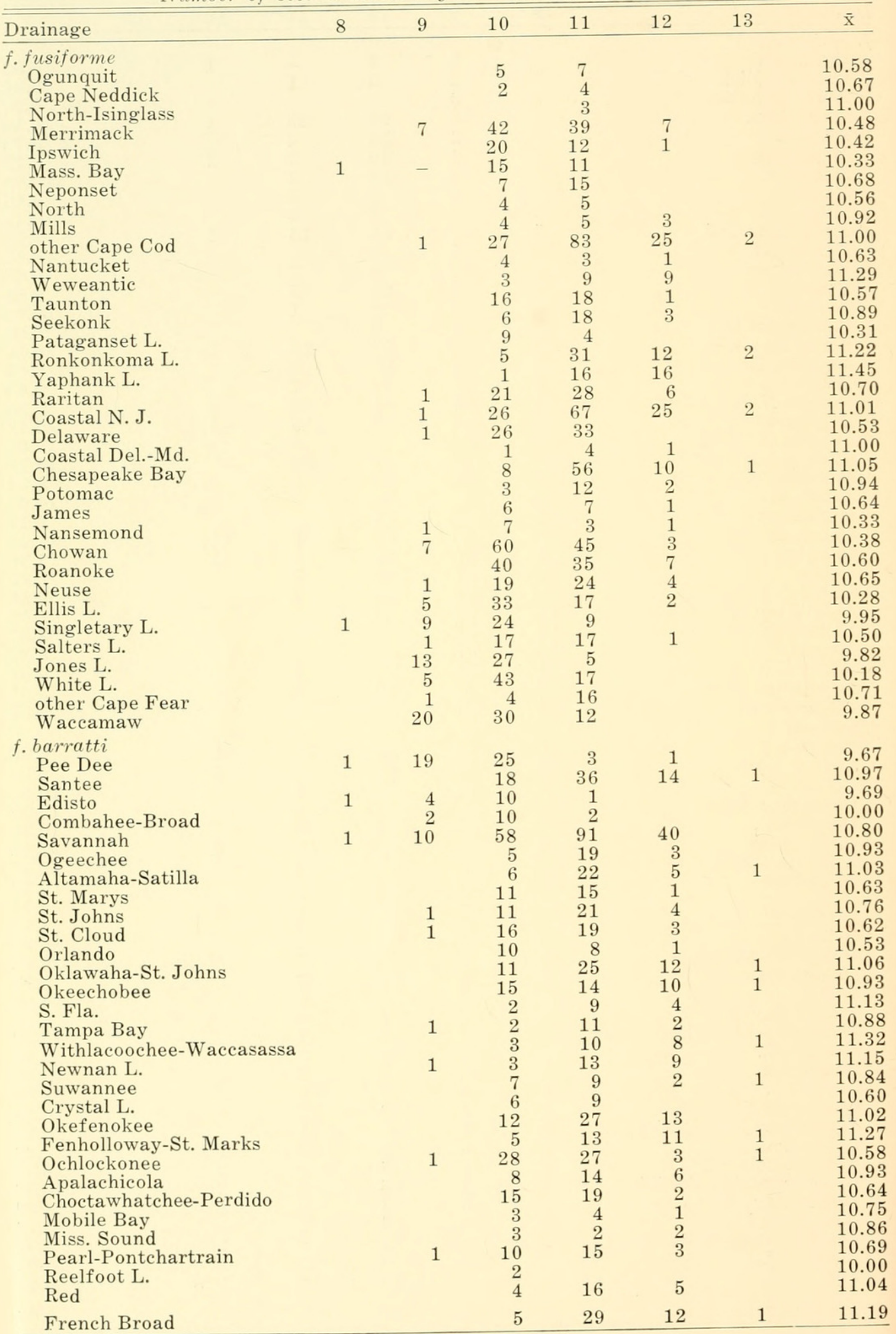


는 ヨ.

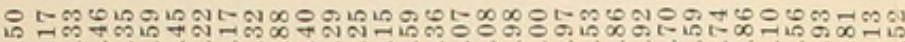

구

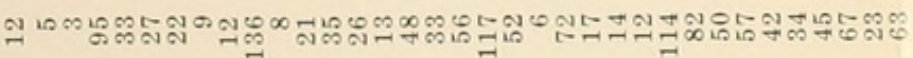

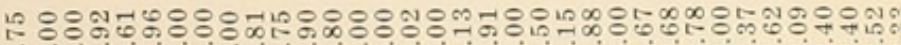

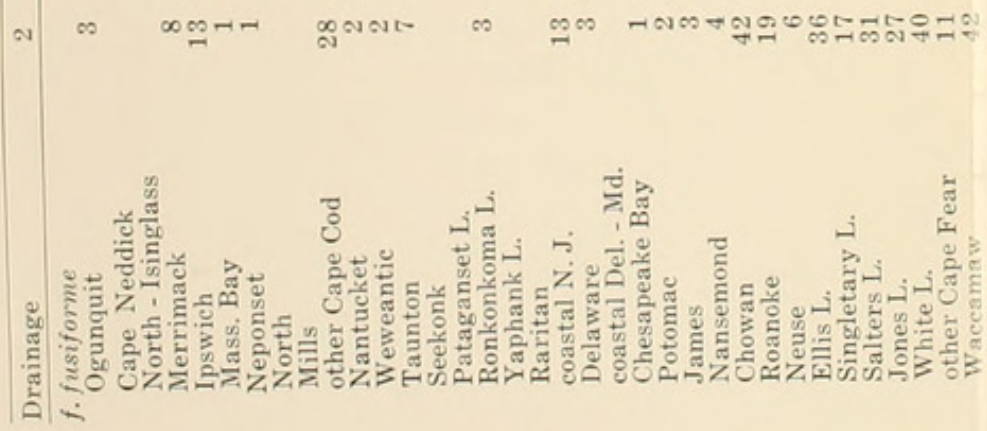

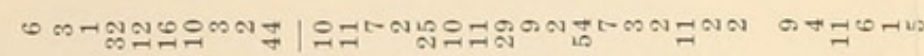
๑ $\nabla$

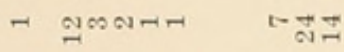

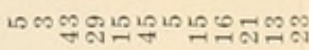
$\operatorname{Nos} \cong \mathrm{N}$ LOS

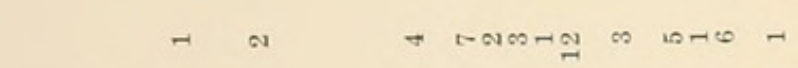

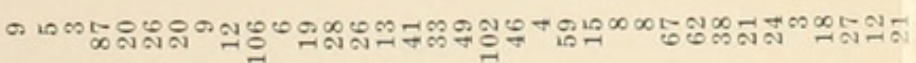

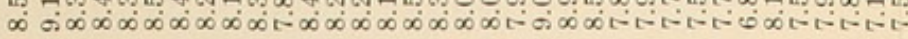

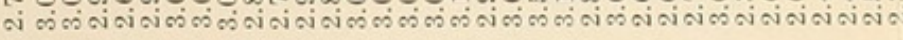

부ำ

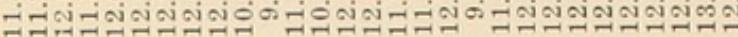

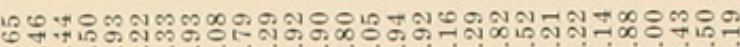

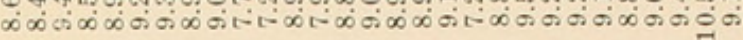

คำ

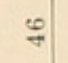

(1)

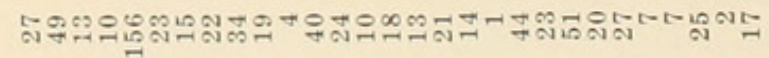

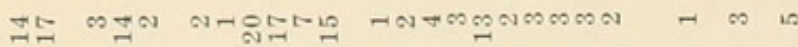

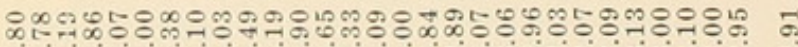

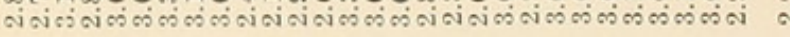
फั00

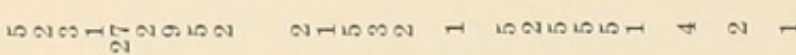

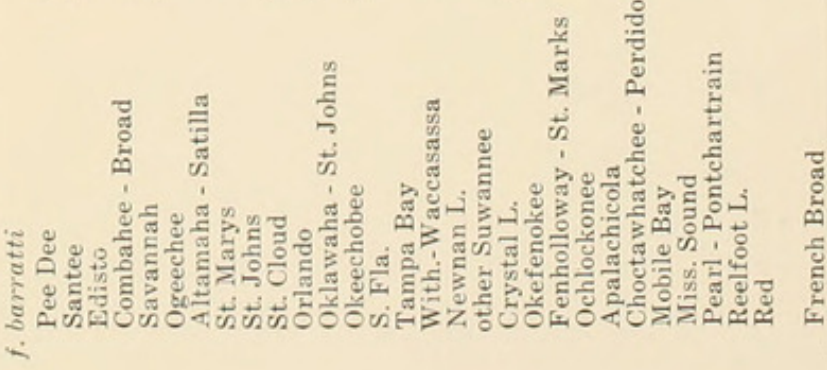



TABLE 23.

Number of anal and pectoral rays in Etheostoma fusiforme

\begin{tabular}{|c|c|c|c|c|c|c|c|c|c|c|c|}
\hline \multirow{2}{*}{ Drainage } & \multicolumn{7}{|c|}{ Anal Rays } & \multicolumn{4}{|c|}{ Pectoral Rays } \\
\hline & 5 & 6 & 7 & 8 & 9 & 10 & $\overline{\mathrm{x}}$ & 12 & 13 & 14 & 15 \\
\hline \multicolumn{12}{|l|}{ f. fusiforme } \\
\hline Ogunquit & & 1 & 8 & 3 & & & 7.17 & & & & \\
\hline Cape Neddick & & 1 & 3 & 2 & & & 7.17 & & & & \\
\hline North-Isinglass & & 1 & 2 & & & & 6.67 & & & & \\
\hline Merrimack & 3 & 27 & 52 & 13 & & & 6.79 & 1 & 4 & 1 & \\
\hline Ipswich & & 10 & 21 & 3 & & & 6.79 & & & & \\
\hline Mass. Bay & & 2 & 15 & 10 & & & 7.30 & & & & \\
\hline Neponset & & 2 & 12 & 8 & & & 7.27 & & & & \\
\hline North & & 3 & 4 & 2 & & & 6.89 & & & & \\
\hline Mills & & & 4 & 7 & 1 & & 7.75 & & 5 & 1 & \\
\hline other Cape Cod & & 4 & 71 & 61 & 2 & & 7.44 & & 10 & 5 & \\
\hline Nantucket & & 2 & 3 & 3 & & & 7.13 & & 4 & 4 & \\
\hline Weweantic & & & 8 & 11 & 2 & & 7.71 & & & & \\
\hline Taunton & & 5 & 25 & 5 & & & 7.00 & 3 & 6 & & \\
\hline Seekonk & & 1 & 14 & 12 & & & 7.41 & & & & \\
\hline Pataganset L. & & 3 & 8 & 1 & 1 & & 7.00 & & 4 & 1 & \\
\hline Ronkonkoma L. & & & 7 & 35 & 9 & & 8.04 & & 4 & 3 & \\
\hline Yaphank L. & & & 10 & 13 & 10 & & 8.00 & 1 & 14 & & \\
\hline Raritan & & 8 & 30 & 18 & & & 7.18 & & 8 & & \\
\hline Coastal N.J. & & 15 & 53 & 43 & 10 & & 7.40 & & 9 & 3 & 1 \\
\hline Delaware & 1 & 14 & 31 & 13 & & & 6.95 & & 5 & 1 & \\
\hline Coastal Del.-Md. & & 2 & 2 & 2 & & & 7.00 & 1 & 5 & 2 & \\
\hline Chesapeake Bay & & 2 & $3 \overline{9}$ & $3 \overline{2}$ & 2 & & 7.45 & & 10 & & \\
\hline Potomac & & 1 & 8 & 7 & 1 & & 7.47 & 1 & 6 & & \\
\hline James & & & 9 & 5 & & & 7.36 & & 2 & 1 & \\
\hline Nansemond & & & 7 & 4 & 1 & & 7.50 & & 4 & 1 & \\
\hline Chowan & & 9 & 63 & 39 & 4 & & 7.33 & & 11 & 4 & \\
\hline Roanoke & & 4 & 40 & 32 & 6 & & 7.49 & & 9 & 1 & \\
\hline Neuse & & 5 & 26 & 18 & 1 & & 7.30 & & 9 & 1 & \\
\hline Ellis L. & & & 16 & 32 & 9 & & 7.88 & & & & \\
\hline Singletary L. & & & 15 & 26 & 2 & & 7.70 & & 3 & 2 & \\
\hline Salters L. & & & 7 & 24 & 5 & & 7.94 & & 3 & 2 & \\
\hline Jones L. & & 2 & 14 & 25 & 4 & & 7.69 & 1 & 7 & & \\
\hline White L. & & & 22 & 41 & 2 & & 7.69 & & 4 & 3 & \\
\hline other Cape Fear & & 1 & 14 & 7 & & & 7.27 & & & & \\
\hline Waccamaw & & 2 & 33 & 24 & 3 & & 7.45 & 1 & 9 & & \\
\hline \multicolumn{12}{|l|}{ f. barratti } \\
\hline Pee Dee & 1 & 4 & 25 & 19 & & & 7.27 & & 4 & 1 & \\
\hline Santee & & 1 & 20 & 38 & 9 & 1 & 7.84 & 1 & 9 & 2 & \\
\hline Edisto & & & 2 & 12 & 2 & & 8.00 & 2 & 6 & 1 & \\
\hline Combahee-Broad & & & 3 & 7 & $\overrightarrow{4}$ & & 8.07 & & 7 & 2 & \\
\hline Savannah & & 20 & 55 & 90 & 35 & & 7.70 & & 10 & & \\
\hline Ogeechee & & & 6 & 17 & 4 & & 7.93 & & 4 & 1 & \\
\hline Altamaha-Satilla & & 5 & 16 & 9 & 4 & & 7.35 & & 5 & 4 & 1 \\
\hline St. Marys & & 1 & 9 & 17 & 1 & & 7.64 & 1 & 5 & 1 & \\
\hline St. Johns & & & 14 & 19 & 4 & & 7.73 & 2 & 2 & 2 & \\
\hline St. Cloud & & 1 & 12 & 25 & 1 & & 7.67 & & & & \\
\hline Orlando & & 2 & 12 & 4 & 1 & & 7.21 & & & & \\
\hline Oklawaha-St. Johns & & 3 & 17 & 21 & 8 & & 7.69 & & & & \\
\hline Okeechobee & & & 6 & 24 & 9 & 1 & 8.13 & & 5 & & \\
\hline S. Fla. & & & 7 & 7 & 1 & & 7.60 & 7 & 3 & & \\
\hline Tampa Bay & & 1 & 5 & 8 & 2 & & 7.69 & 1 & 3 & 1 & \\
\hline Withlacoochee-Waccasassa & & & 9 & 9 & 4 & & 7.77 & & 3 & 2 & \\
\hline Newnan L. & & & & 9 & 17 & & 8.65 & 1 & 3 & 1 & \\
\hline Suwannee & & & 10 & 8 & 1 & & 7.53 & 2 & 5 & 1 & \\
\hline Crystal L. & & & 8 & 6 & 1 & & 7.53 & & & 6 & 9 \\
\hline Okefenokee & & & 17 & 32 & 3 & & 7.73 & & 8 & 1 & 1 \\
\hline Fenholloway-St. Marks & & 2 & 15 & 9 & 2 & & 7.39 & 1 & 2 & 6 & \\
\hline Ochlockonee & & 4 & 44 & 12 & & & 7.13 & 1 & 7 & 7 & \\
\hline Apalachicola & & 5 & 18 & 4 & 1 & & 7.04 & & 5 & & \\
\hline Choctawhatchee-Perdido & & 3 & 24 & 8 & & & 7.14 & 2 & 8 & 4 & \\
\hline Mobile Bay & & & 3 & 5 & & & 7.63 & & 2 & 2 & \\
\hline Miss. Sound & & 1 & 3 & 3 & & & 7.29 & 1 & 3 & 2 & \\
\hline Pearl-Pontchartrain & & 2 & 20 & 7 & 1 & & 7.23 & 3 & 11 & 1 & \\
\hline Reelfoot L. & & $\overline{1}$ & - & 1 & & & 7.00 & & 1 & & \\
\hline Red & & 1 & 10 & 13 & 1 & & 7.56 & 1 & 4 & & \\
\hline French Broad & & & 10 & 29 & 8 & & 7.96 & & & & \\
\hline
\end{tabular}


scales along the posterior portion of the lateral line and in others $(16.7 \mathrm{~mm}$ and larger) squamation is nearly complete. In the July 6 collection, squamation is nearly complete in specimens $15.6 \mathrm{~mm}$ and larger.

The pored lateral-line scales do not develop until after the body squamation is nearly complete. Figure 11 shows the change in number of pored lateral-line scales with age in the Long Island population. Small lateral ridges grow higher and higher and finally form the pore by meeting over the middle of the scale. The smallest (15.6 $\mathrm{mm})$ E. f. fusiforme with a fully developed pored scale was taken from Lake Ronkonkoma (CU 30279) on July 6. The pored scales form quite rapidly starting at the anterior part of the lateral line. After about $20 \mathrm{~mm}$ there is little or no change in the number of pored scales (Fig. 11). The development is similar in White Lake, one of the North Carolina Bay Lakes (Fig. 12) but the dark Bay Lakes show a more complicated situation that will be discussed under geographic variation, pored lateralline scales.

Habitat-E. fusiforme fusiforme is found primarily in ponds, swamps, and backwaters of streams. I have taken it only rarely in flowing waters, and then not in abundance. In many areas (e.g., in New Jersey), mill ponds and ponds for cranberry bogs provide an ideal habitat for E. f. fusiforme. Mansueti (1951) found 1,000 specimens after rotenoning such a pond in Maryland.

The bottom at most E, f. fusiforme localities consists of mud or detritus. This is especially true in the realtively few collections in which both Etheostoma olmstedi and E. f. fusiforme were taken. For example, in Lower Lake Yaphank, Long Island, the southern end of the lake is mostly sand bottomed, with some areas of mud and detritus. Seining in the detritus produced only E. f. fusiforme and collecting over the open sand only E. olmstedi. Where both species were taken in streams olmstedi occupied the central sandy areas while $f$. fusiforme was limited to the weedy, mudbottomed backwaters. However, in the absence of olmstedi, as in some of the acid water ponds of the New Jersey Pine Barrens, f. fusiforme may be quite abundant over open sand.

The body of E. f. fusiforme is quite com- pressed, adapted for living in dense aquatic vegetation, while the heavier body of $E$. olmstedi, roughly triangular in cross section, is adapted for living on stream bottoms facing a current. A specimen of E, f. fusiforme, dislodged from its protecting weed bed in the outlet stream of Wildwood Lake, Long Island, was carried downstream by the current, while E. olmstedi maintained its position on the bottom. E. olmstedi also appears to live in more highly oxygenated waters than does $f$. fusiforme.

Although usually reported from acid brown-stained waters, E. f. fusiforme is not limited to such habitats, but is found there for two reasons. It avoids currents, and many of the slow waters on the Coastal Plain are acid and brown-stained. Secondly, most fishes are poorly adapted to this type of habitat and the acid-water fishes (see species associates) avoid competition from other species by living there.

In Maine, Everhart (1950) reported that E. f. fusiforme was "taken in sluggish, lowland streams and mudholes among the vegetation" and Collette (1958) stated that it "is usually found in muddy, swampy areas." In Delaware, Fowler (1911) noted that it was "abundant in almost all lowland fresh waters, at least above tide." Harmic (1952) found that it was "abundant in mill ponds and sluggish waters" in Delaware. Mansueti (1951) described four millponds and a sluggish stream in Maryland where it was taken. In Connecticut, it has been reported from Pataganset Lake, where it was found over muddy bottom among floating marginal vegetation (Webster, 1942, and personal observation). In New Jersey, Smith (1957) reported that it appeared to seek cover in vegetation and detritus to a greater degree than the Johnny darter (E, olmstedi). Smith (1907:269) quoted W. P. Seal to the effect that around Wilmington, N. C., it will "... stand warm and stagnant water better than any other darter I know of." This was also noted by Hubbs and Cannon (1935:67) who referred to a statement by G. S. Myers about E. f. fusiforme around Wilmington, N. C. "... it occurs abundantly in very warm, quiet waters reaching summer temperatures of $85^{\circ}$ to $90^{\circ} \mathrm{F}$. or even more, at the depth of 3 or 4 inches in masses of filamentous algae along banks of 'black water' streams." Bailey (1938:176) seems 


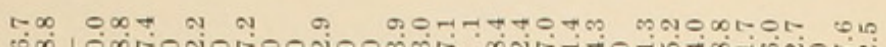

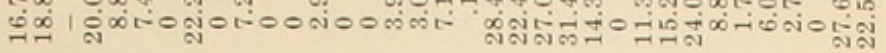
엄 N⿻上丨⿹勹冫欠

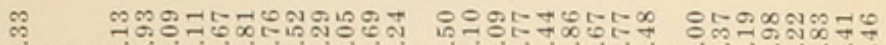

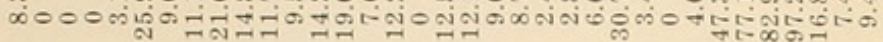

국

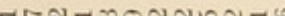

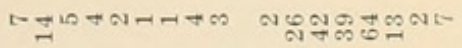

§
로ำ

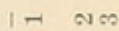

(를

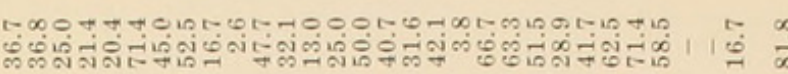

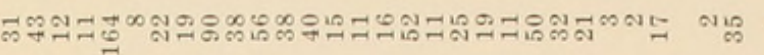

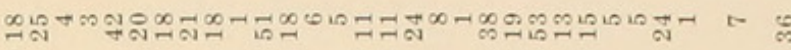

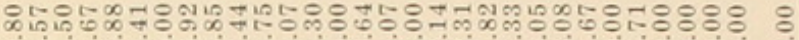

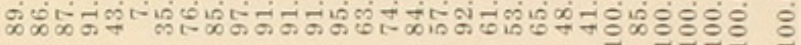

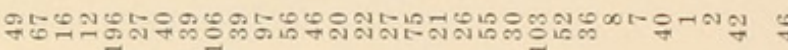

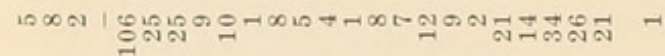

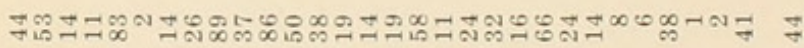
I 1 NーT I - 


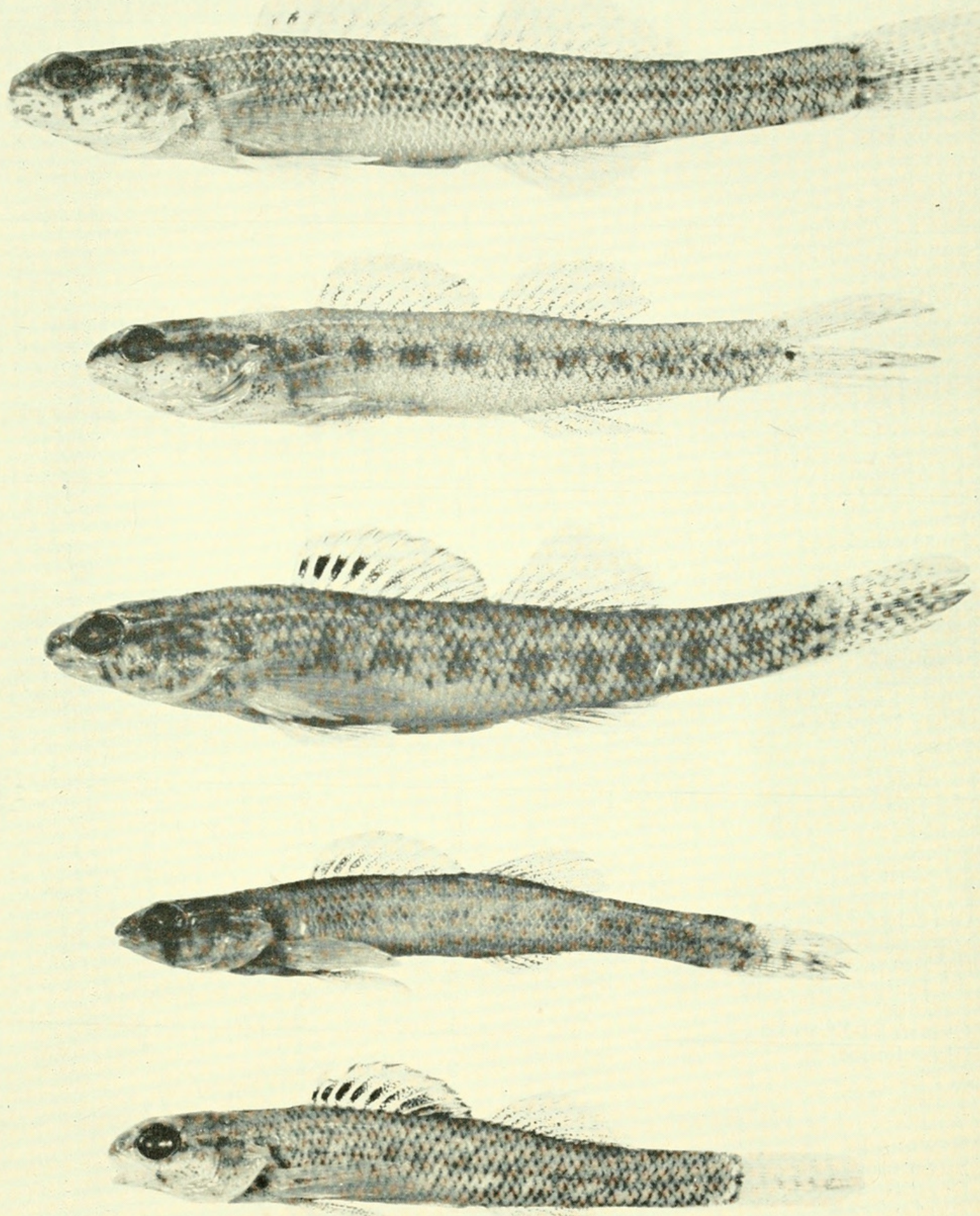

Figure 7. Breeding patterns of male Etheostoma fusiforme fusiforme. (from top to bottom ) CU 31847; 41.3 mm; N.Y., Suffolk Co., Lake Yaphank; Apr. 19, 1958. CU 32725 ; $33.6 \mathrm{~mm}$; N.J., Atlantic Co., Great Egg Harbor dr.; May 16, 1.59. CU 31640 ; 37.4 mm; N.C., Northampton Co., Roanoke dr.; April 4, 1258. CU 25304; $30.4 \mathrm{~mm}$; CU 14302; Co., Jones Lake; Aug. 24-26, 1947. (past maximum breeding pattern) CU 14302 ; 30.3 mm; N.C., Columbus Co., Waccamaw dr.; Mar. 29, 1949. (Photograph
by Donglass M. Payne) 
TABLE 25 .

Squamation of the breast in Etheostoma fusiforme

\begin{tabular}{llllll}
\hline \hline Drainage & I-C & I/PX-C/T & PX-T & X/PX-T & X-T
\end{tabular}

f. fusiforme

Ogunquit

Cape Neddick

Merrimack

Ipswich

Mass. Bay

Neponset

Mills R.

Cape Cod

Weweantic

Taunton

Pataganset L.

Ronkonkoma L.

Yaphank L.

Raritan

Coastal N. J.

Delaware R.

Del.-Md.

Chesapeake

Potomac

James

Nansemond

Chowan

Roanoke

Neuse

Ellis L.

Singletary L.

Jones L.

White Lake

Other Cape Fear

Waccamaw

I-C

$\mathrm{I} / \mathrm{PX}-\mathrm{C} / \mathrm{T}$

f. barratti

Pee Dee

Santee

Edisto

Combahee-Broad

Savannah

Ogeechee

Altamaha-Satilla

St. Marys

St. Johns

Orlando

Oklawaha-St. Johns

Okeechobee

S. Fla.

Tampa Bay

Withlacoochee-Waccasassa

Newnan L.

Suwannee

Crystal L.

Okefenokee

Fenholloway-St. Marks

Ochlockonee

Apalachicola

Choctawhatchee-Perdido

Mobile Bay

Miss. Sound

Pearl-Pontchartrain

Reelfoot L.

Red 
TABLE 26

Parietal squamation in Etheostoma fusiforme (percent of parietal covered with scales)

Drainage 5 - 15- 25- 35- 45- 55- 65- 75- 85-

\section{f. fusiforme}

Ogunquit

Cape Neddick

$\begin{array}{lllllllllll}0 & 10 & 20 & 30 & 40 & 50 & 60 & 70 & 80 & 95 & 100\end{array}$

$\overline{\mathrm{x}}$

Merrimack

Ipswich

Mass. Bay

Neponset

Mills R.

Cape Cod

Nantucket

Weweantic

Taunton

Pataganset L.

Ronkonkoma $\mathrm{L}$.

Yaphank L.

Raritan

Coastal N. J.

Delaware R.

Del.-Md.

Chesapeake

Potomac

James

Nansemond

Chowan

Roanoke

Neuse

Ellis L.

Singletary L.

Salters L.

Jones L.

White L.

Other Cape Fear

Waccamaw

f. barratti

Pee Dee

Santee

Edisto

Combahee-Broad

Savannah

Ogeechee

Altamaha-Satilla

St. Marys

St. Johns

Orlando

Oklawaha-St. Johns

Okeechobee

S. Fla.

Tampa Bay

WithlacoocheeWaccasassa

Newnan L.

Suwannee

Crystal L.

Okefenokee

Fenholloway St. Marks

Ochlockonee

Apalachicola

ChoctawhatcheePerdido

Mobile Bay

Miss. Sound

Pearl-Pontchartrain

6

6

5

9

5

$\begin{array}{rr}1 & 4 \\ 11 & 1\end{array}$

$\begin{array}{ll}1 & 1 \\ 3 & 2\end{array}$

$\begin{array}{ll}3 & 2 \\ 4 & 3\end{array}$

$6 \quad 1$

$\begin{array}{ll}6 & \\ 7 & 10\end{array}$

$10 \quad 3$

24

$4 \quad 7$

$\begin{array}{lll}2 & 5 & 1\end{array}$

$\begin{array}{lll}2 & 7 & 1\end{array}$

43

$\begin{array}{lll}1 & 4 & 3\end{array}$

$\begin{array}{lll}4 & 1 & \\ 5 & 4 & 1\end{array}$

$\begin{array}{lllll}5 & 4 & 1 & & \\ & 3 & 2 & -\end{array}$

$\begin{array}{ll}9 & 1 \\ 6 & 4\end{array}$

516

3
1

18

$\begin{array}{llllll}1 & 8 & & & & \\ & 5 & 9 & 2 & 2 & 1 \\ 2 & 2 & & & & \\ 2 & 9 & 2 & & & \end{array}$

0

0

0

3.00

0

6.00

.63

0

3.00

3.29

1.07

0

4.41

1.73

5.00

4.77

6.88

7.00

3.21

20.00

9.50

13.50

25.83

8.50

11.50

5.71

7.50

16.39

29.61

15.00

17.50

37.50

56.73

30.83

20.83

57.75

51.50

46.50

56.67

79.32

63.33

85.00

63.67

59.17

88.33

73.57

81.50

33.75

31.50

57.50

74.50

71.25

70.83

67.50

27.50

25.83

56.25

87.50

50.50 



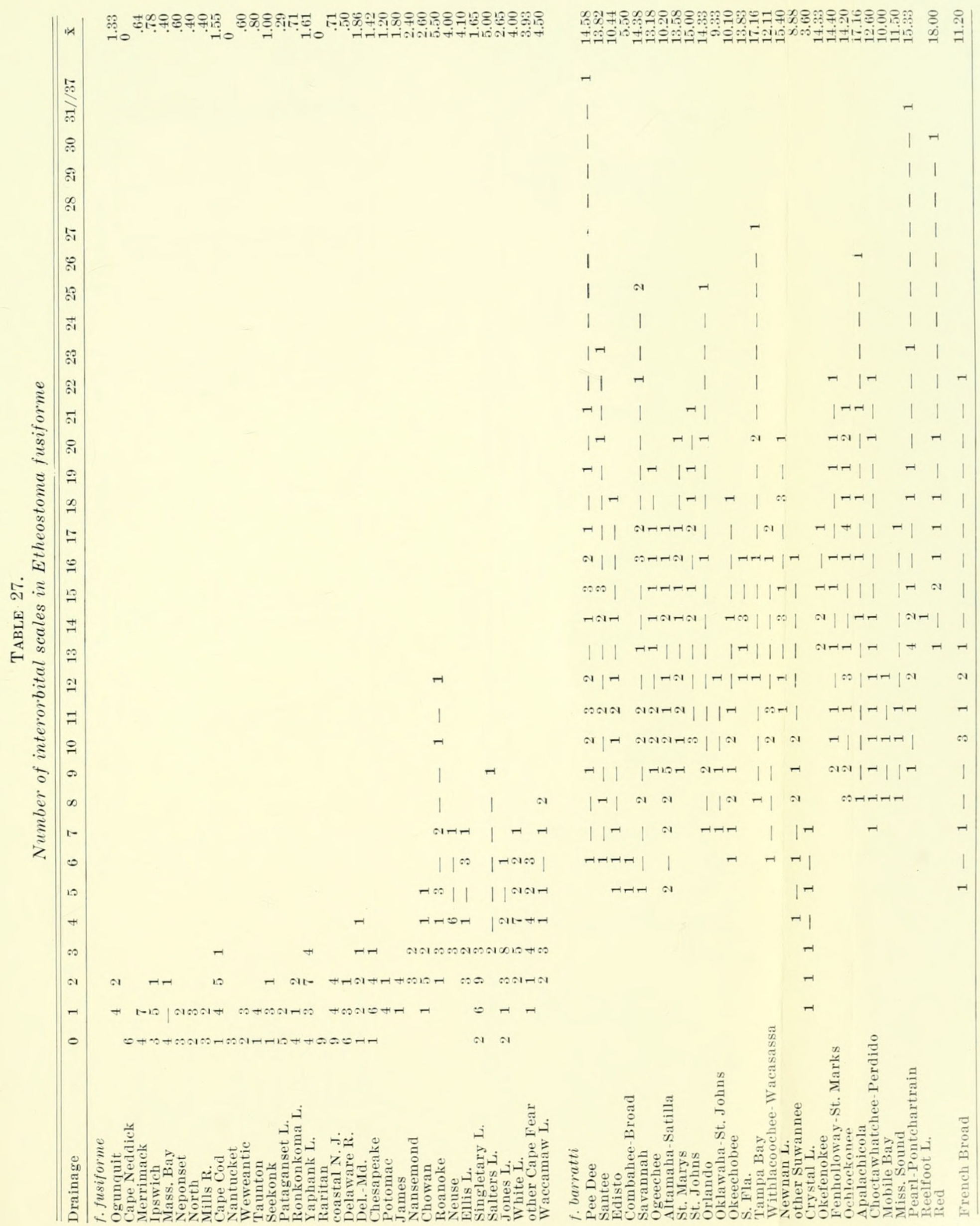




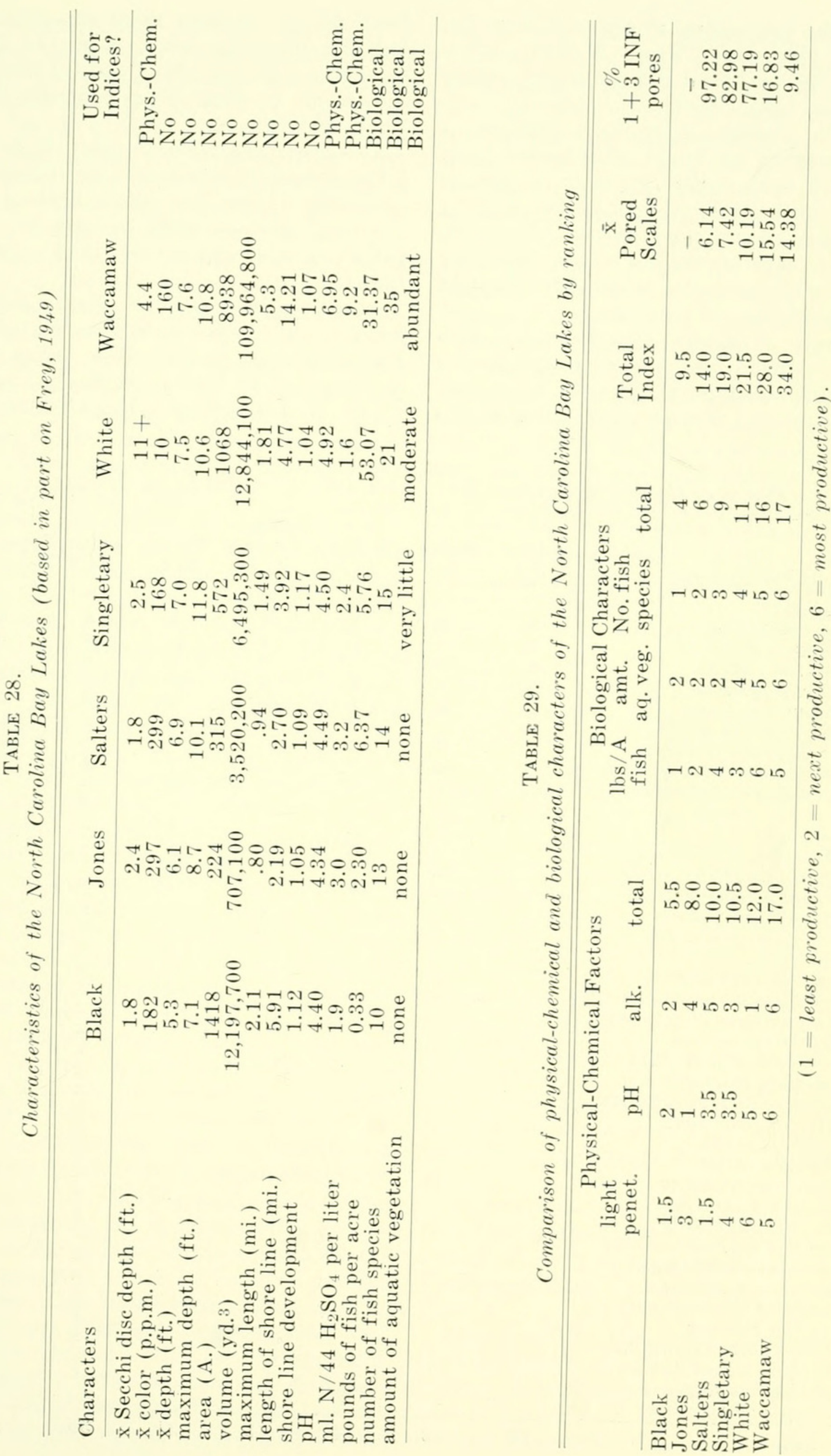
to be the only author to report it from fast waters (Merrimack River, N. H.), as follows: "Where found in streams they usually seek the fastest waters and seclude themselves in clumps of aquatic vegetation.... In lakes they are found in protected coves provided with dense growths of aquatic vegetation." Hubbs and Cannon (1935) gave brief descriptions of the habitat for each of their subspecies of E. fusiforme which verify what has already been brought out concerning their habitat.

Species Associates-Etheostoma f. fusiforme is found over a large range; species associates, therefore, are discussed by regions. I have collected throughout the range of this form and in addition there are published data for the Merrimack River of New Hampshire (Bailey, 1938) and for the lakes and ponds of New Jersey (Smith, 1950, 1953a, 1957).

Esox americanus, Enneacanthus obesus, and Etheostoma f. fusiforme all have similar distributions in New Hampshire: lowland (65313 feet), brown-stained waters with vegetation at least moderately thick (Bailey, 1938 ).

An acid-water fish fauna (Smith, 1953b) exists in the brown-stained waters of the Pine Barrens of southern New Jersey. This is composed of Umbra pygmaea, Ictalurus natalis, Noturus gyrimus, Aphredoderus saya-

TABLE 30.

Fishes of the North Carolina Bay Lakes and of Crystal Lake, Georgia

\begin{tabular}{|c|c|c|c|c|c|c|c|}
\hline $\begin{array}{l}\text { Lake } \\
\text { Index of Productivity }\end{array}$ & $\begin{array}{c}\text { Black } \\
9.5\end{array}$ & $\begin{array}{c}\text { Jones } \\
14.0\end{array}$ & $\begin{array}{l}\text { Salters } \\
19.0\end{array}$ & $\begin{array}{c}\text { Single- } \\
\text { tary } \\
21.5\end{array}$ & $\begin{array}{c}\text { White } \\
28.0\end{array}$ & $\begin{array}{c}\text { Wacca- } \\
\text { maw } \\
34.0\end{array}$ & Crystal L. \\
\hline \multicolumn{8}{|l|}{ Species } \\
\hline Esox americanus & $\mathrm{x}$ & $\mathrm{x}$ & $\mathrm{x}$ & $\mathrm{x}$ & $\mathrm{x}$ & $\mathrm{x}$ & $\mathrm{x}$ \\
\hline Erimyzon succetta & $\mathrm{x}$ & $\mathrm{x}$ & $\mathrm{x}$ & $\mathrm{x}$ & $\mathrm{x}$ & $\mathrm{x}$ & $\mathrm{x}$ \\
\hline Ictalurus natalis & $\mathrm{x}$ & $\mathrm{x}$ & $\mathrm{x}$ & $\mathrm{x}$ & $\mathrm{x}$ & $\mathrm{x}$ & \\
\hline Noturus gyrinus & $\mathrm{x}$ & $\mathrm{x}$ & $\mathrm{x}$ & $\mathrm{x}$ & $\mathrm{x}$ & $\mathrm{x}$ & \\
\hline Gambusia affinis & $\mathrm{x}$ & $\mathrm{x}$ & $\mathrm{x}$ & $\mathrm{x}$ & $\mathrm{x}$ & $\mathrm{x}$ & $\mathrm{x}$ \\
\hline Aphredoderus sayanus & $\mathrm{x}$ & & $\mathrm{x}$ & $\mathrm{x}$ & $\mathrm{x}$ & $\mathrm{x}$ & \\
\hline Ennecanthus gloriosus & $\mathrm{x}$ & $\mathrm{x}$ & $\mathrm{x}$ & $\mathrm{x}$ & $\mathrm{x}$ & $\mathrm{x}$ & $\mathrm{x}$ \\
\hline Centrarchus macropterus & $\mathrm{x}$ & $\mathrm{x}$ & $\mathrm{x}$ & $\mathrm{x}$ & $\mathrm{x}$ & $\mathrm{x}$ & \\
\hline Chaenobryttus gulosus & $\mathrm{x}$ & $\mathrm{x}$ & $\mathrm{x}$ & $\mathrm{x}$ & $\mathrm{x}$ & $\mathrm{x}$ & $\mathrm{x}$ \\
\hline Perca flavescens & $\mathrm{x}$ & $\mathrm{x}$ & $\mathrm{x}$ & $\mathrm{x}$ & $\mathrm{x}$ & $\mathrm{x}$ & \\
\hline Esox niger & & $\mathrm{x}$ & $\mathrm{x}$ & $\mathrm{x}$ & $\mathrm{x}$ & $\mathrm{x}$ & \\
\hline Etheostoma fusiforme & & $\mathrm{x}$ & $\mathrm{x}$ & $\mathrm{x}$ & $\mathrm{x}$ & $\mathrm{x}$ & $\mathrm{x}$ \\
\hline Fundulus notti & & $\mathrm{x}$ & $\mathrm{x}$ & & $\mathrm{x}$ & & $\mathrm{x}$ \\
\hline Micropterus salmoides & & $\mathrm{x}$ & $\mathrm{x}$ & $\mathrm{x}$ & $\mathrm{x}$ & $\mathrm{x}$ & $\mathrm{x}$ \\
\hline Notropis chalybaeus & & & & $\mathrm{x}$ & $\mathrm{x}$ & $\mathrm{x}$ & \\
\hline Lepomis macrochims & & & & $\mathrm{x}$ & $\mathrm{x}$ & $\mathrm{x}$ & $\mathrm{x}$ \\
\hline Amia calva & & & & & $\mathrm{x}$ & $\mathrm{x}$ & \\
\hline Anguilla rostrata & & & & & $\mathrm{x}$ & $\mathrm{x}$ & \\
\hline Lepomis auritus & & & & & $\mathrm{x}$ & $\mathrm{x}$ & \\
\hline Mesogonistius chaetodon & & & & & $\mathrm{x}$ & $\mathrm{x}(?)$ & \\
\hline Lepisosteus osseus & & & & & & $\mathrm{x}$ & \\
\hline Dorosoma cepedianum & & & & & & $\mathrm{x}$ & \\
\hline Erimyzon oblongus & & & & & & $\mathrm{x}(?)$ & \\
\hline Notemigonus crysoleucas & & & & & & $\mathrm{x}$ & $\mathrm{x}$ \\
\hline Notropis petersoni & & & & & & $\mathrm{x}$ & \\
\hline Cyprinus carpio & & & & & & $\mathrm{x}$ & \\
\hline Ictalurus catus & & & & & & $\mathrm{x}$ & \\
\hline Roccus americanus & & & & & & $\mathrm{x}$ & \\
\hline Lepomis gibbosus & & & & & $\mathrm{x}$ & $\mathrm{x}$ & \\
\hline Lepomis punctatus & & & & & & $\mathrm{x}$ & \\
\hline Pomoxis nigromaculatus & & & & & & $\mathrm{x}$ & \\
\hline A cantharchus pomotis & & & & & & $\mathrm{x}$ & \\
\hline Elassoma zonatum & & & & & & $\mathrm{x}$ & \\
\hline Fundulus waccamensis & & & & & & $\mathrm{x}$ & \\
\hline Menidia extensa & & & & & & $\mathrm{x}$ & \\
\hline Etheostoma perlongum & & & & & & $\mathrm{x}$ & \\
\hline Notropis maculatus & & & & & & & $\mathrm{x}$ \\
\hline Labidesthes sicculus & & & & & & & $\mathrm{x}$ \\
\hline Lepomis marginatus & & & & & & & $\mathrm{x}$ \\
\hline Totals & 10 & 13 & 14 & 15 & 21 & 35 & 13 \\
\hline
\end{tabular}


nus, Acantharchus pomotis, Enneacanthus obesus, Mesogonistius chaetodon, and Etheostoma $f$. fusiforme. For the most part these are fishes found at altitudes of 300 feet or less. Smith (1953b) noted for E. obesus that these fishes are found in these areas because competition from other species is greatly reduced or eliminated. In clearer, more alkaline waters of southern New Jersey, other species replace the acid-water fishes: Ictalurus nebulosus replaces $I$. natalis; Enneacanthus gloriosus replaces E. obesus and M. chaetodon; Etheostoma olmstedi replaces E. f. fusiforme; species of Lepomis replace Acantharchus, etc. There are also several wide-ranging species in New Jersey, e.g., Micropterus, s. salmoides and Esox niger which form part of both the acid-water and the alkaline-water faunas.

Smith (1957) reported a change in species composition (or at least abundance) that seems to be correlated with a change in $\mathrm{pH}$. In 1952, when the $\mathrm{pH}$ of Lefferts Lake, New Jersey, was 6.8, Fundulus diaphanus and Notemigonus crysoleucas were common throughout the lake and both $I c$ talurus nebulosus and Lepomis gibbosus were abundant but stunted. In August 1954, the $\mathrm{pH}$ was down to 4.4 and $I$. nebulosus and $L$. gibbosus had become less abundant. In June 1955, when the $\mathrm{pH}$ was 4.1, Notemigonus, I. nebulosus, and L. gibbosus were still less abundant, and Enneacanthus obesus was taken for the first time. In a rotenone sample taken on August 6, 1956, 478 E. obesus and 4 Etheostoma f. fusiforme were taken with only $4 \mathrm{I}$. nebulosus, 13 Notemigonus, 3 L. gibbosus, and 1 Fundulus. On the same day I obtained the following in 15 minutes seining: $32 \mathrm{E}$. f. fusiforme, 19 E. obesus, 3 L. gibbosus. I believe that this is evidence for one of the few times that $\mathrm{pH}$ (or effects connected with $\mathrm{pH}$, such as productivity) can be indicated as important in determining species abundance.

Smith (1907:269) quoted a letter from Seal concerning the associates of E. f. fusiforme in the vicinity of Wilmington, N. C.: "This species is . . . to be found ... where Fundulus, Gambusia, Heterandria, Umbra, Chologaster, Elassoma, Aphredoderus, and sunfishes abound." In New Hampshire, Harrington (1946) reported that E. f. fusiforme was often found on the bottom within an inch or two of foraging bridled shiners, Notropis bifrenatus, and that Enneacantbus obesus was occasionally found in its immediate vicinity. He also noted ( $p$. 55) that when young Notropis bifrenatus first appear they are sometimes found in a chance association with small schools of chub sucker fry (Erimyzon oblongus), golden shiners (Notemigomus crysoleucas) and northern mud darters (E. f. fusiforme). In Delaware, Fowler (1911:13) reported E. f. fusiforme "to be usually associated with Erimyzon, Aphredoderus, Enneacanthus, Mesogonistius and similar fishes." Etheostoma f. fusiforme was taken in 8 of 17 of my collections on the Delmarva Peninsula. Common associates (with number of times taken with E. f. fusiforme and total number of times taken) are: Aphredoderus sayamus (7/8); Lepomis gibbosus (7/14); Anguilla rostrata (6/11); Erimyzon oblongus (5/8); Enneacantbus gloriosus $(5 / 6) ;$ E. obesus (3/4); Acantharchus pomotis (4/4); Notropis chalybaeus (3/3); Mesogonistius chaetodon (2/2); and Noturus gyrimus (3/4).

Predators-Smith (1950) reported Etheostoma f. fusiforme from Esox niger stomachs in a number of acid southern New Jersey lakes: Lake Absegami, Colliers Mills, Farrington Lake, Hanover Lake, Union Lake, and Barnegat Pines Lake (1953a). He also (1957) presented a table of the food of Esox niger from lakes of different acidity for specimens under 6 inches and over 6 inches. Etheostoma f. fusiforme formed $25 \%$ of the food of the smaller Esox in very acid waters $(\mathrm{pH} 4.0-4.8), 15 \%$ in acid waters $(\mathrm{pH} 4.9-5.5), 2 \%$ in slightly acid waters $(\mathrm{pH}$ 5.6-6.9) and $0 \%$ at $\mathrm{pH} 7.0$ and over. For the larger Esox, the figures were $12 \%, 13 \%, 2 \%$, and $0 \%$ for $\mathrm{pH} 7.0$ and over. Harrington (1946) reported E. f. fusiforme from the stomach of a 16-inch Esox niger from the Oyster River, New Hampshire.

Smith (1950) reported E. f. fusiforme from the stomachs of Micropterus s, salmoides (mostly young) in Colliers Mills, Farrington Lake, Parvin Lake, and Union Lake.

Parasites-The only report of parasitism for any species of the subgenus Hololepis is that of Harrington (1946) who found that E. f. fusiforme from the Oyster River of New Hampshire was heavily parasitized 
by glochidia. I have also noted glochidia on a number of specimens.

Acanthocephalans were found with their proboscides imbedded in the stomachs of three E. $f$. fusiforme taken on Long Island (CU 31847). One specimen had two, another five, the third specimen had six, and a fourth specimen had none.

Habits-Specimens collected from Lake Ronkonkoma, Long Island, on April 21, 1956, and brought into the laboratory, began pre-spawning behavior almost at once, although none of the females were distended with eggs. There were two phases to this behavior. First, the male approached the female from the rear, mounted her, and began to "beat" her with his pelvic fins. Usually a female "accepted" this but a male so approached immediately moved away from such attentions. A few weeks later the second phase began; after the male started "beating" a female, she "led" him forward into floating plants at the top of the aquarium. With the male close alongside, she pointed her genital papilla forward and up into a mass of plants, and quivered. On a few occasions two males followed a single female. No fighting or display of territoriality was ever noted. Although no eggs were actually seen being laid, spawning is probably essentially the same in the wild. Fletcher (1957) reported similar behavior in specimens collected on March 27, 1957, in New Jersey. Spawning followed and continued for two days. The eggs were deposited singly on leaves of Myriophyllum and hatched in eight to ten days. Smith (1907) quoted Seal's observations on some specimens taken near Wilmington, N. C., which spawned on the underside of lilies and other plants in a small still-water aquarium.

My collections from New Jersey on May 17,1958 , in four lakes indicated that some specimens had partially completed spawning. Two collections made in the same areas on May 16 and 17, 1959, by N. R. Foster and J. S. Ramsey contained adults and postlarvae as small as $9 \mathrm{~mm}$. A school of 20 to 30 postlarvae was taken by dipnet while free swimming at the surface in six inches to two feet of water over open sand. No other species were closely associated with them (personal communication and field notes of N. R. Foster). On July 6, 1956, I collected 24 young in Lake Ronkonkoma,
Long Island, ranging from 13.3 to $22.0 \mathrm{~mm}$. They were taken about 30 feet out in the lake on an open sandy bottom, in water four to five feet deep. Fletcher's (1957) aquarium specimens were about this size ("3/4 inch") when two months old. Harrington (1947) reported taking "very small fry" of E. f. fusiforme on July 2 and 5, in the Oyster River at Durham, New Hampshire.

Although no aging based on scale reading has yet been done, there is evidence to indicate that a large number, if not most, E. f. fusiforme live only for one year. Most Long Island collections show only one major size class. On July 6, in Lake Ronkonkoma, the 24 specimens which were taken were postlarvae. In November and April all specimens taken in Lake Yaphank were adults.

Everhart (1950) reported that young and adult E. f. fusiforme feed on entomostraca in Maine. This is probably true, but no food studies have yet been made of this subspecies. A $31 \mathrm{~mm}$ specimen from New Jersey had over 130 copepods in its stomach. The intestine was filled with copepod exoskeletons. A large number of specimens from many localities had copepod exoskeletons projecting from the anus. In aquaria, E. f. fusiforme feeds avidly on daphnia, chasing them around the tank in spurts. They will also readily eat anything else of small size that moves. Strange food is inspected; the darter swims to the item, turns its head and looks down on the object with one eye. The object is then taken into the mouth but rejected if not suitable. They have been trained to eat such non-living food as frozen brine shrimp, frozen daphnia, and dried fish food which has been dampened and formed into small pellets. For moderately large darters a supplementary method of feeding was devised. A few pairs of guppies (Lebistes reticulatus) were added to the tanks, and the darters fed on the baby guppies.

A large number of specimens of E. f. fusiforme have been kept in aquaria. They are easy to care for, interesting to watch, and one of the easiest species of darter to transport because of their apparently low oxygen requirement. In aquaria, they spend most of their time either on the bottom or among plants. Specimens often swim up 
to a plant, such as Elodea, and balance themselves there, with pectoral and pelvic fins in front of the plant stem and the rest of the body bent down behind.

Distribution-The range of E, f. fusiforme extends from the southeastern tip of Maine along the Seaboard Lowland section of the New England Province (Fenneman, 1946) south along the Atlantic Coastal Plain below the Fall Line to the Waccamaw River in North Carolina, south of which it is replaced by E. f. barratti (Fig. 8).
The distribution of E.f. fusiforme in New Jersey has been analyzed to ascertain the factors important in limiting its distribution. New Jersey was selected because a large amount of information is available from the publications of Smith $(1950,1952$, $1953 \mathrm{a}, 1953 \mathrm{~b}, 1957)$. The freshwater fish fauna of New Jersey may be divided into three groups: (1) species limited to the sluggish, brown-stained, acid lowland ponds and streams; (2) species of upland, clear, alkaline bodies of water; and (3) species

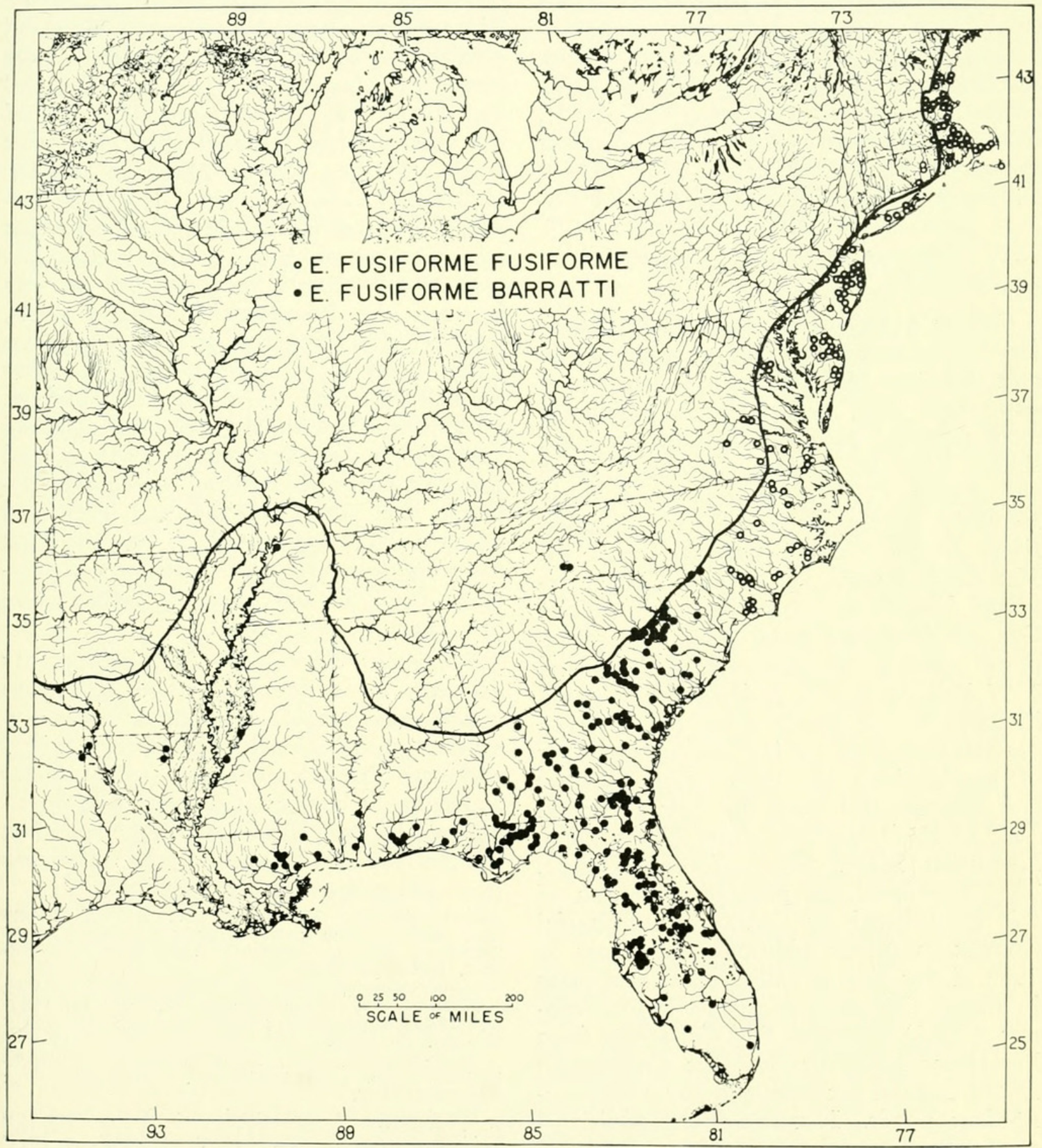

Figure 8. The distribution of Etheostoma fusiforme in relation to the Fall Line. (Based upon specimens examined) 
found throughout the state in both types of situation. Etheostoma f. fusiforme belongs to the acid-water fauna (see species associates) which also includes Enneacantbus obesus, Acantharchus pomotis, Mesogonistius chaetodon, Ictalurus natalis, and Apbredoderus sayamus. These fishes are found in waters with $\mathrm{pH}$ values of 3.7 to 7.6 and usually 4.1 to 5.0 (Smith, 1953b). The average altitudes at which these acid-water species are found in New Jersey are: 52, 51, 98, 54, 64, and 54 feet, respectively. A number of widespread New Jersey species may be found with the preceding six species. These, together with their mean altitudinal ranges and their mean $\mathrm{pH}$ values, where known, are: Erimyzon oblongus (306, 6.70), Notemigonus crysoleucas (352, 7.11), Ictalurus nebulosus (366, 7.12), Noturus gyrimus (271), Esox niger (287, 6.46), Umbra pygmaea (266, 5.62), Anguilla rostrata (246), Micropterus s. salmoides (329, 7.30), Lepomis gibbosus (350), Perca flavescens $(351,7.13)$.

Cooper (1939) first reported E. f. fusiforme from southeastern Maine in the Ogunquit and Cape Neddick rivers, where I have also taken them. Subsequent collections in more northern parts of the state have not shown it to be present. Gordon (1937) and Bailey (1938) reported it in New Hampshire from the North and Isinglass rivers of the Coastal watershed and the Merrimack River. Hubbs and Cannon reported $f$. fusiforme from one pond on Cape Cod (as fusiforme metae-gadi). My collections made in the summers of 1956 and 1957 indicate that E. f. fusiforme is found in most of the ponds along the southern coast of Cape Cod but is absent in a number of ponds along the north shore. Hubbs and Cannon also were the first to report (1935) E. f. fusiforme from Gibbs Pond, Nantucket Island (as fusiforme insulae). They postulated the possible extinction of this form based on Cannon's unsuccessful attempt to collect additional specimens in 1933. I was able to collect eight specimens in a brief visit made in August 1956. Webster (1942) reported E. f. fusiforme from Pataganset Lake for the first Connecticut record, but did not find it in any other Connecticut ponds. I collected ten additional specimens from this lake in November 1957. Additional localities from the Thames drain- age of Connecticut were reported by Behnke and Wetzel (1960). Greeley (1939) was the first to record E. f. fusiforme from Long Island, where the New York Biological Survey obtained it in Lake Ronkonkoma and in two tributaries of the Peconic River: the Little River and Merritt Pond. Further collecting over much of Long Island from the summer of 1956 through 1959 has revealed moderately large $E$. f. fusiforme populations in Lower Lake Yaphank on the Carmans River as well as in Lake Ronkonkoma. Two specimens were also taken in the outet stream of Wildwood Lake in the Peconic River system. Its presence in the Maryland portion of the Delmarva Peninsula was shown by Mansueti (1951) and Mansueti and Elser (1953). My collections extend the known range south to about six miles north of the Virginia-Maryland border. Hubbs and Cannon (1935) described fusiforme atraquae from a Maryland collection from the Potomac River and reported no success in collecting $f$. fusiforme in the area between the Potomac and Neuse rivers. Raney (1950) reported it from the James River where it has been taken well above the Fall Line (Fig. 8). Since then a number of additional specimens have been collected from the James, Nansemond, Chowan, and Roanoke rivers, thus filling in the distributional gap. Frey (1951) and Frey and Bailey (1951) reported E. f. fusiforme (as thermophilum and thermophilum oligoporum) from the Bay Lakes of North Carolina (except Black Lake).

Specimens Examined-Complete locality data are given for only those collections which show range extensions or other significant distributional data. Other collections are listed by drainage, state, county and museum number. Complete data on almost all of the collections may be found in Collette (1960). A total of 3601 specimens from 209 collections was examined.

\footnotetext{
ogunquit Dr. Me.-York Co.: UMMZ 129635 $(12,28-32)$ : Ogunquit R., July 17,1937 . CU $31250(7,21-32)$ : Ogunquit R. on US 1 in Ogunquit, Sept. 18, 1957 .

Cape Neddick Dr., Me.-York Co.: UMMZ 129639 (1, 34); Cape Neddick R., July 17, 1937. CU 31245 (26, 22-36) ; Cape Neddick R. on US 1. Sept. $18,1957$.

Vorth-Isinglass Dr. 3 specimens, N.H-Rockingham Co.: UMMŻ 163199. Strafford Co.: UMMZ 163198.

Merrimack Dr., 99 specimens, N.H.-Hillsboro Co.: UMMZ 1408s3, 141243, 141244, 141245, 163218. Rockingham Co.: UMMZ 141241, 141246, 141247. Mass.-Essex Co.: CU 30434, 30428. Middlesex Co. : CU 30444; BU uncat.
} 
Ipswich Dr., 34 specimens, Mass.-Essex Co. CU $1.5459,30438$

Massachusetts Bay Dr., 59 specimens. Mass.Middlesex Co.: USNM $1188(1,33)$ lectotype. USNM $94686(25,23-36)$. UMMZ 86582 (1. 38) and $\mathrm{MCZ} 24589(4,27-36)$, paratypes of Boleo soma fusiforme: trib. of Charles $R$ at Framing ham. CU 30440 : BU uncat.

Neponset Dr., 22 specimens. Mass.-Norfolk Co. : CU 30533.

North Dr., 9 specimens. Mass.-Norfolk Co. CU 30464

Cape Cod, 386 specimens. Mass. Barnstable Co.: USNM $77860 \quad(1,33)$ holotype and USNM 94683 (36, 27-43) paratypes of Hololepis fusi. formis metac-gadi: Tempies Pd., Osterville: Nov. 2. 1902. CU 30475, 31602, 30487, 30490, 30503, $30772,31173,31254,31165,30494$

Mills River, 85 specimens. Cape Cod, Mass.Barnstable Co. : $0.1 \mathrm{mi}$. W of jet. of Mass. 28 and 149 on Mass. 28. CU 30481, 31162, 31176 31601 , 31170,31538 .

Nantucket Island, Mass.-Nantucket Co, : Gibbs Pd. MCZ 28274 (1. 24) holotype, MCZ 33547 $(8,16-27)$, UMMZ $86601(2,22-25)$ paratypes of Hololepis fusiformis insulae; Aug. 10, 1893. CI 30462 (8. 21-30)

Buzzards Bay Dr. 21 specimens. Mass. Plymouth Co.: CU 30517

Taunton Dr., 35 specimens. Mass.-Bristol Co. CU 30448. Bristol-Norfolk cos.: CU 20582. Plymouth Co.: CU 3076s. 30769 .

Blackstone-Seekonk Dr., 27 specimens. Mass.Worcester Co. : CU 30457.

Pataganset Lake, 13 specimens. Conn.-New London Co.: CU 10182: UMMZ 138515: CU 31006 .

Thames Dr., 31 specimens. Conn.-New London Co.: UCF 136-9, 260. New London-Windham cos. : $\mathrm{UCF} 140-5,260$

Long Island, N.Y.-Suffolk Co.

Lake Ronkonkoma. 114 specimens. NYSM 2441 CU 6527, 29993, 30265, 30279, 30347, 30529 31849 .

Lake Yaphank. 197 specimens: CU 30285, 30352. $31005,31850,31133,31847,32697,33194,34098$ Peconic River, 3 specimens: NYSM 1452, 2410 CU 30258 .

Raritan Bay Dr., 56 specimens. N.J.-Middlesex Co.: CU 30363. Monmouth Co. : CU 30371.

Atlantic Coast of N.J. Dr., 484 specimens. Atlantic Co.: USNM 45142: CU 30390.30398. $31787, \quad 31791, \quad 31797, \quad 32725,32731, \quad 32739$. Burlington Co.: ANSP 20714 , 31123 : CU 20513 , 30382, 30389, 31803, 31794, 31781 $20513, \quad 30382, \quad 30389$.
32744. 40702-8. Ocean Co.: ANSP 55989: CU 27331 $22771, \quad 13163,30374, \quad 30380, \quad 30381 ;$ UMM 114413.

Delaware Dr., 111 specimens. N.J.-Burlington Co.: ANSP 32571-2, 78737: CU 30416. Camden Co. USNM 49085, Mercer Co.: ANSP 32598 ,
$40671-701$. $40711-27$. Pa.-Bucks Co.: Bristol. ANSP $32557-70,32573,40670$.

Atlantic Coast of Delmarva Peninsula, 90 speci mens. Del.-Kent Co.: ANSP 40728-31: CD 32083. Sussex Co. CU 30606 31172 31168, 31171 34718 , 34719. Md.-Worcester Co.: USNM 8.5822 .

Chesapeake Bay Dr., 92 specimens. Del. Sussex Co.: ANSP 40668-9; CU 31169. Md.-Caroline Co. : CU 18621. 18375: uncat Worcester Co. CU 33927, CU 33097, trib. of Pocomoke R., 10.8 mi. S of Snow Hill.

Potomac Dr., 41 specimens. Md.-Charles Co. USNM 100244, 103862, UMMZ 100677. 136032. Charles-Prince Georges Cos.: Mattawoman Cr. May 21, 1933. UMMZ 107090 (1, 31) holotype : UMMZ 107089 (15, 28-32), USNM $117547 \quad(2$. 29-31), USNM $\left.92946^{(4,} 32-34\right)$ paratypes of Hololepis fusiformis atraquae.

James Dr., 15 specimens. Va.-Goochland Co. USNM 107470: UR 136, 262, uncat Plince Ed ward Co.: USNM 197197.

Dismal Swamp-Nansemond Dr.. 15 specimens. Va.-Norfolk Co.: USNM 100307, 100726: CD $30251,30253,30255,24625$.

USNM 107197 .

Chowan Dr., 134 specimens. Va.-Dinwiddie Co. : CU 30252.' Greensville Co. : CU 30254. Sussex Co. : CU 16880. 32090. N.C.-Gates Co.: UMMZ 138483 ; CU 30143.
Roanoke Dr., 99 specimens. Va-Greensville Co. USNM 107554. N.C.-Bertie Co. : CU 29978 Halifax Co.: CU 29977. Martin Co.: CU 29980 Northhampton Co.: CU 17018, 31640.

Trent-Neuse Dr., 232 specimens. N.C.-Craven Co. : UMMZ 138484. Jones Co.: CU 30554. Johnston Co.: USNM 179731. Wilson Co.: USNM 179733 .

Ellis Lake, 62 specimens. N.C.-Craven Co. UMMZ 161986: CU 29983, 29985.

Cape Fear Di.. N.C

Jones Lake, 193 specimens. Bladen Co.: DI uncat. : WMMZ 161968: CU 25304,33107, 33715 UMMZ 161969 (1, 26) holotype of Hololepis ther mophilis oligoporus.

Singletary Lake, 95 specimens, Bladen Co. UMMZ 158771, 161965; CU 35131, 31951. 33720

Salters Lake, 108 specimens. Bladen Co. UMMZ 161973, 161975, 161974; CU 33108 , 3707.15562 .

White Lake, 455 specimens. Bladen Co.: CU $25086,15646,33109,31820,33106,34748$; DU uncat:

Other Cape Fear Dr., 31 specimens. Bladen Co. : CU 33182. New Hanover Co. : Wilmington. ISNM 52066, 52071, 86165, \$6160, paratypes of Hololepis thermophilus. USNM 94687, 49144, 102149. Pender Co.: CU 29987, 33181. Harnett Co. : UMNY 107072 (1, 33) ; Kipling, holotype of Hololepis thermophitus.

Waccamaw Dr., 92 specimens. N.C.-Brunswick Co.: CU 14257. Columbus Co.: UMMZ 161979. $161980,161981,161982,161983$; DU uncat: CU $31023,14302,31938,34370$.

\section{Etheostoma fusiforme barratti (Holbrook )}

Boleosoma Barratti-Holbrook, 1855:5657 (original description)

Hololepis barratti-Putnam, 1863:4 (original description of Hololepis by Agassiz); Cope; 1864:233 (diagnosis of the species of Hololepis); Hubbs and Greene, 1928: 384-385 (Hololepis must replace Copelandellus confirmed by examination of Agassiz's specimens of Hololepis "barratti"); Hubbs and Cannon, 1935:54-62, pl. I, III, (description, range, synonymy); Carr, 1937: 84 (Fla.); Baker, 1939a:36-37 and 1939b: 45 (Reelfoot Lake, Tenn.); Kuhne, 1939: 93; Fowler, 1941:244, fig. 3, not 13 as given, (Suwannee R., Dixie Co., Fla.); Harkness, Pierce, and Lowe, 1941:112 (ecology, Lake Mize, Fla.); Driver, 1942:285 (in key, in part); Meehean, 1942:185 (lakes in Ocala National Forest, Fla.); Goin, 1943: 146 (water hyacinth community, Gainesville, Fla.); Fowler, 1945:40 (distribution table, Pee Dee, Santee, Savannah, Altamaha, St. Johns, Suwannee rivers), 195-196 (synonymy, S. C. records), 252 (Ga. records), 364 (Biloxi, Miss.); McLane, 1948:116117 (in stomach of young Micropterus salmoides from St. Johns R., Fla.); Bailey and Hubbs, 1949:34 (characteristic Floridian species); Dickinson, 1949:26 (two shallow ponds near Gainesville, Fla.); Driver, 1950:298 (in key); McLane, 1950:196-199 
(in stomach of rotenoned Micropterus salmoides, stomach contents of the Hololepis, Buck Pd., Fla.); Reid, 1950:179 (Orange Lake, Fla.); Freeman, 1952a:37 (Congaree R., S. C.); Freeman, 1952b:269 (Barnwell Co., S. C.); Reid, 1952:65 (around floating islands, Orange Lake, Fla.); Freeman and Huish, 1953:39, 44, 91-94, 96102 (in stomachs of Micropterus salmoides, Pomoxis nigromaculatus, Lepisosteus osseus, L. productus); Anderson and Freeman, 1957:106 (Calhoun, Lexington, and Richland cos., Congaree R., S. C.); Randall, 1958:342 (Coastal Plain, Catawba-Wateree R., S. C.).

Poecilichthys quiescens-Jordan, 1884: 478-479 (original description).

Etheostoma quiescens-Woolman, 1892: 294, 297, 299, 300, 302 (description, habitat, Peace R., Hillsboro R., Withlacoochee R., Fla.).

Boleichthys fusiformis-Fowler, 1935:6, 23 (Santee, Cambahee, Edisto, Pee Dee r., Coastal Plain, S. C., in part).

Boleichthys barratti-Schrenkeisen, 1938: 235.

Hololepis barratti barratti-Bailey, 1950: 311-316 (comparison with H. barratti appalachia).

Hololepis barratti appalachia-Bailey, 1950:311-316 (original description).

Etheostoma barratti-Hubbs, 1952:486 (Caddo Lake, Texas); Moore, 1952:11 (Okla.); Bick, Hornuff, and Lambremont, 1953:230 (St. Tammany Par., La., misspelled barrati); Knapp, 1953:128 (range, in part), 126 (key to Texas fishes), fig. 167; Jurgens and Hubbs, 1953:4 (list of Tex. fishes); Bailey, Winn and Smith, 1954:144-145, 161 (Escambia R., Fla. and Ala.); Freeman, 1954:144, 146, 148, 154 (Salkahatchie and Savannah rivers, S. C.); Bailey and Gosline, 1955:20, 44 (number of vertebrae); Carr and Goin, 1955:31, 102 (description, habitat) pl. 30; Eddy, 1957: 220, fig. 547 (range, in part); Hubbs, 1957a:9 (list of Tex. fishes); Hubbs, 1957b:94 (distribution in Tex.); Moore, 1957:198; Briggs, 1958:275 (Fla.); Crittenden, 1958:217 (Bay Co., Fla.); Hubbs, 1958:11 (list of Tex. fishes); Cook, 1959: 35, 200, 203 (Miss.); Patrick, 1961: 257 (Savannah R.).

Etheostoma barratti appalachia-Bailey, Winn and Smith, 1954:144 (two intro- duced centrarchids in the pond from where E. b. appalachia was taken).

Etheostoma fusiforme barratti-Collette, 1961:2051.

Misidentifications-E. fusiforme barratti as Hololepis serrifer-Fowler, 1945:252 (Savannah R., Ga., specimens re-examined); as Villora edwini-Fowler, 1945:251-252 (two series from Piney Woods Lake, Ware Co., Ga., one series re-examined), 293-294 (seven series from Florida, five of which were re-examined).

Types-MCZ 24571 (5 specimens, 37.0$45.8 \mathrm{~mm}$ ), from "Florida." The holotype of Poecilichthys quiescens is USNM 25509, a $35.5 \mathrm{~mm}$ male from a tributary of the Suwanee R. near Nashville, Georgia.

Diagnosis-Distinguished from the other species of the subgenus Hololepis by a combination of the following characters: two anal spines; interorbital pores absent; preoperculomandibular pores usually nine; infraorbital canal incomplete; breast completely scaled. Distinguished from E. fusiforme fusiforme by the following: preopercle more often partially serrate $(36 \%$ of specimens examined); infraorbital pores usually $1+3(70 \%)$; more interorbital scales (1-37, $\overline{\mathrm{x}}: 13.2)$; parietal more completely scaled (usually over $25 \%, \bar{x}: 57$. $5 \%$ ). Maximum size of males $46.2 \mathrm{~mm}$ (USNM 99988, Hillsborough Co., Fla.) and of females $46.6 \mathrm{~mm}$ (CU 35102, Santee River).

Coloration-The range of variation is generally similar to that of $E$. $f$. fusiforme; both forms are extremely variable.

In both sexes there is a tendency toward the development at the base of the caudal of a supramedian spot in addition to the submedian spot present in E. f. fusiforme. When present, the supramedian spot is not as intense as the submedian. The tendency toward the formation of a median band in the first dorsal fin occurs more often in populations of $f$. barratti than in f. fusiforme. This tendency was also noted in the second dorsal and anal fins in some specimens. A male from the Okefenokee Swamp showed the most extreme development of pigmentation (Fig. 10) of any fusiforme males that were examined. The patterns of breeding males and females from four localities are shown (Figs. 9 and 10).

As noted by Collette and Yerger (1962), 

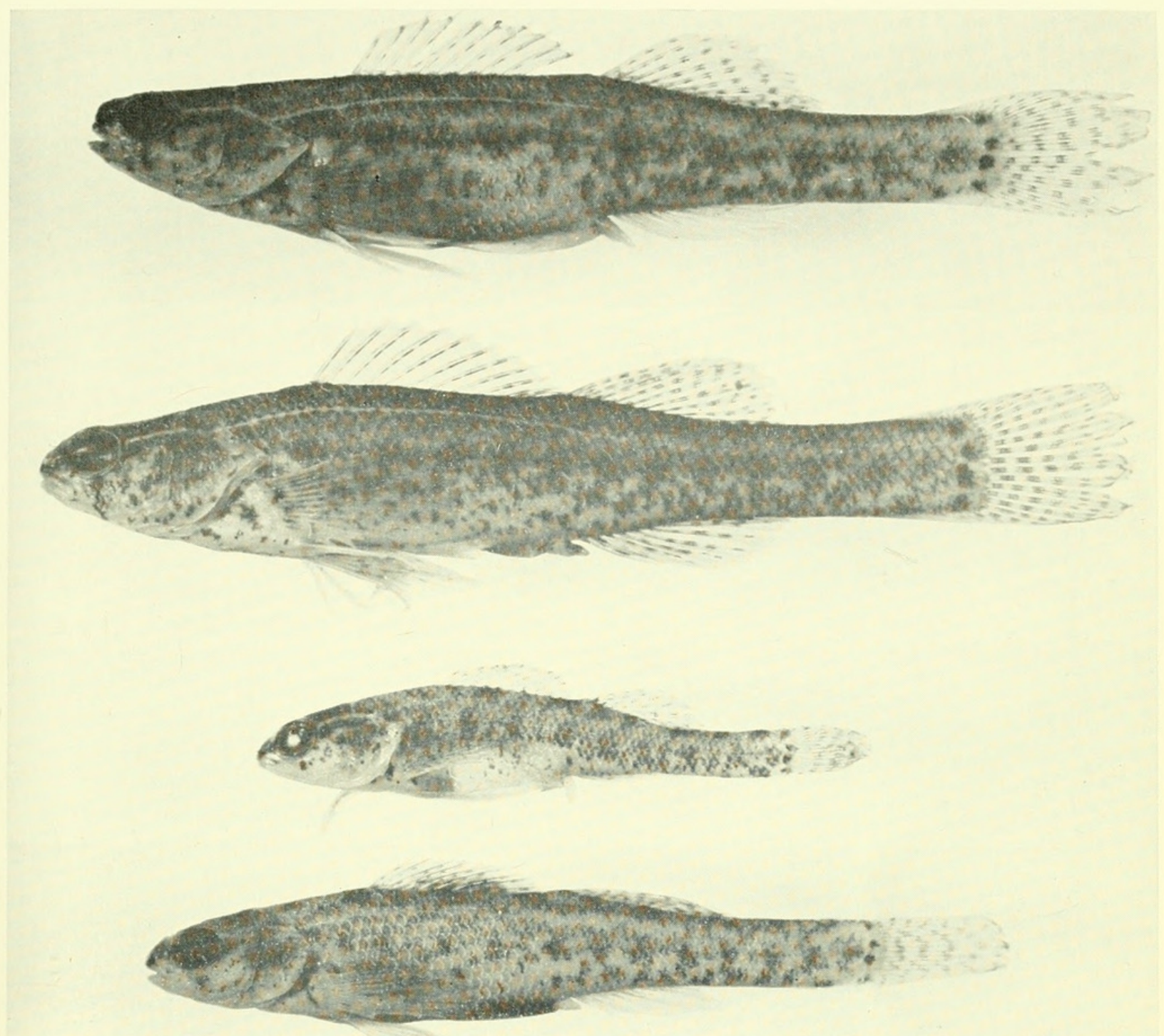

Figure 9. Breeding patterns of female Etheostoma fusiforme barratti. (from top to bottom) CU 29752; 40.2 mm; Ga., Bullock Co., Ogeechee dr.; Feb. 15, 1951. UG 201; $42.3 \mathrm{~mm}$; Ga., Charlton Co., Okefenokee Swamp; Apr. 10, 1951. UG' 205; 24.5 mm; Ga., Irwin Co., Crystal Lake; May 5, 1951. DU uncat; $32.8 \mathrm{~mm}$; N.C., Henderson Co., French Broad dr., date unknown but apparently past height of breeding season. (Photograph by Douglass M. Payne)

the drawing in Fowler (1941: Fig. 13) labeled as Hololepis barratti is reversed with the one labeled as Villora edwini (Fig. 3).

Genital Papilla-The genital papilla of the breeding female is like that in E. fusiforme fusiforme (Fig. 1f) and E. gracile (Fig. 1c).

Breeding Tubercles-Tubercles are present on the anal and pelvic fin rays as in E. fusiforme fusiforme, but are frequently also present on the pelvic and second anal spines. Besides showing a greater development of breeding tubercles than in E. f. fusiforme, the tubercles are present for a longer period of time. In the Ochlockonee popula- tion, tubercles have been found on specimens taken from December 17 through April 13. Tubercles have been found as early as October 27 (Suwannee to Ochlockonee population, FSU 3273) and as late as May 29 (UG 516, Pee Dee population). In these collections not all males have tubercles, and some specimens have them only on the pelvic fins. Specimens with tubercles on both anal and pelvic fins were taken in the period from March 25 to May 29. The spawning period varies between populations but should be within the period that tubercles are developed to their maximum extent. 

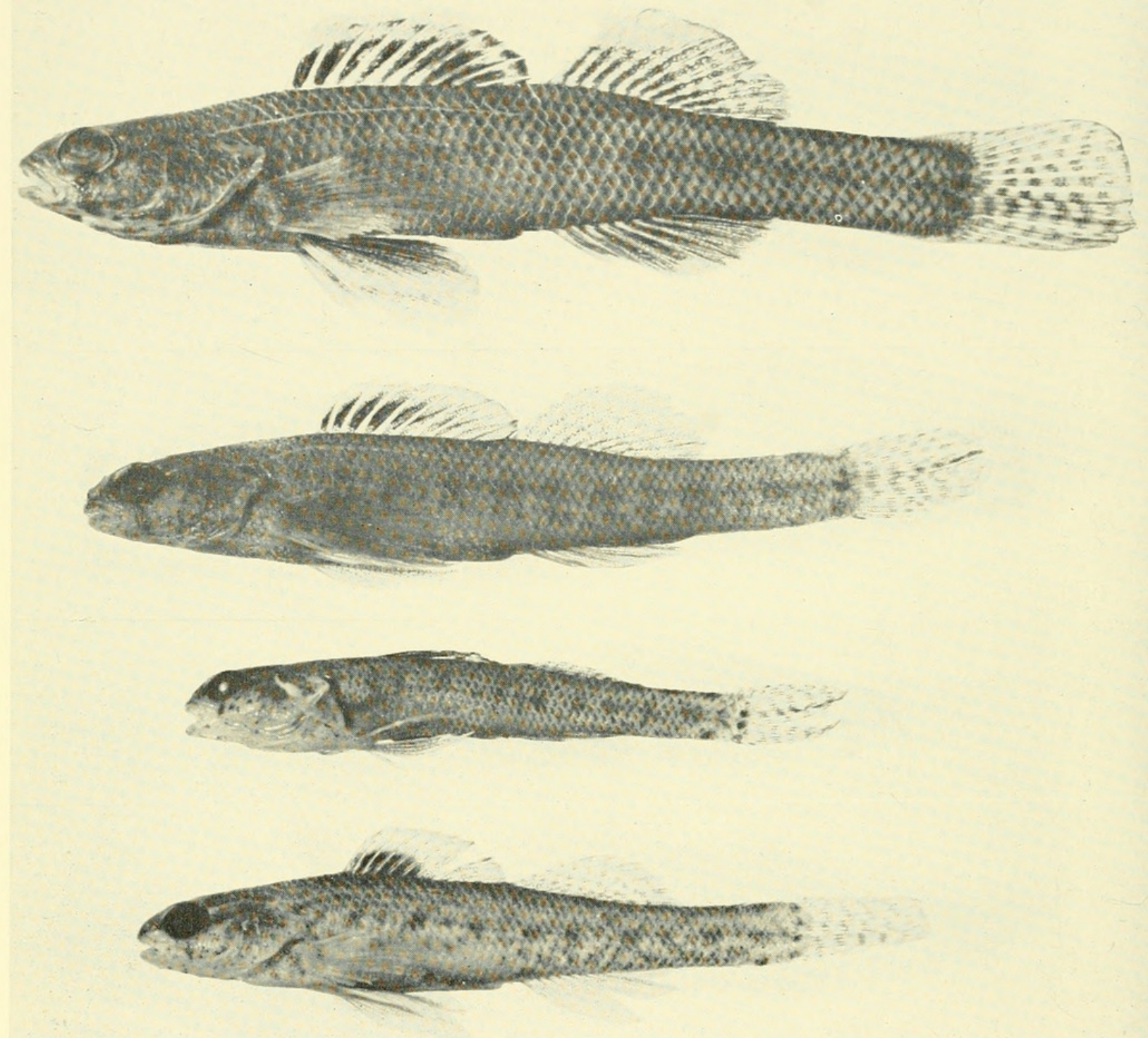

Figure 10. Breeding patterns of male Etheostoma fusiforme barratti. (from top to bottom) UG 201; $46.7 \mathrm{~mm}$; Ga., Charlton Co., Okefenokee Swamp; Apr. 10, 1951. TU 7937; 37.8 mm; Miss., Pearl River Co., Pearl dr.; Mar. 21, 1952. UG 205; $28.1 \mathrm{~mm}$; Ga., Irwin Co., Crystal Lake; May 5, 1951. DU uncat; $32.5 \mathrm{~mm}$; N.C., Henderson Co., French Broad dr., date unknown but apparently past height of breeding season. (Photograph by Douglass M. Payne)

The distribution of breeding tubercles on the pelvic fins of male E. $f$. barratti is essentially the same as in E. gracile (Fig. $1 \mathrm{k}$ ). The distribution on the anal fin of a male f. fusiforme (Fig. 1j) is similar to the distribution in $f$. barratti, except that in the latter the tubercles are more likely to be on the second anal spine.

Development-As in E. fusiforme fusiforme, both the supratemporal canal and the number of pored lateral-line scales change with age. The supratemorpal canal is incomplete in young specimens ( 16.8 to $20.1 \mathrm{~mm}$ ) from Crystal Lake, Georgia (UG
205) (Table 31); the transition period extends from $20.5 \mathrm{~mm}$ to $22.0 \mathrm{~mm}$; and the supratemporal canal is complete in specimens $22.0 \mathrm{~mm}$ and larger. In specimens from the Arlington River, Florida (UF 6945), the juvenile period extends to 21.3 $\mathrm{mm}$, the transition period from 21.5 to $27.4 \mathrm{~mm}$, and the supratemporal canal is complete in specimens larger than $27.4 \mathrm{~mm}$ (Table 31). In a series of collections from Lake Fairview, Florida (ANSP) the juvenile period extends to $19.9 \mathrm{~mm}$ and the transition period is completed by $24.9 \mathrm{~mm}$ (Table 31). 
A $12.6 \mathrm{~mm}$ specimen from the Okeechobee drainage (CU 35069) has scales on the caudal peduncle and extending forward along the lateral line to a point opposite the rear base of the first dorsal fin. A $16.8 \mathrm{~mm}$ specimen in this collection has the body squamation nearly complete but has only four pored lateral-line scales; a $21.6 \mathrm{~mm}$ specimen has 11 pored scales, and the other six specimens (22.8 to $27.2 \mathrm{~mm}$ ) have 15 19 pored lateral-line scales. The incomplete development of pored lateral-line scales in adults from Crystal Lake, Georgia, will be discussed under geographic variation, pored lateral-line scales.

Habitat-Basically the habitat of E. fusiforme barratti is the same as that of the nominate form: swamps, backwaters of streams, sloughs and lakes. Goin (1943) listed E. f. barratti as part of the lower vertebrate fauna associated with water hyacinths (Eichornia crassipes) around Gainesville, Florida. In Orange Lake, Florida, Reid (1950 and 1952) found E. f. barratti both in shallow shore zones and around the edges of floating islands composed of arrowhead (Sagittaria) and pickerel weed (Pontederia) some distance from shore. The characters of a Florida stream containing E. f. barratti are contrasted with those of a stream containing Etheostoma (Villora) edwini under the account of the latter species in Collette and Yerger (1962).

Species Associates-J. R. Bailey (1950) listed Chaenobryttus gulosus, Lepomis $m$. machrochirus, and Lepomis auritus as associates of his Hololepis barratti appalachia. R. M. Bailey, Winn, and Smith (1954) used the presence of Chaenobryttus and $L$. auritus at the type locality of E. $b$. appalachia as an indication that it is merely the product of an introduction.

Woolman (1892), in reporting on the fishes of central Florida, found E. f. barratti in eleven localities. Species commonly found by him with $f$. barratti and the number of times taken were: Gambusia affinis (11); Chaenobryttus gulosus (11); Fundulus chrysotus (8); Jordanella floridae (7); Lepomis machrochirus (7); and Elassoma evergladei (7).

Predators-From lakes Eustis and Harris, Florida, Freeman and Huish (1953) reported E. f. barratti from the stomachs of Micropterus salmoides, Pomoxis nigromacu- latus, Lepisosteus osseus, and L. productus, McLane (1948) reported one E. f. barratti from the stomach of a young $(47-229 \mathrm{~mm})$ Micropterus salmoides floridamus from the St. Johns River. After rotenoning, McLane (1950) also reported 500 E. f. barratti from 62 M. salmoides floridamus stomachs from Buck Pond, Marion County. One had eaten $47 \mathrm{f}$. barratti. He noted that most of the bass may have taken $f$. barratti during the poisoning operation. It seems likely that any larger fish will feed on $E$. f. barratti if they are available.

Habits-McLane (1950) found 82 Chaeborus, 37 Chydoras, 15 Cyclops, 2 Chironomidae, and 2 Amphipoda in nine stomachs of E. f. barratti from Buck Pond, Florida.

Distribution-Found from the Pee Dee River of North and South Carolina south along the Atlantic Coastal Plain below the Fall Line throughout most of peninsular Florida; west along the Gulf Coastal Plain as far as Caddo Lake on the Texas-Louisiana border; and north in the former Mississippi Embayment as far as McCurtain Co., Oklahoma and Reelfoot Lake, Tennessee (Fig. 8). Also known from a few ponds in the vicinity of Asheville, North Carolina, in the French Broad River system, but this population is believed (Bailey, Winn, and Smith, 1954 ) to be the result of an introduction.

Hubbs and Cannon (1935: pl. III) gave the range of E. f. barratti as the Pee Dee River south to the Peace River of Florida and west as far as the Suwannee River drainage of Georgia and Florida. Since then Baker (1939a) reported one specimen from Reelfoot Lake to which I have added another specimen from a collection made in June, 1959. Although Cook (1959) stated that there were no positive records from Mississippi, it has been taken at a number of localities in that state as indicated under the specimens examined.

The presence of E. f. barratti in southeastern McCurtain County, Oklahoma, reflects the influence of the Coastal Plain on the fish fauna of this region, as noted by Recves and Moore (1951) for Lepomis marginatus, L. symmetricus, Fundulus notti dispar, Centrarchus macropterus, and Elassoma zonatum.

Etheostoma f. barratti has been taken from several other localities in the Red River 
system: Caddo Lake on the Texas-Louisiana border (Hubbs, 1952) and from various localities in the northern part of Louisiana. Hubbs (1957b) listed several species that occur in the Red River system east of Lake Texoma but are absent from the Sabine and other drainages to the west such as: Esox niger, Moxostoma erythrurum, Notropis cornutus, N. ortenburgeri, Menidia audens, Stizostedion canadense and E. f. barratti.

A specimen with the locality data of "Spring Creek, Texas," (USNM 118555) must come from west of Caddo Lake and so is the western-most record of E. f. barratti, but due to the large number of places with this name in Texas, the exact locality is unknown.

As Briggs (1958) pointed out, only one of the 11 Florida percid fishes (E. f. barratti) is found in the southern part of the peninsula. He gave the distribution of $E$. $f$. barratti as south to Lake Okeechobee. Woolman (1892) reported $f$, barratti as far south as the Peace River on the Gulf Coast. Recent collections have extended the range farther south into Collier Co. on the west coast (TU 20719) and into Dade Co. near Miami on the east coast (USNM 195862).

Figure 8 shows how clearly the Fall Line delimits the range of E. f. barratti, particularly in the Congaree watershed of South Carolina, where a large number of collections show E. f. barratti (and E. serriferum, Fig. 3) below the Fall Line and E. saludae above it (Fig. 3). It is also of interest to compare Fig. 5 of the distribution of $E$. gracile with Fig. 8. This comparison will show that although there is a large overlap in the total ranges of E. gracile and $E$. $f$. barratti, there are relatively few localities where both have been taken together (Reelfoot Lake, Tenn.; Caddo Lake, Tex.; SE McCurtain Co., Okla.; Ouachita Parish, La.).

Specimens Examined-Complete locality data are given only for those collections which show range extensions or other significant distributional information. Other collections are listed by drainage, state, county, and museum number with the total number examined for each drainage. Complete data for most of the collections can be found in Collette (1960). A total of 2265 specimens from 339 collections was examined.
Pee Dee Dr., 49 specimens, N. C.-Richmond Co.: CU 19570; UG 516. Scotland Co.: UG 457. S. C.-Florence Co.: CU 19189. Georgetown Co.: ANSP 61023-6. Lee Co.: CU 28217.

Santee Dr. $7 \mathrm{~s}$ specimens, S. C.Berkeley Co. USNM 116236. Clarendon Co. CU 26250. Kershaw Co. : CU 35104, 35121, 35123, 35110, 35106 ; USNM 195865, 195866. Lexington Co. : CU 35124, 35122, 35116. Lexington-Calhoun cos. : CU 35102. Richland Co. : CU 35117, 35125, 35112, 35130 , $35113,35127,35115,35105,35129,35103,35108$; USNM 149254 Sumter Co CU 35132 .

Charleston Harbor Dr., 13 specimens, S. C.Charleston Co.: USNM 1143 and 1161. Dorchester Co.: USNM 1185.

Edisto Dr., 16 specimens. S. C.-Bamburg Co. CU 35114, 35101. Colleton Co: ANSP 54788 . Orangeburg Co.: CU 19080, 30622.

Combahee-Broad Dr., 14 specimens. S. C.Barnwell Co.: CU 35118, 35109, 35128. Jasper Co. : CU 32662.

Savannah Dr., 336 specimens, S, C.-Aiken Co. ANSP 73458; UG 247, 270: CU 35107, 35126 24325, 30882; ANSP 78545, 78494: USNM 195864 Allendale Co. : ANSP 73409, 74263, 78875; UG 252 ; UMMZ 167889; CU 30897 ; USNM 162530 , 162531, 162532. Barnwell Co. : CU 35120, 35119 35111, 24396; ANSP 78899 80401: USNM 195863 Jasper Co. UMMZ 155201 Ga-Chat ham Co.: ANSP 79858. Richmond Co.: UMMY 158026: CU 17628, 17209; UG 177; USNM $86194,82624,82625$.

Ogeechee Dr., 49 specimens, Ga.-Candler Co. UG 152, 152B. Bryan Co. : CU 30322 : TU 16454 Bullock Co.: CU 30627, 30625, 30626, 30623 , $30624,29752,29762$. Jenkins Co.: USNM 43457 61567 .

Altamaha-Satilla Dr., 54 specimens. Ga. Appling Co.: CU 29756. Brantley Co.: UG 447 TU 21200. Coffee Co.: BU uncat. Dodge Co. CU 17702. Emmanuel Co.: UMMZ 158045: CU 17686. Irwin Co.: CU 29748; UG 292, 292A Jeff Davis-Montgomery cos. : UG 259. Johnson Co.: TU 14298. Tattnall Co.: CU 29755. Toombs Co. : UMMZ 158062. Washington Co. : CU 29761. St. Marys Dr., 69 specimens. Ga.-Camden Co.: ANSP uncat. Charlton Co.: CU 516, 503 , $522,4043,35136,35137,35135 ;$ UG 200; TU 21309. Fla.-Baker Co. : CU 12615, 21088; TU 21212

St, Johns Dr. 188 specimens. Fla-Brevard Co. : UMMZ 158576. Duval Co. : UF 6945. Flag ler Co.: USNM 125479, 170976. Lake Co.: TU 12519; CU 35140. Seminole Co.: ANSP uncat. CU 24572. Volusia Co.: UF 6940 ; USNM 133270 . Indian River Dr., 1 specimen. Fla.-Brevard Co.: USNM 25343.

St, Cloud, Fla.-Osceola Co. : UMMZ 158641 (39, 24-38) ; canal between Alligator and Lizzie Lakes near St. Cloud; Dec. 28, 1939

Orlando isolates, 204 specimens. Fla.-Orange Co. : USNM 44413, 106941, 133527, 133536 , $133509,133517,133516 ;$ ANSP 4 uncat. coll.

Oklawaha-St. Johns isolates, 90 specimens. Fla. Clay Co. : CU 35067. Marion Co.: UMMZ 110658 , $158125,166544,166601$; UF 6958 ; CU 26277. Osceola Co.: UMMZ 158606. Putnam Co.: CU (3506s.

Lake Okeechobee Dr., 47 specimens. Fla. Hendry Co.: CU 35069. Highlands Co.: OAM uncat. ; CU 24236. Indian River Co. : UF 6948. Osceola Co.: CU 8614, 10235, 12030, 23951;

UMMZ 158555 ; FSU 2496.

Dade Co., Fla.-USNM $195862 \quad(1,19)$; W suburbs of Miami, canal near Milam Dairy' Rd. and Ludlum Rd.; Apr. 7, 1960.

South Florida isolate-Collier Co.; TU 2071! $(54,18-38)$; canal $11.2 \mathrm{mi}$. E. jet. US 41 and Fla 846 , or 21.6 mi. NE of Naples; July 9 , 1959

Charlotte Harbor Dr., Fla.-Charlotte Co. : UMML 4754 (3, 33-39); roadside canal 8.5 mi.

E of Punta Gorda on Fla. 74; Dec. 22, 1957.

Tampa Bay Dr., 46 specimens. Fla.-Hillsborough Co.: UMMZ 139251; CU 12731, 21124 TU 208, 3054, 3772,4626 ; FSU 1846; USNM 100029,$100050 ; 99988,170974,99956,106960$. Pasco Co.: TU 20737. Pinelas Co.: CU 12246. Polk Co. CU 26256.

Withlacoochee-Waccasassa Dr., 101 specimens. Fla.-Citrus Co.: TU 9842. Citrus-Marion cos. : FSU 2131. Lake-Polk cos. : CU 35139. Levy Co. : 
CU 12796, 24550; UF 2903; TU 15672; USNM $106932,106939$.

Newnan Lake Dr., 84 specimens. Fla.-Alachua Co. : UF 6944; UG 9 ; CU 12302, 12846, 16035 ; USNM $88490,93715$.

Suwannee Dr., 68 specimens. Ga.-Berrien Co.: USNM $28509(1,37)$; trib. of Alapaha R. at Nashville; holotype of Poecilichthys quiescens. Irwin Co.: CU 29601; UG 208. Lanier Co. : USNM 94893 ; BU uncat. Lowndes Co.: UG 458. Wilco Co.: CU 17652, 17411. Fla-Bradford Co. U SNM 63779. Columbia Co.: CU 12500; UF 8301 . Dixie Co. : ANSP 69213. Hamilton Co.: UMMZ

Crystal Lake, Ga.-Irwin Co.: UG 205 (26, 17-28) ; Crystal L., $4.5 \mathrm{mi}$. N Irwinville; May 5 , 1951.

Okefenokee Swamp, 88 specimens. Ga.-un known co.: ANSP 55935: USNM 153440. Charlton Co.: CU 8610-3, 257-60, 353-4, 262-5, 129 $320,340,535, \quad 6-7 \quad 9-10,325 ;$ ANSP 79923 ; U 201; USNM 153433. Ware Co.: ANSP 70564 CU 27322; UMMZ 138720.

Fenholloway to St. Marks Dr., 30 specimens. Fla -Lafayette Co : CU 12202, Leon Co. FSU 3273 ; TU 9763. Madison Co.: CU 12484. Taylor Co. : TU 5056. Wakulla Co.: UMMZ 163428 $\mathrm{UF} 1887$

Ochlockonee-New Dr., 122 specimens. Ga. Colquitt Co. : CU 17504. Grady Co.: UG 102, 103; FSU 2887. Thomas Co.: FSU 3970. Fla.Gadsden Co.: UF 6956, 4889; FSU 306, 2167 , 3861 ; TU 22590. Leon Co.: FSU 400, 67, 74 $259, \quad 1300,3609,2091$. Liberty Co. UMMZ 158183 ; FSU 230, 2267, 3755; TU 1116.

Apalachicola Dr., 102 specimens. Ga.-Baker Co. UG 31, 27, 36. Crisp Co: UG 6. Dougherty Co. : UMMZ 164001, 164039 ; BU uncat. Early Co. : UG 25A. Sumter Co. : UMMZ 163989. Taylo Co. : CU 30319. Fla.-Franklin Co.: FSU 2767 Gadsden Co.: UMMZ 166266. Gulf Co. : FSL 1551; TU 20540, 22453. Jackson Co. : FSU 2679 , $2688,2701,2733$

Choctawhatchee to Perdido Bays, 64 specimens. Fla.-Bay Co.: UMMZ 163450. Escambia Co. FSU 2916. Escambia-Santa Rosa cos. : ANS1 72892 , 73028, 79004; UMMZ 165074. Holmes Co.: UMMZ 163501; TU 20406. Okaloosa Co. TU 23694, uncat. Santa Rosa Co. UMVZ 155507 , 165119 ; ANSP 73060 ; TU 10489 . Walton Co. $165119 ;$
TU $311,20855,22730,22775,23154$

Unknown Fla. Dr., 48 specimens.-USNM 92864, 92896, 106941.

Mobile Bay Dr., Ala.-Mobile Co. : TU 6257 (4, 30-44) ; Hall's Mill Cr, at Naveo, trib. of Do R., Feb. 11-13, 1938. Washington Co.: UMMZ $163599(4,33-38)$; Bilbo Cr., on US 43 near McIntosh, T3N, R1E, Sec. 7; Apr. 12, 1941.

Mississippi Sound Dr., Miss.-Hancock Co.: TL $7663(6,32-42)$; Bayou Phillip, trib. to Jordan k. 2.5 mi. E of Waveland on rt. 90 ; Mar. 9, 1953 Harrison Co.: ANSP $55746(1,36) ; 3$ mi. N of Biloxi in cypress cr.; Mar. 15, 1932. Stone Co,: USNM $195873(1,36)$ : Red Cr. near US 49 , near Wiggins; May $13,1933$.

Pearl R.-Lake Pontchartrain Dr., 41 specimens. Miss.-Pearl River Co.: Hobolochitto Cr., 0.9 mi. N of Picayune on US 11: TU 7937, 14103 $5112,7670,16773$; UMMZ 166128; CU 31890. La.-St. Tammany Par. : CU 32247 (1, 40); mi. W of Slidell. TU $379(1,34)$; slough at second bridge $W$ of Pearl $R$. on Hickory Rd. TU $5755(1,38)$ and TU $835(1,35)$; Talisheek Cr., 0.3 mi. N of Talisheek. TU $8159(1,40)$ canal along W Pearl R., $13 \mathrm{mi}$. $\mathrm{N}$ of the town of Pearl River. TU $15144(2,34-37)$, TU 17369 $(6,34-40)$, and TU 17413 (4, 35-38); Talisheek Cr. at Talisheek on La. 41. Tangipahoa Par. TU $3574(1,40)$; Selser Cr., $3.3 \mathrm{mi}$. E of Hammond on rt. 7 .

Yazoo Dr., Miss, - Warren Co. USNM 12909 $(1,38)$ : Yazoo R. at bridge on US 61 near Vicksburg; May 1933. Yazoo Co.: USNM 170977 $(1,36)$; Little and Big Kilby Lakes, Yazoo City June $2,1933$.

Reelfoot Lake, Tenn.-Obion Co. : UMMZ $105397(1,39)$; stagnant basin at $\mathrm{N}$ end of lake; July 26, 1937. CU 33345 (1, 20): X end of lake by Oak Log Lodge near the Reelfoot Biological Station; June 27, 1959.

Red River Dr., La.-Caddo Par.: USNM $172636(9,21-26)$; Black Bayou L., 0.5 mi. above dam on E side of lake, sec. 23, T22N, R15W; July 24, 1956. Ouachita Par. : UMMZ uncat. $(2,30-40)$; Cheniere Cr. below dam of Cheniere L., Sec. 17 and 20, T17N, R3E ; June 6, 1956. Union Par. USNM 172708 (8, 21-27): Bayou de l'outre at La, 2 Hattick Lake, sec 20 , T2oN, R3E; June 18, 1955. Okla.-Mccurtain Co. OAM 3078 (8, 25-31); Aug. 20, 1948; and CU 33747 (8, 20-25); June 24, 1959; cypress swamp $3 \mathrm{mi}$. S of Eagletown on dirt road. Tex.-Harri son Co.: OAM 4732 $(9,29-39) ; 3.5 \mathrm{mi}$. NE of Kernack on Caddo Lake; Mar. 24, 1951.

Unknown Texas Dr.-USNM $118555(1,36)$ Spring Cr.; Apr. 23, 1940.

French Broad Lr., N.C.-Buncombe Co.: pond $\mathrm{S}$ of mouth of Bent Cr., $300 \mathrm{ft}$. W of the French Broad R., $7 \mathrm{mi}$. SSW of Asheville. UMMZ 156224 $(1,37)$ holotype, UMMZ $156225 \quad(49,17-43)$ paratypes, July 14, 1947 , and CU 18444 (3, 30-40) June 7,1949 , paratypes of Hololepis barrati appalachia. Henderson Co.: DU uncat. $(12,28$ 38) ; Cane Cr. oxbow, $1 \mathrm{mi}$. SW of Fletcher, 1 mi. above mouth of Cane Cr. into French Broad R. ; 1952 .

\section{Geographic Variation in Etheostoma fusiforme}

Variation in the characters examined for the two valid subspecies (E. fusiforme fusiforme and E. fusiforme barratti) will be discussed in this section (Tables 18-31). Nine names presently apply to segments of this species. From north to south they are: fusiforme fusiforme (Girard) from southern Maine through Massachusetts, exclusive of Cape Cod; f. metaegadi (Hubbs and Cannon) from Cape Cod; $f$. insulae (Hubbs and Cannon) from Nantucket Island; f. erochroum (Cope) from New Jersey and the Delmarva peninsula; $f$. atraquae (Hubbs and Cannon) from the Potomac River; thermophilum thermophilum (Hubbs and Cannon) from the Neuse, Cape Fear, and Waccamaw rivers, and White Lake; t. oligoporum (Bailey and Frey) from the dark-stained North Carolina Bay Lakes (Salters, Jones, Singletary) in the Cape Fear drainage; barratti barratti (Holbrook) from the Pee Dee River south through most of penisular Florida, west to the Red River in Texas and Oklahoma, and north in the Mississippi Embayment as far as Reelfoot Lake, Tenn.; and b. appalachia (Bailey) from the French Broad River, near Asheville, N.C. The validity of these nominal forms will be discussed below.

Total Lateral-line scales (Table 18): Hubbs and Cannon (1935:83) gave the number of total lateral-line scales of their Hololepis fusiformis insulae from Nantucket as "somewhat fewer than in typical fusiformis and much fewer than in metaegadi." This was true on the basis of the one Cape Cod collection on which metaegadi was based and a few more recent 
collections. However, at one Cape Cod locality, Mills River, counts are intermediate between insulae and metaegadi ( $\overline{\mathrm{x}}$ : Nantucket-44.71, Mills River-48.84, and the rest of Cape Cod-52.34). There is also a reduced mean number of total lateralline scales in some other scattered populations: the Weweantic River just to the west of Cape Cod ( $\overline{\mathrm{x}}: 48.35)$; the coastal streams south of Raritan Bay, New Jersey (46.58); the James River of Virginia (46.57); and Crystal Lake, Georgia (46.04).

Several populations have more total lateral-line scales than f. metaegadi: Lake Ronkonkoma, N.Y. ( $\bar{x}: 55.71)$; Pataganset Lake, Conn. (54.62); Lake Yaphank, N.Y. (54.13); Pearl-Pontchartrain, La. (55.10); Red River (55.68).

Pored lateral-line scales (Table 19): The major difficulty with regard to this character is the great amount of variation present (0-37 scales). This is particularly true in a number of natural lakes in North Carolina, known as the Bay Lakes.

Although the Carolina Bays have long been a subject of geological investigations to determine their mode of origin, relatively little is known about the biology of the few lakes that remain in the Bays. Fowler (1942) and Hubbs and Raney (1946) described four endemic species of fishes from Lake Waccamaw, the largest of the southern North Carolina natural lakes. Later (Frey, 1951), Notropis waccamanus Fowler was reduced to a synonym of $N$. petersoni Fowler. Frey (1948a, 1948b), Hueske (1948), and Louder (1958, 1959) published a series of popular papers about the lakes and their fauna.

Frey also published a series of scientific papers (1949, 1951) and Bailey and Frey (1951) recognized two subspecies of Hololepis thermopbilum from the Bay Lakes. They named the form in the dark stained lakes thermophilum oligoporum and considered the nominate form to be present in the clearer lakes (White, Ellis, and Waccamaw) as well as in the Cape Fear and Neuse rivers. Bailey and Frey (1951) were aware of the biogeographic difficulties in this allocation of subspecies: lakes White, Waccamaw and Ellis each belong to a separate major Atlantic drainage while the dark lakes (Jones, Salters, Singletary) along with White, are found in the Cape Fear system. Bailey and Frey discussed the pos- sibility of polyphyletic origin of $t$. oligoporum. I believe that taxonomic recognition should be withheld when polyphyletic origin of a subspecies is suspected.

A special search was made for a reasonable explanation for the presence of the different forms in the dark and light Bay Lakes. The explanations proposed are based on an intensive study of the Bay Lakes and their fishes. The best differentiating character lies in the number of pored lateral-line scales, which is considerably reduced in the dark lakes. Frey (1951) noted a similar situation, with the Perca flavescens and Chaenobryttus gulosus from the darker lakes having fewer total lateralline scales, but considered these to be cases of ecotypic variation. Bailey and Frey (1951) rejected the possibility that their thermophilum oligoporum was an ecotypic variation.

The correlation between water color and number of lateral-line scales might be due, not to color per se, but to productivity. Therefore, the productivities of the lakes were compared. Productivity is characterized in many different ways so several methods of estimation were utilized, both physical-chemical and biological.

Increased productivity is frequently correlated with increased carbonate content. Carlander (1955) showed a positive correlation between fish crop and methyl orange alkalinity in trout lakes, warm water lakes, and reservoirs. Moyle (1949) showed a positive correlation between yield of pikeperch and total alkalinity. Frey (1949) presented a summary table of physical and chemical characteristics of the Bay Lakes. He gave the alkalinity in $\mathrm{ml}$. $\mathrm{N} / 44 \mathrm{H}_{2} \mathrm{SO}_{4}$ because there is some free sulphuric acid present in some of the lakes. Thus the alkalinity cannot be stated in the usual manner (parts per million of methyl orange alkalinity). However, it is apparent that the lakes fall into two categories (Table 28); a low alkalinity group, the Bladen County Lakes (Black, Jones, Salters, Singletary, White) and a high alkalinity lake (Waccamaw). This high alkalinity is apparently due to the solution of lime and other minerals from the outcrops of the calcareous Duplin formation, and of the older Cretaceous formation along the northeast shore (Clark, et al., 1922).

The $\mathrm{pH}$ of lakes is also correlated with 
productivity. Smith (1952, 1953b) noted the low productivity of New Jersey waters with a pH below 6.0. Renlund (1950) noted the absence of a number of plants (especially species of Potamogeton) from the acid lakes of southern New Jersey. Table 28 shows the $\mathrm{pH}$ as taken from Frey (1949). Again there are two distinct groups; the Bladen County Lakes on the one hand and the more alkaline Waccamaw on the other.

Shoreline development is also correlated with productivity (Welch, 1952) since increased irregularity of shoreline results in greater contact of water with land, increased area of protected bays, greater diversification of bottom and margin conditions, increased areas of shallow water for growth of rooted vegetation, and increased opportunity for close super-position of the photosynthetic zone upon the decomposition zone. The last two factors are of no importance here because all the lakes are so shallow. These lakes are all oval with few irregularities, so the figure for shore line development (Table 28) is quite close to 1 , the value for a perfect circle. Singletary Lake has an artificial dredged channel, 160 yards long, in the outlet creek and so has the highest value (1.17).

Another factor that limits productivity is the amount of light energy that reaches the phytoplankton; that reaching a certain depth in a lake is due to differences in transparency which in turn varies with three factors: color of the water; amount of organic and inorganic material in the water; and the amount of plankton present (Ruttner, 1953). The first two factors are of importance in the Bay Lakes. Frey (1951) gave the actual color of the water in parts per million of potassium chloroplatinate (Table 28). However, the scattering of the radiation by suspended materials is just as important as the absorptive function of the coloring material in these lakes. Singletary, Black, and Salters lakes have larger quantities of non-living organic materials than do the other lakes. Light penetration, as measured with the Secchi disc, takes into consideration both of these factors. Based on Frey's mean Secchi disc readings, the lakes fall into three groups (Table 28): low light penetration (Black, Jones, Salters, Singletary); moderate penetration (Waccamaw); and high penetration (White).
Table 29 ranks the physical-chemical indices of productivity from 1 to 6 and the totals of these rankings give a physicalchemical index of productivity by means of which the lakes may be arranged in order of increasing productivity namely: Black, Jones, Salters, Singletary, White, Waccamaw.

Certain biological characteristics can be used to measure productivity. One of these is the relative amount of rooted aquatic vegetation. Data from Frey (1948a, 1948b, 1949), Louder (personal communication), and personal observation classify the lakes as follows: 1. no rooted aquatics (Black, Jones, Salters); 2. small amount, especially in the artificial channel (Singletary); 3. moderate amounts (White and Waccamaw). In addition to being a measure of productivity, the amount of aquatic plants present has a direct effect on productivity. One of the reasons that the darker lakes are so unproductive is that there are few aquatics present to provide food, cover, and spawning sites for fishes and other animals. The lack of abundant rooted aquatic vegetation is caused in part by the dark water which prevents photosynthesis at other than very shallow depths.

The number of species of fish (or other animals) present may also be used as an indication of relative productivity. Frey (1951) listed the species of fishes collected during the 1947 survey as follows: Black-8; Salters-11; Jones-12; Singletary-13; White-17; and Waccamaw-25. Since then my collections and those made by Darrell E. Louder (1959 and personal communication) have added to the number of species taken in all of the lakes (Table 30). Frey (1951) pointed out that there is a group of 11 species in almost all of the lakes (Table 30) with Etheostoma f. fusiforme and Esox niger lacking only in Black Lake. Apbredoderus sayanus may now be added to this list and is absent only from Jones Lake. In the various lakes, additional species are found correlated with increased productivity until Waccamaw is reached, which has all but one of the species present in the other lakes. Here Fundulus notti lineolatus is replaced by the endemic $F$. waccamensis. Frey noted that probably none of the species of Lepomis is native to the Bladen County lakes. Introductions have of course been attempted, from which subsequent re- 

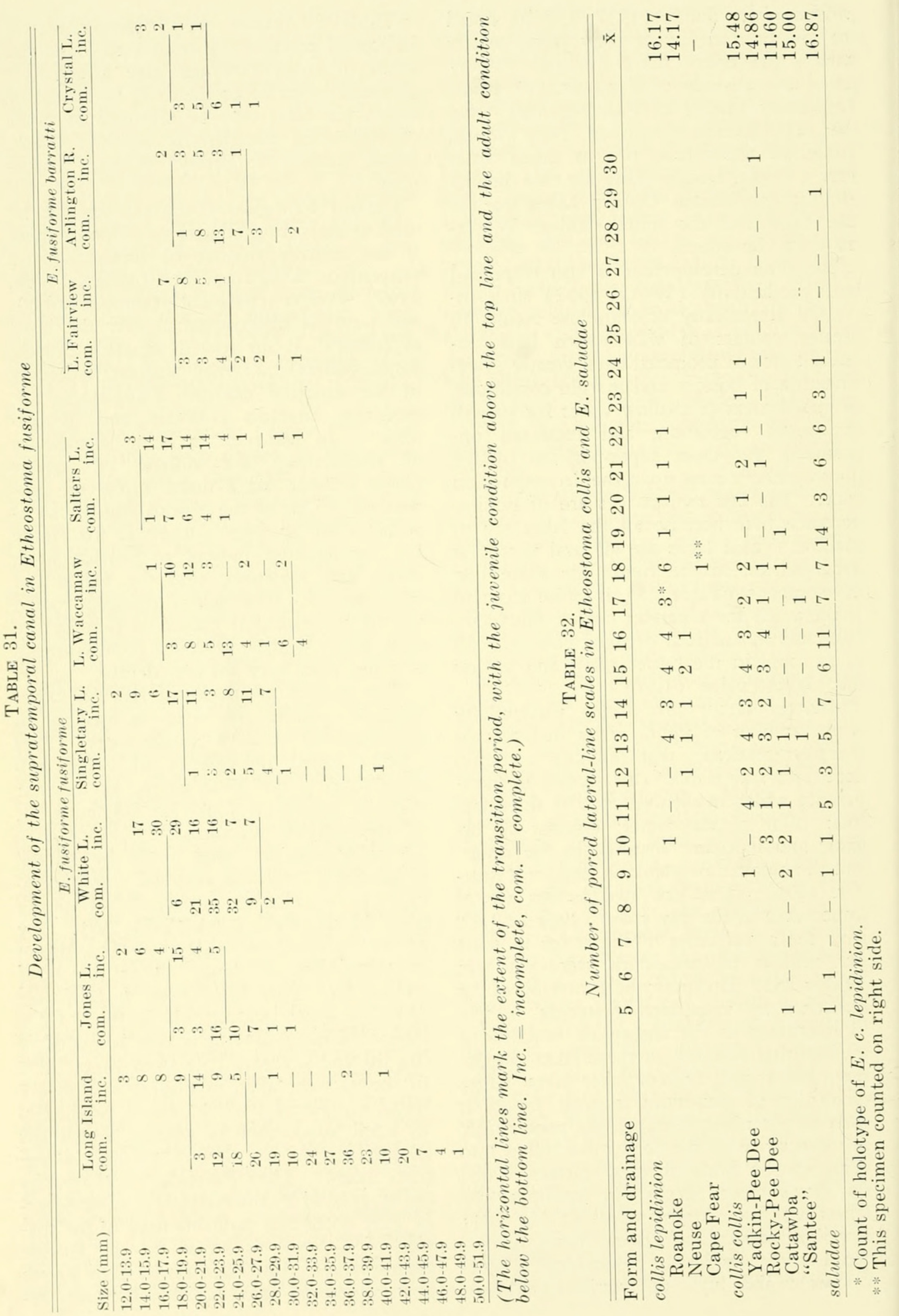
captures have been made only in Singletary and White lakes. Based upon present data, the lakes may be ranked with the number of fish species present as the criterion as follows: Black; Jones; Salters; Singletary; White; Waccamaw.

Meager data for a third type of biological estimate of productivity are available. In the course of fishery investigations upon the Bay Lakes made by D. E. Louder, two shore rotenone collections of a half acre each were made during the summers of 1957, 1958 and 1959 in each of the lakes (1959 collections omitted in Black Lake). The mean pounds of fish per acre from these samples is included in Table 28. These values are used with some hesitation for several reasons. Two samples per lake, per year, especially in a lake as large as Waccamaw, can not adequately represent the productivity of the lake. Secondly, the variations between the pairs of collections from Waccamaw are so great as to make the value of these quantities dubious. Nevertheless, ranking the lakes by this method gives the following order: Black; Jones; Singletary; Salters; and Waccamaw and White.

If the three biological characters are ranked in the same manner as the physicalchemical factors, the lakes fall into the same order (Table 29). Plotting the mean number of pored lateral-line scales alongside of the physical-chemical and biological indices of productivity (Table 29) shows them to be correlated. White and Waccamaw appear to be reversed, but the difference between these two (as well as between Jones and Salters) is not of great significance because differences of this magnitude or greater occur between most isolated populations. What is the significance of this correlation? Is this correlation caused by some effect of the environment upon these fishes?

To answer these questions the development of the pored lateral-line scales was studied (see development of E. f. fusiforme). The development of pored lateralline scales in the Long Island population (Fig. 11) and in White Lake (Fig. 12) is similar except that in White Lake there are a few adults 23 and $24 \mathrm{~mm}$ long that have retained the juvenile condition of a reduced number of pored scales.

When the data for Jones Lake are ex-

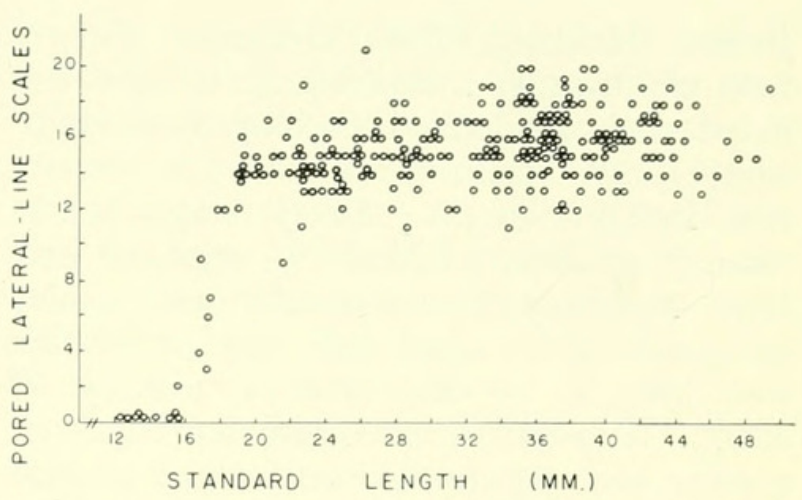

Figure 11. Change in the number of pored lateral-line scales witi size in Etheostoma fusiforme fusiforme from two ponds on Long Island, New York.

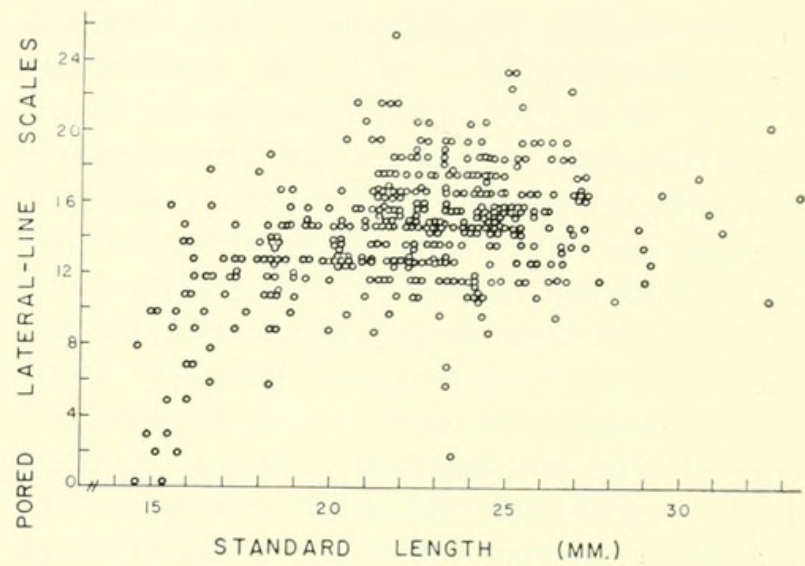

Figure 12. Change in the number of pored lateral-line scales with size in Etheostoma fusiforme fusiforme from White Lake, North Carolina.

amined (Fig. 13) a different picture is revealed. The no-pored condition is present until about $16 \mathrm{~mm}$ as in the two preceding cases, but here the transition period is never completed. Some of the largest specimens examined lacked pored lateralline scales. It is apparent that here too the number of pored scales does not change after maturity; the whole range of variation has merely been shifted to lower values. Since this population retains into maturity the juvenile, no-pored condition, or at least a reduced number of pored scales, it can be considered a case of neoteny. In other words, there is a relative retardation in the rate of development of the body as compared with the reproductive organs, so that the body does not go through as many steps in development in the ontogeny of the descendants as it did in that of the ancestor (de Beer, 1951).

What has caused neoteny in the dark Bay Lakes populations of Etheostoma f. fusi- 
forme? Hubbs (1926) discussed the results of changes in developmental rate and noted that accelerated development might lead to the retention of juvenile characters. In the dark Bay Lakes, under conditions of reduced productivity, selection may have acted to favor populations capable of spawning at a younger age or smaller size because of the relative scarcity of food. If populations could reproduce at smaller sizes they would be favored because of the food economy effected. Thus, selection could gradually reduce the size of the E. fusiforme in the dark lakes and result in a reduced number of pored lateral-line scales. Hubbs (1926) noted that degeneration resulting from a change in developmental rate does not primarily or necessarily involve any genetic loss, but involves physiological adaptations which preclude the completion of certain ontogenetic processes. Evidence is not yet available to determine whether or not the reduced number of pored scales in the dark Bay Lakes is genetically controlled or is a direct result of the environment. However, there is no significant difference between the number of pored lateral-line scales between the 1947, 1958, and 1959 year classes (see section IV) indicating that direct environmental control is unlikely. Linder (1958: 205-206) noted that E. spectabile and E. spectabile $\mathrm{x}$ radiosum hybrids, raised from eggs laid in the laboratory failed to develop any pored lateral-line scales. It would be interesting to raise $E$. fusiforme from the light and dark Bay Lakes for several generations to discover if there is genetic control for this neotenic character.

There is still more evidence for the neoteny theory. Examination of the variation in the number of pored lateral-line scales in E. fusiforme barratti (Table 19) shows that a few populations of this subspecies also have a reduced number of pored lateralline scales. The over-all mean for $f$. barratti pored lateral-line scales is 20.65 , while the mean of a population of $f$. barratti from Crystal Lake, Ga. is only 6.06. This lake is surrounded by the Suwannee River drainage although it lacks both inlet and outlet. The mean number of pored lateral-line scales in the Suwannee population is 22.41. Thus, in the Suwannee drainage, there is an even greater difference than between the dark and light Bay Lakes.
Crystal Lake, Ga. is not a dark stained lake as are the unproductive Bay Lakes. The only apparent similarity between these lakes is their poor productivity. Donald C. Scott (personal communication) described Crystal Lake as "one of a number of sink hole lakes in Georgia which is filled with beautiful white sand and crystal clear water; the latter would double well for the distilled product. Crystal Lake has no inlet or outlet, its water obviously is rainwater that has percolated through nothing more than clean sand. The water of the lake has no contact with the underlying limestone responsible for the basin. The carbonate content is only about 15 p.p.m., vegetation is sparse, plankton likewise." Two collections (UG 205, 205a) were made on May 5, 1951, and April 26, 1952, and only 13 species of fishes were taken. Interestingly (Table 30 ) the first six species listed are part of the core of 11 species present in the Bay Lakes. The next three were found in at least one dark and one light lake. Notemigonus was taken only in Lake Waccamaw. Only the last three species were not taken in the Bay Lakes. If Crystal Lake is placed in the ranked Bay Lakes series it ranks at about the same level as Salters Lake. (This results from ranking the alkalinity as 1 , the aquatic vegetation as 3 , the light penetration as 6 , and the number of species as 2, for a total of 12 while Salters equals 11.5.) Because Crystal Lake is clear, water color is eliminated as a sole cause of the difference in number of pored lateral-line scales between the dark and light Bay Lakes. However, color is important because of its great effect in reducing productivity by limiting photosynthesis. This is supported by the fact that the E. f. fusiforme from Ellis Lake, North Carolina, have a normally high number of pored lateral-line scales ( $\bar{x}: 13.31$ vs. an over-all mean for E. f. fusiforme of 13.96). This, as Bailey and Frey (1951:202) noted, is a dark, shallow lake with a low $\mathrm{pH}$ and low concentration of chemically active substances. They also pointed out (p. 192) that "Ellis Lake has large fish populations, and might be even more productive per unit area (or volume) than Waccamaw." Once again it is productivity that is correlated with the number of pored lateralline scales.

Several other populations of E, f. barratti 
had unusually low numbers of pored lateralline scales (Table 19). One of these is from a canal between Alligator and Lizzie lakes near St. Cloud, Osceola Co., Florida (UMMZ 158641). These two lakes are connected, by canal only, with the St. Johns River system. The mean of a sample from the St. Cloud population is 13.42, while that of the St. Johns population is 22.68. Collections are available from a number of small isolated lakes in and around Orlando, Florida. These also have a low mean number of pored lateral-line scales ( $\bar{x}: 16.76)$. However, in this case some lakes seem to have normal populations, others intermediate forms. There are collections from the Lake Okeechobee drainage which also have a reduced number of pored lateral-line scales $(\overline{\mathrm{x}}: 17.33)$. Here the range is 5 to 30 in adult specimens. There is a temptation to cite these cases as additional corroboration of the neoteny theory, but unfortunately no information was available on the productivity of these lakes.

If the low number of pored scales in the dark Bay Lakes has arisen independently through neoteny in each of these lakes, then the populations in the Cape Fear River, which is presumably more productive, should have a higher count similar to the specimens from productive White Lake. I tried to collect specimens in Turnbull Creek, which receives drainage from both Jones and White lakes. The localities seined were moderately fast streams for the Coastal Plain and no E. f. fusiforme were collected. However, specimens were available from various localities in the Cape Fear River. The majority of these are paratypes of Hubbs and Cannon's "thermophilum" taken from the region around Wilmington, N.C. These specimens plus several smali Cornell collections (Table 19) show a count ( $\bar{x}: 14.07)$ which is closer to that of the White Lake population than that of the dark Bay Lakes populations. Probably the river was originally populated by a form with a normally high number of pored scales. Some individuals were able to make their way into each of the Bay Lakes (except Black Lake?) where populations built up quite rapidly. Then, in each of the dark lakes, the scarcity of food caused selection to favor the development of neotenic populations.

Dorsal Spines (Table 20): The range is eight to thirteen, with the mode usually ten. Six E. f. fusiforme populations have a mode of nine and one (Nantucket) has a mode of eight spines. Eight dorsal spines was the primary character of which Hubbs and Cannon (1935:83) based their $f$. insulae. The Nantucket population is quite different from the Cape Cod and other Massachusetts populations in this regard. However, the Weweantic River, which is just west of Cape Cod, has a population with a mode of nine, bridging the gap between nominal metaegadi and insulae. The other five populations of $E$. $f$. fusiforme with a modal number of nine are: Raritan, N.J.; Nansemond, Va.; and the three dark N.C. Bay Lakes (Singletary, Salters, Jones). This seems to be a separate system of variation, not connected with neoteny, because both the neotenic and normal populations of E. f. barratti have modes of ten dorsal spines (except for the Red River population, which has a mode of eleven).

Dorsal Rays (Table 21): There is a range of eight to thirteen and the mode is either ten or eleven. The variation is slightly different from that in other characters. Populations of E. $f$. fusiforme seem to alternate geographically between modes of ten and eleven. All E. f. barratti populations from the Savannah southward have a mode of eleven. The Pee Dee, Edisto, and Combahee-Broad populations have modes of ten like adjacent E. f. fusiforme, indicating that the break between the Waccamaw and Pee Dee rivers is not as complete as in other characters.

Scale rows above the lateral line (Table 22): The range is two to four, with one specimen from coastal Maryland having

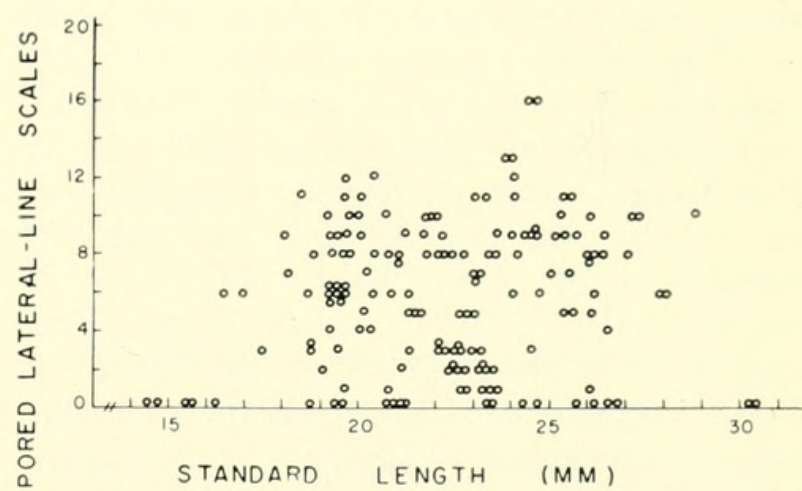

Figure 13. Change in the number of pored lateral-line scales with size in Etheostoma fusiforme fusiforme from Jones Lake, North Carolina. 
five scales. The mode of most populations of both subspecies is three. The only populations of E. f. fusiforme with a mode of two are lakes Ellis, Salters, Jones, White, and Waccamaw. This was one of the characters used by Hubbs and Cannon (1935) in distinguishing thermophilum. However, the other North Carolina Bay Lake (Singletary) has a population with the normal mode of three scales. The reason for this is as yet unknown; the more productive Bay Lakes (White, Ellis, and Waccamaw) all have a reduced number.

Several populations of E. $f$. barratti also have a mode of two: St. Cloud, Fla.; Orlando, Fla.; and Crystal Lake, Ga. This is of interest because these populations are neotenic with regard to pored lateral-line scales. The reduction in number of pored lateral-line scales is correlated with the reduction in the number of scales below the lateral line. Perhaps the low productivity in these lakes has led to a reduction in several different characters.

Scale rows below the lateral line (Table 22): The range in E. fusiforme is six to twelve scales. The mode in the majority of populations is either eight or nine scales. There are three populations of E. f. fusiforme and two of E. f. barratti that have a mode of only seven: Ellis, Salters, other Cape Fear, Crystal Lake, Ga., and Orlando, Fla. The other four North Carolina Bay Lakes populations (Singletary, Jones, White, and Waccamaw) all have a more typical mode of eight. St. Cloud, Fla., Lake Okeechobee, Fla., and the Santee River, S.C., are the only populations of $f$. barratti with modes of eight; the first two are neotenic with regard to pored lateral-line scales. This character shows the same trend as the scales above the lateral line. If these two numbers are added together (Table 22) most populations have a total greater than 10.5 in E. f. fusiforme and greater than 11.2 in E. f. barratti. The populations with the lowest total number are neotenic and partially neotenic ones: Ellis Lake, N.C. (9.23); Salters Lake (9.65); other Cape Fear (9.65); Waccamaw (9.85); and in E. $f$. barratti, St. Cloud (10.28); Orlando (9.48); Lake Okeechobee (10.55); and Crystal Lake (9.36).

Anal Spines (Table 42): There is no significant variation in anal spines; almost all E. fusiforme have two. Seventeen speci- mens of E. f. fusiforme and eight of E. f. barratti had only one spine while two specimens of E. f. barratti had three spines.

Anal rays (Table 23): The range in this character is five to ten with the mode at either seven or eight, except for the Newnan Lake, Fla. population which has a mode of nine. Bailey (1950) gave a modal number of eight anal rays for his Hololepis barratti appalachia versus a modal value of seven for other barratti populations. However, as Table 23 shows this is hardly the basis for describing a new subspecies.

Pectoral Rays (Table 23): The range is 12 to 15 with the majority of specimens of both subspecies having 13. The Crystal Lake, Ga. population stands out with a range of 14 to 15 and a mode of 15 . Perhaps this difference is negatively correlated with the reduced number of pored lateralline scales present in this population; however, the other neotenic populations typically have the usual mode (13).

Branchiostegal Rays (Table 44): The range of this character was from five to seven with the majority of specimens having six rays. The few Cape Cod specimens examined showed a slight tendency to have more specimens with five rays. There was not sufficient variation in this character to necessitate presenting the frequency distributions by river systems, so summaries of both subspecies are presented in comparison with the other forms studied.

Interorbital Pores (Table 45): All the E. f. fusiforme examined lacked interorbital pores, but a few specimens of E. f. barratti had one or two pores present.

Infraorbital pores (Table 24): There were 11 different combinations of the pores in this

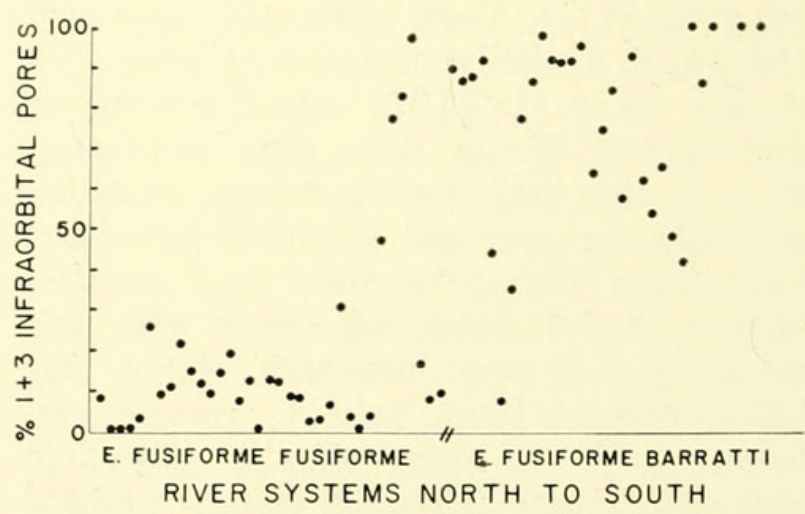

Figure 14. Percent of individuals with $1+3$ infraorbital pores by river systems from north to south in Etheostoma fusiforme. 
canal. They have been arranged across the table in the order of increasing numbers of pores in both segments of the canal. Since there were only two major categories $(1+3$ and $2+3)$, the infrequent counts were added to the more similar of the two frequent counts and the percentage of $1+$ 3 individuals in each population was computed.

The number of infraorbital pores was used by Hubbs and Cannon (1935:30) to differentiate fusiforme and thermophilum $(2+3)$ from barratti $(1+3)$. The present study confirms this with $80 \%$ of $E$. fusiforme fusiforme having $2+3$ pores and $70 \%$ of E. fusiforme barratti having $1+3$ pores (Table 24).

Bailey and Frey (1951) used the number of infraorbital pores to distinguish their thermophilum oligoporum $(1+3)$ in the dark North Carolina Bay Lakes from thermophilum thermophilum $(2+3)$ in the lighter Bay Lakes. The present study confirms these differences: the dark Bay Lakes have a high percent of individuals with $1+3$ pores (Singletary-77\%, Salters- $83 \%$, Jones-97\%); the light Bay Lakes a low percentage (White-17\%, Waccamaw-9\%): If these percentages are plotted against the indices of productivity (Table 29), it can be seen that the two numbers are even more closely correlated than in the case of the pored lateral-line scales. The population of E. f. fusiforme in the Cape Fear River proper has a percent $(7 \%)$ much closer to the White Lake population than to the populations in the dark Bay Lakes. Therefore, it appears that under similarly unproductive conditions in each of the dark Bay Lakes, selection (or the environment?) has acted to produce a form with a reduced number of infraorbital pores as well as a reduced number of pored lateral-line scales. Ellis Lake has $47 \%$ of its individuals with $1+3$ pores and so falls in between the dark and light Bay Lakes in this character. The populations of E. f. barratti with reduced numbers of pored lateral-line scales are of less help in this situation because the normal number for this subspecies is $1+3$. All the populations with reduced numbers of pored lateral-line scales have a higher percent of $1+3$ pores than do the populations from which they are probably derived: Crystal Lake, Ga., population
$(92 \%)$ compared with the surrounding Suwannee population $(57 \%)$, St. Cloud, Fla. $(97 \%)$ and the surrounding St. Johns population $(86 \%)$, and Orlando, Fla. $(91 \%)$ and the St. Johns population $(86 \%)$.

One peculiar population of E. $f$. barratti (Ogeechee, Ga.) has an abnormally low percent $(7 \%)$ of individuals with $1+3$ pores. Some of the western populations of E. f. barratti (Table 24) have 100\% $1+3$ pores (Pearl-Pontchartrain, La. and Red River) as does also the population from the French Broad ("barratti appalachia").

Condition of Preopercle (Table 24): Hubbs and Cannon (1935:29-30) char-

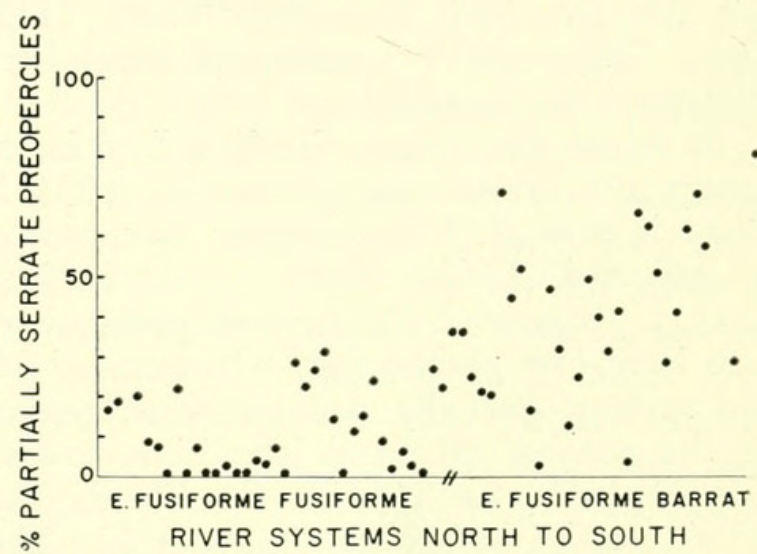

Figure 15. Percent of individuals with partially serrate preopercles by river systems from north to south in Etheostoma fusiforme.

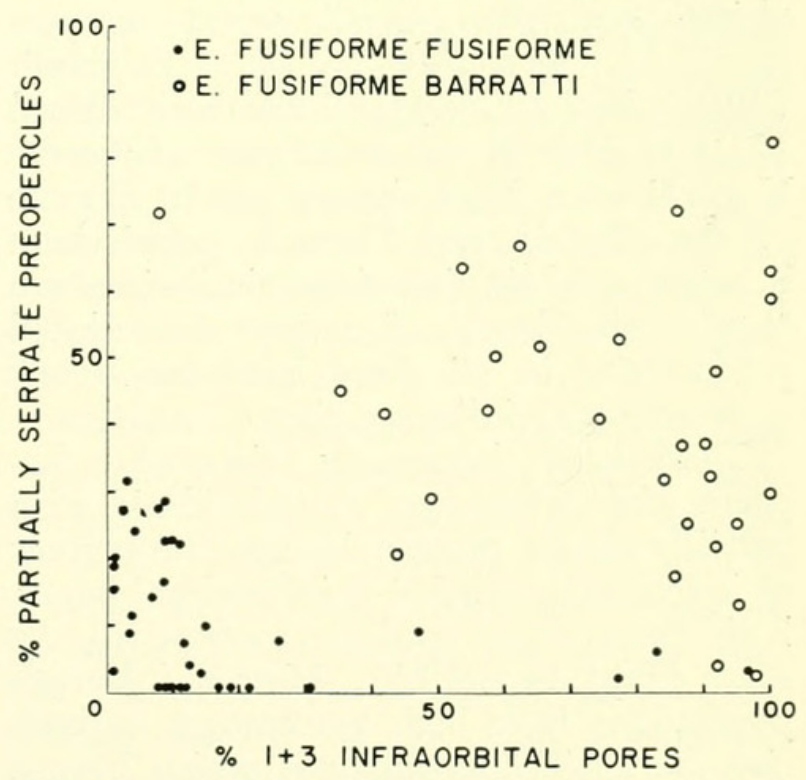

Figure 16. Correlation between percent of individuals with $1+3$ infraorbital pores and percent of individuals with partially serrate preopercles by river systems in Etheostoma fusiforme. 
acterized all the species of the subgenus Hololepsis, except serriferum, as having the "preopercle strictly entire." Bailey (1950: 315 ) has shown that E. fusiforme barratti has some serrae on the preopercle. This was one of the main characters that he used to distinguish his Hololepis barratti appalachia. There is a tendency toward a partially serrate preopercle in most populations (Table 24). This character can be used to divide E. fusiforme into two subspecies. Most populations of E. f. fusiforme have less than $25 \%$ of the specimens with serrae present while most populations of E. f. barratti have serrae in more than $25 \%$. There is a tendency for the percentage to increase southward, with a break between the Pee Dee and Waccamaw rivers (Fig. 16). There are a number of exceptions that must be discussed.

In all of the North Carolina Bay Lakes except the Waccamaw population $(23 \%)$ there is a much lower percent than would be expected $(0 \%$ in White to $9 \%$ in Ellis Lake). Several E. $f$, barratti populations also have low percentages. Three of these are at least partially neotenic with regard to the number of pored lateral-line scales: Crystal Lake, Ga. (4\%), St. Cloud, Fla. $(3 \%)$, and Okeechobee, Fla. $(13 \%)$. The Orlando populations do not show this tendency as they did in the number of pored lateral-line scales. A few typical E. $f$. barratti populations also have a low percentage of individuals with partially serrate preopercles: St. Johns, Fla. (17\%), Savannah $(20 \%)$, Red $(17 \%)$, and Combahee-Broad $(21 \%)$. Here is one more case where the North Carolina Bay Lakes are similar to some of the Florida and Georgia populations. It seems unlikely that these similarities are merely coincidental. Somehow the reduced productivity in all these lakes has acted, or is acting to influence these characters.

There is an interesting relationship between the percentage of individuals with partially serrate preopercles and the percent of individuals with $1+3$ infraorbital pores: both percentages tend to increase to the south (Figs. 14 and 15). Most E. f. barratti populations have high percentages in both characters. The populations which have a low percent of partially serrate preopercles have a high percent of $1+3$ individuals. If one percentage is higher than usual in a population of $E$. $f$, fusiforme the other is then lower than usual. For example, the dark Bay Lakes have a high percent with $1+3$ pores $(77 \%, 83 \%$, and $97 \%)$ but the partially serrate percent is very low $(2 \%, 6 \%$, and $3 \%$ respectively). Some populations have the partially serrate percent relatively high, for example Potomac $(31 \%)$, Delaware River $(28 \%)$, other Cape Fear (28\%), and Chesapeake Bay $(27 \%)$ but the values of their $1+3$ percentages are low: $3 \%, 9 \%, 7 \%$, and $2 \%$ respectively. The percent of individuals having $1+3$ infraorbital pores has been plotted by populations against the percent of individuals having partially serrate preopercles in the same drainages. Most populations of E. f. fusiforme are found along the edge of Fig. 16, below $25 \%$ partially serrate preopercles and extending up to nearly $100 \% 1+3$ infraorbital pores while the populations of E. f. barratti are limited to the central portion of the figure.

Preoperculomandibular Pores (Table 45): The range in E. f. fusiforme is six to eleven; eight to ten in E. f. barratti, with the mode always nine. Populations from both Raritan Bay, N. J. and White Lake, N.C. have means ( 8.30 and 8.34 ) considerably below the over-all mean (8.9) .

Coronal Pore (Table 47): As Bailey and Frey (1951:200) pointed out, this character is difficult to use. They reported that the pore was frequently absent in populations in White and Ellis lakes and present in the other Bay Lakes populations. This appears to be true although in the case of White Lake there were only a few specimens in which the condition could be satisfactorily determined. In most other populations the pore was usually present, although its development varied, sometimes being a rather long posterior-extending tube with an external opening, and other times being just an opening at the junction of the two medial sidebranches of the supraorbital canal. Perhaps further study of this pore would be of value.

Supratemporal Canal (Table 47): This canal is typically complete in adult E. fusiforme and incomplete in young and juveniles (see development in E. f. fusiforme and E. f. barratti). Table 31 shows the normal development in the Long Island population. There are differences between populations. For example, Bailey and Frey (1951:200) cited the incomplete na- 
ture of the supratemporal canal in the Singletary and Salters lakes populations as an example of local variation in a character. Development in Jones Lake (Table 31) is like that in the Long Island population except that it is completed at a smaller size. The transition period is longer (ten $\mathrm{mm}$ ) in both White and Singletary lakes (Table 31); than in the Long Island and Jones Lake populations (six $\mathrm{mm}$ ). Since there are so few large specimens it is doubtful if the transition is ever completed. The transition period in the Waccamaw population is lengthened to $14 \mathrm{~mm}$. The most extreme condition is present in Salters Lake, where the transition period is entirely enclosed by the juvenile period, the largest specimens having incomplete supratemporal canals.

Since the development of the supratemporal canal is retarded relative to the growth of the gonads in the Salters, Waccamaw, Singletary, and White populations, these populations may be considered neotenic in this character. The Crystal Lake, Ga. population that was neotenic in the number of pored lateral-line scales shows the usual development of the supratemporal canal (Table 31 and development in E. fusiforme barratti).

Squamation: The value of squamation as a taxonomic character was indicated by Hubbs and Cannon (1935) in their analysis of the species of Hololepis. They gave only general descriptions of squamation characterizing E. fusiforme as "interorbital scaleless, or with one or two more or less imbedded scales," thermophilum as "interorbital with several ctenoid scales," and barratti as "interorbital well covered with ctenoid scales." They further differentiated barratti from fusiforme and thermophilum with the former having "parietals covered well toward or across median line with ctenoid scales" and the other two forms as having "parietals scaleless." Hubbs and Cannon described only the general trends. More quantitative methods were devised, as discused in section III. The squamation of the preopercle, opercle and nape is usually $100-\mathrm{X}-\mathrm{T}$, so frequency distributions for the subspecies are summarized in Table 48. However, there are significant differences in the squamation of the breast, parietal, and interorbital.
Breast Squamation (Table 25): In the northern part of the range of E. fusiforme the breast squamation is usually 100-I-C, with the amount of exposure and the tendency to become ctenoid increasing to the south. In the North Carolina Bay Lake populations, specimens were found to have all the intermediate conditions $(\mathrm{I} / \mathrm{PX}-\mathrm{C} / \mathrm{T}$, PX-T, and $\mathrm{X} / \mathrm{PX}-\mathrm{T}$ ) between imbedded cycloid scales (I-C) and exposed ctenoid scales (X-T). Most specimens in populations south of the Waccamaw River have the squamation at least I/PX-C/T. West of the Apalachicola River, Fla. the breast is usually PX-T or even X-T in the case of the Pearl-Pontchartrain, La. and Red River populations.

Parietal Squamation (Table 26): This character shows the differentiation between the two subspecies more clearly than does the breast squamation. In the northern part of the range of $E$. $f$. fusiforme, most specimens have naked parietals. The amount of squamation gradually increases toward the south. Of the North Carolina Bay Lakes, the Singletary Lake population has the parietal squamation the least well developed (mostly 5-10\%) and the White Lake population has the squamation the best developed (mostly 25-30\%). There is a break between the Waccamaw (15. $20 \%)$ and Pee Dee $(35-40 \%)$. The variation in this character is greater in E. $f$. barratti $(5-100 \%)$ than in E. f. fusiforme $(0-50 \%)$. The range within populations is also considerably greater in the southern subspecies $(5-95 \%$ in the St. Mary's, based on only 12 specimens) than in the northern subspecies $(15-60 \%$ in White Lake). This tendency has been noted for a number of other characters, in particular the interorbital squamation (q.v.).

Interorbital Squamation (Table 27): The range in E. f. fusiforme is $0-12$ (mode $0, \overline{\mathrm{x}}: 1.97$ ), while that of E. f. barratti is 1.37 scales (mode 10, $\overline{\mathrm{x}}: 13.15$ ) (Table 46). This difference seems to be sufficient to divide the species into two subspecies but does not seem great enough, because of the wide overlap, to merit specific recognition. The northsouth clinal nature of the variation in E. $f$. fusiforme is clearly demonstrated in the table. There is a gap between Waccamaw on the north and the Pee Dee River on 
the south. There seems to be more intrapopulation and relatively less interpopulation variation in $E$. f. barratti.

\section{TAXonomic CONClusions}

Etheostoma fusiforme is the most variable species of the subgenus Hololepis. There are two ways to treat this variation: to name all distinguishable populations; or to describe the variations and try to understand them without the use of names. Minor differences beween populations should not be formally recognized because of the great plasticity of some characters in fishes. A number of environmental factors effect some meristic characters in some fishes. Perhaps the most important of these is the effect of water temperature on such characters as the number of vertebrae and fin rays (Täning, 1952; Blaxter, 1956; and others).

There are four patterns of variation in the characters studied in Etheostoma fusiforme. First, there are the characters that showed little or no variation; number of anal spines, anal rays, preoperculomandibular pores, interorbital pores, pectoral rays, pelvic rays, caudal rays, branchiostegals, and the squamation of the preopercle, opercle, and nape. In the second type, characters vary from population to population in an apparently random fashion (total lateralline scales, dorsal spines, and dorsal rays). The third type is clinal; the breast, parietal, and interorbital show increasing development of squamation from north to south. The percent of individuals with $1+3$ infraorbital pores and with partially serrate preopercles also increases from north to south. The fourth type is the most interesting: the incomplete development of some characters (neoteny) in populations in the unproductive North Carolina Bay Lakes and in a few Florida and Georgia lakes. This has been noted in the greatly reduced number of pored lateral-line scales, the failure of the supratemporal canal to become closed, the reduced number of scales above and below the lateral line, and the percentage of individuals with $1+3$ infraorbital pores.

The major taxonomic problem was to decide which populations merit nomenclatorial recognition. I believe the differences between Hubbs and Cannon's three species, fusiforme, thermophilum, and barratti, are due to clinal variations (squamation, infraorbital pores, development of the pored lateral line) and to developmental variations (infraorbital pores and pored scales in thermophilum). The subspecies of fusiforme recognized by Hubbs and Cannon (1935) were based on a combination of: random variations (total lateral-line scales in fusiforme insulae and f. metaegadi and dorsal spines in fusiforme insulae) and clinal variations (interorbital squamation in three groups: $f$. atraquae and f. erochroum; f. fusiforme and f. metaegadi; f. insulae). This was coupled with the improper presentation of counts from both sides of individuals (see section IV) and inadequate sampling between the ranges of the forms they recognized. J. R. Bailey's barratti appalachia is almost certainly based upon an introduced population (Bailey, Winn, and Smith, 1954). It is slightly different in having a higher percentage of specimens with partially serrate preopercles. The most interesting case is surely thermophilum oligoporum. It seems clear that the form in the dark North Carolina Bay Lakes has differentiated independently in each lake, probably as a result of the unproductive conditions in these lakes. Thus all the subspecies of E. fusiforme and of E. thermophilum are reduced to synonymy under $E$. fusiforme fusiforme while E. barratti and E. barratti appalachia become E. fusiforme barratti.

\section{Etheostoma saludae (Hubbs and Cannon )}

Hololepis saludae-Hubbs and Cannon, 1935:50-52, pl. I-III (original description); Fowler, 1945:40, 196 (Saluda Co., S. C.); Freeman, 1952a:37 (Broad R., Richland Co., S. C.).

Etheostoma saludae-Bailey and Gosline, 1955:20, 44 (number of vertebrae); Eddy, 1957:220; Moore, 1957:198; Collette, 1961: 2051.

Types-Holotype, UMMZ 107079; 21 mm juvenile; S. C., Saluda Co., Richland Cr., trib. to Lake Murray, $10 \mathrm{mi}$. SE of Saluda; June 21, 1933; E. M. Burton. Paratypes, the other 16 specimens examined by Hubbs and Cannon (1935:50).

Diagnosis-One or two anal spines; both interorbital pores usually present; infraorbital pores either $1+4$ or $1+3$; nape squamation usually less than $60 \%(\overline{\mathrm{x}}: 15 \%)$ : 
TABLE 33.

Number of total lateral-line scales in Etheostoma collis and E. saludae

\begin{tabular}{|c|c|c|c|c|c|c|c|c|c|c|c|c|c|c|c|c|c|}
\hline \multirow{3}{*}{$\begin{array}{l}\text { Form and drainag } \\
\text { collis lepidinion } \\
\text { Roanoke }\end{array}$} & 35 & 36 & 37 & 38 & 39 & 40 & 41 & 42 & 43 & 44 & 45 & 46 & 47 & 48 & 49 & 50 & $\overline{\mathrm{x}}$ \\
\hline & & & & & & & & & & & & & & & & & \\
\hline & & & & & 3 & 1 & 7 & 5 & 2 & 5 & 2 & 3 & 4 & & & & 43. \\
\hline $\begin{array}{l}\text { Neuse } \\
\text { Cape Fear }\end{array}$ & 1 & 2 & 1 & - & 2 & 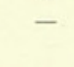 & 1 & & & & & $1 *$ & $* *$ & & & & - \\
\hline ollis co & & & & & & & & & & & & & & & & & \\
\hline & & & & & & & & 1 & & 8 & 3 & 5 & 4 & - & 1 & & 44. \\
\hline Roc & & & & & & 1 & - & 2 & 3 & 4 & 4 & 1 & 2 & 3 & 1 & & \\
\hline $\begin{array}{l}\text { Cate } \\
\text { "Sal }\end{array}$ & & & 1 & - & 1 & 1 & 1 & 1 & 1 & - & $\dot{2}$ & 1 & & & & & \\
\hline $\begin{array}{l}\text { "San } \\
\text { saludae }\end{array}$ & & & & & & & & 1 & 1 & & & & & & & & \\
\hline saludae & & 1 & 2 & 8 & 8 & 11 & 12 & 10 & 17 & 9 & 7 & 1 & 1 & 1 & 1 & 1 & 41.78 \\
\hline
\end{tabular}

* Count of holotype of E. c. lepidinion.

** This specimen counted on right side.

breast naked. Maximum size of males 42.5 mm SL. (CU 35019) and females $43.5 \mathrm{~mm}$ (CU 35029).

Coloration-Hubbs and Cannon's (1935: $51-52$ ) description was based entirely upon immature specimens $(17-22 \mathrm{~mm})$. No adult non-breeding males were available to me, but they probably are similar to the females. The pigmentation of $E$. saludae is similar to that of E. collis.

The spinous dorsal fin of the non-breeding female has few to a moderate number of small to medium sized melanophores scattered on the membrane. The soft dorsal fin is barred on the rays and rectangular blotches composed of 10-15 melanophores are present on the membranes. The anal fin is clear or has a few small melanophores on the proximal portion of the membranes. The pectoral fin membranes are clear, but melanophores outline the rays. The pelvic fin, belly, and breast lack pigment. The caudal is barred. There are large and small melanophores scattered on the cheek. The suborbital, preorbital, and postorbital bars are all prominent. The pored portion of the lateral line is light. The median basi-caudal spot is prominent; dorsal and ventral spots are sometimes present. The sides are irregularly mottled with brown; up to eight lateral blotches may be present. The genital papilla is unpigmented. Most specimens have about seven dorsal saddles, two before the first dorsal fin, two under each dorsal fin and one posterior to the second dorsal fin.

Some breeding females have more melanophores on the second dorsal fin membranes than do non-breeding females. The anal fin pigmentation varies, even within a single collection, from immaculate to a moderate number of melanophores scattered over the membrane. Figure 17 shows the pattern of a breeding female E. saludae compared with E. collis.

Most parts of the body and fins of the breeding males are colored like the females; other areas are darker. The spinous dorsal has more melanophores; they are concentrated on the first two or three membranes, and there is a tendency toward a median band. The second dorsal fin has about 30-40 melanophores in each rectangular blotch. The anal and pelvic fins and the belly and breast are uniformly covered with small to medium melanophores. The cheek is darker in the male than in the female. The suborbital bar is more prominent in some breeding males. There is more pigment on the distal edges of the pored lateral-line scales. Dorsal saddles and blotches are usually absent. Figure 18 compares the patterns of breeding males of E. collis and E. saludae.

Genital Papilla-A moderately elongate blunt tube in breeding females. A specimen taken on April 1 (CU 25982) has a genital papilla $1.5 \mathrm{~mm}$ long and $0.9 \mathrm{~mm}$ thick at the base. The genital papilla is like that of E. f. fusiforme (Fig. 1f).

Breeding Tubercles-Present on anal and pelvic fins. Males taken on April 16 (CU 35019) have tubercles on most of the ventral surface of pelvic rays one to four and along the distal seven-eighths to threequarters of the anal rays. The tubercles on the anal rays are somewhat larger than those on the pelvic rays. Another collection taken on March 14 (CU35036) contains a male with large tubercles on the distal three-quarters of anal rays one and two 

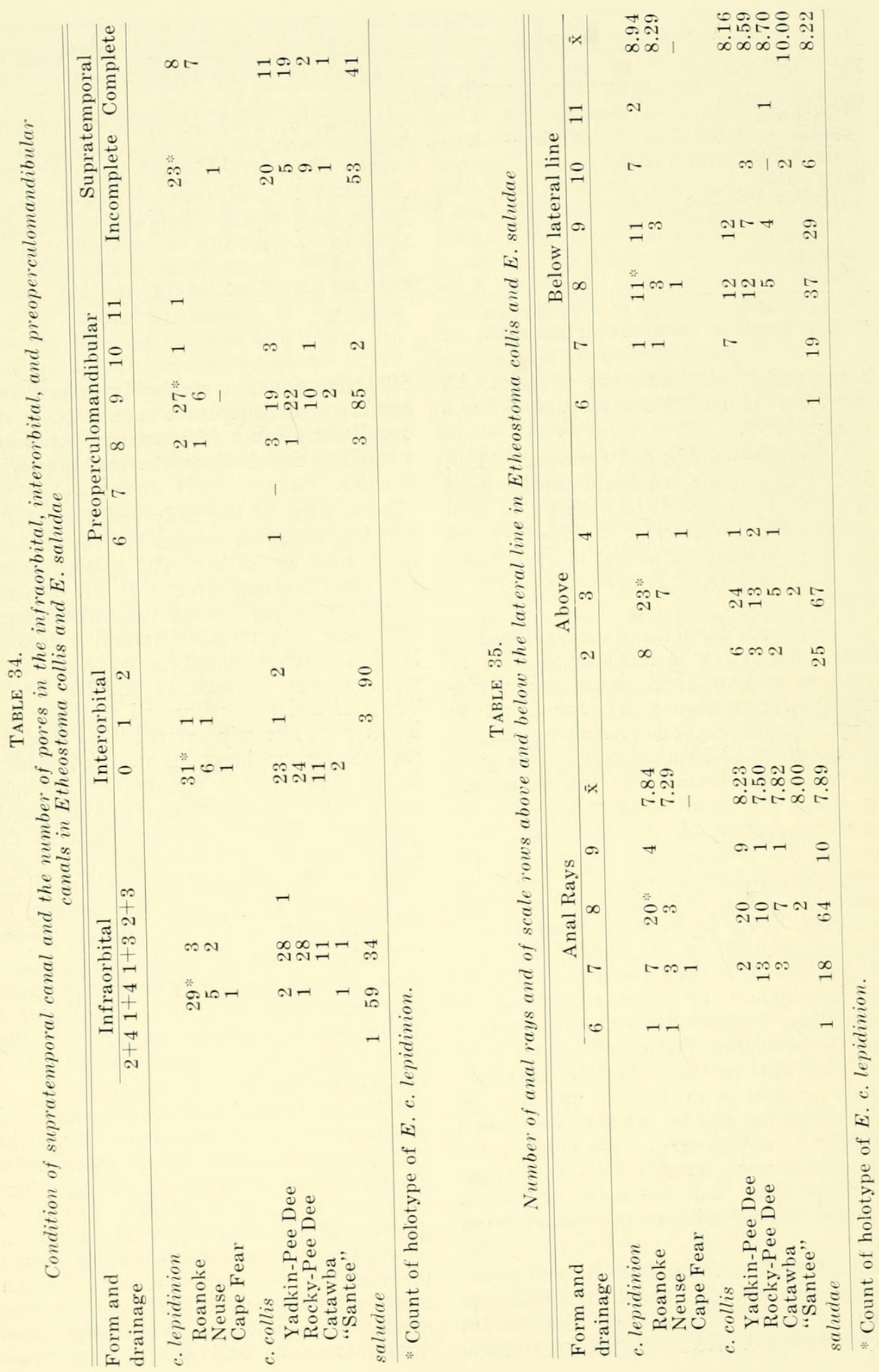

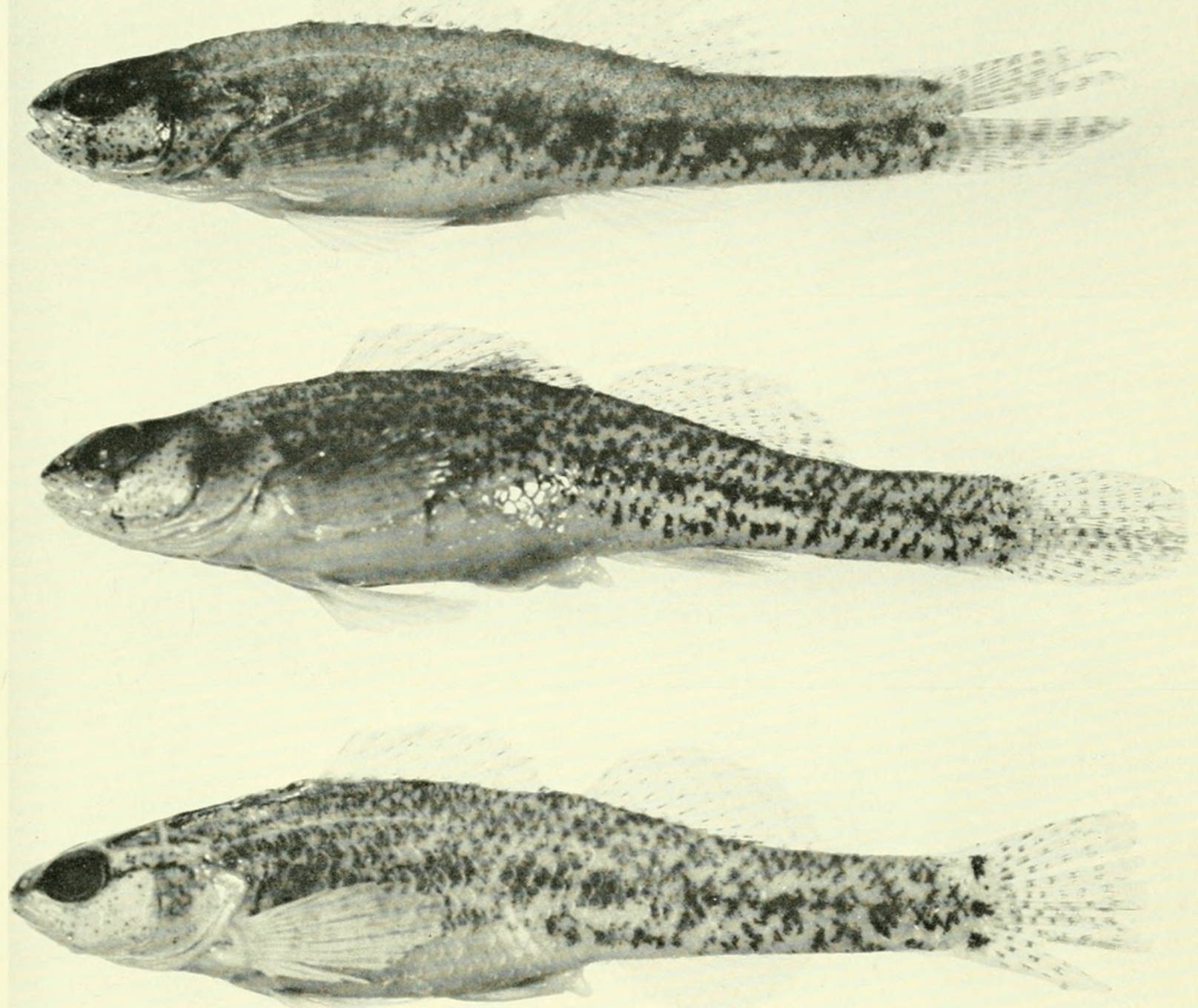

Figure 17. Breeding patterns of female Etheostoma collis and E. saludae. (upper) E. collis LEPIDINION, paratype; CU 29992; $38.6 \mathrm{~mm}$; Va., Charlotte Co., Roanoke dr.; Mar. 31, 1956. (middle) E. collis collis; CU 11988; $41.3 \mathrm{~mm}$; N.C., Davidson Co., Yadkin-Pee Dee dr.; Mar. 22, 1958. (lower) E. saludae; CU 35030; 40.7 mm; S.C., Saluda Co., Saluda dr.; Apr. 16, 1954. (Photograph by Douglass M. Payne)

and on the distal three-quarters of all the pelvic rays where the tubercles are scattered and smaller. This is essentially the same distribution as found in E. collis collis (Fig. 1g).

Habitat-Field notes of E. C. Raney for four spring collections (CU 17542, 25966, 25982,26061 ) indicate the habitat to be small woodland streams, 5-15 feet wide, 2-4 feet deep, with a flow of 5-10 cubic feet per second, current slow to moderate, and the bottom consisting of sand, gravel, and bedrock.

Distribution - Limited to Piedmont streams of the Saluda and Broad Rivers, which are tributaries of the Congaree, the southern branch of the Santee River in South Carolina. Figure 3 shows the distribution of the collections examined.

Specimens Examined-Saluda-Broad Dr., S.C.Laurens Co. : CU $19745(1,39)$; Bush Cr. $1.5 \mathrm{mi}$ SW of Kinards on SC 560 : March 28,1951 . Lexington Co.: CU 35035 (3, 30-41): Kinlev Cr. mi. S of Irmo, $1 / 2 \mathrm{mi}$. W SC 36 : March 18,1954 $\mathrm{CU} 35024(6,25-38) ; \mathrm{CU} 35026(6,25-37)$ : SC $361 \mathrm{mi}$. W of US 76 ; March 27, 1954. CU 35027 (1. 37) : SC 20, 1 mi. S of Little Mt. : March 27 1954. CU $25966(1,32)$ : Rawl Cr. 2 mi. S of Kino on SC 107 , trib. $1 / 2$ mi. from Saluda R. April 1, 1954. CU 25982 (12, 25-39); trib. of Saluda R. about $1 \mathrm{mi}$. from Saluda R., $2 \mathrm{mi}$. S of Irmo on SC sec. 36: April 1, 1954. Newberry Co. CU 35029 (1, 44); Timothy Cr. SC 42, 2 mi. IV of Prosperity ; Feb. 20, 1954. CU 35037 (1, 42) Garrison Cr. SC 58,6 mi. SW Kinards: Aug. 5. 1954. Richland Co. : CU 26061 (14, 2842$)$ : Nicholas Cr. trib of Broad R, 4.5 mi. S of Broad R. $6 \mathrm{mi}$. SE Ballentine on SC sec. 129; April 1, 1953. 


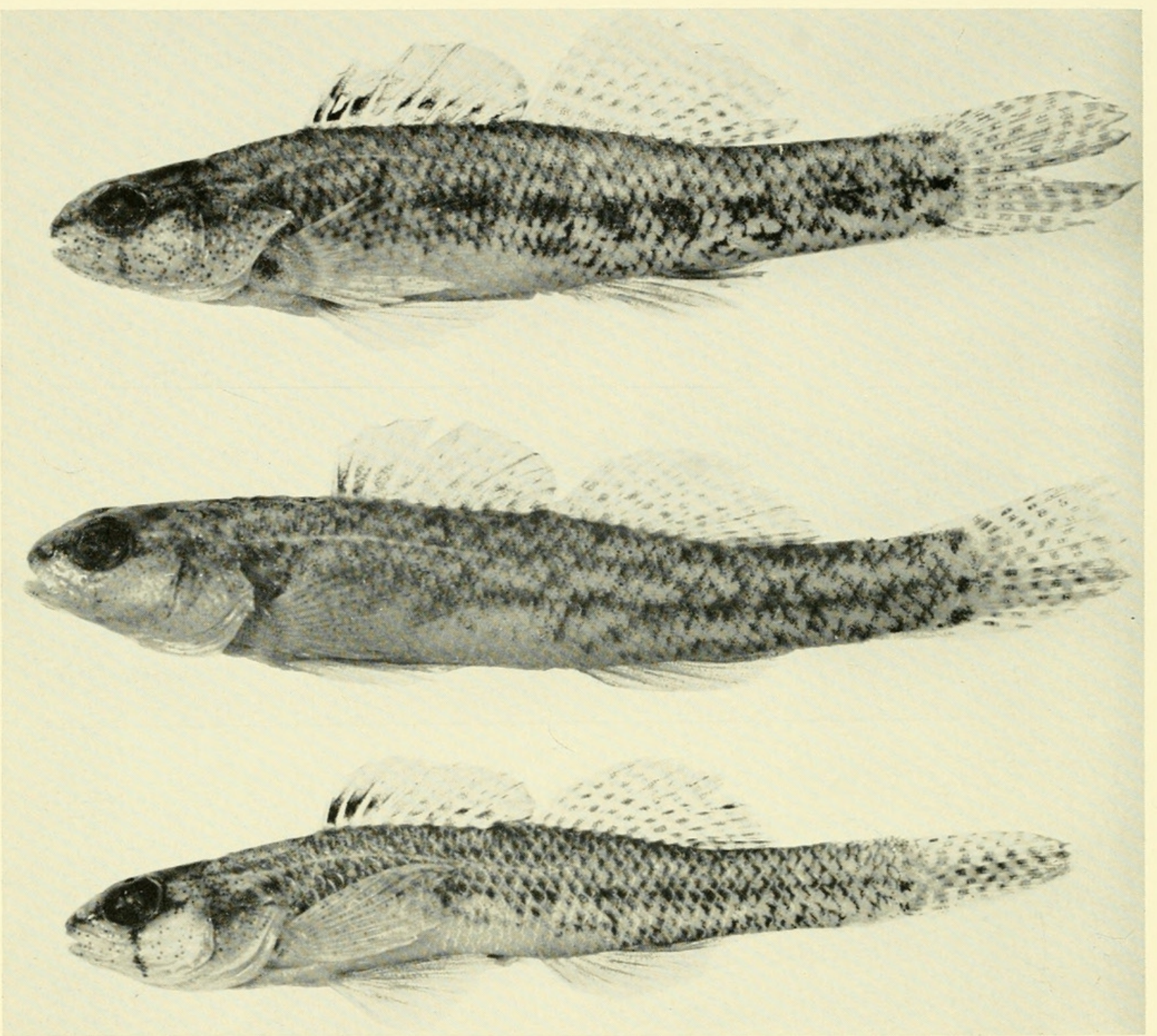

Figure 18. Breeding patterns of male Etheostoma collis and E. saludae. (upper) E. collis LEPIDINION, holotype; USNM 179847; $37.6 \mathrm{~mm}$; Va., Charlotte Co., Roanoke dr.; Mar. 31, 1956. (middle) E. collis collis; CU 31663; $39.5 \mathrm{~mm}$; N.C., Stanly Co., RockyPee Dee dr.; Mar. 31, 1958. (lower) E. saludae; CU 35030; 34.9 mm; S.C., Saluda Co., Saluda dr.; Apr. 16, 1954. (Photograph by Douglass M. Payne)

Saluda Co.: UMMZ 107077 (4, 17-21) ; Moore's Cr., trib to Lake Murray, 6 mi. SE of Saluda: June 21, 1933 ; paratypes. UMMZ 107078 (2, 2022), USNM $94685(1,22)$, Chicago Nat. Hist. Ius 38331 ( 1,17$)$, out of Charleston Mus. 33.149 .1 , paratypes and UMMZ $107079(1,21)$ holotype of Hololepis saludae; Richland Cr., trib. to Lake Murray, 10 mi. SE of Saluda; June 21, 1933 CU $17542(15,28-40)$ : trib. of Little Salu. da R., 2.1 mi. $N$ of Saluda on rt. 19: March 23 . 1950. CU $35023(1,32) ; 1$ mi. NE Cherry Hill School, $7 \mathrm{mi}$. E of Saluda on SC 192; Oct. 16 , 1953. CU 35033 (2, 29-31); Richland Cr., 4 mi. $\mathrm{E}$ of Saluda on SC 43 : Oct. 16, 1953. CU 35032 (2, 37-38) : Moore's Cr., $3 \mathrm{mi}$. W of Batesburg on SC 57 ; Mar. 14, 1954. CU $35031(1,40)$; Clouds Cr.. 3 mi. N of Ridge Spring on SC 57 ; Mar. 14. 1954. CU $35036(3,32-40)$; Mine Cr., 6 mi. S of Saluda on SC 193: Narch 14. 1954. CU 35022 $(3,31-36)$; S branch of Red Bank Cr., 5 mi. SW of Saluda on SC 84; April 6, 1954. CU 35034 (1. 36) ; S branch of Big Cr. on $\mathrm{SC} 83$ at Trinity Church, $5 \mathrm{mi}$. NW of Saluda; April 6, 1954. CU 35021 (1.37) : Ready Cr.. 1/2 mi. E of Ready Cr. School, $5 \mathrm{mi}$. $\mathrm{N}$ of Ward : April 16, 1954. CU $35019(3,33-43)$; $\mathrm{N}$ branch of Mine Cr., $3 \mathrm{mi}$. N of Ward on SC 193; April 16, 1954. CU 35030 $(6,33-43)$; S. branch of Red Bank Cr., on SC
186, 5 mi. SW of Saluda: April 16, 1954. CU $35020(2,25-28)$; a south branch of Red Bank Cr., SC 84 at Salem Church, $5 \mathrm{mi}$. IN of Saluda; April 16. 1954. CU 35028 (1, 39) : Big Cr., 5 mi. NW of Saluda Shiloh Church on SC 39: April 6 . 1954. CU $35025(2,31-36)$; Little Saluda R., 5 mi. NE of Saluda on SC 39 ; Oct. $16,1954$.

Etheostoma collis lepidinion subsp. nov. Etheostoma collis new subspecies-Collette, 1961:2051.

Types-Holotype, USNM 179847; 37.6 mm male; Va., Charlotte Co., trib. of Horsepen Cr., $2.4 \mathrm{mi}$. NW of Wylliesburg on Va. 607; March 31, 1956; Raney, Collette, New, Cole, Robins; ECR 2787 and BBC 160. One of a series of nine specimens (CU 29992). Paratypes are all the other specimens examined except for $\mathrm{CU}$ 25187 from the Cape Fear River. 

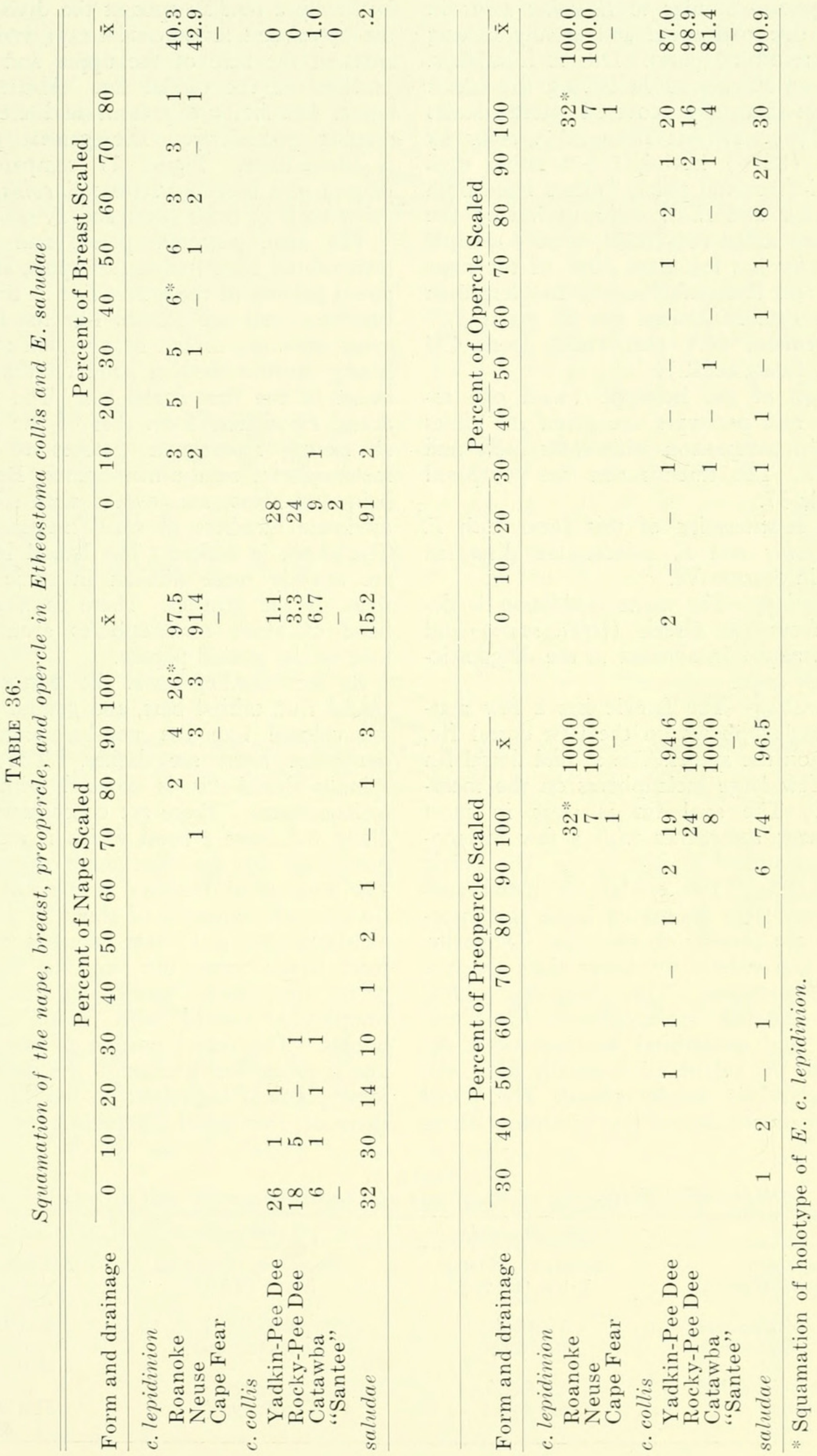
Diagnosis-Similar to E. collis collis in having one anal spine and usually lacking both interorbital pores. Differs from E. c. collis and E. saludiae in having the breast at least partially covered with scales ( $\bar{x}: 41 \%)$. Differs from E. c. collis by usually $(88 \%)$ having $1+4$ rather than $1+3$ infraorbital pores. Differs from both $E$, saludae and E. C. collis in having the nape well scaled (80-100\%, $\bar{x}: 96 \%)$, while E. c. collis has less than $20 \%$ of the nape scaled and $E$. saludae usually has less than $60 \%$ scaled. Maximum size of males 37.7 $\mathrm{mm}$, females $40.1 \mathrm{~mm}$ (both from CU 34544, Roanoke R.).

Counts of the holotype (with one asterisk) and paratypes are given in Tables $32-36$ in comparison with collis collis and saludae. The three forms are compared in Table 37.

The relationships of this form with $E$. collis collis and E. saludae are discussed above in Section VI.

Etymology-The name lepidinion is derived from the Greek (lepis, scale) and (inion, nape) in allusion to the diagnostically scaly nape.

Coloration-The female has a few scattered melanophores on the first dorsal fin, mostly on the spines. The second dorsal fin has a few large melanphores on the membranes. The anal fin is clear in most specimens; sometimes with a few melanophores scattered on the rays. The pelvic fin is clear. The caudal fin membranes are clear; large brown or black chromatophores are present on the rays. The belly, breast and usually the lower sides are free of melanophores. The cheek has a few large scattered melanophores. The preorbital and postorbital bars are well developed; the suborbital is usually faint; the supraorbital is usually absent. The pored portion of the lateral line is clear. There is usually a median spot at the division of the upper and lower caudal rays, and faint spots at the base of the upper and lower portions of the caudal fin. About eight lateral blotches are present and are most distinct posteriorly. The genital papilla is immaculate. Figure 17 compares the pattern of a breeding female E. collis lepidinion with E. collis collis and E, saludae.

The anal, pectoral, pelvic and caudal fins, orbital bars, basi-caudal spots, and the pored portion of the lateral line in the nonbreeding male are colored like the female; other areas are darker. Many small melanophores form a median band on the membrane of the first dorsal fin. The second dorsal fin differs from that of the female in having rectangular patches of small melanophores on the membranes. Both the belly and breast are covered with slight to moderate numbers of small melanophores. The cheek is darker. The lateral blotches are slightly more distinct in some males than in the females. There is a narrow band of small melanophores around the base of the genital papilla.

In the breeding male the pectoral and caudal fins, orbital bars, and genital papilla are colored like the non-breeding male; the other areas are darker. The entire spinous dorsal fin is covered with small melanophores. These are concentrated medially and form a band which is especially prominent on the first three membranes. The rectangular blotches in the soft dorsal fin are each composed of about 25 (15-50) melanophores, and these blotches tend to form bands across the fin. The anal and pelvic fins, belly, breast and cheeks are completely covered with small melanophores. The pored portion of the lateral line is prominent because of the dark sides; some pigment is present on the distal portions of the pored lateral-line scales, in-

TABLE 37.

Differential characters of the forms of Etheostoma collis and E. saludae

\begin{tabular}{lccc}
\hline \hline Form & collis lepidinion & collis collis & saludae \\
\hline River system & Roanoke, Neuse & Pee Dee, Catawba & Saluda, Broad \\
Infraorbital pores & $1+4(90 \%)$ & $1+3(95 \%)$ & $1+4(65 \%)$ \\
& $0(95 \%)$ & $0(95 \%)$ & $1+3(35 \%)$ \\
Interorbital pores & $80-100 \%$ & Less than $20 \%$ & $(95 \%)$ \\
Nape $(\%$ scaled) & $10-80 \%$ & Usually less \\
Breast $(\%$ scaled) & always I & naked & than $60 \%$ \\
Anal spines & & always I & naked \\
& & II $(70 \%)$ \\
\end{tabular}


terrupting the narrow light line. The median basi-caudal spot is prominent; the dorsal and ventral ones diffuse. The sides usually show less distinction between the darker blotched portion below the lateral line and the lighter upper portion. Figure
18 is a comparison of the pattern of a breeding male with $E$. collis collis and $E$. saludae.

Genital Papilla-The genital papilla of the breeding female is a moderately elongate tube like that of E. fusiforme (Fig. 1f).

TABLE 38.

Number of total lateral-line scales in the species of the subgenera Hololepis and Villora

\begin{tabular}{|c|c|c|c|c|c|c|c|c|c|c|c|c|c|c|c|c|c|c|c|}
\hline Species & 32 & 33 & 34 & 35 & 36 & 37 & 38 & 39 & 40 & 41 & 42 & 43 & 44 & 45 & 46 & 47 & 48 & 49 & 50 \\
\hline $\begin{array}{l}\text { Hololepis } \\
\text { serriferum } \\
\text { gracile } \\
\text { zoniferum } \\
\text { f. barratti } \\
\text { f. fusiforme } \\
\text { saludae } \\
\text { c. lepidinion } \\
\text { c. collis } \\
\text { Villora } \\
\text { okaloosae } \\
\text { edwini } \\
\end{array}$ & i & 6 & $\begin{array}{r}24 \\
4 \\
\end{array}$ & $\begin{array}{l}34 \\
12 \\
\end{array}$ & $\begin{array}{l}13 \\
79 \\
\end{array}$ & $\begin{array}{r}2 \\
1 \\
1 \\
\\
1 \\
217 \\
\end{array}$ & $\frac{8}{-}$ & $\begin{array}{l}8 \\
5 \\
1\end{array}$ & $\begin{array}{r}1 \\
11 \\
1 \\
3\end{array}$ & $\begin{array}{r}12 \\
2 \\
5 \\
12 \\
8 \\
2\end{array}$ & $\begin{array}{r}21 \\
1 \\
2 \\
12 \\
10 \\
5 \\
5\end{array}$ & $\begin{array}{r}27 \\
8 \\
20 \\
17 \\
2 \\
11\end{array}$ & $\begin{array}{r}1 \\
34 \\
16 \\
46 \\
9 \\
5 \\
12\end{array}$ & $\begin{array}{r}79 \\
2 \\
28 \\
64 \\
7 \\
2 \\
9\end{array}$ & $\begin{array}{r}\overline{91} \\
1 \\
39 \\
118 \\
1 \\
4 \\
7\end{array}$ & $\begin{array}{r}3 \\
123 \\
6 \\
72 \\
152 \\
1 \\
4 \\
6\end{array}$ & $\begin{array}{r}8 \\
130 \\
7 \\
121 \\
226 \\
1 \\
2 \\
3\end{array}$ & $\begin{array}{r}11 \\
89 \\
5 \\
132 \\
220 \\
1 \\
2\end{array}$ & $\begin{array}{r}27 \\
70 \\
1 \\
165 \\
229 \\
1\end{array}$ \\
\hline Species & 51 & 52 & 53 & 54 & 55 & 56 & 57 & 58 & 59 & 60 & 61 & 62 & 63 & 64 & 65 & 66 & $\mathrm{~N}$ & & $\overline{\mathbf{x}}$ \\
\hline $\begin{array}{l}\text { Hololepis } \\
\text { serriferum } \\
\text { gracile } \\
\text { zoniferum } \\
\text { f. barratti } \\
\text { f. fusiforme } 2 \\
\text { saludae } \\
\text { c. lepidinion } \\
\text { c. collis }\end{array}$ & $\begin{array}{r}32 \\
68 \\
1 \\
165 \\
234 \\
\end{array}$ & $\begin{array}{r}40 \\
33 \\
1 \\
158 \\
198\end{array}$ & $\begin{array}{r}42 \\
24 \\
1 \\
138 \\
160\end{array}$ & $\begin{array}{r}41 \\
4 \\
102 \\
124\end{array}$ & $\begin{array}{r}46 \\
2 \\
66 \\
65\end{array}$ & $\begin{array}{l}60 \\
66\end{array}$ & $\begin{array}{l}51 \\
31\end{array}$ & $\begin{array}{l}29 \\
14\end{array}$ & $\begin{array}{l}17 \\
13\end{array}$ & $\begin{array}{r}10 \\
6\end{array}$ & 5 & $\begin{array}{l}3 \\
2\end{array}$ & 2 & 1 & - & 1 & $\begin{array}{r}366 \\
810 \\
28 \\
1389 \\
2006 \\
90 \\
40 \\
62\end{array}$ & & $\begin{array}{l}54.05 \\
47.60 \\
47.46 \\
51.37 \\
50.18 \\
41.78 \\
42.13 \\
44.19\end{array}$ \\
\hline $\begin{array}{l}\text { Villora } \\
\text { olaloosae } \\
\text { edwini } \\
\end{array}$ & & & & & & & & & & & & & & & & & $\begin{array}{r}79 \\
644\end{array}$ & & $\begin{array}{l}34.70 \\
37.67\end{array}$ \\
\hline
\end{tabular}

TABLE 39.

Number of pored lateral-line scales in the species of the subgenera Hololepis and Villora

\begin{tabular}{|c|c|c|c|c|c|c|c|c|c|c|c|c|c|c|c|c|c|c|c|}
\hline Species & 0 & 1 & 2 & 3 & 4 & 5 & 6 & 7 & 8 & 9 & 10 & 11 & 12 & 13 & 14 & 15 & 16 & 17 & 18 \\
\hline $\begin{array}{l}\text { Hololepis } \\
\text { serriferum } \\
\text { gracile } \\
\text { zoniferum } \\
\text { f. barratti } \\
\text { f. fusiforme } \\
\text { saludae } \\
\text { c. lepidinion } \\
\text { c. collis } \\
\text { Villora } \\
\text { okaloosae } \\
\text { edwini } \\
\end{array}$ & 11 & $\frac{1}{7}$ & $\begin{array}{r}5 \\
12\end{array}$ & $\begin{array}{r}4 \\
11\end{array}$ & $\frac{2}{8}$ & $\begin{array}{r}3 \\
14 \\
1 \\
1\end{array}$ & $\begin{array}{r}3 \\
23 \\
1 \\
-\end{array}$ & $\begin{array}{r}1 \\
4 \\
23 \\
- \\
-\end{array}$ & $\begin{array}{l}\overline{7} \\
34 \\
- \\
-\end{array}$ & $\begin{array}{r}\overline{7} \\
46 \\
1 \\
3\end{array}$ & $\begin{array}{r}1 \\
7 \\
53 \\
1 \\
1 \\
5\end{array}$ & $\begin{array}{r}\overline{13} \\
113 \\
\overline{5} \\
\overline{6}\end{array}$ & $\begin{array}{r}1 \\
12 \\
182 \\
3 \\
1 \\
5\end{array}$ & $\begin{array}{r}2 \\
2 \\
24 \\
300 \\
5 \\
5 \\
9\end{array}$ & $\begin{array}{r}20 \\
3 \\
32 \\
300 \\
7 \\
4 \\
5\end{array}$ & $\begin{array}{r}24 \\
6 \\
61 \\
320 \\
6 \\
6 \\
7\end{array}$ & $\begin{array}{r}49 \\
2 \\
57 \\
235 \\
11 \\
5 \\
7\end{array}$ & $\begin{array}{r}78 \\
4 \\
89 \\
172 \\
7 \\
3 \\
4\end{array}$ & $\begin{array}{r}101 \\
3 \\
106 \\
92 \\
7\end{array}$ \\
\hline & 19 & 20 & 21 & 22 & 23 & 24 & 25 & 26 & 27 & 28 & 29 & 30 & 31 & 32 & 33 & 34 & 35 & 36 & 37 \\
\hline $\begin{array}{l}\text { Iololepis } \\
\text { serriferum } \\
\text { gracile } 1 \\
\text { zoniferum }\end{array}$ & $\begin{array}{r}140 \\
3 \\
74\end{array}$ & $\begin{array}{r}1 \\
120 \\
2\end{array}$ & 121 & $61^{2}$ & $\frac{1}{45}$ & 23 & $1 \stackrel{2}{3}$ & $\begin{array}{r}3 \\
14 \\
-0\end{array}$ & $\begin{array}{l}5 \\
3\end{array}$ & 14 & 20 & 25 & 28 & 21 & 34 & 41 & 40 & 33 & 26 \\
\hline $\begin{array}{l}\text { f. barratti } \\
\text { f. fusiforme } \\
\text { saludae } \\
\text { c.lepidinion } \\
\text { c. collis }\end{array}$ & $\begin{array}{r}74 \\
68 \\
14 \\
1 \\
1\end{array}$ & $\begin{array}{r}116 \\
42 \\
3 \\
1 \\
1\end{array}$ & $\begin{array}{r}111 \\
21 \\
6 \\
1 \\
3\end{array}$ & $\begin{array}{r}105 \\
15 \\
6 \\
1 \\
1\end{array}$ & $\begin{array}{r}107 \\
5 \\
3 \\
1\end{array}$ & $\begin{array}{r}84 \\
3 \\
1 \\
1\end{array}$ & $\frac{84}{-}$ & $\begin{array}{r}76 \\
1 \\
- \\
-\end{array}$ & $\begin{array}{l}58 \\
- \\
-\end{array}$ & $\begin{array}{l}24 \\
- \\
-\end{array}$ & $\begin{array}{r}23 \\
1 \\
-\end{array}$ & 17 & 11 & 6 & 3 & 5 & - & 1 & \\
\hline $\begin{array}{l}\text { Villora } \\
\text { okaloosae } \\
\text { edwini } \\
\end{array}$ & & 2 & 5 & 9 & 23 & 48 & 62 & 101 & 112 & 97 & 48 & $\begin{array}{r}3 \\
40 \\
\end{array}$ & $\begin{array}{r}4 \\
22 \\
\end{array}$ & $\begin{array}{l}19 \\
20\end{array}$ & $\begin{array}{r}27 \\
5\end{array}$ & $\begin{array}{r}19 \\
4\end{array}$ & 6 & 2 & \\
\hline & 38 & 39 & 40 & 41 & 42 & 43 & 44 & 45 & 46 & 47 & 48 & 49 & 50 & 51 & 52 & & $\mathrm{~N}$ & & $\overline{\mathbf{x}}$ \\
\hline $\begin{array}{l}\text { Hololepis } \\
\text { serriferum } \\
\text { gracile } \\
\text { zoniferum } \\
\text { t. barratti } \\
\text { f. fusiforme } \\
\text { saludae } \\
\text { c. lepidinion } \\
\text { c. collis }\end{array}$ & 24 & 5 & 13 & 3 & 2 & 2 & - & 2 & & & & & & & & & $\begin{array}{r}348 \\
814 \\
28 \\
1349 \\
2111 \\
89 \\
36 \\
65\end{array}$ & & $\begin{array}{l}33.66 \\
19.53 \\
15.64 \\
20.65 \\
13.96 \\
16.87 \\
15.89 \\
14.66\end{array}$ \\
\hline $\begin{array}{l}\text { Villora } \\
\text { okaloosae } \\
\text { edwini } \\
\end{array}$ & & & & & & & & & & & & & & & & & $\begin{array}{r}80 \\
598 \\
\end{array}$ & & $\begin{array}{l}33.01 \\
27.02 \\
\end{array}$ \\
\hline
\end{tabular}


Breeding Tubercles-Present on the pelvic and anal fins of breeding males. Specimens taken on March 31 (CU 29992) have moderately large tubercles on the lower side of the spines and rays of the pelvic fins and on all the anal fin rays. Their distribution is similar to that in E. collis collis (Fig. 1g).

Habitat-Field notes for two Roanoke River localities (CU 29992 the type locality, and CU 34544) show the habitat to be backwater pools of small streams with a depth of 2-4 feet, width of 10-20 feet, flow of about three cubic feet per second, banks partly wooded, current slow to moderate, bottom sand overlain with some mud and with thin to thick layers of detritus.

Distribution-Like its relatives, E. collis collis and E. saludae, E. c. lepidinion is limited to Atlantic Piedmont streams. This is the most northern of the three forms and is found in the Roanoke and Neuse Rivers. The juvenile specimen from the Cape Fear River is referred to this subspecies with some question so it remains to be determined whether the range ex- tends that far south. Figure 3 shows the distribution of the collections of this form that have been examined.

Specimens Examined-All specimens are designated as paratypes except for the single specimen from the Cape Fear.

Roanoke, R., Va.-Charlotte Co.: USNM 100215 (3, 29-31); Wards Fork, trib. to Roanoke R., S of Madisonville; April 23, 1935. USNM 101330 and 101334 (12, 2229); Wards Fork, Roanoke Cr., below mill dam, between Madisonville and Cullen; Sept. 15, 1935. USNM $179847(1,38)$ holotype and CU 29992 (8, 30-38); trib. of Horsepen Cr., $2.4 \mathrm{mi}$. NW of Wylliesburg on Va. 607; March 31, 1956. CU 34544 (7, 29-40); Wards Fork Cr., $6.7 \mathrm{mi}$. SSW of Madisonville on Va. 47; Sept. 16, 1959. N.C.-Granville Co.: DU uncat. (1, 38); Beech Cr., 3 mi. NNE of Cornwall (this area now flooded by Kerr Dam); Spring 1952.

Eno-Neuse R., N.C.-Durham Co.: DU uncat. (5, 30-35); 4.5 mi. E Oak Grove, Lick Cr. on rt. 264; April 9, 1950. Orange Co.: DU uncat. (1, 36); Eno R. 2 mi.

TABLE 40.

Number of unpored lateral-line scales in the species of the subgenera Hololepis and Villora

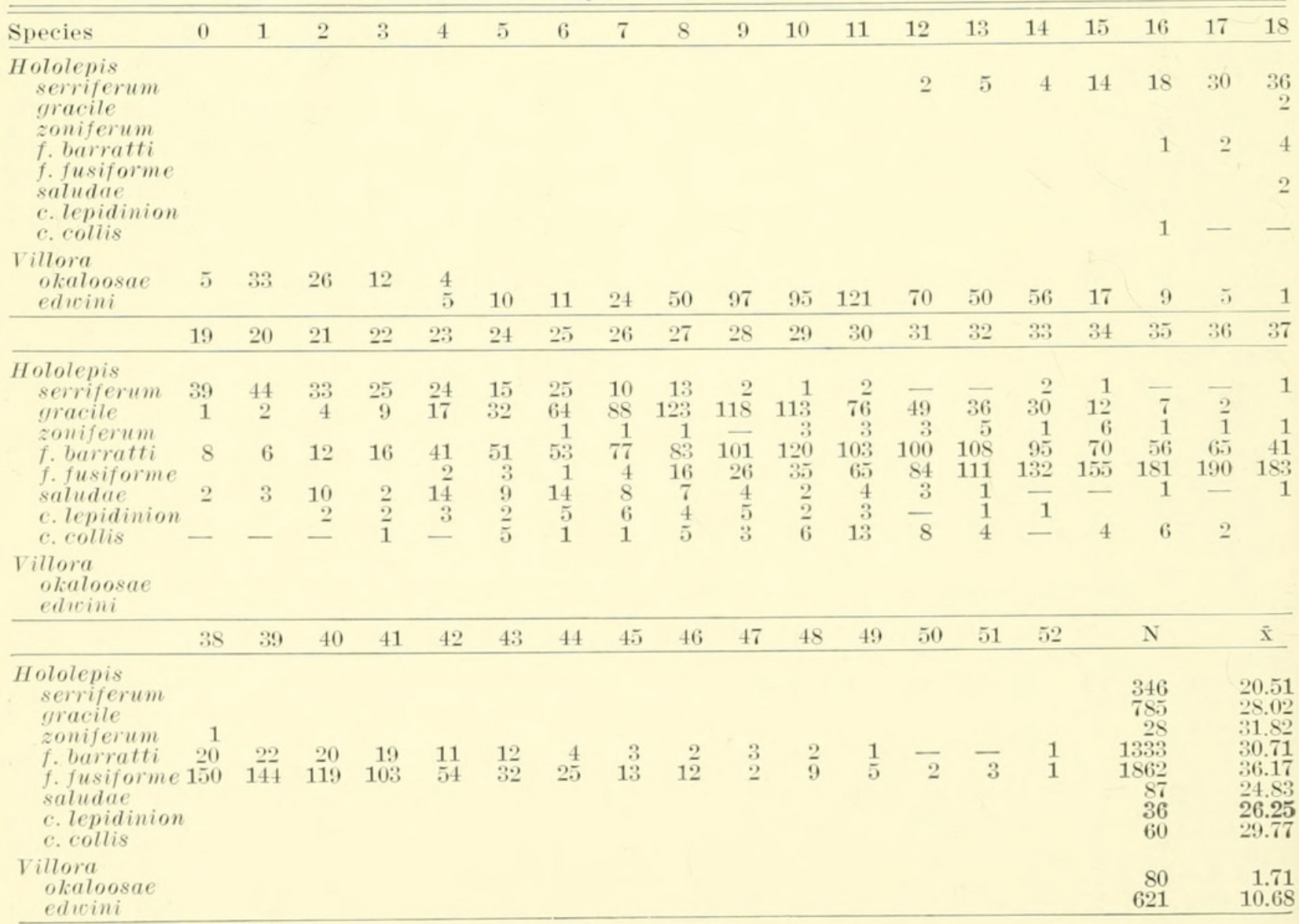



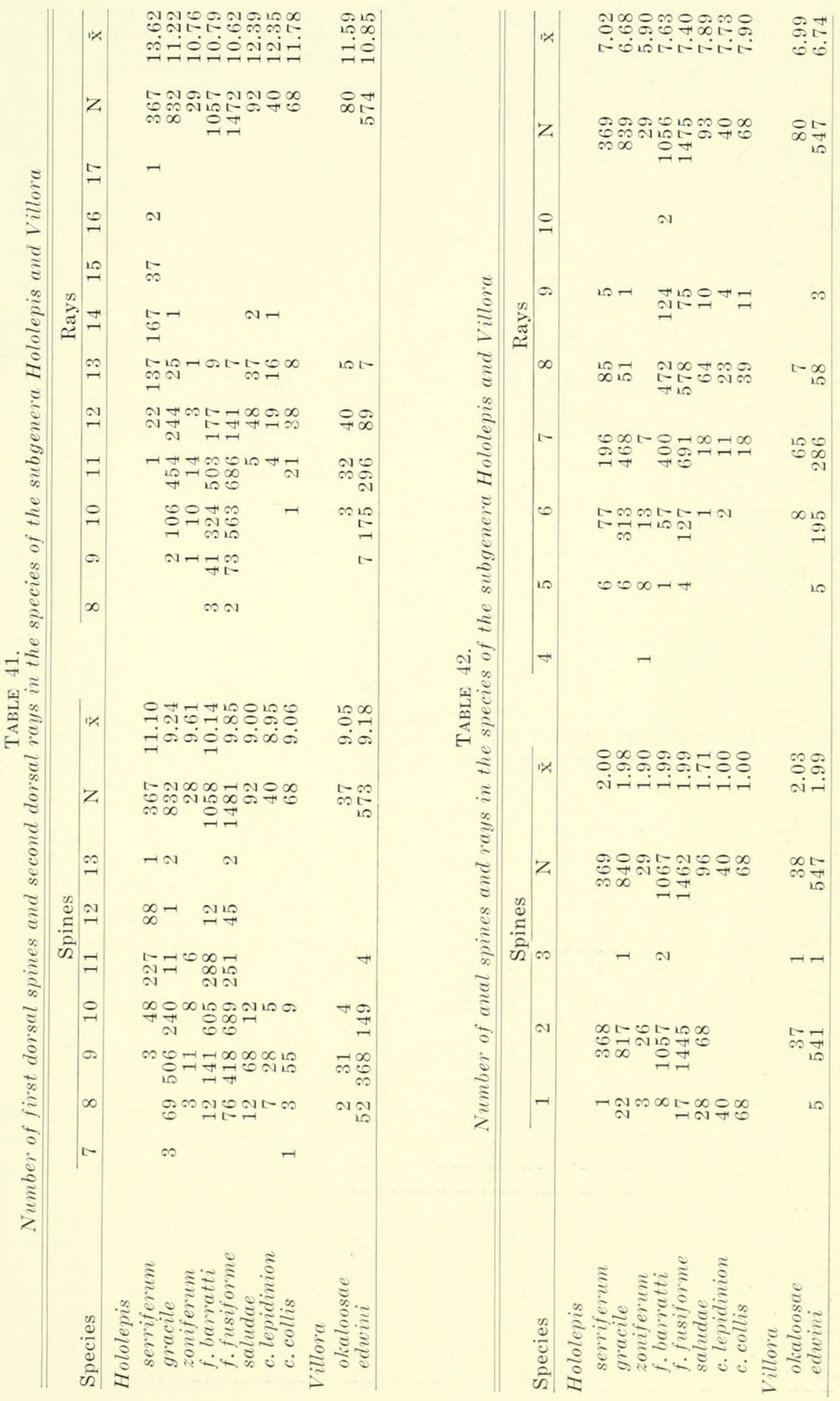
TABLE 43.

Number of scale rows above and below the lateral line in the species of the subgenera Hololepis and Villora.

\begin{tabular}{|c|c|c|c|c|c|c|c|c|c|c|c|c|c|}
\hline \multirow[b]{2}{*}{ Species } & \multicolumn{13}{|c|}{ Above the Lateral Line } \\
\hline & 2 & & 3 & & 4 & & 5 & & 6 & & & & $\overline{\mathrm{x}}$ \\
\hline \multicolumn{14}{|l|}{ Hololepis } \\
\hline serriferum & & & 17 & & 286 & & 55 & & & & & & 4.11 \\
\hline gracile & 3 & & 289 & & 453 & & 66 & & 1 & & 81 & & 3.72 \\
\hline zoniferum & & & 22 & & 7 & & & & & & & & 3.24 \\
\hline f. barratti & 157 & & 776 & & 100 & & & & & & 10 & & 2.94 \\
\hline f. fusiforme & 362 & & 1042 & & 48 & & 1 & & & & $14:$ & & 2.79 \\
\hline saludae & 25 & & 67 & & & & & & & & & & 2.73 \\
\hline c.lepidinion & 8 & & 30 & & 2 & & & & & & & 0 & 2.85 \\
\hline c. collis & 11 & & 44 & & 4 & & & & & & & 9 & 2.88 \\
\hline \multicolumn{14}{|l|}{ Villora } \\
\hline okaloosae & & & 10 & & 70 & & & & & & & & 3.88 \\
\hline \multirow[t]{2}{*}{ edwini } & 5 & & 304 & & 245 & & 8 & & & & & & 3.46 \\
\hline & \multicolumn{13}{|c|}{ Below the Lateral Line } \\
\hline Species & 5 & 6 & 7 & 8 & 9 & 10 & 11 & 12 & 13 & 14 & 15 & $\mathrm{~N}$ & $\overline{\mathrm{x}}$ \\
\hline \multicolumn{14}{|l|}{$\begin{array}{l}\text { Hololepis } \\
\text { serriferum }\end{array}$} \\
\hline serriferum & & & & & & 25 & 111 & 140 & 75 & 4 & 1 & 356 & $\begin{array}{r}11.79 \\
8.94\end{array}$ \\
\hline $\begin{array}{l}\text { gracile } \\
\text { zoniferum }\end{array}$ & & & 19 & $\begin{array}{r}238 \\
12\end{array}$ & 356 & 160 & 29 & 3 & & & & $\begin{array}{r}805 \\
29\end{array}$ & $\begin{array}{l}8.94 \\
8.24\end{array}$ \\
\hline $\begin{array}{l}\text { zoniferum } \\
\text { f. barratti }\end{array}$ & & & 61 & $\begin{array}{l}12 \\
286\end{array}$ & $\begin{array}{r}9 \\
456\end{array}$ & $200^{2}$ & 26 & 2 & & & & $\begin{array}{r}29 \\
1032\end{array}$ & $\begin{array}{l}0.24 \\
8.85\end{array}$ \\
\hline f. fusiforme & & 28 & 299 & 723 & 361 & 35 & 2 & 1 & & & & 1449 & 8.06 \\
\hline saludae & & 1 & 19 & 37 & 29 & 6 & & & & & & 92 & 8.22 \\
\hline c.lepidinion & & & 2 & 15 & 14 & 7 & 2 & & & & & 40 & 8.80 \\
\hline c. collis & & & 7 & 29 & 23 & 5 & 1 & & & & & 65 & 8.45 \\
\hline \multicolumn{14}{|l|}{ Villora } \\
\hline okaloosae & 5 & 74 & & & & & & & & & & 79 & 5.94 \\
\hline edwini & 7 & 150 & 246 & 114 & 36 & 8 & 1 & & & & & 562 & 7.09 \\
\hline
\end{tabular}

TABLE 44.

Number of branchiostegals and pectoral rays in the species of the subgenera Hololepis and Villora

\begin{tabular}{|c|c|c|c|c|c|c|c|c|}
\hline \multirow[b]{2}{*}{ Species } & \multicolumn{8}{|c|}{ Branchiostegals } \\
\hline & 5 & & 6 & & 7 & & & $\overline{\mathrm{x}}$ \\
\hline \multicolumn{9}{|l|}{ Hololepis } \\
\hline $\begin{array}{l}\text { serriferum } \\
\text { gracile }\end{array}$ & $\begin{array}{r}3 \\
10\end{array}$ & & $\begin{array}{l}138 \\
177\end{array}$ & & $\begin{array}{l}9 \\
8\end{array}$ & & & $\begin{array}{l}6.04 \\
5.99\end{array}$ \\
\hline $\begin{array}{l}\text { gracile } \\
\text { zoniferum }\end{array}$ & & & 11 & & 2 & & & 6.15 \\
\hline f. barratti & 15 & & 134 & & 4 & & & 5.93 \\
\hline f. fusiforme & 31 & & 150 & & 3 & & & 5.85 \\
\hline saludae. & 1 & & 30 & & 2 & & & 6.03 \\
\hline c. lepidinion & & & 30 & & 2 & & & 6.06 \\
\hline \multicolumn{9}{|l|}{ Villora } \\
\hline okaloosae & & & 10 & & & & & 6.00 \\
\hline \multirow{2}{*}{ edwini } & 1 & & 98 & & 7 & & & 6.06 \\
\hline & \multicolumn{8}{|c|}{ Pectoral Rays } \\
\hline Species & 10 & 11 & 12 & 13 & 14 & 15 & $\mathrm{~N}$ & $\overline{\mathrm{x}}$ \\
\hline \multicolumn{9}{|l|}{ Hololepis } \\
\hline $\begin{array}{l}\text { serriferum } \\
\text { gracile }\end{array}$ & & 13 & 118 & $\begin{array}{r}26 \\
158\end{array}$ & 13 & & $\begin{array}{l}157 \\
173\end{array}$ & $\begin{array}{l}12.08 \\
13.06\end{array}$ \\
\hline $\begin{array}{l}\text { gracile } \\
\text { zoniferum }\end{array}$ & & & 3 & 17 & $\begin{array}{r}10 \\
2\end{array}$ & 1 & 23 & 13.04 \\
\hline f. barratti & & & 26 & 125 & $4 \overline{7}$ & 11 & 209 & 13.21 \\
\hline f. fusiforme & & & 9 & 155 & 36 & 1 & 201 & 13.14 \\
\hline saludae & & 40 & 47 & & & & 87 & 11.54 \\
\hline c.lepidinion & & & 28 & 3 & & & 33 & 12.03 \\
\hline c. collis & 1 & $2 \overline{9}$ & 31 & 1 & & & 62 & 11.52 \\
\hline \multicolumn{9}{|l|}{ Villora } \\
\hline $\begin{array}{l}\text { okaloosae } \\
\text { edwini }\end{array}$ & & 2 & $\begin{array}{l}16 \\
45\end{array}$ & $\begin{array}{l}52 \\
91\end{array}$ & $\begin{array}{l}6 \\
3\end{array}$ & & $\begin{array}{r}74 \\
141\end{array}$ & $\begin{array}{l}12.86 \\
12.67\end{array}$ \\
\hline & & 2 & & & & & & 12.67 \\
\hline
\end{tabular}


TABLE 45.

Number of preoperculomandibular pores and interorbital pores in the species of the subgenera Hololepis and Villora

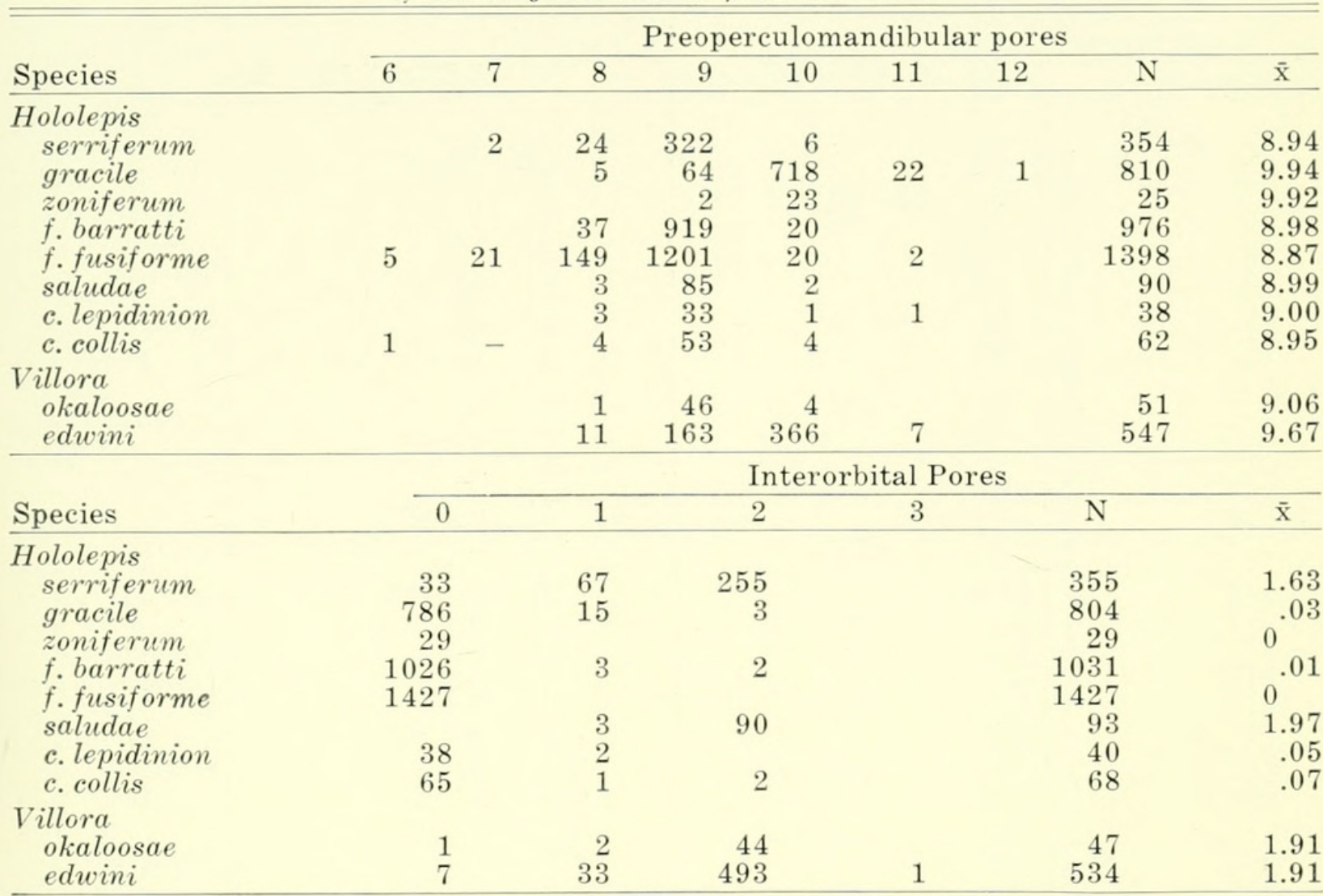

W of Hillsboro; March 20, 1949. DU uncat. $(1,38)$; Eno R. at ford $\mathrm{N}$ of Hillsboro near Skipper Wright's; April 21, 1955.

Cape Fear R., N.C.-Guilford Co.: CU 25187 (1, 20); Haw R., 3.5 mi. S of Stokesdale on rt. 68; June 24, 1946.

\section{Etheostoma collis collis}

(Hubbs and Cannon)

Hololepis collis-Hubbs and Cannon, 1935: 52-54, pl. I-III (original description); Fowler, 1940:40 (Santee R.); Randall, 1958: 342 (Piedmont of S. C., Catawba-Wateree R.).

Etheostoma collis-Bailey and Gosline, 1955: 20, 44 (number of vertebrae); Moore, 1957:198.

Etheostoma colle-Eddy, 1957: 220.

Etheostoma collis collis-Collette, 1961: 2051.

Types-Holotype, UMMZ 94560; 40 mm male; S. C., York Co., creek near York; Nov. 11, 1931; Donald Ameel, Paratypes, UMMZ 107085; same data as holotype and UMMZ 94546; S. C., York Co., Steele Cr., trib. to Catawba R., Rock Hill; Nov. 11, 1931, Donald Ameel.
Diagnosis - One anal spine (erroneously given as two on the types by Hubbs and Cannon, 1935:53); interorbital pores usually absent; usually (93\%) $1+3$ infraorbital pores; nape squamation usually less than $20 \%(\overline{\mathrm{x}}: 3 \%)$; breast naked. Maximum size of males $43.1 \mathrm{~mm} \mathrm{SL}$ (CU 31663, Rocky-Pee Dee R.), females 43.0 mm (CU 33052, Yadkin-Pee Dee R.).

Coloration-All the available collections contain specimens with at least a vestige of breeding color. There are no important differences between the breeding patterns of $E$. collis collis and E. collis lepidinion. There are probably few differences between the patterns of non-breeding individuals. Hubbs and Cannon's (1935) description of males taken in November indicated the breeding pattern. Breeding males do not have a red submarginal band in the first dorsal fin as postulated by Hubbs and Cannon (1935).

The breeding female has small melanophores scattered on the anterior spines, and has large and small melanophores on the posterior spines of the first dorsal fin. The second dorsal has rounded patches of me- 


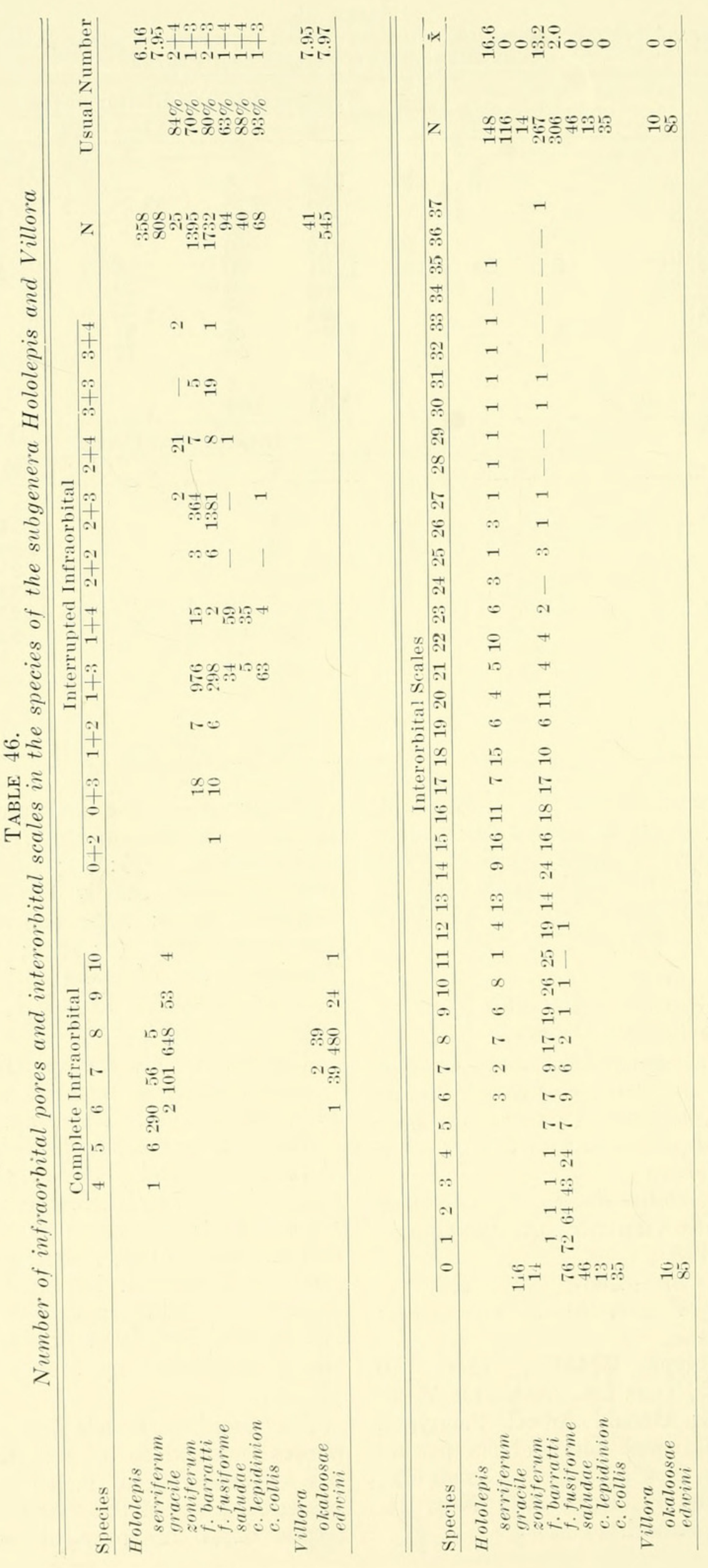


TABLE 47.

Supratemporal canal and coronal pore and condition of preopercle in the species of the subgenera Hololepis and Villora

\begin{tabular}{|c|c|c|c|c|}
\hline \multirow[b]{2}{*}{ Species } & \multicolumn{2}{|c|}{ Coronal Pore } & \multicolumn{2}{|c|}{ Supratemporal Canal } \\
\hline & Present & Absent & Complete & Incomplete \\
\hline \multicolumn{5}{|l|}{ Hololepis } \\
\hline serriferum & 47 & & 346 & 3 \\
\hline gracile & 455 & 2 & 715 & 48 \\
\hline zoniferum & 6 & & 8 & 21 \\
\hline f. barratti & 342 & 24 & 1201 & 84 \\
\hline f. fusiforme & 305 & 55 & 1047 & 122 \\
\hline saludae & 45 & & 41 & 53 \\
\hline c.lepidinion & 32 & & 15 & 24 \\
\hline c. collis & 37 & & 33 & 35 \\
\hline \multicolumn{5}{|l|}{ Villora } \\
\hline okaloosae & 46 & & 43 & 3 \\
\hline edwini & 259 & & 516 & 20 \\
\hline
\end{tabular}

Condition of Preopercle

\begin{tabular}{|c|c|c|c|c|}
\hline Species & Entire & Partly serrate & Serrate & $\mathrm{N}$ \\
\hline \multicolumn{5}{|l|}{ Hololepis } \\
\hline serriferum & & & 304 & 304 \\
\hline gracile & 772 & & & 772 \\
\hline zoniferum & 29 & & & 29 \\
\hline f. barratti & 900 & 515 & & 1414 \\
\hline f. fusiforme & 1620 & 194 & & 1814 \\
\hline saludae. & 96 & & & 96 \\
\hline c.lepidinion & 35 & 5 & & 40 \\
\hline c. collis & 68 & & & 68 \\
\hline \multicolumn{5}{|l|}{ Villora } \\
\hline okaloosae & 3 & $14^{*}$ & $28 *$ & 45 \\
\hline edwini & 518 & 2 & & 520 \\
\hline
\end{tabular}

* The preopercle is crenulate instead of serrate in E. okaloosae.

lanophores that iend to form bands across the fin. The anal fin is clear in most specimens, while others have concentrations of small melanophores. The pectoral fins of both males and females have melanophores on the rays The pelvic fin lacks melanophores. The caudal is barred. The breast, belly and lower sides lack melanophores. There are scattered large melanophores on the cheek. In both sexes there are usually three orbital bars present; suborbital, preorbital, and postorbital. The first two are the most prominent and some specimens lack the postorbital as well as the supraorbital. The pored portion of the lateral line stands out as a narrow light line although it may be interrupted by some pigment under the distal third of the scale. The median basi-caudal spot is the most prominent although it is diffuse in some specimens. The dorsal and ventral spots vary in intensity, and are sometimes almost as prominent as the median spot. Most females have variegated brown sides and lack lateral blotches. The genital papilla lacks pigment. The patterns of breed- ing females of E. collis collis, E. collis lepidinion and E. saludae are compared in Figure 17.

As in E. collis lepidinion, the breeding male is colored like the female, but darker in some regions. The membranes of the first dorsal fin are covered with small melanophores concentrated on the anterior three membranes. Some specimens have the first membrane almost entirely black. Four to five sets of quadrangular blotches give the second dorsal a banded appearance. The anal fin, belly and breast are uniformly covered with small melanophores. There are more small melanophores on the membranes than on the rays of the pelvic fin. The cheek has more melanophores than that of the female. Males usually have seven to eight lateral blotches which extend from the caudal base to the middle of the first dorsal fin. These blotches are more prominent in the smaller adults. There is pigment on the posterior ventral side of the genital papilla in large males. Some small specimens have a band of pigment encircling the papilla. A specimen 



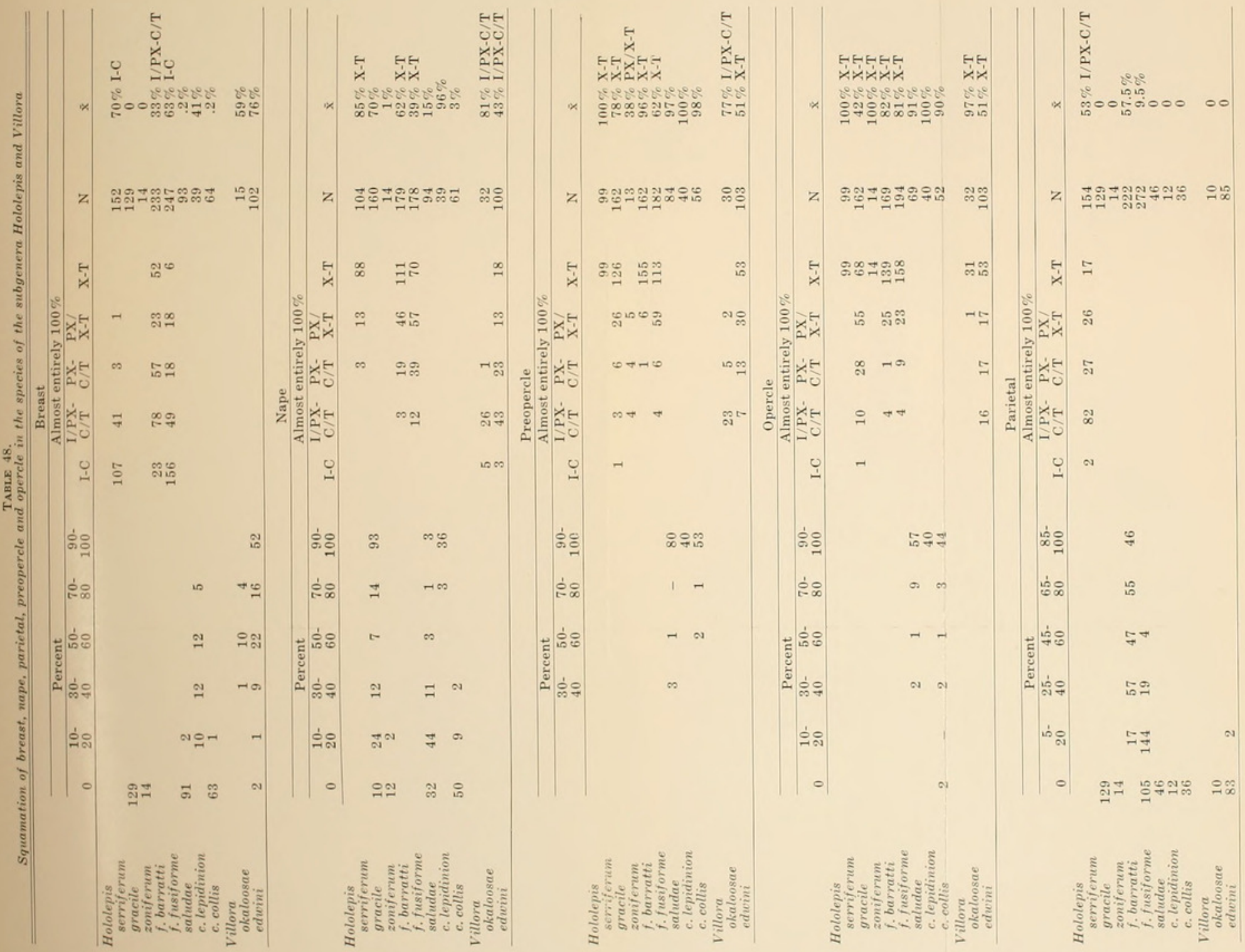



TABLE 49.

Number of vertebrae in the species of the subgenera Hololepis and Villora (based in part on data presented by Bailey and Gostine, 1955)

\begin{tabular}{|c|c|c|c|c|c|c|c|c|c|c|c|}
\hline Species & 33 & 34 & 35 & 36 & 37 & 38 & 39 & 40 & 41 & $\mathrm{~N}$ & $\overline{\mathrm{x}}$ \\
\hline \multicolumn{12}{|l|}{ Hololepis } \\
\hline serriferum & & & & & & 3 & & 7 & 1 & 25 & 39.24 \\
\hline gracile & & & & 4 & 15 & 13 & 2 & & & 34 & 37.38 \\
\hline zoniferum & & & & 1 & 3 & 4 & 2 & & & 10 & 37.70 \\
\hline f. barratti & & & & & 3 & 13 & $1 \overline{6}$ & 1 & & 33 & 38.45 \\
\hline f. fusiforme & & & & & 5 & 25 & 15 & 8 & & 53 & 38.49 \\
\hline saludae. & & & & 3 & & & & & & 3 & 36.00 \\
\hline c.lepidinion & & & 2 & 7 & 5 & 2 & & & & 16 & 36.44 \\
\hline c. collis & & & & 3 & 36.00 \\
\hline $\begin{array}{l}\text { Villora } \\
\text { okaloosae }\end{array}$ & 1 & 10 & 13 & 2 & & & & & & 26 & 34.62 \\
\hline edwini & & 1 & 3 & 4 & 10 & 3 & & & & 21 & 36.52 \\
\hline
\end{tabular}

as small as $27.4 \mathrm{~mm}$ has full breeding pigmentation and tubercles. A comparison of the breeding pattern of male E. collis collis, E. collis lepidinion and E. saludae is presented in Fig. 18.

Genital Papilla-The genital papilla of the breeding female is an elongate tube like that of E. fusiforme (Fig. 1f).

Breeding Tubercles-Present on the anal and pelvic fins of breeding males. Specimens taken on March 22 (CU 11988) have moderately large tubercles on the lower side of the pelvic spine and rays and on all the anal fin rays (Fig. $1 \mathrm{~g}$ ).

Habitat-Field notes for five late March collections (CU 29832, 29991, 31663, 31717,33052 ), show the habitat to be small to medium-sized streams, shore wooded or partly wooded and partly pasture, width 5-40 feet, depth 2-3 feet, current slow to moderate, aquatic vegetation absent, bottom sand, mud, or rubble covered with silt and/or detritus. All specimens were taken either in backwater pools or near stream banks in slow-moving water. Most of the specimens in one collection (CU 31663) were taken from the shallow water along the banks of a pool at a cattle crossing; here a number were resting in depressions made by cows' hoofs, sheltered from the current. In Waxhaw Creek Creek (CU 31717) three out of nine specimens were taken near the banks of the main stream over mud, while the other six were collected in a small backwater pool less than two feet wide.

Habits-Little is known of its habits. In the spring of 1958 , specimens from the Yadkin River were brought back alive to the laboratory. Although they survived a week-long collecting trip, they all died after being left in the laboratory for a few hours. Members of the E. collis-saludae complex live in the cooler and presumably more oxygenated waters of the Piedmont, so perhaps their oxygen requirements are higher than those of the lowland species of Hololepis, which are frequently taken in very warm stagnant situations. A few E. serriferum taken on this trip also died, but all the E. fusiforme fusiforme survived.

Courtship and spawning have not been observed. However, judging from the pigment pattern of the breeding males and the location of the breeding tubercles, it seems likely that the courtship patterns are similar to those of E. f. fusiforme (q.v.). Eggs were extruded by a female collected on March 31 (CU 31663) when held in my hand, confirming the evidence from the breeding tubercle development that the spawning season is near the end of March.

Distribution-Restricted to the Piedmont streams of North and South Carolina. Taken only in two tributaries of the Pee Dee River (the Rocky and Yadkin rivers) and in the Catawba-Wateree branch of the Santee River (Fig. 3). The holotype and one of the paratypes were listed from an indefinite locality between the Catawba and Broad rivers (part of the Congaree-Santee system) but it is felt that these specimens must have come from the Catawba because the Saluda-Broad is inhabited by the closely related E. saludae.

Specimens Examined-Yadkin-Pee Dee R., N. C. Davidson Co.: all collections from the same locality which is: trib. of Yadkin R., 0.4 mi. W jet NC 109 and sec. rd., $1 \mathrm{mi}$. N of Cid: UMMZ $138569(2,31-33):$ UMMZ $138568(1,39)$; and CU 11988 (12, 27-41); March 22, 1948. Also CU 29991 ( $7,31-38)$; March 30 , 1956 ; and CU $33052(9,33-43)$; March $30,1958$. 


\section{$2 \mathrm{BHL}$ Biodiversity Heritage Library}

Collette, Bruce B. 1962. "The swamp darters of the subgenus Hololepis (Pisces, Percidae)." Tulane studies in zoology 9, 115-211.

https://doi.org/10.5962/bhl.part.25183.

View This Item Online: https://www.biodiversitylibrary.org/item/28548

DOI: https://doi.org/10.5962/bhl.part.25183

Permalink: https://www.biodiversitylibrary.org/partpdf/25183

\section{Holding Institution}

Harvard University, Museum of Comparative Zoology, Ernst Mayr Library

\section{Sponsored by}

Harvard University, Museum of Comparative Zoology, Ernst Mayr Library

\section{Copyright \& Reuse}

Copyright Status: In copyright. Digitized with the permission of the rights holder.

Rights Holder: Tulane University

License: http://creativecommons.org/licenses/by-nc-sa/3.0/

Rights: https://biodiversitylibrary.org/permissions

This document was created from content at the Biodiversity Heritage Library, the world's largest open access digital library for biodiversity literature and archives. Visit BHL at https://www.biodiversitylibrary.org. 